Laura Jane McLeod

GENDER POLITICS

AND SECURITY

DISCOURSE

Feminist and Women's Organising in "Post-conflict" Serbia.

Thesis submitted for partial fulfilment of the degree of Doctorate of

Philosophy

Department of Politics, University of Sheffield: December 2010 


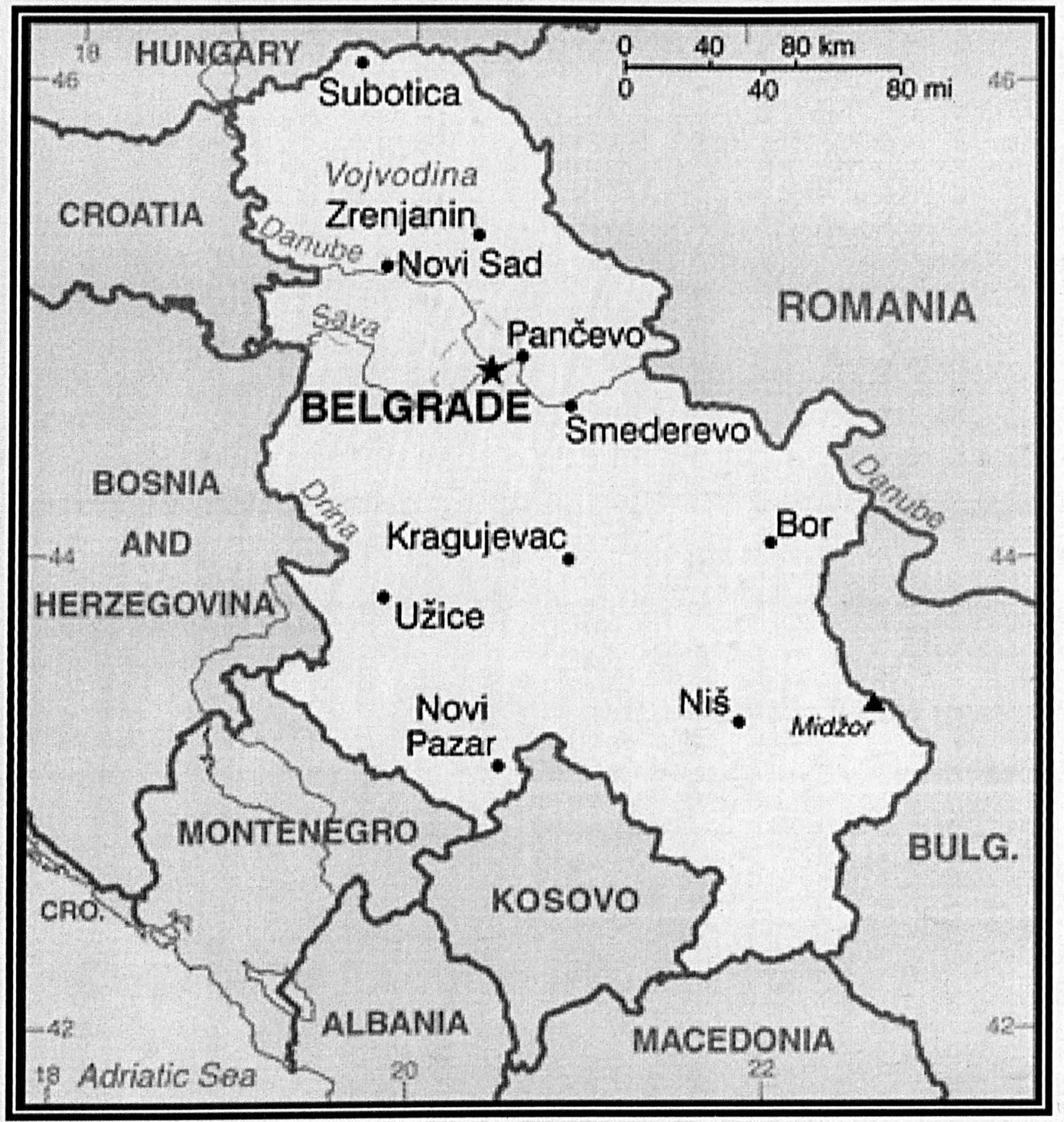

Map of Serbia: retrieved from

http://www.balkanology.com/serbia/ [accessed 11 March 2010].

UNIVERSIT:

OF SHEFFIEL

LIBRARY 
$\begin{array}{ll}\text { Acknowledgements } & 8\end{array}$

$\begin{array}{lr}\text { Abstract } & 10\end{array}$

Acronyms

List of illustrations and tables

$\begin{array}{lr}\text { INTRODUCTION } & 15\end{array}$

$\begin{array}{ll}\text { KEY THEMES } & 17\end{array}$

"Gender Security" as Discourse $\quad 18$

Destabilising "Post-Conflict"

Profiling Gender Politics

OUTLINE OF STUDY AND CASE STUDY SELECTION 34

$\begin{array}{ll}\text { ONTOLOGICAL MOMENTS } & 37\end{array}$

PART ONE: GENDER POLITICS AND SECURITY DISCOURSE. $\quad 41$

1. TRACING THE POLITICS OF "GENDER SECURITY".

FORMING AND INFORMING TEXTS

Ontology and Epistemology: Feminist Poststructuralism 44

Methodology 49

Multi-sited Ethnograpby $\quad 55$

ANALYTICAL STRAGETY (1): DISCOURSE $\quad 57$

Discourses about Discourse $\quad 58$

Components of Discourse $\quad 60$

Analysing Discourse $\quad 65$

ANALYTICAL STRAGETY (2): NARRATIVES AND TEMPORALITY 66

Thinking about Time and Temporality in IR 67

Temporality and Identity $\quad 69$ 
Temporal Moments

CONCLUSIONS

2. APPROACHES TO SECURITY.

SECURITY $=$ NATIONAL/STATE $\quad 79$

SECURITY $=$ INDIVDUAL/INTERNATIONAL $\quad 84$

Addition: Human Security Studies $\quad 84$

Reconceptualisation: Critical Security Studies $\quad 88$

Gendering Security $\quad 91$

SECURITY $=$ DISCURSIVE/PERFORMATIVE 94

Securitizing Security $\quad 95$

Performative and Signified Security $\quad 98$

Performance and Signification of Gender Security 101

$\begin{array}{lr}\text { CONCLUSIONS } & 103\end{array}$

3. PICKING THE PETALS: PROFILING GENDER POLITICS 105

$\begin{array}{ll}\text { FEMINISM AND COMMUNISM } & 106\end{array}$

Communist Practice and Women's Rights 107

The Yugoslavian Difference $\quad 110$

POLITICS, WAR AND INTERESTS $\quad 114$

Feminism and War: Coalitions $\quad 115$

Feminism and War: Divisions 119

THE WIND IN THE SAILS: DEMOCRATIC TRANSITION $\quad 126$

$\begin{array}{lc}\text { Strategy and Political Responsibility } & 127\end{array}$

$\begin{array}{ll}\text { Networks } & 131\end{array}$

CONCLUSIONS $\quad 135$

4. (RE)CONCEPTULISING SECURITY? 137

$\begin{array}{lr}\text { SECURITY AND POLITICS } & 138\end{array}$

Translating "Security" in and out of Serbian 139 
$\begin{array}{ll}\text { Security via (In) security } & 141\end{array}$

Temporality and "Security" 144

$\begin{array}{ll}\text { SIGNIFYING SECURITY } & 146\end{array}$

(1) Connection of Security with Human Rights 147

(2) Structural Logics of In/ security: Women-specific Security Concerns 151

(3) Insecurity following Transitions Affecting "Everyday Life"

TEMPORALITY AND (GENDER) SECURITY DISCOURSE 157

$\begin{array}{ll}\text { CONCLUSIONS AND LOOKING AHEAD } & 161\end{array}$

PART TWO: ARTICULATING AND REPRESENTING “GENDER SECURITY”. 164

5. A NEW PATCHWORK SQUARE: FEMINISM, PEACE, AND SECURITY. $\quad 165$

WOMEN IN BLACK AND THE FEMINIST PACIFIST DEBATE 166

$\begin{array}{ll}\text { Critiques of Militarism } & 168\end{array}$

$\begin{array}{ll}\text { Political Responsibility: The Postwar Problem } & 171\end{array}$

The Patchwork Blanket: Adding "Security" 174

LEARNING ABOUT/THROUGH “SECURITY” AND UNSCR 1325

'A Room of One's Own': Developing Notions of "Security" 177

The Discursive Moment: Stating Security 180

USING “SECURITY” AND UNSCR 1325

(1) The Draft Resolution: Localising Women, Peace, and Security 184

(2) The Women's Peace Coalition: Inclusion in Peace Processes 187

(3) Women's Human Rights Defenders: Voicing an Alternative 190

$\begin{array}{lr}\text { CONCLUSIONS } & 193\end{array}$

6. PULLING THE TRIGGER: GENDER, DOMESTIC VIOLENCE, AND SECURITY 195 GENDER POLITICS AND THE DOMESTIC VIOLENCE DEBATE(S) 197

Discursive Logics: (1) Transitions. $\quad 198$

Discursive Logics: (2) Institutions. 202

Pulling the Trigger: SALW and Domestic Violence 205 
INTERVENTION? INTERNATIONAL GENDER SECURITY DISCOURSE

International Human Security $\quad 210$

International Gender Mainstreaming 213

Making Discursive Contact: Gender, Security and Domestic Violence

USING “GENDER SECURITY”? $\quad 218$

Awareness-raising and Coalition-building $\quad 219$

Gender Politics and Security Discourse $\quad 222$

$\begin{array}{lr}\text { CONCLUSIONS } & 226\end{array}$

$\begin{array}{ll}\text { CONCLUSIONS. } & 228\end{array}$

GENDER SECURITY: COMPETING MODES OF THOUGHT

MAKING GENDER SECURITY POLICY $\quad 232$

IDENTIFYING "POST-CONFLICT” $\quad 235$

RETHINKING GENDER POLITICS $\quad 239$

$\begin{array}{lr}\text { APPENDIX [A]: FIELD RESEARCH } & 240\end{array}$

$\begin{array}{ll}\text { APPENDIX [B]: TABLE OF NGO INTERESTS AND RELATIONSHIPS } & 247\end{array}$

$\begin{array}{lr}\text { APPENDIX [C]: UNSCR } 1325 & 251\end{array}$

References 254 


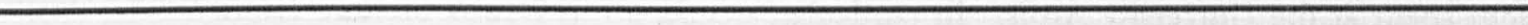




\section{ACKNOWLEDGEMENTS}

This $\mathrm{PhD}$ would not have been possible without the help of many people along the way. The Politics department at the University of Sheffield has been my intellectual home for eight years, first as an undergraduate, then as postgraduate. I wish to thank all academic and support staff - past and present - within the department for their assistance and encouragement. I am especially grateful for the unstinting support, guidance and understanding provided to me throughout my $\mathrm{PhD}$ by Georgina Waylen: I could not have asked for a better or more inspiring supervisor. Thanks are also due to Brian White who was an insightful and thoughtful second supervisor, and to Caroline Kennedy-Pipe (now at Hull), who encouraged me, as a final year undergraduate student, to consider undertaking a $\mathrm{PhD}$. Sarah Cooke, the departmental administrator, has proved to be a constant source of support, and countless thanks are due to her.

I also wish to thank my peers - too many to mention all individually - at Sheffield University not only for their friendship and academic insights but also for dodgy curries, The West Wing, coffee breaks and times spent at the University Arms. In particular, thanks go to Louisa Shilton, Laura White, Amy Barnes, Chris Kitchen, Adrian Gallagher, Defne Gurny, Rory Shand, Andrew Mumford, Craig Berry, Ben Richardson and David Moon. I am especially grateful to Asa Cussak, who I lived with for a year of genuine intellectual stimulation and fun. Torunn Eskedal and Jessica Baily both deserve a special mention for our enjoyable conversations and their insights about feminism, feminist organising, and doing research on feminist organisations. Thanks are due to Gary Rivett for not only reading drafts of my chapters four and six, but especially for our extended coffee breaks where we would frequently talk about poststructuralism, memory and history.

I owe a number of intellectual debts outside of Sheffield University. First, to Laura Shepherd whose work has not only been influential to me, but who also read a conference paper presented at ISA 2009 - later the basis of my chapter five - providing me with enormously insightful and encouraging comments. Parts of chapter five appear in the edited collection Making Gender, Making War: Violence, Militaries and Peacekeeping Pratices (Routledge, forthcoming). The stimulating comments by Erika Svedberg, Annica Kronsell and Maud Edwards helped me hone ideas that made its way into the final thesis. I would also like to give a special mention to Carole Spray who spent hours (literally) talking with me during a critical stage supporting me in thinking about the themes of my thesis. Michael Rossi, who carried out research in Serbia at the same time as me, continues to amaze me with his knowledge of Yugoslav history: I am grateful for his thoughts on my chapter three and parts of my introduction. I would also like to thank Maja Kovać, Jamie Munn, Dusan Radunović and Marsha Henry for their initial fieldwork support.

I carried out three research trips to Serbia: February - August 2008, June 2009, and September 2009, and in that time, accumulated a number of debts. Especially important to me are Adam Hardie, Aleksander Skundrić and Gordana Radanović, who all transcribed and translated my interviews and conducted my telephone calls for me in Serbia. Words cannot express how grateful I am for all their hard work - but they were all so much more than just my research assistants: I wish to thank them for all their time and support, but most of all, for their friendship. I would like to thank Kate Lawrence, Vojislav Gregorcić, Katarina Glinić and Predrag Obucina for making me feel so at home in Belgrade. My second trip to Serbia in June 2009 took an entirely unplanned and unexpected twist when I got appendicitis. The potential stress of having an emergency operation aboard was relieved by the wonderful staff at the Belmedic clinic, and especially the surgeon Dejan Jovanovic, who provided excellent care and attention. 
I am especially grateful to all the people who I interviewed: this thesis would have been far poorer without their important contributions. Thanks are due to Daša Duhaček, Lepa Mladjenović and Miloš Urošević for helping to connect me with so many people. Jennifer Carter, an intern at Women in Black between October 2008 and July 2009 deserves thanks for not only reading early drafts of my chapters three and five, but also for our very stimulating email conversations about UNSCR 1325 and gender security: her curiosity and insight has been a source of enjoyment and support for me. Finally, a huge bvala goes to all of the people who allowed me to interview them - I can only hope that this thesis does your wonderful work justice.

A few very special mentions: these people in particular endured all my trials and tribulations in the research and writing of this thesis. I wish to thank Catherine Prichard for her life-long friendship and support, and for being such a willing companion for holidays to Eastern and South-Eastern Europe, allowing my interest in the region to grow. Second, thanks are due to my sister, Ellen McLeod, who had the (mis) fortune of living with me during my writing-up period. I consider myself lucky to have had the opportunity to live with her again as an adult. Finally, but most certainly not least, I would like to thank my partner, Shadi Al-Baba, who encouraged me to stay focussed when the going got tough, but reminded me when it was time to relax.

There was a time that it was not thought possible that I would - or could - go to university: as late as the 1980s, the myth of "Deaf and Dumb" still prevailed. There were a number of people who ignored that myth, and - against all odds - persevered in teaching me to communicate and supporting me throughout mainstream education. They are my hearing support teacher Lynne Donnelly, my learning support assistants Denise Thomas and Anita Whittaker, and my parents Jenny and John McLeod. Unquestionably, I would not have got this $\mathrm{PhD}$ without their belief in me over the past 26 years, and therefore I wish to dedicate this thesis to them. 


\section{ABSTRACT.}

Since the United Nations Security Council adopted UNSCR 1325 on Women, Peace and Security in October 2000, there have been debates about how to achieve "gender security". This thesis explores competing modes of constructions about "gender security" within feminist and women's NGOs in Serbia, highlighting the ways that personal-political imaginations of Serbia's conflict and post-conflict pasts, presents and futures affect the logics of "gender security".

Part one explores the configurations of "gender security" amongst feminist and women's NGOs in Serbia. Post-structural discourse analysis strategies are deployed to investigate the personal-political imaginations of conflict and post-conflict constituting how feminism and security is thought about. Utilising field research conducted in Serbia during 2008 and 2009, the discursive construction of competing modes of thought about gender and/or security amongst activists is revealed, highlighting that the way that conflict and post-conflict is thought about profoundly affects these modes of thought.

Part two is an in-depth examination of the performance of UNSCR 1325 within two case studies. UNSCR 1325 is taken to be the site of discursive contact between gender and security, and is productive of the articulation and representation of gender security policies and agendas. The first case study centres upon the feminist-pacifist debate, focussing upon Women in Black. UNSCR 1325 is utilised as a political tool to support the advocacy work of Women in Black. In contrast, the second case study explores ways specific discourses of gender security has stimulated political action. An investigation of the broader domestic violence debate in Serbia makes clear how international gender security discourses triggered an increasing concern about small arms and light weapons (SALW) abuse within domestic violence. Subsequently, activists have pushed SALW concerns higher up the domestic violence agenda in Serbia. The variations in how UNSCR 1325 is utilised is a consequence of the particular configuration of gender security, arising from personal-political imaginations of conflict and post-conflict amongst activists. 


\begin{tabular}{|c|c|}
\hline$\overline{\mathrm{AZZC}}$ & Autonomous Women's Centre \\
\hline BFPE & Belgrade Fund for Political Excellence \\
\hline $\mathrm{CDA}$ & Critical Discourse Analysis \\
\hline CEDAW & Convention on the Elimination of all Forms of Discrimination against Women \\
\hline CSS & Critical Security Studies \\
\hline$\overline{\mathrm{DDR}}$ & Disarmament, Demobilization, and Reintegration \\
\hline$\overline{\mathrm{DPT}}$ & Democratic Peace Theory \\
\hline EU & European Union \\
\hline FSS & Feminist Security Studies \\
\hline IANSA & International Action Network on Small Arms \\
\hline ICTY & International Criminal Tribunal for former Yugoslavia \\
\hline ITC & Incest Trauma Centre \\
\hline INGO & International Non-governmental Organisation \\
\hline IR & International Relations \\
\hline KFOR & Kosovo Force \\
\hline NAP & National Action Plan \\
\hline NATO & North Atlantic Treat Organisation \\
\hline NGO & Non-governmental Organisation \\
\hline OSÇE & Organisation for Security and Cooperation in Europe \\
\hline PoA & $\begin{array}{l}\text { Programme of Action to Prevent, Combat and Eradicate the Illicit Trade in } \\
\text { Small Arms and Light Weapons }\end{array}$ \\
\hline $\mathrm{RCC}$ & Regional Cooperation Council \\
\hline $\mathrm{RŹF}$ & Reconstruction Women's Fund \\
\hline SPSEE & Stability Pact for South-Eastern Europe \\
\hline SRS & Serbian Radical Party \\
\hline SALW & Small Arms and Light Weapons \\
\hline
\end{tabular}




\begin{tabular}{|c|c|}
\hline SEESAC & South-Eastern Europe Small Arms Clearinghouse \\
\hline$\overline{\mathrm{UN}}$ & United Nations \\
\hline UNDP & United Nations Development Programme \\
\hline UNDEF & United Nations Democracy Fund \\
\hline UNIFEM & United Nations Development Fund for Women \\
\hline UNMIK & United Nations Mission in Kosovo \\
\hline UNSCR 1244 & $\begin{array}{l}\text { United Nations Security Council Resolution } 1244 \text { (Establishes the presence of } \\
\text { UNMIK) }\end{array}$ \\
\hline UNSCR 1325 & $\begin{array}{l}\text { United Nations Security Council Resolution } 1325 \text { on Women, Peace, and } \\
\text { Security. }\end{array}$ \\
\hline UNSCR 1820 & $\begin{array}{l}\text { United Nations Security Council Resolution } 1820 \text { on Women, Peace, and } \\
\text { Security. }\end{array}$ \\
\hline UNSCR 1888 & $\begin{array}{l}\text { United Nations Security Council Resolution } 1888 \text { on Women, Peace, and } \\
\text { Security. }\end{array}$ \\
\hline UNSCR 1889 & $\begin{array}{l}\text { United Nations Security Council Resolution } 1889 \text { on Women, Peace, and } \\
\text { Security. }\end{array}$ \\
\hline$\overline{\mathrm{US}}$ & United States \\
\hline USSR & Union of Soviet Socialist Republics \\
\hline WPC & Women's Peace Coalition \\
\hline YUCOM & Lawyers Committee for Human Rights \\
\hline
\end{tabular}




\section{LIST OF ILLUSTRATIONS AND TABLES}

\section{ILLUSTRATIONS}

Image 3.1 Members of Obraz protesting during a public performance by Women in Black, 10 July 2009. 116

Image 3.2 Members of Women in Black at a network meeting, 7 June 2009.

Image 3.3 International Women's Day parade, 8 March 2010.

Image 4.1 Member of Women in Black bolding a banner marked "Security".

Image 5.1 Women in Black autivist bolding a banner marked "Antimilitarisation".

Image 6.1 Cover of report Firearms Possession and Domestic Violence in the Western Balkans:

\section{TABLES}

Figure 3.1 Spectrum of Attitudes towards feminism within Serbian women's and feminist organisations. 117

Appendix A Recorded interviews conducted.

Appendix B NGO Interests and Relationships. 


\section{INTRODUCTION.}

Sead Biberovic, an activist in Novi Pazar, south-west Serbia is laughing. I have asked him what "security" means to him. He tells me that "security" is "quite a contemporary topic ... it's become popular in the non-governmental organisation (NGO) sector: suddenly I'm receiving many emails on that particular topic'.' He apologises for laughing, and explains that he is sometimes bemused by the growth of "security" as a buzzword, in part because after Slobodan Milošević, the president of Serbia during the 1990s, fell from power in October 2000, Sead's personal security has improved. No longer does Sead fear passing a policeman in the street: during the $1990 \mathrm{~s}$, 'the police could do whatever they wanted, and not be sanctioned because of it', and hence 'we felt very high insecurity... we were afraid to pass near policemen in case of being beaten up'. ${ }^{2}$ Then he suddenly pauses, lost in thought, and frowns, before admitting that he feels disappointed that the state and government have not made many of the changes which he deems necessary to break away from the policies and violence of the $1990 \mathrm{~s}$. As a consequence, 'in almost eight years, there hasn't been a serious attempt by the government to reform the secret services and secret police, who are acting [in] almost the same [way] as during the time of Slobodan Miloševic'." In a way, the October 2000 "revolution" in Serbia has resolved old insecurities, but some insecurities remain, while others are new and renewed.

Many feminists in Serbia draw attention to ways in which violence and intolerance have remained embedded in Serbian society even after the apparent end of war policies with the transition to democracy in October 2000. As Cynthia Enloe points out, wars do not just "end": the same notion applies to the impacts of war policies, nationalism and political violence. ${ }^{4}$ Boban Stojanovic, a feminist activist in Belgrade, explains this colourfully through two very everyday stories;

'The other day, I went into the pet shop for catfood, and the saleswomen [examined] a list in a catalogue, and she says: "You can see this, it's good, there is some food recently bought by

1. Legija's ${ }^{5}$ daughter!". After that, I wondered what sort of society recommends something which

\footnotetext{
1 Interview, Sead Biberović, Coordinator of Urban-In, Novi Pazar, 18 july 2008. Further details about each interview (including the language that the interview was conducted in) are in appendix A. Key dctails of each organisation mentioned in this thesis are in Appendix B.

2 Ibid.

${ }^{3}$ Ibid.

4 C. Enloe The Morning Afker. Sexwal Politics at the End of the Cold War: (University of Califomia Press, Berkeley, 1993), p. 2.

5 Jegija is the nickname of the Scrbian criminal, Milorad Lllomek, who was a commander in the noterions sierbatn paramilitary group "Arkan's Tigers" fighting in Croatia and Bosnia during the 199/s. Ife was also behind the assassination of the centre-kft Prime Minister Dindjic in March 20013.
} 
[is used by] Legilja's daughter? This is one example of how I live in a deeply criminalised society'. ${ }^{6}$

'If someone attacks a gay man [for being gay], and I go to the police to report that, a police officer will say "well he [the victim] shouldn't wear tight jeans". I want the police officer to write down my statement, to call the witnesses and process it, and not comment on whether the guy shakes his ass or not. It is not the police officer's business. We have to change the system of values and to redefine who exists for whom in this society. ${ }^{7}$

Critically, in both stories, Boban insists that it is important to redefine social and political values in Serbia: it is the structural logics of what is being said that is problematic. Towards the end of 2009, the centre-left President of Serbia, Boris Tadić, begun to vocalise a need to address violence and fascism in Serbia, stating that he saw 'an unbroken thread between the violence of the Nineties, the monstrous crime in the former Yugoslavia, the political language that voices its fury against so-called traitors and the constant search for enemies in society', The rhetoric in Tadić's speech of October 2009 echoes much of the feminist-pacifist discourse in Serbia linking the contemporary culture of violence to the events and policies of the nationalist wars that occurred during the 1990s.

These anecdotes highlight that questions remain about the direction of Serbia's post-conflict reconstruction: questions which are linked to notions of gender security. This thesis explores how attitudes about feminism and post-conflict reconstruction in Serbia has shaped the precise configuration of "gender security" amongst activists of feminist and women's organisations. "Gender security" is contested because there are competing ideas about what constitutes gender, and security. These debates are examined later: chapter two explores varying ontological logics underpinning "security", while chapter three illuminates the visions about gender held by activists of feminist and women's organisations in Serbia. While the notion that gender security means attempting to make people feel safe from gender-related violence is not under any doubt; questions remain around what gender is, what gender-related violence is, what - and who - we need to feel safe

\footnotetext{
- Boban Stojanović speaking at a conference on Women, peace and Security: Resolution 1325 on 31 October 2008. Published as "Ženc, mir, bezbednost: Rezolucija 1325, 30 i 31 oktobar 2008' [Women, Pcace, Security: Resolution 1325, 30 - 31 October 2008] in Zene $z^{a}$ mir [Women for Peace] (Women in Black, Belgrade, 2009), p. 232. My own translation from the original Serbian: Jute sam otisao da kupim grebulicu

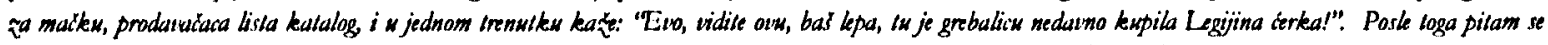

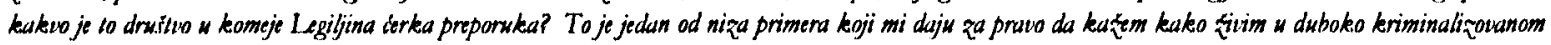
druitix. Except where specifically stated, all written materials eited in this thesis have been translated from Serbian into English by the NGOs.
}

\footnotetext{
7 Interview, Boban Stojanović, Belgrade, 11 April 2008. It is considered "gay" in Serbia for a male to wear tight jeans. Homosexual men have been violently attacked: an issue that came to very public attention in Scrbia during September 2009, when lesbian, gay, bisexual and transgender (LGBT) activists attempted to hold the second Belgrade Gay Pride Parade. Once the exact date of the Pride was revealed, threats towards LGBT people intensified, with posters by the far-right fascist organization 1385 plastered all over central Belgrade stating that "we're coming to get you".

- B92 'Tadić bemoans "unbroken thread of violence"' October 12009 retrieved hetpi//www b22 2net/cng/ncivi/politics [accessed 1 October 2009]. B92 is a popular and respected independent news agency in Serbia, with a 24 hour rolling news and current affairs television channel, a radio station and an online newspaper. The news agency established itself during the $1990 \mathrm{~s}$ as an independent source of news that was not controlled by Milošević, and was an important source of resistance. See M. Collin This is Senbia Calling: Rock 'n' Roll Radio and Belgrade's Underground Resistance (Serpent's Tail, London, 2004) for a readable account of B92 during the 1990s.
} 
from, and how to achieve "gender security". Gender security discourse, as noted in the opening anecdote from Sead, has become a buzzword, in part because of increasing international attention being paid to the notion that we should achieve gender security - whatever "gender security" looks like.

Important to this thesis is the notion that discourses of "gender security" have international, national, local and personal impacts. Hence, this thesis is not just a study of feminist and women's organising in Serbia during the noughties. It is also an investigation of how international security discourses have shaped the contours of feminist and women's organising in Serbia; an examination of the ways interpretations about "post-conflict" and "post-conflict reconstruction" have affected perceptions about "security" amongst gender activists in Serbia; and explores how attitudes about gender, feminism, and post-conflict intersect, affecting the framing of gender security discourse in Serbia. The study does not assume that actors are deliberately articulating "gender security", but rather, demonstrates some of the ways in which the international discourse of "gender security" has affected the agendas and actions of feminist and women's organisations in ways that may not be immediately apparent. This means that rather than adapting an approach which assumes 'the existence of certain social structures or rules, as well as the assumptions of the dominant theories of such reality', this study investigates how "security" is constituted, constructed or came about in relation to the postconflict reconstruction objectives of activists from feminist and women's NGOs in Serbia.9 I argue that "gender security" is a discourse constituted through particular and multiple personal-political imaginations embedded within a configuration of post-conflict.

\section{KEY THEMES}

The guiding research objective of this study is to make sense of how feminist and women's orgąnisations in Serbia have configured gender security discourse, and in particular, to examine the effects that personal-political imaginations of war, conflict and post-conflict reconstruction upon these discourses of gender security. These objectives are motivated by three overlapping themes and ideas. The first is the notion that "gender security" is a discourse, and therefore how "gender security" is conceptualised is profoundly political. The second key idea is that "post-conflict" is a problematic perception to pin down, especially in Serbia. Finally, the notion of "gender politics" is critical. "Gender politics" refers to the political profile of feminist and women's activists in relation to how they conceive of gender and feminism. Analysis in this thesis argues that the gender security discourse adapted by activists of feminist and women's organisations in Serbia is shaped by gender

9. Glynos and D. Howarth Logics of Critical Explanalion in Social and Political Theory (Routledge, London, 2007), p. 167. 
politics which are, in part, crafted by personal-political imaginations of war, conflict and post-conflict reconstruction in Serbia.

The three themes and ideas motivating the research objective of this study are driven by poststructural frameworks of problematisation. Adopting Jason Glynos and David Howarth's formulation of a problem-driven approach to social and political analysis, this thesis is primarily a 'movement of critical analysis in which one tries to see how the different solutions to a problem have been constructed; but also how these different solutions result from a specific form of problematization'.10 This approach recognises an 'ethos of political criticism' which 'involves an intervention or series of interventions in established modes of thought and action[s]... [involving] an effort to disturb those practices [being critiqued], and render as produced that which claims to be naturally emergent'." A critique is not the same as negative criticism. Essentially, the aim is 'to show bow something is what it is rather than what it means (or why it is what it is)', in order to 'direct our attention away from a preoccupation with a search for the cause or origin of something, and focus instead on the political consequences and effects of particular representations and how they came to be'.12 Hence, the research objective posed within this thesis aims to reveal the extent and ways in which gender security discourse impact upon the actions of feminist and women's organisations in Serbia.

\section{Gender Security as Discourse}

Central to this study is a concern with security discourse in relation to the political and social contexts in which the discourse functions. There are two premises arising from this concern. First: the perception that "security" is a discourse, and because "security" is a discourse, it can be made up of multiple meanings and can be thought about in different ways. This point is well illustrated by Michael Dillon in his seminal study on the politics of security;

'Security impresses itself as a kind of floating and radically inter-textual signifier which, by constant reference to all other signs of the times, transgresses disciplinary, political, corporeal and geographic boundaries as it courses through the defining technologically inspired discourses of Modernity: state security; national security; political security; global security; regional security; territorial security; economic security; financial security; individual security; collective security; personal security; physical security; psychological security; sexual security; social security; environmental security; food security......13

\footnotetext{
${ }^{10}$ Foucault, cited in J. Glynos and D. Howarth Logics of Critical Explanation in Social and Political Theory (Routledge, London, 2007 ), p. 167.

"D. Campbell Nutional Deconstruction: Violence, Identity, and Justice in Basnia (University of Minnesota Press, Minneapolis, 1998), p. 4.

12 Campbell National Deconstruction, p. 5.

${ }^{13}$ M. Dillion Politics of Security: Towards a Political Philosophy of Continental Thought (Routledge, London, 1996), p. 16.
} 
The primary conceptualisation of "security" discussed in this study is gender security: this thesis examines competing modes of thought about "gender security", highlighting how the discourse is thought about in different ways. The second premise relates to the notion that security discourse is performed in relation to the political and social contexts in which the discourse functions. This insight reveals that a discourse does not exist independently of its context: a discourse is in constant interaction with other discourses within a set of particular and specific temporal and spatial contexts. Together, the notion that security discourse relates to; functions within; and is constituted by; the broader social and political world highlights an important principle: the specific performance of security is inherently political. The understanding that security discourse is political recognises that actors can make choices which can affect the representation of "security"; that actors can exploit the opportunities arising from a specific security discourse; but also, that security discourse works to limit the frameworks through which activists operate.

As noted by Maria Stern in her study of Mayan women's perceptions of insecurity in Guatemala, most poststructural texts critiquing security tend to focus upon dominant and elite security discourses, rather than notions of gender security. ${ }^{14}$ Arguably, dominant representations of "security" rest upon assumptions of state sovereignty and power, frequently practiced by political elites who reinforce particular configurations of threats and dangers to state sovereignty. In contrast, "gender" concerns are frequently thought of as marginalised, and as such, "gender security" is posited as marginalised in a curious mixture of sites and arenas claiming political authority over the achievement of "gender security": from feminist NGO activists, to the UN system. The feminist concern guiding this thesis stresses the political and social importance of knowledges and practices often thought of as 'everyday' concerns. As such, one aim of the study is to apply discourse analysis methodologies to a range of less politically conspicuous events which illustrate the daily practices of reproduction and transformation'. ${ }^{15}$ This thesis takes the starting point that the concept of security is, in some arenas at least, beginning to take on a gender dimension in the practice of international politics. Although the constitution of gender security is imperfect and problematic, it is important to realise that the UN bas begun to connect "gender" and "security". The most significant site where discourses about gender and security make contact within the UN system is within United Nations Security Council Resolution 1325 (UNSCR 1325) on Women, Peace and Security. With the introduction of further resolutions concerned with Women, Peace and Security: UNSCR 1820, 1888 and 1889, it would appear that the principle of gender security is becoming enshrined within the UN system.

\footnotetext{
${ }^{14} \mathrm{M}$. Stern 'Racism, sexism, classism, and much more: reading security-identity in marginalized sites' in B. A. Ackerly, M. Stern, and J. True Feminist Metbodologies for Intemational Relations (Cambridge University Press, Cambridge, 2006), p. 182.

15 L. Hansen Security As Practice: Discourse Analysis and the Bastian W'ar (Routledge, London, 2006), p. 78.
} 
UNSCR 1325 was passed by the Security Council on 31 October 2000, urging for a gender perspective within UN peacekeeping and post-conflict processes. The Resolution was designed to affect the organisational arrangement of the UN system. ${ }^{16}$ The opening ten paragraphs that make up the preamble cite normative standards and goals already existing within international legal principles and political agreements, including the Beijing Declaration and Platform for Action, humanitarian and human rights law, and mine clearance and mine awareness programmes. ${ }^{17}$ These normative goals are specified to highlight and emphasise the need for a gender perspective within already existing conventions. The eighteen operational points following the preamble relates to the mandate of the UN Security Council. ${ }^{18}$ These provisions emphasise the need to achieve gender mainstreaming in all parts of the post-conflict process that the UN Security Council is involved in, urging for increased representation of women in the prevention, management and resolution of conflict, including $\mathrm{UN}$ peacekeeping and field operations. ${ }^{19}$ UNSCR 1325 also encourages training about, and consideration of, gender impacts in relation to conflict and post-conflict management, and encourages UN missions to consult with local and international women's groups. Additionally, the Resolution highlights some normative goals relating to the need to eliminate gender-based violence, including rape and sexual violence.

The success of UNSCR 1325 as a gender mainstreaming tool has been, and continues to be, widely debated by feminist scholars, and is rapidly becoming an important concern for feminist international relations. ${ }^{20}$ Scholars including Natalie Florea Hudson, Carol Cohn, Sheri Gibbings, Helen Kinsella, and Christine Sylvester point to the resolution as a radical document with the potential to have a significant impact upon the UN system and how we conceive of "security".,2 Others suggest that

16 E. Rehn and E. J. Sirieal Women, War and Peace; The Independent Experts' Assessment on the Impact of Armed Conflict on Women and Women's Role in Peace-building (United Nations Development Fund for Women (UNIFEM), New York, 2002), p. 3.

17 United Nations Security Council Resolution 1325 (UNSCR 1325) 31 October 2000; S/RES/1325 (2000). All Security Council resolutions can be retrieved from wwwewo.urg/Jucumonts [accessed $08 \mathrm{March} 2010$ ]. Unless a specific article is referred to, UNSCR 1325 will not be cited in the footnotes again in this thesis.

18 F. Hill 'How and When has Security Council Resolution 1325 (2000) on Women, Peace and Security Impacted Negotiations Outside the Security Council' Unpublished Master Thesis, Uppsala University Programme of Intemational Studies, 2004 - 2005 , p. 1 - 2.

19 Rehn and Sirleaf, Women, War and Peace, p. 3.

${ }^{20} \mathrm{~K}$. Hutchings '1988 and 1998: Contrast and Continuity in Feminist International Relations' Millennium: Joumal of Intemational Siudies, Vol. 37, No. 1, p. 103

21 C. Cohn 'Feminist Peacemaking: In Resolution 1325, The United Nations Requires the Inclusion of Women in All Peace Planning and Negotiation' Tbe Women's Reties of Bonks, Vol. 21, No. 5, (2004), pp. 8 - 9; C. Cohn, H. Kinsella, and S. Gibbings, Women, Peace and Security: Resolution 1325' Intemational Feminist Joumal of Politics, Vol. 6, No. 1, (2004) pp. 130 - 140; C. Cohn 'Mainstreaming Gender in UN Sccurity Policy: A Path to Political Transformation?' in S. M. Rai and G. Waylen (eds.) Global Gouemance: Feminist Perspectives (Palgrave, London, 2008), pp. 185 - 206; C. Sylvester 'Review of L. J. Shepherd Gender, Violence and Security: Discourse as Practice' Minenta: Jourmal of Women and War Vol. 3, No. 1 (2009), pp. 94 - 96; N. Florea Hudson Gender, Human Security and the United Nations: Security Langmage as a Political Framenork for Women (Routledge, London, 2009). 
UNSCR 1325 is problematic. Amy Barrow argues that the resolution 'seems overwhelmingly external to the internal dynamics of individual countries, which leads to the question of whether generic mainstreaming tools can be effectively applied in conflict prevention, resolution and reconstruction mechanisms', while Laura Shepherd highlights ways in which the constitution of (gender) violence and (international) security act to restrain the possibilities of UNSCR $1325.22 \mathrm{Nadje} \mathrm{Al-Ali}$ and Nicola Pratt, in their investigation of women in occupied Iraq, argue that the assumptions of UNSCR 1325 'are rendered hollow by the security concerns of the United States and its allies, the competing political agendas of different Iraqi politicians, and the fact that not all women support the same agenda'.23 Most of these works present UNSCR 1325 as an expression of a growing international norm about the need to protect gender rights within the post-conflict process. ${ }^{24}$ UNSCR 1325 in this thesis is recognised as a document initially designed to achieve gender mainstreaming within UN missions and structures, but has since had (sometimes unexpected and unknown) consequences for civil society activism in post-conflict zones, in part because the Resolution has acted as a site of discursive contact between gender, peace, and security.

UNSCR 1325 was the tip of the iceberg. Since then, there have been a further three Security Council resolutions dealing specifically with Women, Peace and Security. UNSCR 1820, passed 18 June 2008, highlights sexual violence in war and post-conflict as a source of insecurity, and reasserts that rape and other forms of sexual violence constitutes a war crime and a crime against humanity. ${ }^{25}$ UNSCR 1888, passed 30 September 2009, also has its emphasis upon the importance of acting against sexual violence in conflict, and reasserts the importance of implementing UNSCR 1325 and achieving effective coordination and promotion of gender mainstreaming within the $\mathrm{UN}$ system. ${ }^{26}$ Most recently, UNSCR 1889, passed 5 October 2009, highlights a range of broader concerns about women in post-conflict zones, stressing the need for female participation in talks and strategic development before, during and after conflict prevention and peacekeeping processes. Additionally, UNSCR 1889 supports the introduction of National Action Plans to implement UNSCR 1325.27 UNSCR 1820,

${ }^{22}$ A. Barrow"[It's] like a rubber band.' Assessing UNSCR 1325 as a gender mainstreaming process' Intemutional Joumul of Law in Context, Vol. 5, No. 1, (2009) p. 67; L. J. Shepherd Gender, Violenae and Security: Discourse as Practice (Zed Books, London, 2008).

${ }^{23}$ N. Al-Ali and N. Pratt What Kind of Liberation? Women and the Occupation of Iruq (University of California Press, Berkley, 2010).

${ }^{24}$ See also H. F. Carey 'Women and Peace and Security': the Politics of Implementing Gender Sensitivity Norms in Peacekeeping' Intermational Peacekeeping Vol. 8, No. 2 (2007), pp. 49-68.

${ }^{25}$ United Nations Security Council Resolution 1820 (UNSCR 1325) 18 June 2008: S/RES/1820 (2008).

20 United Nations Security Council Resolution 1888 (UNSCR 1888) 30 September 2009: S/RES/1888 (2009).

${ }_{27}$ United Nations Security Council Resolution 1889 (UNSCR 1889) 05 October 2009: S/RES/1889 (2009). At time of writing, only sixteen countries (Austria, Belgium, Chile, Cote D'Ivoire, Denmark, Finland, Iceland, Liberia, Norway, Portugal, Spain, Sweden, Switzerland, The Netherlands, Uganda and the United Kingdom) have passed National Action Plans (NAP). Serbia is in the early stages of discussions about the possibility of adapting a NAP, which is very briefly discussed in the conclusions of this thesis. See hitp://wwivuninstraw,org/con/aps/aps-homopuge/national-action-plins-on-resolution-1325-8.html [accessed 25 February 2010]. 
1888 and 1889 are rarely touched upon in this thesis, in part because it is not yet clear how feminist and women's organisations in Serbia are thinking about, affected by, or deploying these resolutions. However, the existence of these resolutions serve as a reminder that discourses about gender and security are beginning to make contact within the UN system in a noticeable way.

Although UNSCR 1325 was a document which aimed to alter the practice of UN peacekeeping processes, much work has pointed to how feminist organisations have often seized upon the opportunities offered by UNSCR $1325 .{ }^{28}$ This is hardly surprising, given that key actors within the transnational women's movement between 1998 - 2000 were critical forces for pushing the Security Council to pass a resolution considering gender. ${ }^{29}$ Many analyses of UNSCR 1325 highlight how feminist and women's organisations have taken up UNSCR 1325 with aplomb in various postconflict contexts. ${ }^{30}$ While this is true, it is noticeable that NGOs only use UNSCR 1325 in certain contexts and in certain ways. For example, many feminist-pacifists find UNSCR 1325 problematic as the discursive foundations of the resolution fail to present a significant challenge to questions about militarism and gender within institutions of war and peace. ${ }^{31}$ Hence, it is important to ask questions about which NGOs are explicitly using UNSCR 1325, why, and how they are using the resolution. Conversely, it is also important to examine the extent that UNSCR 1325 has affected the activism of any civil society group with a gender concern that is operating in a post-conflict context: how are organisations affected by UNSCR 1325 indirectly, and what are the political impacts of this? This thesis seeks to expose the various ways in which UNSCR 1325 - and more importantly, the gender security discourse surrounding the resolution - has affected feminist and women's organising.

Towards the end of this thesis, two case studies concentrating upon debates constructing the feminist-pacifist and domestic violence agendas in Serbia are deployed to illustrate how gender

2a C. Cohn 'Teminist Peacemaking:', pp. 8-9; C. Cohn et. al. 'Women, Peace and Security: Resolution 1325' Intemational Feminist Joumal of Politics, pp. 130 - 140; C. Cohn 'Mainstreaming Gender in UN Security Policy:' and E. Porter Peacebuilding; Women in Intemational Perspectite Routledge, London, 2007).

29 F. Hill, M. Aboitiz, S. Pochlem-Doumbouya 'Nongovemmental Organizations' Role in the Buildup and Implementation of Security Council Resolution 1325' in Signs: Jowmal of Women in Culture and Society, Vol. 28, No. 4 (2003), pp. 1255 - 1269. See also C. Cockburn From Where ae Stand: War, Women's Activism and Feminist Anabysis (Zed Books, London, 2007) pp. 138 - 143; Florea Hudson Gender, Human Security and the United Nations, pp. $11-15,37-40$.

30 Porter Peacebuilding pp. 11 - 41; Cohn 'Feminist Peacemaking', pp. 8 - 9; Cohn et. al. 'Women, Peace and Security: Resolution 1325' pp. 130 - 140; Cohn 'Mainstreaming Gender in UN Security Policy:', pp. 185 - 206; P. Mills 'Working to Promote 1325 in Israel: Opportunities and Challenges Facing Activist Women and Isha L'Isha' Paper presented to The Boston Consortium on Gender, Security and Human Rights on November 29 2006, retrieved from hup://wwwsenderindsccurityory/mueting.hitml [accessed 10 February 2008]; C. Cohn et al Workshop on Strategies for Grassroots Implementation of Resolution 1325' Paper presented to The Boston Consortium on Gender,

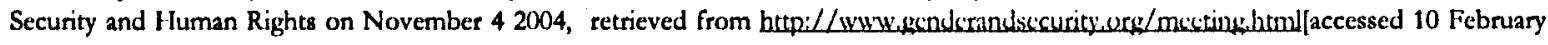
$2008]$.

${ }^{31}$ L. Mcleod 'Experience, Reflections and Learning: Feminist Organisations, Security Discourse and UNSCR 1325' in E. Svedberg and A. Kronsell (eds.) Making Gender, Making War. Violence, Military and Peacekecping Practices (Routledge, forthcoming). 
security discourse (including UNSCR 1325) has affected how NGOs have articulated and represented concerns relating to feminist-pacifism and domestic violence. These case studies, which explore contrasting logics of gender security discourse, indicate that security discourse and UNSCR 1325 have had an impact upon elements of feminist and women's organising: but not always in the ways expected or intended. However, the role of UNSCR 1325 in this thesis should not be overstated. While UNSCR 1325 is taken to be the discursive heart and nucleus of international gender security discourse, this thesis is not about UNSCR 1325 per se. Rather, it is about gender security discourse: and currently UNSCR 1325 is the strongest and most powerful articulation of this discourse. This thought echoes a point made by Helen Kinsella: that the possibilities presented by UNSCR 1325 'extend far beyond the structural limitations and capacities of the United Nations and the 1325 'network' of advocates - the potential of 1325 in this regard [as a productive force], is really enormous'. ${ }^{32}$ The thesis highlights that one of the potential effects of UNSCR 1325 exists in the possibilities for a (re)conceptualisation of what is meant by "gender security", especially within civil society.

\section{Destabilising "Post-conflict"}

UNSCR 1325 is viewed as a UN document operating primarily in post-conflict zones, and as such, perceptions and attitudes of activists about Serbia's complex relationship to "post-conflict" are important. Like security discourse, "post-conflict" is a discourse that has a particular temporal and spatial aspect. A "post-conflict zone" is thought of as an area that has been impacted by, and affected by, war and violent conflict within its boundaries. Feminists recognise that security problems do not cease with the official end of war: post-conflict areas face continued and renéwed insecurities, as 'while the guns are silent or the machetes temporarily laid aside, cultural, domestic and structural violence remains. ${ }^{33}$ A single war can affect countries in a variety of (sometimes unexpected) ways in the postwar moment, even where the theatre of war was not within "their space". ${ }^{34}$ Problematisiting "post-conflict" is not to say that a war or conflict did not occur, but rather, that 'we have thought the specific configuration of the conflict into existence', 35 Conflict, and post-conflict, is a state of existence crafted in particular highly politicised ways, where certain

\footnotetext{
${ }^{32}$ Kinsella, cited in C. Cohn et. al. 'Women, Peace and Security: Resolution 1325', p. 136. Kinsella was talking about the productive force of UNSCR 1325 in how we think about gender, but her thoughts can be usefully extended.

${ }^{33}$ Porter, Peacebuilding, p. 29.

${ }^{34}$ C. Cockburn and D. Zarkov 'Introduction' Cockburn, C. and Zarkov, D. (cds.) Tho Postwar Moment: Mititaries, Mascutinitios and Internutional Peacekeeping Bosnia and the Netherlands (L.awrence and Wishart, London, 2002), p. 9.

${ }^{35} \mathrm{M}$. Zalewski 'Intervening in Northem Ireland: Critically re-thinking tepresentations of the conflict' Critical Review of Imeermational Saral and Political Philasophy, Vol. 9, No. 4, (2006), p. 481
} 
problems are thrown into focus and others are downplayed. ${ }^{36}$ Serbia provides an unusual example in this respect because the state is simultaneously imagined as a post-conflict zone and not as a postconflict zone. The contestability of the Serbian state's trajectory to war, conflict, and war-related violences make Serbia a suitable study for the effects of post-conflict gender security discourse. The following outline of Serbia's political context clarifies the complex and problematic connection that Serbia has with "conflict" and "post-conflict".

Serbia is a land-locked country located at the crossroads of central and south-eastern Europe, with a population of 7.35 million people. ${ }^{37}$ Bordering Serbia are eight countries: Hungary, Romania, Bulgaria, The Former Yugoslav Republic of Macedonia, Kosovo, ${ }^{38}$ Croatia, Bosnia-Herzegovina, and Montenegro. The capital, Belgrade, is one of the largest cities in Southeastern Europe. Other major cities in Serbia include Novi Sad to the north, Niš to the south-east, and Novi Pazar to the southwest. From 1943 until 1992, what we now know as Serbia was the Socialist Republic of Serbia, one of six constituent republics within the Socialist Federal Republic of Yugoslavia. Led by Josip Broz Tito, Yugoslavia was a communist state which broke away from the Comiform and the Soviet Union during 1948.39 Yugoslav communism was relatively decentralised, depending upon a system of selfmanagement and decision-making operated through Workers' Councils, a modified form of direct democracy. ${ }^{40}$ The state's foreign policy depended upon non-alignment, enabling Tito's Yugoslavia to negotiate a path allowing warm relations with both the Capitalist West and the Soviet bloc.41 Pressures for further decentralization during the 1960s resulted in a new constitution in 1974 devolving all state functions, bar defence and overall monetary and fiscal control, to the six republics. ${ }^{42}$ The 1974 constitution granted more autonomy to the Serbian provinces of Vojvodina (to

\footnotetext{
${ }^{30} \mathrm{~N}$. Vaughan-Williams "Towards a Problematisation of the Problematisations that Reduce Northern Ireland to a "Problcm" Critical Review of Intermutional Social and Political Philosapty, Vol. 9, No. 4, (2006), pp. 513-26.

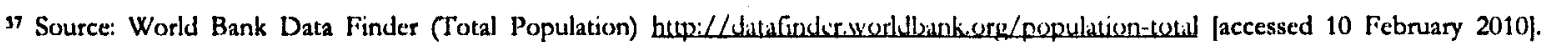
These figures are based upon statistics collected in 2008, and does not include the large number of refugees (typically from Croatia or Bosnia-1 lerzegovina) currently residing in Scrbia: 86,000 registered refugees as of January 2010

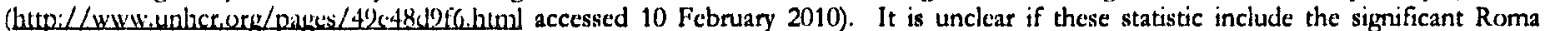
minority in Serbia, which according to the 2002 population census there are 108,000 Roma in Serbia, but World Bank estimates put the

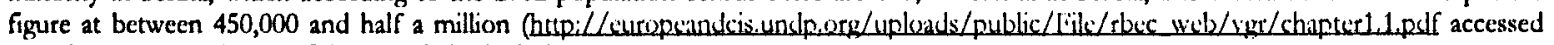
10 February 2010). None of these statistics include Kosovo.

36 The border with Kosovo is disputed. Kosovo declared independence on 17 February 2008, a declaration not recognised by the Government of Serbia.

39 M. Glenny The Balkans 1804 .1999: Nationalism, War and The Great Pouvers (Granta Books, Londion, 2000), pp. 529 - 536 and N. Davis Europe: A History (Pimlico, London, 1997), p. 1100.

40 F. W. Neal 'Yugoslav Communist Theory' American Slavic and East European Review, Vol. 19, No. 1 (1960), pp. 42 - 62 and M. Glenny The Balkanr 1804 -1999;, p. 575.

41 Glenny The Balkans 1804 -1999, p. 570.

42 J. Feffer Shocksuates: Eastem Europe Ajler The Revolutions (Black Rose Books, Montréal, 1992), p. 259.
} 
the north) and Kosovo (to the south). ${ }^{43}$ During the 1970s, economic disparity across Yugoslavia grew: parts of Croatia, Slovenia and northern Serbia became prosperous while Kosovo faced a state of economic decline: by 1980, Kosovo had the highest unemployment rate in Yugoslavia. ${ }^{44}$ After Tito's death in 1980, tensions in Kosovo reemerged. Protests and riots demanding republic status amongst Kosovar Albanians during the spring and summer of 1981 sparked off discontent and suspicions between ethnic Serbs and ethnic Albanians which continued to rumble throughout the 1980s. ${ }^{45}$

From the mid-1980s, Slobodan Milošević exploited tensions in Kosovo to establish his political career, eventually becoming the leader of the Yugoslav federation. ${ }^{46}$ Drawing upon nationalist, proSerbia rhetoric, Milošević cast himself as a 'defender of the Serbs', revoking the autonomy of Vojvodina and Kosovo by 1989.47 Apprehensive about Miloševićs pro-Serbia policies, individual republics pulled away from the Yugoslav federation following the first free elections in April 1990.48 Slovenia achieved independence following a brief war with the Yugoslavian federal army during the summer of 1991.49 Croatia, under the leadership of Franjo Tudjman, sought independence at the same time, but conflict was drawn-out and violent: in part because of the high population of ethnic Serbs in parts of Croatia. Croatian independence was formally recognised by the EU in January 1992.50 A tragic and complex three-way civil war broke out in Bosnia-Herzegovina in April 1992, formally ended through the Dayton Peace Accords in 1995.51 The wars in Croatia, and especially Bosnia-Herzegovina, attracted much international coverage, interest and horror as stories of systematic rape, genocide and ethnic hatred emerged. ${ }^{52}$ The Srebrenica massacre where some 7000

${ }^{43}$ Glenny The Balkans $1804-1999$, p. 593.

44 A. Babuna 'The Albanians of Kosovo and Macedonia: Ethnic Identity Superseding Religion' Nationalities Pupers, Vol. 28, No. 1 (2000), p. 71. These economic disparities remain apparent today: coastal Croatia, Slovenia and northem Serbia remain relatively wealthy compared to Southern Serbia, Macedonia and Kosovo.

45 Ibid., p. 72.

46 Ibid, pp. 72 - 3. See also L. Freedman 'Victims and Victors: Reflections on the Kosovo War' Retiew of Intemational Stwdies, Vol. 26 (2000), pp. $345-348$.

47 Ibid, p. 73, Glenny The Balleans $1804-1999$, p. 627.

4a V. Meier Yugaslavia: A History of its Demise (Routledge, London, 1999), p. xii

49 A. Agh The Politics of Central Europe (Sage, London, 1998), p. 174.

so Meier Yugaslantu: A History of itr Demise, p. xiv

3t Agh The Politics of Cenirul Europe, p. 179.

52 There is a vast literature on the atrocities in Croatia, and especially Bosnia-Herzegovina, during the early 1990s. On systematic warrelated rape (also framed as genocidal rape) see B. Allen Rape Warfare: The Hidden Genocide in Bornia-Herzegorina and Cnxutia (University of Minnesota Press, Minneapolis, 1996), A. Stiglmayer (ed.) Mass Rape: The War against Women in Bosnia-Herzegatina (University of Nebraska Press, Lincoln, 1994) and P. Stanley 'Reporting of Mass Rape in the Balkans: Plus ca chunge, plus c'est la meme chose? From Bosnia to Kosovo' in Civil Wars Vol. 2, No. 2 (Summer 1999), pp. $74-110$. 
Bosnian Muslim men and boys were executed, or went missing, presumed dead after the enclave, in northern Bosnia, fell to Bosnian Serb forces in July 1995 is considered one of the worst atrocities of the war in Bosnia-Herzegovina. ${ }^{53}$ Of critical importance to the politics of some activists investigated in this thesis is the role that the nationalist politics of the Serbian state under the leadership of Milošević is thought to have played in the conflicts in Croatia and Bosnia-Herzegovina. As will be made clear in chapter three, perspectives about the role of the Serbian state in these conflicts affect the gender politics of activists.

In Serbia, the 1990 s were characterised by heavy political repression under the dictatorship of Slobodan Milošević. Coverage of the wars in Croatia and Bosnia-Herzegovina were 'narrated in abstracted ways which resembled epic poetry and drew on national mythology'.54 In addition, 'along with watching the over-mediated war on television, most [in Serbia] also experienced it second-hand through friends who became refugees, soldiers and then veterans and invalids'.55 Against this violently nationalist background, a combination of international economic sanctions and Milošević's economic policies which devoted much government expenditure to the Yugoslav war machinery had a devastating impact upon many individuals in Serbia, who faced a crippling economic situation. Hyperinflation was rampant during the early 1990s, climaxing in January 1994, when the official monthly inflation rate was 313 million per cent. ${ }^{56}$ Throughout the 1990 s, Kosovo remained a site of intense nationalism, resulting in human wrongs attributed to Milošević's pro-Serb policies. In response to atrocities in Kosovo, NATO countries took the step of bombing much of the transport and industrial infrastructure and many urban areas in Serbia and Kosovo between March and May 1999, a step that continues to cause resentment in Serbia today. These events place Serbia in a problematic and complex location in relation to the wars in the region during the 1990s: theoretically, the Serbian state did not go to war with another state, but the Serbian state is thought to be a key collaborator in the conflicts, (re)produced violent nationalist and war-like rhetoric, and Serbia suffered many of the social, cultural, political and economic impacts and effects of war, in addition to facing aerial bombardment at the hands of NATO.

33. Obradović-Wochnik 'Knowledge, Acknowledgement and Denial in Serbia's Responses to the Srebrenica Massacre' Joumal of Contemporay Eumpean Sicudies, Vol. 17, No. 1 (2009), p. 61.

s4 Quotation retrieved from Obradović-Wochnik 'Knowledge, Acknowledgement and Denial', p. 62. See also D. Žarkov The Body OfWar: Media, Ethnicity, and Gender in the Break-kp of Yugarlavia (Duke University Press, Durham and London, 2007). Of course, Croatia, BosniaHerzegovina and Kosovo also drew upon nationalist narratives.

3s Obradović-Wochnik 'Knowledge, Acknowledgement and Denial', p. 71.

so S. H. Hanke 'The World's Greatest Unreported Hyperinflation' initially published in Globe Assa, May 2007. Retrieved from CATO Institute http://www.catco,org/pub display,php? ${ }^{2}$ ub id =8232 [accessed 9 March 2010]. 
The "wartime" story is replete with complexities and confusions: many of these tensions spill over into the apparently "post-conflict" era. The democratic changes in Serbia since the fall of Milošević in October 2000 has been troubled and marked with difficulties. Drastic and uneven political changes have been compressed in a very short time period. Elections have been volatile, resulting in marked swings between a pro-European Union integration, "progressive" left and a nationalisticallyorientated right whose aim is the protection of the "territorial integrity" of Serbia. ${ }^{57}$ In 2003, the first democratically elected Prime Minister, Zoran Djindjic, was assassinated as result of a plot originating from circles of organised crime and former security forces. A point of contention between Serbia and the European Union has been the extent of Serbian cooperation with the International Criminal Tribunal for former Yugoslavia (ICTY). These political difficulties have been set against a background of extremely polarised rhetoric dividing nationalist and European Union oriented political forces in Serbia. After Kosovo declared independence in February 2008, there were localised nationalist rallies and riots culminating in the destruction of perceived symbols of American imperialism in Belgrade: the US embassy, Nike shops and McDonald restaurants. With the election of the centre-left Democratic Party representative, Boris Tadić, as President of Serbia in January 2008, and a loosely centre-left coalition Government following Parliamentary elections in May 2008, it is thought that Serbia is beginning to pursue a policy looking to European integration. The government has taken a number of actions interpreted as an attempt to break away from the war policies of the 1990s. The arrest of the fugitive Randovan Karadžić, accused of orchestrating the siege of Sarajevo and the genocide at Srebrenica, in July 2008 was "widely heralded as signalling a change in Serbian politics and cooperation with the ICTY'.58 In December 2009, Serbia formally declared its application for the European Union. A parliamentary resolution condemning the crimes in Srebrenica was adapted during March 2010.59 However, debates in the months before, the parliamentary resolution was passed highlighted social and political tensions that exist in relation to Serbia's role in the wars of the 1990s.60

Postconflict political tension in Serbia centres upon the notion of political responsibility for the war crimes committed by the Serbian state during the 1990s. The aim of the political responsibility project is to 'raise public awareness on the issue of war crimes, and to foster the discussions on crimes and responsibility', and to 'raise the questions of collective responsibility, collective guilt, and

\footnotetext{
37 Between October 2000 and February 2010, Parliamentary elections were hold in Serbia in 2003, 2007 and 2008. Presidential elections took place in September 2002, December 2002, 2003, 2004 and 2008. Municipal and city elections took place in 2004, 2008 and 2009. A refercndum was held on the Serbian Constitution in 2006. "Territorial integrity" in essence means retaining Kosovo as part of Serbia.

58 Obradović-Wochnik 'Knowledge, Acknowledgement and Denial', p. 62.

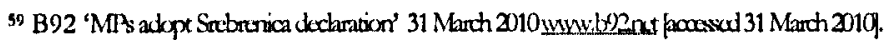

${ }^{60}$ B92 'Opinion poll on Srebrenica resolution' 3 February 2010 www.b22. nct [accessed 05 March 2010]. The survey was conducted by a newspaper in Novi Sad, Dnemik. It found that $20.6 \%$ of citizens would support the resolution, while $46.2 \%$ would support a resolution that also condemned genocidal acts committed by Croats and Albanians towards Serbs.
} 
the need for collective apologies' for war crimes committed during the 1990s.61 Since very few institutions, publications or individuals in the country, however, are ready to openly accept the ICTY's version of the war crimes which occurred, particularly the Srebrenica massacre', any public declaration of support for the political responsibility agenda tends to be perceived as anti-Serbian. ${ }^{62}$ A 2005 survey showed that $81 \%$ of Serbs believed that Serbs were the greatest victim of the wars in the 1990s, and while the majority of the population believe it important to face the truth about the events of the 1990 s, $47 \%$ think that this truth is important because it will prove that Serbs were not responsible for the war crimes ascribed to them. ${ }^{63}$ Furthermore, around $50 \%$ of the Serbian population deny or question the circumstances surrounding Srebrencia. ${ }^{44}$ Opinions differ over the relative importance of political responsibility to Serbia's post-war progress: for some, the notion that Serbia bears any sort of responsibility for the war crimes of the 1990s (e.g. Srebrenica) are lies perpetuated through an anti-Serbian western-centric foreign policy, while others insist that social and political progress cannot be made unless political responsibility is accepted, while others are in the process of accepting their knowledge and attempting to comprehend it within culturally acceptable boundaries. ${ }^{65}$

The intricacy of the Serbian state's relationship to war during the 1990 s has spilled over into the apparent "post-war" era. On the one hand, Serbian society remains affected by, and shaped by, the nationalist war policies of the 1990 s, but on the other, there was no prolonged conflict within the territorial boundaries of Serbia, and there is a sense that Serbia did not go to war as in Croatia and Bosnia-Herzegovina. Many activists express uncertainty about the relationship between Serbian territory and war. ${ }^{66}$ It is useful here to turn to Christine Sylvester's insistence that we consider ways

61 O. Fridman 'Altemative Voices in Public Urban Spaces: Serbia's Women in Black' Eithnologia Balkanica, Vol. 10 (2006), p. 296.

62 Obradovic-Wochnik 'Knowledge, Acknowledgement and Denial', p. 63.

63 D. Duhaček 'The Making of Political Responsibility: Hannah Arendt and/in the case of Serbia' J. Lukić, J. Regulska and D. Zaviršck Women and Citizenship in Centrul and Eiastem Europe (Ashgate, Hampshire, 2006), p. 205. The poll was conducted by the SMMRI (Strategic Marketing and Media Research Institute), now known as IPSOS Strategic Marketing. A similar survey was repeated in 2009, showing that the majority of Serbs believe that the IC'TY is biased against Serbs: sce the surveys at help://coplish.bigcontar.ory.rs/ [accessed 3 June 2010]. A similar survey, carried out by a different polling company suggests that the picture does not look very different in 2010 : polling by the National Council for Cooperation with the Hague Tribunal, indicates that 'as many as 55.2 percent of those polled believe that the crime committed in Srebrenica was "maliciously blown out of proportions by our enemies and media": see "Opinion poll on Srebrenica Resolution' htpi//wawib22ant/ang/ncws/ [accessed 3 June 2010].

o4 Statistic from Belgrade Human Rights Centre and Strategic Marketing, 2005, cited in Obradović-Wochnik 'Knowledge, Acknowledgement and Denial', p. 62. It should be noted that accurate figures are difficult to obtain, and that such surveys oversimplify the dynamics of denial, but thcy are useful in demonstrating that a significant proportion of the Serbian population do not acknowledge that war crimes were committed by the Serbian state.

6s The first two points are my own observations from my time in Serbia and from reading Serbian media outlets. The third point is from Obradovic-Wochnik 'Knowledge, Acknowledgement and Denial'.

so While conducting interviews, I heard a wide range of positions, including unequivocal denials that Serbia ever went to war, stances which suggested that the NATO bombing of Serbia was 'like a war', perspectives that while Serbia suffered during the 1990s, this suffering was not as great as those in Croatia and Bosnia-Herzegovina, and views that Serbia was a key collaborator in the conflicts. See V. Litrichin and 
in which we "touch war": war affects many 'differently located people... in physical, intellectual, and emotional ways'.67 Sylvester suggests that the impact of war is not easy to pin-point: the post-war and post-conflict space is no different. Many analyses of post-war reconstruction and peacekeeping highlight the gender impacts of post-war spaces. ${ }^{68}$ This is critical as how "post-conflict" is thought about affects the performance of gender, and how international organisations distribute their funding and shape their projects. The notion that "post-conflict" is a complex and unstable phenomenon remains important to analysis, and Serbia is recognised to have different locations and positions in relation to the wars of the 1990s. This thesis will highlight ways in which a "post-conflict" zone is constituted and mediated, and how gender politics and security discourse are shaped by personalpolitical imaginations of conflict and post-conflict.

\section{Profiling Gender Politics}

Analysis in this thesis highlights that particular gender politics adopted by activists of feminist and women's organisations in Serbia affects the specific configuration of security discourse. The term "gender politics" is used in this study to describe the political profile held by an individual or organisation about gender or feminism. As will become clear in chapter three, which overviews feminist and women's organising in Serbia, these political perspectives about gender and/or feminism intersect with the position taken in relation to "post-conflict". However, "gender politics" are not just a set of ideas about feminism: the notion also refers to how activists relate and practice these ideas within their immediate social and political environment, highlighting the extent to which private views about feminism are expressed in public. Inspired by Cynthia Enloe's insistence that the personal is political, and that the political is also personal, my analysis emphasises connections between personal and political configurations of gender politics, illuminating how these gender politics shape security discourse. ${ }^{69}$ That is, personal attitudes about gender and/or feminism shape the political objectives of activists, including their position on "gender security" (and vice versa).

L. Mladjenović 'Belgrade Feminists: Scparation, Guilt, and Identity Crisis' in T. Renne (ed.) Ana's Land: Sisterhood in Eastem Eumpe (Westview Press, Oxford, 1997), pp. $179-185$ for some further perspectives.

67 This was the theme of a six month-long programme of workshops, lectures and cultural events at Lancaster University, UK during 2008 - 09, organised by Christine Sylvester. See C. Sylvester (ed.) Experiencing War (Routledgc, London, 2011). Quotation retrieved from http://wwi.lancs.aculk/fass/events/touchingwar/ [accessed 09 March 2010]

68 See Cockburn and Zarkov The Postwar Moment, L. Handrahan 'Conflict, Gender, Ethnicity and Post-Conflict Reconstruction' Securify Dialogue Vol. 35, No. 4 (2004), pp. 429 - 445; M. Korać 'Gender, Conflict, and Peace-building. Lessons from the Conflict in the Former Yugoslavia' Wamen's Studies Intemational Forum, Vol. 29 (2006), pp. 510 - 520; C. Corrin 'Post-Conflict Reconstruction and Gender Analysis in Kosova' International Feminist Joxmal of Politics, Vol. 3, No. 1 (2001), pp. 78 - 98; V. Nikolić-Ristanović 'War and Post-War Victimization of Women' Eumpean Joumal of Crime, Criminal Law and Criminal Justic, Vol. 10, No. 2 - 3 (2002), pp. 138 - 145 and P. Higate and M. Henry Insecure Spaces: Peacekeeping, Power and Performance in Haiti, Kosowo and Liberia (Zed Books, London, 2009).

${ }^{69}$ C. Enloe Bananas, Beaches and Bases: Making Feminist Sense of International Politics (University of California Press, Berkeley, 2000), pp. 195 197. 
In Serbia, the profile of gender politics is profoundly affected by the activist's personal-political imaginations of the past conflict and hopes for the future of post-conflict reconstruction. These connections between perspectives about feminism and Serbia's post-conflict position, which make up the gender politics of activists and organisations, are made in part because of Serbia's problematic association with "conflict" and "post-conflict". These issues are explored in-depth in chapter three, but generally, there is a perception that to be "feminist" is to be anti-war (and consequently, antiSerbian). As a consequence, many activists are reluctant to be associated with feminism - either for strategic or personal beliefs. These attitudes, described as the gender politics held by individuals and organisations, shape the way that activists signify, articulate and represent security discourse within their policy agendas. That is, how "conflict" and "post-conflict" in Serbia is thought about and experienced relates to the hopes for the direction of future post-war reconstruction, and therefore affects the profile of gender politics adapted. The extent to which, and ways that, critiques about war and nationalism, or concerns about political responsibility are foregrounded in the performance of gender security discourses is heavily dependant upon the gender politics held by the activist concerned.

Defining what constitutes a feminist organisation, a women's organisation, or a gender interest is a tricky process, blurred by the presence of various organisational networks and connections, as well as the occasional chasm between the personal beliefs of the individual activist and the aims and objectives of an organisation. References to feminist organisations, women's organisations and gender interests are deliberate throughout this thesis, and so it is necessary to briefly outline the differences.

I. Feminism and Feminist Organisations. Defining "feminism" is controversial, but a minimal definition would require a belief that gender relations are unbalanced and something should be done about it. There is no agreement (and nor is agreement necessary) about why or how gender relations are unequal or what should be done about this apparent inequality. It will become apparent that the explicitly feminist organisations and activists in Serbia often have close associations with ideas about political responsibility. As a consequence, many feminist activists and organisations face an occasionally antagonistic socio-political environment which is hostile towards the concept of feminism and the critiques of the political context made by some feminists.

II. Women's Organisations. As pointed out by many feminist scholars examining (gendered) social movements; feminist activists, organisations or movements are not synonymous with women's 
activism, organisation or movements. ${ }^{70}$ Women's organisations mobilise women around a set of interests relating to issues faced by women (for example; domestic violence), and while some activists within these groups may hold feminist beliefs or goals, not all activists will have the transformative aims held by feminists.

III. Gender Interests. This term can be used to incorporate both feminist and women's organisations, but is also used in this thesis to refer to certain civil society organisations which do not focus upon explicitly gendered issues, but where many activists have close connections with feminist and women's organisations, or where they conduct activities placing gender inequality or interests at the heart of the practical analysis or issue to be dealt with.

This thesis is unique in its concern with understanding the effects perceptions about conflict and post-conflict reconstruction have upon the gender politics of activists in Serbia. Much of the literature concerned with feminist and women's organising has concentrated on the effects of postcommunist contexts or democratic transition, and many of the themes that they throw up are beyond the scope of this thesis. For instance, a body of literature analyses feminist and women's organising in other parts of Eastern Europe and Russia. ${ }^{71}$ It is important to stress that Yugoslavia experienced communism differently to the USSR and the Soviet bloc. However, much of Eastern Europe shares similar characteristics to Serbia in relation to some of the negative social attitudes towards feminism and with gender inequalities rendered apparent in the post-communist era. ${ }^{72}$ Another debate that has dominated the area has been the social movement literature concerned with Russia, which has discussed the role of international donors in shaping civil society concerns. ${ }^{73}$ Post-communist transitions, social attitudes towards feminism and the presence of international donors all impact

\footnotetext{
${ }_{70}$ For example; K. Beckwith 'Bcyond Compare? Women's Movements in Comparative Perspective' in Eumpean Joumal of Political Reseant Vol. 37, No. 4 (2000), pp. 431 - 469, S. E. Alvarez Engendering Demacracy in Brazil: Women's Motements in Transition Politics (Princeton University Ptess, Princeton, 1990), pp. 24 - 27, G. Waylen Engendering Transitions: Women's Mobilization, Institutions, and Gender Outcomes (Oxford University Press, Oxford, 2007), pp. 52- 53, Molyneux, M., 'Mobilisation without Emancipation? Women's Interests, the State and Revolution in Nicaragua' Feminist Studies, Vol. 11 (1985), pp. 227 - 254, and 'Analysing Women's Movements' in Feminist Visions of Dexelopment: Gender Analysis and Poliy (eds.) C. Jackson and R. Pearson (Routledge, London, 1998), pp. 65 - 87. ,

${ }^{71}$ Key staraing points include B. Einhom Citizenship in an Enlarging Eumope: From Dream to Awrkening (Palgrave, Basingstoke, 2006); J. Lukić, J. Regulska and D. Zaviršek (eds.) Women and Citizenship in Central and Eastem Eumpe (Ashgate, Aldershot, 2006).
}

72 T. Renne (ed.) Ana's Land: Sisterhood in Eastern Eumpe (Westview Press, Boulder, Colarando, 1997); B. Einhom and C. Sever 'Gender and Civil Society in Central and Eastem Europe' Intemational Feminist Joumal of Politics, Vol. 5, No. 2 (2003), pp. 163 - 190; A. Cerwonka 'Travelling Feminist Thought: Difference and Transculturation in Central and Eastern European Feminism' Signs: Joumal of Women in Cullure and Saciety, Vol. 35, No. 4 (2008), pp. 809 - 832; D. Roman 'Gendering Eastem Europe: Pre-feminism, Prejudice, and East-West Dialogues in Post-Communist Romania' Women's Studier International Fiorum, Vol. 24, No. 1, pp. $53-66 ;$ N. Funk and M. Muells (eds.) Gender Politicr and Past-Communism: Refectionr from Eastem Eumpe and the Former Sotief Union (Routledge, London, 1993); L. Occhipinti Two Steps back? Anti Feminism in Eastern Europe' Amthropology Today Vol. 12, No. 6 (1996), pp. 13 - 18; J. Acsädy 'Urges and Obstacles: Chances for Feminism in Eastern Europe' Women's Sicudies Intermational Forum, Vol. 22, No. 4, (1999) pp. $405-409$.

${ }^{73}$ V. Sperling Organising Women in Cantemporary Rusiag: Engendering Transition (Cambridge University Press, Cambridge, 1999); S. L. Henderson Building Democray in Contemporary Russia: Western Support for Grassnots Onganisations (Comell University Press, Ithaca, 2003); L. McIntosh Sundstrom Funding Cinil Society: Foreign Assisfance and NGO Development in Russia (Stanford University Press, Stanford, California, 2006); J. Hemment Empowering Women in Russia: Actirism, Aid, and NGOs (Indiana University Press, Bloomington and Indianapolis, 2007); J. E. Johnson Gender Violence in Ruisia: The Politics of Feminis/ Internention (Indiana University Press, Bloomington and Indianapolis, 2009). 
upon gender politics in Serbia: but the Serbian context has also been deeply affected by "postconflict" issues. As a consequence, while recognising that the effects of communism and international donors are important factors in the shaping of gender politics, my concerns about the effects of gender politics are firmly located within a post-conflict context.

Much of the literature concerned with gender and the wars in ex-Yugoslavia highlights nationalism as a key factor shaping gender relations before, during and after the conflicts. Feminist commentators have highlighted how the processes of nationalism are highly gendered, crafting an image of women as 'biological reproducers of the nation'.74 The literature looking at how the workings of nationalism in Serbia (and other parts of ex-Yugoslavia) have had a range of gendered impacts is extensive: highlighting the impacts of nationalism upon migration, marriage, motherhood, masculinities...75 While nationalism is evidently an important process that profoundly affects the workings of "gender" in Serbia, the focus of this thesis is not on the processes or workings of nationalism. Rather, nationalism is only examined insofar as it is a process that might have shaped personal-political imaginations of conflict and post-conflict.

A major theme for scholars concerned with feminist and women's organising has been the effects of democratic transition upon how organisations relate to the state. This is particularly the case with the literature relating to women's organising across Latin America. ${ }^{76}$ Serbia is a country undergoing a convoluted and difficult transition to democracy, and is in a period of intense institution-building, and as such, it is impossible and undesirable to ignore these contexts as factors affecting the gender politics of activists and organisations. However, in attempting to understand activist configuration of gender security, I believe it more useful to focus on the post-conflict context, (semi-)isolating debates about the effects of post-conflict from concerns about democratic transitions and institutionbuilding. In part, this is because UNSCR 1325, which is taken as the discursive nucleus of security discourse examined, is viewed as a resolution that operates in post-conflict contexts. As a consequence, the two case studies on feminist-pacifism and small arms and light weapons (SALW)

\footnotetext{
74 Quotation from N. Yuval-Davis 'Women and the Biological Reproduction of "The Nation"' Women's Studies International Formm, Vol. 19, No. 1-2 (1996), pp. 17 - 24. Sce also T. Mayer (ed.) Gender Inonies of Nationalism: Sexing the Nation (Routledge, London, 2000).

${ }^{3}$ For instance: Milić, A. Nationalism and Sexism: Eastern Europe in Transition' in R. Caplan and J. Fetter (cd.) Eumpe's Ney Nationalism: State and Minorities in Conflict (Oxford University Press, Oxford, 1996), pp. 169 - 183, C. S. Lilly and J. A. Irvine 'Ncgotiating Interests: Women and Nationalism in Serbia and Croatia, 1990 - 1997' East Exropean Politics and Sazieties, Vol. 16, No. 1, pp. $109-144$, J. P. Kaufman and K. P. Williams 'Who Belongs? Women, Marriage and Citizenship: Gendered Nationalism and the Balkan Wars' Intemational Feminist Journal of Politics, Vol. 6, No. 3 (2004), pp. 416 - 435, W. Bracewell 'Rape in Kosovo: Masculinity and Serbian Nationalism' Nations and Nationalisms, Vol. 6, No. 4 (2000), pp. $563-90$ and 'Women, Motherhood, and Contemporary Serbian Nationalism' Women's Siudies Internutional Forum, Vol. 19, No. 1 - 2 (1996), pp. $25-33$.

${ }^{76}$ Examples include S. Alverez Engendering Democray in Brazil and A. Lind Gendered Paradaxes: Women's Movements, State Restructuring, and Global Development in Ecuador (Pennsylvania State University Press, Pennsylvania, 2005).
} 
concerns in domestic violence (investigated in part two of this study), are located within post-conflict reconstruction programmes and concerns. Finally, in Serbia, gender politics is more profoundly shaped by attitudes towards war and conflict, and perceptions about Serbia's relationship to "postconflict", rather than the effects of democratic transitions.

Literatures that examine civil society in post-conflict contexts have been valuable for insights about how the gender politics of organisations have been shaped by aspects of conflict and post-conflict.77 However, many analyses of feminist activism in war tend to heavily focus upon feminist-pacifist perspectives, accidently reproducing dominant narratives about feminist activism in relation to war: a reproduction of a mode of thought which says that women are "natural" peacemakers. ${ }^{78}$ Deploying post-structural analytical approaches highlights how gender politics are constructed, escaping the assumption that feminist activists in war are naturally pacifist. To understand how gender politics are formed, an analytical strategy concerned with (1) experiences and memories about/from the past conflict, (2) present perceptions and attitudes towards Serbia's post-conflict present, and (3) hopes for the future direction of post-conflict reconstruction in Serbia is deployed. These multiple temporalities integrate to craft a personal-political imagination about conflict and post-conflict. The assumption then becomes that different activists have different perspectives and attitudes towards war and conflict: a perspective which is both personal and political. Hence, even though feministpacifist perspectives form a noticeable part of this study, by questioning how these gender politics have been constructed, the connections between personal and political perspectives are exposed.

Through an examination of intersections between gender politics and notions about "post-conflict", this study seeks to examine the extent to which gender security discourse has affected women's and feminist organising in Serbia since 2000. A poststructural perspective has been adapted as the best strategy for unpacking these questions, as poststructuralism provides the 'theoretical means to conceptualize the character and transformation of social structures, and to clarify the relationship between social structures, political agency and power. ${ }^{79}$ The poststructural approach that is taken is inherently feminist and gendered, following a theoretical commitment to pursuing a feminist scholarship that renders apparent various myths and mythologies that constitute the status quo in

$\pi$ Cockburn From Where me Stand and The Space Between Us: Negotiating Gender and National Identities in Conflict (Zed Books, London, 1998); M. R. Waller and J. Rycenga (eds.) Frontline Feminisms: Women, War, and Resistance (Routledge, London, 2001); W. Giles, M. de Alwis, E. Klein and N. Silva (eds.) Feminists Under Fin: Exchanges Across War Zones (Between the Lines, Toronto, 2003).

79 C. Sylvester, 'Riding the Hyphens of Feminism, Peace, and Place in Four- (or More) Part Cacophony' Altematives, Vol. 18, (1993), p. 110 and J. B. Elshtain, Women and War (University of Chicago Press, Chicago, 1995).

${ }^{79}$ Glynos and Jowarth Logics of Critical Explanation in Social and Political Theory p. 5. 
IR..80 With this feminist-poststructural approach, this thesis seeks to demonstrate that gender security discourse can affect the pattern of feminist and women's activism in a range of (sometimes surprising) ways. Through emphasising the temporal aspect of gender politics, the impact of these perspectives in shaping the performance of security discourse is made apparent.

\section{OUTLINE OF STUDY AND CASE STUDY SELECTION}

The central research objective of this study is to make sense of the extent feminist and women's organisations in Serbia have configured "gender security" between 2000 and 2009. To explore how "gender security" has been configured by feminist and women's activists in Serbia, it is critical to look at the gender politics that is product and productive of security discourse. In Serbia, perceptions about conflict and post-conflict shape gender politics, reverberating in understandings of "gender security". To investigate these themes, a feminist-poststructural approach is adapted: an approach concerned with understanding the discursive formation of "gender security" amongst activists in Serbia. The emphasis is upon understanding how memories, perceptions and hopes relating to conflict and post-conflict have shaped the discursive formation of "gender security". These memories, perceptions and hopes are termed as personal-political imaginations of conflict and postconflict. Chapter one outlines the approaches used in making sense of activist personal-political imaginations of conflict and post-conflict, and how these personal-political imaginations shape practices of gender security. The chapter begins with an outline of the data collection process, highlighting how a text of personal-political imaginations are formed, before exposing the feministpoststructural strategies used to analyse this data. The conceptualisation of "discourse" is unpacked, highlighting that a discourse does not have a single temporality: rather, a discourse is made up of multiple significations, articulations, and representations about and from the past, present, and future. This chapter aims to provide a sense of the approaches used to understand how security discourse within feminist and women's organisations have been problematised and configured.

The feminist-poststructuralist approach adapted informs the review of the security studies literature in chapter two. Functioning primarily as an overview of the academic literature in the field of Security Studies, chapter two outlines a range of ontological perspectives about security. Through an understanding of security as a discourse the subtle differences between the referent subjects and construction of "security" in various constituent parts of academic security studies will become apparent. This review of the literature is shaped by the belief that security is a performative

${ }^{80}$ M. Zalewiski 'Do We Understand Each other Yet? Troubling Feminist Encounters With(in) Intemational Relations' The British Joumal of Politics and Intemational Relutions, Vol. 9, No. 2. (2007), pp. 302 - 312; C. Sylvester 'The Contributions of Feminist Theory' in Intemational Theory: Positivism and Beyond (eds.) S. Smith, K. Booth and M. Zalewiski (Cambridge University Press, Cambridge, 2002), pp. 254 - 278. 
discourse, made up of significations and resignifications clustering around "security". These significations related to "security" operate to shape a particular logic of security. I follow Laura Shepherd in understanding logics as 'the ways in which various concepts are organised within specific discourses'. 81 That is, the specific logic of "gender security" represented is reliant upon how concepts - including gender and/or security - are arranged, as well as the 'the assumptions that inform [these representations], and the policy prescriptions that issue from them'. ${ }^{82}$ The insight that security is a discourse reflecting a particular logic serves to highlight that "security" is a highly politicised concept, constructed in particular ways for specific political purposes, and with particular political effects.

The configuration of, and extent to which, "gender security" is utilised by feminist and women's NGOs in Serbia in part depends upon the gender politics of activists. These gender politics are explored in chapter three, which outlines feminist and women's organising in Serbia since the late 1970s. While this chapter provides the historical and contemporary context to the case studies used in this thesis, it is more important for laying out the positions taken by activists towards gender politics, and highlighting the importance of war in shaping these gender politics. Outlining the areas of divisions and unity within gender activism in Serbia highlights how war shaped definitions of gender and/or feminism in Serbia. In brief, those activists and groups who are clear and unequivocal in their stance that the Serbian state should accept political responsibility towards the war crimes during the 1990s are known as "political" groups. So-called "non-political" groups are made up of activists who downplay the connections between gender and war, or who insist that the political responsibility project is not critical to their work. Political responsibility, as outlined earlier, refers to a concern with accepting responsibility for the war crimes committed during the 1990s in the name of Serbia. Through tracing the genealogy of women's and feminist organising in Serbia, the effects of values and political beliefs upon strategic positioning and relationships can be explained: a key factor influencing how and why gender security is configured.

Having set out the context of feminist organising in Serbia during chapter three, chapter four makes explicit some of the ways in which gender politics is product and productive of security discourse within feminist activists in Serbia. Chapter four investigates the claimed signification of security by gender activists in Serbia, highlighting ways in which the signification of security discourse is profoundly affected through (and by) ontological logics about "gender" and "post-conflict". The way feminist and women's NGOs in Serbia signify security is affected by their interpretation and

8) L. J. Shepherd 'To save succeeding generations from the scourge of war': The US, UN, and the Violence of Security' Review of Intermational Siudies Vol. 34, No. 2 (2008), p. 294.

${ }^{82}$ Ibid. 
perspective about/from the past(s), present(s), and future(s). The driving vehicle for analysis will be a deconstruction of responses to the question put to each participant during the course of field research: "what does security mean to you?" Gendered understandings of "security" in Serbia concentrated around practices and processes of insecurities concerned with human rights, gender violence and "everyday" transitional life. These elements form the centre of how activists define "gender security". It also becomes clear that these understandings of security are shaped by discursive logics relating to "post-conflict". Chapter four outlines how gender politics in Serbia, profoundly affected by the political responsibility debate, shapes the specific configuration of gender security practiced by activists, highlighting that the logic framing specific configurations of "gender security"

Together, chapters one to four form part one of this thesis, establishing the contexts, theoretical framework, and analytical strategies required for the in-depth exploration of (elements of) Serbian feminist and women's activism. In addition, part one delineates "security discourse" and "gender politics" before demonstrating ways in which these discourses combine to form a specific logic of gender security. Part two utilises the contexts established in part one to examine the extent to which activist conceptualisations of gender security reverberate through two policy concerns connected to UNSCR 1325. UNSCR 1325 is taken as the site of discursive contact between gender and security, facilitating comparison. The first case study zooms in on the feminist-pacifist debate in Serbia, while the second case study looks at debates surrounding policy responses towards the use of small arms and light weapons (SALW) in domestic violence cases. The case studies were selected because both were policy concerns that (1) gender NGO activists in Serbia were involved with, (2) UNSCR 1325 is woven through both issues, and (3) perspectives about conflict and post-conflict echo through both matters. In both case studies, an examination of how security discourses have shaped the contours of each policy debate exposes the various political impacts, purposes and uses of security discourse. Deploying an analytical strategy concerned with the temporal notions embedded within security discourse highlights the contrast between the articulation and representation of gender security within both case studies. The variations between the articulation and representation of security discourse in each case study serves to highlight some of the ways in which gender politics shapes, and is shaped by, security discourse.

The first issue, brought into sharp relief during chapter five, is the feminist-pacifist agenda and debates about peace, which centre on one NGO: Women in Black. By initially tracing the discursive terrain of Women in Black's antinationalist pacifist stance since 1991, it will be clear that from 2005, "security" was explicitly articulated and represented politically for strategic reasons, namely to support their political responsibility agenda. Critically, there has been no shift in ideational values held by 
Women in Black. Chapter six focuses upon the intervention of SALW concerns into the domestic violence debate in Serbia. Security discourse plays a different role here: the performance of gender security concerns within the international sphere altered the structure of the gender agenda about domestic violence, (re)asserting the importance of legal changes designed to restrict SALW (ab)use in domestic violence. Underpinning both case studies is the discursive terrain of UNSCR 1325. UNSCR 1325 has been product and productive of an alteration in the explict discursive logics adapted by international - and local - actors in relation to (gender) security in a "post-conflict" context. The resolution affects the drama of security discourse differently in each case study. This is not just because UNSCR 1325 is utilized in various ways by different actors for alternative purposes, but also because the various relationships attached to the security discourse embedded within UNSCR 1325 enables the resolution to be product and productive of various agendas utilising "security".

Understanding the variations in how gender security can be signified, articulated and represented matters because of the growing effect and impact of UNSCR 1325. The conclusions will evaluate the two case studies, highlighting the competing modes of thought about "gender security" and the policy impacts of these constructions. However, querying why and how security discourse is performed differently sheds an enormous amount of light upon the impact that gender politics and notions of "post-conflict" has upon the construction of (in)security. Who articulates security, where security is articulated, and why security is articulated can be revealing in unpicking the relative importance of ideas and concepts in international politics, explaining why some ideas come to the forefront while other ideas are excluded. The thesis aims to deliberately highlight the importance of various temporal notions about conflict and post-conflict in the signification, articulation and representation of gender security. In essence, security is a discourse located within a personalpolitical imagination that is shaped by multiple temporal perspectives. This approach exposes ways in which gender politics and notions about "post-conflict" affect how UNSCR 1325 and broader (gender) security discourse are (not) used by NGOs.

\section{ONTOLOGICAL MOMENTS}

Annick Wibben believes it to be important to 'tackle the politics of security - and underlying ontological and epistemological assumptions - head on'. ${ }^{83}$ This is the guiding premise of this thesis: security has a politics, and as such, a set of ontological and epistemological logics underpinning these politics. Ontology refers to the theory of being and existence, a reference to the contours that we

${ }^{83}$ A. T. R. Wibben 'Tuman Security: Toward an Opening' in Security Dialogue Vol. 39, No. 4 (2008), pp. 460. 
(think that we) see in the nature of things. A concern with the ontological status of ideas - such as gender security - matters because ideas, and ideational connections... are part of everything, and everything is real': denial of any reality 'extrudes or detotalizes' ideas, persons, consciousness, agency, values, mind or body from the world. ${ }^{84}$ By unpicking the ontological and epistemological groundings that significations, articulations and representations of gender security are delineated through, an appreciation of how international discourses affect the discourses of local actors becomes possible. Since a discourse is not merely a word, or a string of words with no external meaning, but rather a text moulding, constituting, reshaping and limiting processes and practices within the social world, a comprehension of some of the ways in which gender security is constituted matters. In other words, the way in which gender security is constituted is product and productive of a set of power relations outlining some of the processes and practices of international politics. Exposing the ways in which "security" is discursively constituted by women's and feminist NGO activists in Serbia reveals something about how "security" has a politics to both individuals and collectives across a broader tempo-spatial dimension. As such, it is critical to unpack (some of) the ontological assumptions about (gender) security held by particular NGO activists in Serbia - head on.

However, it is not just the ontology of the actors investigated in this thesis that outlines this investigation. The methodology and analytical framework adapted cannot be separated from the ontology or epistemology (the theory of knowledge) adapted by the researcher. Like many pieces of research, this project developed over time through a combination of flashbulb moments and slowly soldering together material and understandings. While it is not the only narrative that can be presented about my research process, there are a series of ontological moments that I would like to connect together and illuminate at this point. Initially, the research project set out to make sense of the connections between memories of war and nationalism during the $1990 \mathrm{~s}$, and contemporary feminist policy objectives regarding "security" in Serbia. Upon beginning field research I quickly realised that these memories were mediated by other temporal considerations: in particular, future hopes and contemporary (political, social and economic) perceptions. If the activist talked about "the past" - and sometimes, they would not - the selection of "the past", the recalled memory, and (significantly), the ontological logics underpinning the memory embodied a certain politics which defines and constitutes the very practice of "remembering". Reading and re-reading the interview transcripts, it became impossible to separate memory from other instances and presences of time, especially given that activists were talking about their contemporary "realities" and objectives. And so, the research questions changed. The focus begun to look at how contemporary (gender) security discourse was constituted by feminist and women's NGOs in Serbia.

at R. Bhaskar 'On the Ontological Status of Ideas' Joumal for the Theory of Social Bebatiour, Vol. 27, No. 2-3 (1997), p. 139. 
The narrative of ontological moments does not stop there. It is important to realise that "we adapt an ontology... that depends on a progressive linear notion of time... they 'are' because they have a history in time, but at the same time separate from that history'. ${ }^{85}$ Consequently, the very constitution of (gender) security discourse has a complex temporal dimension. In part, this is because security discourse relies upon a series of perceptions outlined by perceived insecurities woven into the past and present: 'security lies in things hoped for and planned for... security is in large part [a] futures perception'.86 This is especially apparent when examining the security discourse of NGOs, which, generally speaking, are participatory organisations embodying a set of political objectives that members believe will achieve a better future. As such, a set of analytical strategies was adapted, to allow me to play with the multiple and various - and yet, simultaneous - temporalities embedded within security discourse. Escaping a purely chronological framework enables analysis to move across and around a temporal terrain to incorporate pasts, presents and futures in making the political assumptions of NGOs apparent.

Hence, one of the themes of this thesis is the notion of time and temporality, which is primarily apparent through the analytical strategies selected and deployed to understand discourse. These strategies form the focus of discussion in the following chapter. While discussions of time and temporality are not always apparent throughout the thesis, issues around time and temporality are ever-present in the construction of issues. Even the title of the study reflects a temporal uncertainty: "post-conflict" is rendered unstable. Is Serbia currently a post-conflict zone? Has the bound space of Serbia ever been a post-conflict zone? How do "we" know when Serbia is no longer a post-conflict zone? In other words, the title reflects an uncertainty about the temporal (and spatial) dimensions of "post-conflict" which is reflected throughout the text of feminist and women's NGO activists. Through writing with an awareness of the unfixed nature of time and temporality, it is partly my aim to challenge ways of thinking about time in our analysis of international politics.

${ }^{25} \mathrm{~J}$. Edkins Trauma and the Memury of Politics (Cambridge University Press, Cambridge, 2003), p. 14.

"6uotation retrieved from B. A. Reardon Women and Peace: Feminist Visions of Global Secwrity (State University of New York Press, Albany: New York, 1993), p. 22. 
PART ONE

\title{
GENDER POLITICS AND SECURITY DISCOURSE
}

\author{
UNIVERSITY \\ OF SHEFFIELD
}

LIBRARY 


\section{CHAPTER ONE.}

\section{TRACING THE POLITICS OF “GENDER SECURITY”.}

Discourses of gender security are formed by the personal-political imaginations of actors seeking to practice gender security. Personal memories, experiences, hopes and dreams merge with - and shape - political life, struggles, ambitions and history: forming an imagination. Imaginations conjure up a text about our world: guiding images of our world, shaping senses of our world, invoking conceptualisations of our world. Imaginations need not necessarily be something that has happened: imagination also embodies hope. This perception is critical when exploring advocacy work, where much political practice is concerned with hope for change. Understanding the importance of personal-political imaginations gives the classic standpoint feminist insight that the personal is political' an element of contingency, exposing antagonisms. The best way of appreciating the various configurations of "gender security" that exists within feminist and women's NGOs in Serbia is to trace the personal-political imaginations of activists. These personal-political imaginations reveal how, and why, activists form a particular perception of "gender security" and the ways in which these perceptions are translated into practice.

Making sense of the connections between the personal and the political requires consideration of time and temporality. This draws upon the poststructural perception that discourses operate within a specific temporal (and spatial) context. While discourses have a temporal specificity, they are also made up of continuities and changes, memories and hopes for future directions. That is, the gender security discourse of activists is located within one specific temporal moment. Within this specific moment, the discourse is also connected to other moments, including memories and perceptions about the past, as well as future hopes. Temporality is an intrinsic element of NGO practice: the political positions adapted by NGOs generally refer to a wish to alter (or retain) something in the future, in response to a perceived problem located in the past or present affecting these future hopes. When "reading" the security discourse of activists within feminist and women's organisations, an awareness of the forces of multiple temporalities within the discourse formed by personal-political imaginations of activists enables deeper problematisation of gender security discourse and its effects. 
This chapter aims to delineate the ontological and epistemological influences shaping interpretation, understanding and presentation of knowledge in this thesis: it is intended as an articulated 'context' to judgements about 'how best to go about finding out about the world'.1 This perspective recognises that the collection, retrieval and analysis of knowledge are subject to ontological, normative and sociological (inter)subjectivities that play a part in framing and guiding the research agenda and processes. In essence, research is not a value-free enterprise. Investigators make choices which inform and frame the "findings". The chapter begins with an outline of my own feministpoststructural ontology and epistemology, as it is these normative ideas that guide and frame my questions, concerns, research and analytical strategies. Attention then moves to a discussion of the research process which formed a text enabling analysis of personal-political imaginations. For this thesis, data collection included six months of field research in Serbia and Kosovo. Translating these fieldwork encounters and experiences into knowledge requires a clearly specified set of analytical strategies. $^{2}$ The remainder of the chapter exposes the analytical strategies used to analyse and make sense of the gender security discourse of NGO activists in Serbia, paying particular attention to notions of discourse and temporality.

\section{FORMING AND INFORMING TEXTS.}

Understanding some of the personal-political imaginations of activists requires a text to be formed. A text is more than merely a written document: rather, the social and political world is a text which is contextualised through intersubjective assumptions. This follows Derrida's line of thinking that 'there is nothing outside of text [there is no outside text]'. ${ }^{3}$ The "real world" does exist: but it is a world constituted through 'supplements, substitutive significations which could only come forth' in a chain of differential references'. ${ }^{4}$ Even at the point of origin, there is a supplement at the source: our world is made. To this end, it is important to understand how the "text" which is analysed in this study has been formed and informed. This section begins by outlining my own feministpoststructural ontology and epistemology affecting the selection of research questions, agendas and concerns: critical in shaping how "gender" is thought about in the formation of a text, and how a particular perception of "gender" informs analysis of a text. Attention then moves to a description of various fieldwork encounters in Serbia and Kosovo forming much of the text utilised in this study.

\footnotetext{
1 First quotation from S. Harding 'Introduction: Is there a feminist method?' in S. I Iarding (ed.) Feminism and Melbodology (Indiana University Press, Bloomington and Indianapolis, 1987), p. 3. The second quotation is retrieved from I. Shepherd Gender, Violence and Securigy, (Zed Books, London, 2008) p. 16.

2 T. Jacoby 'From the Trenches: dilemmas of feminist IR ficldwork' B. A. Ackerly, M. Stem and J. True (eds.) Iieminis/ Methodologies for Intemational Relations (Cambridge Unjversity Press, Cambridge, 2006), p. 153

${ }^{3}$ J. Derrida Of Grammatology (The Johns Hopkins University Press, Baltimore and London, 1997), p. 158.

4 Ibid., p. 159.
} 
Finally, this section discusses the notion of multi-sited ethnography as a research process affecting my understanding of personal-political imaginations of activists.

\section{Ontology and Epistemology: Feminist Poststructuralism.}

Feminist approaches to International Relations (IR) generally 'materialises as something very much like a "fault-line", constantly threatening to generate fissures and fractures to upset the status quo by rendering apparent the illusion of secure foundations'.5 Feminist ontology (perspective of "reality") tends to be primarily concerned with gender, and how gender shape the 'social relations in which individuals are embedded in, and constituted by', specifically 'historically unequal political, economic, and social structures'.6 As a consequence, feminist IR focuses upon a broad range of issues and concerns, frequently presenting challenges to apparently "traditional" state-centric and elite visions of IR. Fears abound that feminist IR is 'the study of women in the international system [that] seems to be designed to turn our attention away 'from the state and its power as a unit of analysis' to the needs and interests of women as 'an identity group'? Kimberly Hutchings argues that these perspectives are rather simplistic, possibly based on 'orthodox ideas about both knowledge in general and what counts as knowledge in international relations in particular'. ${ }^{8}$ Feminist IR confronts questions about what is counted as knowledge within IR, destabilising the status quo. Much of the challenge to the status quo is done through asking questions about gender. Feminism has an ontological and epistemological dedication to understanding the nuances of gender and the impacts that this may have on social, political and/or economic processes and patterns.

The 'concept, nature and practice of gender' is key to feminist theory. ${ }^{9}$. Gender can be understood in several ways. Jennifer Heeg Maruska draws upon Peter Beckman's and Francine D'Amico's work to conceptualise gender as-difference and/or as-power.10 Gender-as-difference maintains 'the binary

\footnotetext{
'M. Zalewski 'Do We Understand Each other Yet? Troubling Feminist Encounters With(in) International Relations' The British Jowrmal of Politics and Intemational Relations, Vol. 9, No. 2. (2007), pp. 302 -3.

6]. A. Tickner 'Feminism meets Intemational Relations: Some Methodological Issues' in B. A Ackerly, M. Stcrn and J. True (eds.) Feminist Melhodologies for Intermational Relations (Cambridge University Press, Cambridge, 2006), pp. 24 - 5.

' C. Coker, cited in K. Hutchings 'The Personal is Intemational: Feminist Epistemology and the case of international relations' in Knosing the Difference: Feminist Perppectites in Epirtemology (eds) K. Lennon and M. Whitford (London, 1994), p. 149.

- Ibid., p. 151

${ }^{9}$ M. Zalewski "Well, What is the Feminist Perspective on Bosnia?" Intermational Affairs, Vol. 71, No. 2 (1995), pp. 340.

10 J. H. Maruska 'Feminist Ontologies, Epistemologies, Methodologies, and Methods in Intemational Relations'. The Intermational Simdies Engylopedia. R. A Denemark (ed.) (Blackwell Reforence Online, 2010) wwwwisicompundium.com [accessed 30 March 2010]
} 
between sex and gender, men and women, and femininity and masculinity"11 In contrast, gender-aspower 'reveals the power relations within and between societies, and is able to describe the historical roots and eventual outcomes of the public-private divide', challenging the binaries present in the gender-as-difference perspective. ${ }^{12}$ Maruska draws upon the example of wartime rape to demonstrate the different impacts that these ontologies have upon research;

'This ontology [gender-as-difference] would be appropriate if, for example, we were examining the number of instances in which rape was used during wartime. However, it would not uncover the deep-seated power relations that make rape into a viable (if brutal) battlefield strategy: its demoralizing effects, its devastation on society beyond the actual act... when examining wartime rape [from the perspective of gender-as-power], we would look into the meaning of motherhood, of community, of human relations to see how the act of rape in wartime is a power play that transcends the individuals involved, and affects the victimized society more broadly.'13

How "gender" is thought about affects the ontological and epistemological ambition of various feminist approaches to IR.

If a minimal definition of feminism is a concern with some aspect of gender inequality, then a range of possible approaches meet this requirement, including Liberal, Socialist, Critical and Poststructural feminist perspectives. ${ }^{14}$ Liberal feminism highlights how the Liberal pursuit of natural rights regarding individual freedom and justice has been skewed in favour of men: an error arising out of sexist beliefs that can be corrected by giving additional consideration to women and protecting female individualism. Socialist feminists take issue with the existing unequal class and gender structures in the world, highlighting female economic and social issues that arise out of the experiences of capitalism. While 'all feminist projects seem to share... [a] critical ontology'15, by isolating Critical Feminism as a particular ontological and epistemological approach, I aim to describe the specific call made for IR to expand its referent object to include 'women' and topics not normally considered within IR. Poststructural feminism is sometimes thought of as the 'bad girl' of feminist IR because of its refusal of a singular feminine subject and espousal of a politics of undecidability: a position that

\footnotetext{
11 lbid.

12 lbid.

13 lbid.
}

14 These typologies miss out many important approaches, including radical and post-colonial feminism. The aim here is to highlight how poststructural feminism is different, not to provide a comprchensive overview to feminist IR theory. Sce ]. Steans Gender and Intemationul Relatione (Polity, London, 2006), pp. 7 - 19, J. A. Tickner Gendering World Politics: Issues and Appraathes in the Past-Cold War Eina (Columbia University Press, New York, 2001), pp. 9-35, M. Zalewski Feminism after Postmodemism: Theorising Through Pruitice (Routledge, London, 2000) or C. Weedon Feminist Practice and Poststructuralist Theory (Blackwell Publishing, Malden, MA, 1997), pp. 13 - 19 for more explanations on various typologies.

13 Maruska 'Feminist Ontologies'. 
throws into doubt the possibility of a "feminist project". ${ }^{16}$ While ontological and epistemological purism rarely exists (for instance, my own approach includes elements normally ascribed to Critical feminism), this study is best described as an example of feminist-poststructuralism.

Feminism and poststructuralism share many affinities: both approaches require a significant amount of reflexivity, and both perspectives have a concern with issues about power and authority. ${ }^{17} \mathrm{~A}$ feminist-poststructural approach is committed to an exploration of both gender and language. This thesis exposes how the politics of negotiating "gender" shape interpretations and practices of gender security: that is, how the language of "gender" is operationalised in the practice of "gender security". As the analytical consideration about language occurs later on in this chapter - in the discussion about discourse and temporality - this section highlights the complexity of gender, and the impacts that "gender" has upon the framing, process and analysis in the research and production of this thesis.

Gender is a more complex phenomenon and essence than is often realised. This has been described by Georgina Waylen in her analysis of key critical International Political Economy (IPE) texts. Critical IPE

\begin{abstract}
'does not mention gender except in passing or engage with any of the gendered political economy debates and research, despite feminist attempts to engage in dialogue. At the moment, only an occasional token article or a few references to women are included within critical IPE. Most analyses therefore remain gender-blind and over-simplistic, oblivious to the complexity of the situations they analyse'. ${ }^{18}$
\end{abstract}

Critical IPE misses gender nuances because 'even those critical analysts who think that they are using gender as an analytical category are actually only talking about the role of women actors in one context'. ${ }^{19}$ Similar criticisms can be made about (critical) IR as well. ${ }^{\circ}$. While it is possible to have a

\footnotetext{
${ }^{16}$ Weber, C., 'Good Girls, Little Girls, and Bad Girls: Male Paranoia in Robert Keohane's Critique of Feminist International Relations' in Millennium: Jourmal of Intermational Studies, Vol. 23, No. 2. (1994) pp. 337 - 49.

${ }^{17} \mathrm{~S}$. N. Hesse-Biber 'Feminist Research: Exploring the Interconnections of Epistemology, Methodology and Method' in The Handbook of Feminist Researrb; Theory and Praxis S. N. Hesse-Biber (ed.) (SAGE Publications, London, 2007), p. 11.

18 G. Waylen 'You still don't understand: Why troubled engagements continue between feminists and (critical) IPE' in Revies of Intemational Sindies, Vol. 32, No. 1 (2006), p. 145.

19 Ibid. p. 151.

20 For instance, while Ken Booth (who I describe as a Critical Security Studies scholar in chapter two) is sympathetic to feminist works, and frequently insists upon the inclusion of women in his emancipatory theory of world security, his focus is very much on women who suffer human rights abuscs, i.e. a women-as-victims perspective - rather than highlighting a more complex picture of gender. See also Maruska 'Feminist Ontologies', where it is argued that 'while nonfeminist IR scholarship may take seriously the rights of women (and children and men), it generally does not focus attention on the complexities of gender as a social and relational construction'.
} 
non-feminist gender theory ${ }^{21}$ : central to the feminist project is an in-depth, rigorous and nuanced comprehension of "gender" that recognises the intersections between gender and power. To analyse intersections between gender and power, this study is inspired by the understanding that gender is an inherently unstable and unfixed notion which functions as fixed. This perception follows Judith Butler, who unpacks how 'gender operates as an interior essence that might be disclosed, an expectation that ends up producing the very phenomenon that it anticipates'.22 That is, a construction of "gender" relies upon a specific set of codes governing the limits, opportunities and historicity of masculinity and femininity. Anticipation of 'bodily and bchavioural selves' in the (re)production of a gender is made "natural" or "cultural", and consequently, fixed.23 To make clear the nuances and complexity of "gender", I expose how "gender" intersects with power by recognising how gender is "made", a notion that matters because the specific construction of "gender" guides and informs social, political and economic actions and outcomes.

For poststructural feminists, understanding that 'the meaning of gender is both socially produced and variable between different forms of discourse', momentarily fixing "gender", enables analysis. ${ }^{24}$ This perspective is inspired by Christine Sylvester's insistence that "gender" should not be thrown out of 'even false homes before searching through their spaces for hidden treasures', 25 Sylvester highlights a significant tension within feminist-postmodernism, ${ }^{26}$ where the feminist heart 'does not want to vaporize the experiences of people who cannot afford to distance themselves from their assigned homes, or who...draw inspiration for transformed identity and practice from gender identity and solidarity'. ${ }^{27}$ In contrast, the postmodern heart does not want to "revel in gender homes because they may not really exist as meaningful foundations for the future'.28 The struggle to negotiate, consider and hold apparently mutually distinct ontological beliefs remained throughout the research and

${ }^{21}$ See for example R.C. Carpenter 'Gender Theory in World Politics: Contributions of a Nonfeminist Standpoint?' Intemarional Siudies Review, Vol. 4 (2002), pp153 - 165, and the subsequent discussion edited by Terrell Carver 'Gender and Intemational Relations' Intemational Siwdies Retriew, Vol 5, (2003), pp. $287-302$.

${ }^{22} \mathrm{~J}$. Butler Gender Trouble (Routledge, London, 2007), p. xv.

${ }^{23}$ T. Carver 'Gender/Feminism/IR - The Forum: Gender and International Relations' Iniemational Simdies Retiew (2003), Vol. 5, p. 289.

24 Weedon Feminist Practice and Postrtructunutist Theory, p. 22.

${ }^{2 s}$ C. Sylvester Feminist Tbeory and International Relations in a Pastmodern Ena (Cambridge University Press, Cambridge, 1994$)$, p. 215.

${ }^{26}$ I recognize that there is a difference between postmodemism and poststructuralism. Postmodernity is a concern with the condition of the "post-modem" (i.e. after modernity) world, which assumes a temporal break with modemity. Poststructuralism is "one of the interpretative analytics that critically engages with the production and implication of these transformations'. In some cascs, including J. Der Derian and M. J. Shapiro (eds.) Intemational/Intertextual Relations: Postmodem Readingr of World Politics (1989), publishers have insisted upon 'postmodern' in the title. See D. Campbell 'Poststructuralism' in T. Dunne, M. Kurki and S. Smith (cds.) Intermational Relations Theories: Discipline and Diterrity (Oxford University Press, Oxford, 2007), pp. $211-212$ and 227. I use postmodernism in this context purely because this is the label that Sylvester uses, but the analytical approach that Sylvester outlines has a strong affinity to poststructuralism.

${ }^{27}$ Sylvester Feminist Theory and Intemational Relations in a Postmodem Era, p. 215.

29 lbid. 
writing of this study. ${ }^{29}$ I do not aim to reconcile them, but rather, 'negotiate this paradox' through giving "gender" "flesh while maintaining analytic distance between [gender] as heuristic devices, and the lived, material reality in and through which they echo and are refracted'..$^{30}$ Gender is a concept momentarily fixed, for cultural, sociological and/or political reasons, a "fixing" whi9ch enables a search for 'hidden treasures', illuminating something about gender.

Gender is treated as 'a noun, a verb and a logic' shaping the security discourse of activists in Serbia. ${ }^{31}$ That is, gender is a tangible and nameable object, an action or state of being, and a set of ideas and explanations. This conceptualisation of gender highlights the multifarious roles that a description of "gender" takes on, and the almost insidious effect of "gender" on our world. Gender is an object in the sense that the object of study is "gender security" and "women's and feminist organisations": both objects of study incorporate a concern with "gender" in some way. Gender is an action and/or state of being: activists of feminist and women's organisations are guided by a concern with gender, and it is their own gender politics that inform actions. Gender is a logic a complex of explanations and practices arranged in such a way as to constitute a specific set of relationships that make up a particular political and social perspective, which is then articulated or represented. ${ }^{32}$ Perspectives about "gender" depend upon specific and particular social, ontological, historical and spatial configurations constituting logics of "gender". As will be noted in chapter three, gender logics in Serbia have been deeply affected by political perspectives towards the wars of the 1990 s. The way that the object, action and logic of gender form a coherent gender position is described as gender politics throughout this study. These gender politics profoundly and deeply affect the construction and practice of gender security in Serbia.

A duality runs throughout this study. First, this thesis is ontologically and epistemologically informed by feminist approaches and a curiosity about how "gender" operates and matters. Research questions are based around a concern with exploring various configurations of gender security. Much of the knowledge is derived from actors with a feminist or gender concern, and the majority of the academic and grey literature drawn upon is feminist or feminist-friendly. Second, this study is on gender: that is,

20 Fieldwork and reflection notes from 26 March 2008, 12 April 2008 and 6 November 2009.

3) First quotation Sylvester Feminist Theory and Intemalional Relations in a Postmodem Era, p. 215., second quotation K. Jones cited in Sylvester Feminist Theory and Intermational Relations in a Postmodem Eira, p. 215.

31 This perception of gender is the driving force behind L. J. Shepherd (ed.) Gender Malters in Global Politics: A Feminist Introduction to Intermational Relations (Routledge, London, 2010).

32 J. Glynos and D. Howarth Logics of Critical Explanation in Social and Polisical Theory (Routledge, London, 2007), pp. 133 - 164 and L. J. Shepherd 'To save succeeding generations from the scourge of war': the US, UN and the violence of security' Review of Intermational Studies Vol. 34, No. 2 (2008), p. 294. 
the gender politics of women's and feminist NGO activists is investigated. This focus means that this thesis is an analysis of feminism and gender politics. Recognising the connections between "gender" as a discourse and the political identity of activists is at the heart of this thesis. The commitment to making sense of the nuances of gender politics that shape, mould and affect actors and actions within feminist and women's organisations in Serbia ensures that interpretation, analysis and critique is concerned with critically explaining and problematising the ontological and epistemological basis for how gender security is (re)constructed amongst NGO activists. As such, this thesis is simultaneously an investigation and analysis of feminism and gender politics, as well as being informed and guided by a feminist ontology and epistemology.

\section{Methodology}

Ontology, epistemology and methodology are interlocked in a mutually dependent relationship requiring subjective political, sociological and ethical considerations and choices for the researcher. Recognising the radical contingency of objectivity that is ever-present in methodological choices, this section exposes the methodological processes informing this study. Methodologies - how we "get at" knowledge - serve a purpose, as without [an] appropriate methodology we cannot do what we want to do'.33 In this study, knowledge is "got at" by building a text from which personal-political imaginations of activists can be interpreted. Making sense of bow knowledge is collected is crucial in seeking 'to understand and unpack the overlap between knowledge/power'. ${ }^{34}$ Data collection is a value-laden and (inter)subjective practice. Much of the data used in this thesis was collected and produced through six months of formal research in Serbia (February - August 2008) and additional follow-up trips in June and September 2009. As Tami Jacoby recognises, 'fieldwork involves a séries of methodological choices that allow the researcher to enter briefly the lives of those being researched and to generate knowledge by observing behaviour, asking questions, and analysing data'. ${ }^{35}$ The following paragraphs depict the processes and considerations that formed the text enabling analysis of how personal-political imaginations form gender security discourses.

To expose explicit and implicit configurations of security discourse within policy agendas and debates held by activists, a web of intertextual knowledge drawing upon a wide range of material was formed. It is rare for feminist poststructualist work in IR to base a significant proportion of their work upon

\footnotetext{
${ }^{33}$ R. Duelli-Klein 'How to do what we want to do: thoughts about feminist methodology' in R. Duelli-Klein and G. Bowles (cds.) Theories of Women's Studies (Routledge, London, 1983), p.101.

${ }^{34}$ L. Stanley 'Methodology Matters' in V. Robinson and D. Richardson (eds.) Introducing Women's Studies (Palgrave, Basingstoke, 1997) , p. 198.

${ }^{33}$ Jacoby 'From the Trenches', p. 153
} 
interpreting field research. However, as Lene Hansen suggests, the need to cast a wide net is important when marginal discourses are involved - such as grassroots NGO discourse - as a detailed knowledge of the case study is needed. ${ }^{36}$ Details of the personal-political imaginations of activists were gathered through a methodology best described as multi-sited ethnography, an approach borrowed from Carol Cohn. ${ }^{37}$ Perceptions, knowledge, interpretations and understandings of security within NGO activists were gathered from a wide range of sources, including interviews, documents, websites and participant observations. A wide net was cast because this study deliberately seeks to understand the effects that personal-political imaginations has upon configurations of gender security. For example, when seeking to understand the responses of a NGO to UNSCR 1325 , merely examining the written documents published by the NGO would have limited opportunities for in-depth examination of how individual activists in the group articulated security, and ways these personal senses of security related to explicitly represented meanings of security put forward by the group.

Conducting in-depth interviews was critical in making sense of some of the personal-political imaginations driving advocacy work. I carried out the majority of my overseas field research in Serbia and Kosovo between February - August 2008. Over six months, I conducted 66 recorded, loosely semi-structured individual or group interviews with 86 feminist and women's NGO activists, representatives from feminist international donor organisations and international institutions working with feminist and women's NGOs. All interviews were transcribed by research assistants. Thirty of these interviews were conducted partially or all in Serbian, with translation support by native Serbian speakers. These translators also transcribed these interviews into English, closely following the sentence structure of the speaker. ${ }^{38}$ Interviews lasted between forty minutes and four hours, depending upon the respondent and the location of the interview. ${ }^{39}$ Thirteen follow-up interviews to fill identified gaps were carried out in Serbia during June and September 2009. Appendix A, has a table of details for all recorded interviews conducted. In Kosovo, my interviews were limited to the

\footnotetext{
${ }^{36}$ L. Hansen Security as Practic: Discourse Anatysis and the Basnian War (Routledge, London, 2006) p. 63. There are examples of feminist poststructuralist work in international relations drawing upon a large number of interviews, including. S. Parashar Women, militancy, and Security: the South Asian Conundrum' in L. Sjoberg (ed.) Gender and Intemational Security: Feminist Perspectives (Routledge, London, 2009), P. Higate and M. Henry Insecure Spaces: Peacekeeping, Poster and Pefformance in Haili, Kasovo and Liberia (Zed Books, London, 2009) and Sylvester Feminist Theory and Intemutional Relations in a Postmodem En, especially chapter five. However, there is room for a serious consideration of how to conduct poststructuralist feminist research in international relations drawing heavily upon field interviews: many of the problems and subjectivities of the research methodology are rarely invoked.
}

${ }^{37}$ C. Cohn 'Motives and Methods: using multi-sited ethnography to study US national security discourses' in B. A. Ackerly, M. Stern and J. True (eds.) Femintist Methodologies for Intermational Relations (Cambridge University Press, Cambridge, 2006), pp. 91 - 107.

38 When a word proved particularly tricky to translate, this would be discussed. It was in those discussions that the complexity of "security" in Serbian was revealed. These issues are discussed in more detail in chapter four.

19 Generally, interviews held outside of Belgrade were longer and more informal. In some cases, I would spend the whole day with participants, who would show me around the town/village, introduce me to their neighbours, take me to their favourite coffce shops or a local restaurant. 
capital, Pristina, as my primary objective in Kosovo was to collect detailed information for part of a case study. Interviewees were identified through a combination of targeted and identified selection and 'snowball sampling'.40 This meant that interviews were conducted with participants who were assumed (by other interviewees or myself) to have knowledge about feminism and security in Serbia, insofar as knowledge can be equated with experience.

While recognising that interviews do not capture a "truth" of experiences, they do form a significant source of data from which narratives are interpreted and deconstructed. ${ }^{41}$ There is a strong, and problematic, implication that 'qualitative work, particularly the semi-structured or unstructured interview... is quintessentially feminist'.42 Interviews were not conducted because they are thought to be a "more feminist method". Rather, the interviews for this thesis were intended to fulfil two purposes. First: to establish a detailed and wide-ranging snapshot of feminist organising in Serbia during the late 2000 s, to update the existing literature dominated by analysis of the conflict periods of the 1990s.43 Virtually all the interviews conducted with feminist activists and representatives from women's NGOs provided me with the benefit of their personal experiences and involvement in Serbian feminist and women's organising. Interviews offered an insight into the effects that agendas, funding, and local contexts had upon the politics of women's and feminist organising in Serbia. This contextual understanding allowed an appreciation of the long-term impacts of war, political violence and repression: a major theme underpinning analysis of security discourse in this thesis.

Second; interviews enabled an appreciation of some feminist discourses around conceptualisations of security to be vocalised and expressed, allowing me to unpack ways that these articulations of security are product/productive of particular policy agendas that form the focus of this thesis. Elements of these understandings regarding security were present in all interviews, but with selected people working in relation to feminist-pacifism or SALW issues in domestic violence, finer details of the discursive processes and working of "security" in relation to these case studies were sought. The way in which security is discursively constructed relates to the gender politics of individual activists, and his/her perspectives about "post-conflict" in Serbia; an intersection that is explored in-depth in

\footnotetext{
${ }^{40}$ Cohn 'Motives and Methods', p. 100.

"B. D'Costa 'Marginalised Identity: New Frontiers of Research for IR' in B. A. Ackerly, M. Stern and J. True (eds.) Feminist Methodolugies for Internutional Relutions (Cambridge University Press, Cambridge, 2006), p. 140.

$\$ 2$ Quotation retrieved from M. Manyard and J. Purvis 'Introduction: Doing Feminist Rescarch' in M. Manyard and J. Purvis (cds.) Reseanbing W'omen's lites from a lieminist Perspective (Taylor and Francis, London, 1994), p. 3. See also M. Caprioli 'fieminist IR Theory and Quantitative Methodology: A Critical Analysis' Intemational Sindies Retriew, Vol. 6 (2004), pp. 253 - 69.

43 A key exception to this gap is Cynthia Cockbum's work, in particular From W'ben W'e Sland. War, W'omen's Actiism and Feminist Anatyis (Zed Books, London, 2007).
} 
chapters four, five and six. Frequently, several activists from one organisation were interviewed, enabling multiple individual voices to be heard and an understanding of the relationship between the beliefs of the individual activist and stated aims of the NGO.44 Together, the interviews conducted formed an intertextual web for analysis and interpretation of significations, articulations and representations of security, and how security discourse is product/productive of a specific policy agenda.

Throughout interviews, an important consideration was the politics of location and representation. My location as a non-Serbian researcher with no prior contact with Serbia cast me as an outsider, assumed to have no prior knowledge about Serbian history, culture or politics. ${ }^{45}$ This image was encouraged, as it meant that participants were more likely to connect their stated political beliefs with some sort of contextual information. This context provided me with insights about what interviewees considered as feminism, what they believed shaped attitudes towards feminism, and personal stories about war and its impact upon their political activism. My outsider status meant that interviewees provided me with context about their personal significations surrounding security: for example, instead of merely highlighting economic security, activists would then tell me stories and elaborate on the local situation - providing me with an explanation to analyse. 46 Intersecting with my perceived position as an "outsider" is the interviewee's own politics of representation, which they are self-consciously negotiating throughout the interview. Research agents are not merely responding to agendas and questions of researchers, but are shaping their own agenda of bow they want to be represented.47 This is a significant issue given that feminist and women's organising in Serbia is

\footnotetext{
4 Gencrally, activists within Belgrade-based NGOs were interviewed individually, while activists based outside Belgrade tended to be intervicwed together. While the group interviews - which tended to be much longer and more relaxed - allowed for immediate internal discussion and agreement about the positions of the group towards feminism, security, political responsibility and so on, as well as reaching a more accurate factual recall of dates or funding bodies, I insisted that I wanted to hear individual accounts at the start of these group interviews, and for the most part, activists respected this and ensured that their colleagues had said all that they wanted to say before talking themselves. Belgrade-based organisations tend to have more funding than groups outside the capital, and so had published much of the organisational views in Serbian and/or English, so material about the shared views of Belgrade-based groups did not need to be collected via interviews, although interviews were revealing in the extent to which activists agreed with the organisational perspective.
}

49 I have no family, cultural or religious connections to Serbia, and prior to 2008 , no ties of friendship. However, I have a long-term interest in southcastern Europe: my undergraduate dissertation (Sheffield, 2005) looked at the impact of feminist organising upon discourses about genocidal rape in Croatia and Bosnia-Herzegovina; and my MA dissertation (Shefficld, 2006) looked at the way that feminism, war and nationalism were discursively interlocked amongst Belgrade feminist organisations during the 1990s. These interests all played a factor in the selection of my thesis topic.

46 I noticed a disparity at times in my Serbian and English interviews. My interviews conducted in Serbian were supported by a native Serbian research assistant, and as such, sometimes participants would say formulations such as "oh, but you understand what I mean, you have also lived through this" directly to my research assistant. As I gave my local rescarch assistants in Serbia a high degree of autonomy in terms of asking questions during interviews, the usual response was "well, perhaps it would be hclpful for Laura to know what you mean by that", almost accidently implicitly reminding the participants of my "outsider" status. Curiously, 1 rarely had to push for more detail in my interviews conducted in English: hence my belief that my presence as an "outsider" meant that I gathered very different responses, with a much higher level of contextual explanation.

17 J. Lai 'Situating Locations: The Politics of Self, Identity and "Other" in Living and Writing the Text' in S. Hesse-Biber and R. Lydenberg (eds.) Feminist Approaches to Theory and Methadology: An Interdisciplinay Reader Oxford University Press, Oxford, 1999), p. 122, and Jacoby 'From the trenches', p. 162. 
marginalised and frequently derided publically as "ridiculous".48 Often, I would be reminded that my work was potentially important in giving international legitimacy to the political perspectives of feminists in Serbia.49 The politics of location and (self)representation mean that interviews are a formulation based upon interactions between the researcher, interviewee, research assistants and broader local, national and international contexts. As such, interviews are not treated as sources of authority, but rather, knowledge and experiences forming personal-political imagination which I interpret.

Relevant written documents were used to make sense of the discourses surrounding articulations and representations of gender security. During my formal data collection period, pamphlets, reports, information booklets, press releases and other written materials were given to me by interviewees, which provided sources that I would not have been able to retrieve elsewhere, alongside materials considered confidential - such as funding bids. I used Belgrade University's Gender and Women's Studies Centre, which has a library and documentation centre holding relevant materials. ${ }^{50}$ Many NGOs and international institutions have websites in English and Serbian that were referred to before, during, and after the formal data collection period. Of all the NGOs considered in this thesis, Women in Black have the strongest source of documentation. In part, this is because they are an NGO operating internationally, primarily concerned with political campaigning, while other NGOs, working on other issues, such as domestic violence, devote much of their energies and funds to provision of legal advice, shelters and so on. As a consequence, part of the activity profile pursued by Women in Black is the publication of written material in several languages: it is an important way for them to get their highly politicised message across.

The use of written sources is frequently acknowledged to have complexities in relation to interpretations of the researcher and issues about neutrality and authorship in the (re)production of the document. While I regard these considerations as important, I also consider them to be unavoidable: rather, it is better to reflect upon how the documents used were interpreted. In terms of a research methodology, written and spoken sources were used for exposing the construction of a broader political concept, rather than for content analysis. Content analysis refers to numerical

\footnotetext{
46 See chapter three for a detailed analysis of the social context affecting how feminism is perceived in Serbia.

49 Field notes 24 March 2008, 26 March 2008, 5 June 2009, 24 June 2009. During my last intervicw Staśa Zajović [coordinator, Women in Black - Serbia (Belgrade, 18 September 2009)], urged me to consider my position and use my data responsibly.

50 The centre was in the process of cataloguing while I was there. While the matcrial was selected (it needed to have something to do with gender) and was roughly organised (for example, there would be a bookcase relating to Women in Black, or a shelf of materials for a specific course), I was required to manually search through items within those roughly organised categories to identify anything I felt related to security or my case studies. A photocopy was made for later analysis.
} 
measure of specific language, a method which risks losing sight of the overall significance of a communication for its component parts. Discourse analysis looks at the inferences, situation, context and intertextuality in the production of a specific discourse or/and policy.51 As such, scanning documents for specific mentions of "security" - or the Serbian translation, bezbednost - was merely a starting point.52 The construction of "gender security" within documents was related to the personalpolitical imaginations of activists to highlight how these perceptions shaped configurations of gender security. To make sense of the ways that gender politics and notions about "post-conflict" affect gender security discourse, it is necessary to construct a broader intertextual web, by locating these documents within interviews and observations.

Epistemological and methodological priority was given to written documents produced in response to gender security concerns; namely the Draft Resolution on Women, Peace and Security and the SALW in domestic violence report published by SEESAC. ${ }^{53}$ Discussed in chapter five, the Draft Resolution on Women, Peace and Security, produced by Women in Black is a critical vehicle for analysis, as it is a public articulation of how the NGO interprets gender security within UNSCR 1325. In chapter six, a report published by an international agency (SEESAC), connecting small arms and light weapons to domestic violence, is taken as the discursive nucleus for analysis, as the report was produced in response to gender mainstreaming demands of UNSCR 1325. Both documents were considered to be central because both made an explicit reference to "security", making it is possible to explore how "security" has been conceptualised. An intertextual web was then constructed around these documents, built initially from written sources mentioned within, and in relation to, these documents. I also followed up any written sources that interviewees indicated were important. Additionally, relevant written sources were identified by a degree of chance, in part because my formal data collection period took on elements of ethnography.

\footnotetext{
31 For example, Shepherd's Gender, Violene and Security looks at the discursive construction of gender, violence and sccurity within a particular document - UNSCR 1325, while D. Campbell's W'riting Security: United States Foreign Paligy and ibe Politics of Identity (Manchester University Press, Manchester, 1992) examines how "security" is discursively inscribed within official foreign policy proclamations within the United States.

32 This was done through searching relevant websites, or in a more time consuming fashion, searching by hand through public archival material. The objective was to identify specific articulations of "security" (or bezbednart): this method was highly revealing in the temporal occurtence of "security" as an explicit discourse. This understanding that "security" was explicitly articulated at a particular moment led to further investigation into the politics surrounding this specific discursive moment, which required a broader intertextual knowledge.

53 Women in Black 'Draft Resolution' in Women for Peace (Belgrade, 2007), pp. 187 - 189, M. Dokmanovic, Firearms Passession and Domestic Violence in the Westem Balkans: A Compantive Study of Legislation and Implementation Mechanisms (SEESAC, Belgrade, 2007).
} 


\section{Multi-sited Ethnography}

Ethnography is a method normally associated with anthropology, but the commitment to 'going out and getting close to the activities and everyday experiences of other people' can be insightful to research in international relations. ${ }^{54}$ Recent anthropological research has examined conceptualisations of societies and cultures as dynamic and in a constant state of flux, sharpening the focus on 'how everyday life is linked to, and changes in relation to, political processes'.55 The ethnographic approach is especially useful in formulating various understandings of the complexity of a contested concept, like "gender security", a concept with multiple meanings across and within various cultural, social and political contexts. I use multi-sited ethnography as a concept to explain how my data was interpreted: the approach recognises how my interviews were located within a context that I was living in, and therefore interpreting. Layers of multi-sited and situated knowledge accumulated from six months of research, reflection and living in Serbia moulding my research outcomes. Immersion in the field still requires subjective choices, and as such, it is critical to stress that 'ethnography is not a method: rather it is a theory of the research process'.56 This approach recognises that 'ethnography provides interpretation and explanation by strategies of contextualisation'.57

Interpretations and explanations arise from fragments of knowledge that relate to each other: in other words, knowledge is derived from multiple sites. The concept of multi-sited ethnography was developed by Carol Cohn to describe two decades of work on the role of gender in shaping US national security paradigms, policies, and practices. ${ }^{58}$ To make sense of the way gender occurs in national security discourse, Cohn draws upon participant observation of defence and military intellectuals at their training institutions, conferences, lectures and seminars, interviews with civilian and military professionals involved in national security and relevant popular culture, including films, newspapers stories and radio transcripts. ${ }^{59}$ This method relies upon the 'juxtaposition and layering of what, [Cohn] found in different sites, in different contexts, with different constituencies', a method

\footnotetext{
54 L. B. de Volo and E. Schatz 'From the Inside Out: Ethnographic Methods in Political Research' PS: Political Science and Politics, 37, 2 (2004), p. 267. Quotation extracted from R. M. Emerson, R.I Fretz and L. L. Shaw Writing Eithnographical Fieldnotes (University of Chicago Press, Chicago, 1995), pp. $1-2$.

55 de Volo and Schatz 'I'tom the Inside Out', p. 268.

56 B. Skeggs 'Situating the Production of Feminist Ethnography' in M. Mayard and J. Purvis Researtbing Women's Lizes from a Feminist Perspestive (Taylor and Francis, Jondon, 1994), p. 76.

57 Ibid,

58 Cohn 'Motives and methods', p. 91.

${ }^{59}$ Ibid, p. 95 - 96.
} 
reflecting the approach I took during the consideration, research and writing periods of this thesis. ${ }^{60}$ A multi-sited ethnographic approach enables a (partial and perpetually incomplete) text to be built to trace the personal-political imaginations of activists, supporting insights into how gender security is configured.

During my research periods, I wrote detailed field notes, reflecting upon my interviews, my surroundings, conversations with people, and social and political events. My physical presence in Serbia enabled sporadic participant observation of public feminist activity and organising: I attended book readings, film screenings and performances, participated in protests, marches and remembrances (see Appendix A). I took photographs where possible, and made notes after each event, focussing on how activists publically portrayed their ideas. In June 2009, I was invited to a three day retreat and strategic planning meeting of the Women in Black network, an invaluable insight into the processes through which activists reflected upon political ideas and concepts. Discussions and meetings with academics in Belgrade and Novi Sad (sometimes working with feminist NGOs) provided simulating avenues to explore. Many interviews took place in the offices of the NGO, allowing me an insight into the space from which activists worked in, as well as daily office life. Reading Serbian media outlets, like B92, gave me a perspective on key reported issues in Serbian society. Even though many observations do not directly relate to my thesis, the perceptions that $I$ formed about my surroundings shaped interpretation of interviews and written documents.

The result is a multi-layered personal perception and response to the cultural, social and political context in Serbia. The goal of multi-sited ethnography is 'not holistic representation' of the world, but to allow for various windows, dots of understanding and perceptions that we join up within our own theoretical frameworks. ${ }^{61}$. These experiences and understandings provide an important means of building layers of what "security" and "postconflict" might mean on an everyday level. For example, informal conversations gave a better sense of what "post-conflict" and "transition" meant for people: visa problems, the cost of living in Belgrade, unemployment, experiences of the NATO bombings, war crimes, political attitudes towards Kosovo and the EU. All of these issues are related, in some way, back to the conflicts of the 1990 s in Yugoslavia, and provide an important insight into what people perceive as "post-conflict" problems that create a sense of insecurity. This approach seems to support the ambition of feminist research as a 'social interaction in its own right' supporting

60 lbid, p. 107.

of Quotation retrieved from G. E. Marcus 'Ethnography in/of the world system: The Emergence of Multi-Sited Ethnography' Annual Revies of Anthropology, Vol. 24 (1995), p. 99. 
understandings of the social world that we are located in.62 While in Serbia, I was never "out" of the research zone and as such, my "findings" are mediated through the social context in which I experienced in a particular temporal-spatial moment. ${ }^{63}$

Forming a text from which the personal-political imaginations of activists could be interpreted relies upon different layers and conjunctions of comprehension. The formal qualitative research methods through which security discourse is read, interpreted and analysed in this thesis are difficult to peel apart from the multi-sited ethnographic understanding developed over the course of preparing, researching and writing this thesis. Through a multi-layered research process, a partial, and perpetually incomplete, text giving insight into the personal-political imaginations of activists was formed, enabling analysis of various configurations of gender security.

\section{ANALYTICAL STRAGETY (1): DISCOURSE}

A key analytical strategy has been a concern with discourse and discursive formations. This section unpacks how poststructuralist conceptualisations of discourse and discursive formation influence analysis of personal-political imaginations in this thesis. First, the notion of discourse is explored, recognising discourses as systems of meaning-making.64 This highlights that "gender security" is constituted through a range of subjectivities and limitations. These subjectivities are forged through personal-political imaginations which are constrained and made possible by a discursive terrain where discourses of gender security are performed. Attention then turns to the perception that discourses are systems of meaning-making, stressing that there are several building-blocks that form a discourse and the effects of that discourse. That is, discourses are made up of a series of significations, articulations and representations that operate to support the performance of a discourse. These significations, articulations and representations are product and productive of the political-personal imagipations of activists, shaping the outlines of gender security discourse. Finally, this section outlines how discourses are explored in this thesis, illuminating a deconstructive mode of thought which functions as a key analytical strategy.

\footnotetext{
62 L. Stanley, TFeminist Praxis and the Academic Mode of Production: An Editorial Introduction' in Feminist Praxis: Researib, Theory and Eipistemology in Feminist Sociulogy, (ed). L. Stanlcy, (Routledge, London, 1990) p. 8.

63 These thoughts are echoed in Higate and Ilenry Insecure Spaces pp. 6 - 7.

64 The phrase 'a system of meaning-making' is inspired by Laura Shepherd's 'systems of meaning-production'. Sce Shepherd Gender, Violence and Security (Zed books, London, 2008), p. 20.
} 


\section{Discourses about Discoutse.}

There are several 'discourses about discourse', putting forward very different visions of what discourse analysis is about. ${ }^{65}$ Competing visions about discourse can be attributed to the ontological perspective taken about language, and the perceived relationship that language has to the social and political world. Discourse analysis can be a narrow enterprise concentrating upon how a discourse is used in an "effective" way. These approaches include content analysis, critical discourse analysis (CDA) or framing theory. Content analysis refers to the numerical measurement of a particular identified utterance. CDA, a method advocated by Norman Fairclough, places emphasis upon human agency and social structures to 'expose the way in which language and meaning are used by the powerful to deceive and oppress the dominated'.66 Framing theory is deployed by David Snow and Robert Benford in their analysis of how NGOs reshape political agendas. ${ }^{67}$ Framing theory presumes that actors construct a coherent frame (discourse) around which social movements cluster for specific purposes: discourse analysis measures the effectiveness of these frames, not how or why such frames are constructed. The three approaches that have been briefly outlined have their predominant concern with a measurable efficiency of a discourse, and assume that meaning is 'constant and identifiable through the discourse, rather than constituted by discourse'. 68

My interpretation of "discourse" rejects the notion that there is some kind of material reality. I see the world as constituted, that is, something which comes about, and where understandings are (re)produced and meanings are made. This does not mean that something does not exist, but rather, that the meaning or significance of an item, event, or concept is made. Marysia Zalewski illustrates this through describing the different meanings that can be fixed to a china container, which;

'can be a drinking utensil and so if it gets broken it may not matter very much. But the same object might be a container for the ashes of a dead loved one and as such the consequences of dropping it can be very different. If the 'dead one' were a king or god and the punishment for dropping the container were execution, the consequences would be extremely different.' 69

The specific social ontology expressed here contests the possibility that objects have a meaning independent from the discourse constituting the object. The perspective that meanings are

\footnotetext{
${ }^{6 s}$ D. Howarth Discourse (Open University Press, Buckingham, 2000), p. 2.

6o Howarth Discourse, p. 4.

67 D. Snow, E. Rochford, S. Worden and R. Benford 'Frame Alighnment Processes, Micromobilization and Movement Participation' American Sociological Review, Vol. 51, No. 4, (1986), pp. 464 - 481, D. Snow, R. Benford 'Master Frames and Cycles of Protest' in A. D. Morris and C. M. Mueller (eds.) Froniters in Social Motement Theory (Yale University Press, New Haven and London, 1992), pp. 138 -155.

68 Shepherd Gender, Violence and Secwrity, p. 17.

69 Zalewski Feminism After Pasimodemism p. 55.
} 
constituted drives the initial problematisation and critique forming this study, which focus on how gender security discourse is made.

Fundamental to poststructural ontology is a concern with language, which should not be equated to specific instances of linguistic expression. Derived from Saussure's understanding of connections between language and social relationships, and that language is form and not substance, poststructuralist scholars emphasise the inherently social and political nature of language. ${ }^{70}$ As described by Lene Hansen, language is

\begin{abstract}
'an inherently unstable system of signs that generate meaning through a simultaneous construction of identity and difference. The productive nature of language implies that policy discourse is seen as relying upon particular constructions of problems and subjectivities, but it is also through discourse that these problems and subjectivities are constructed in the first place'.7"
\end{abstract}

Critically, language has a productive nature, highlighting that language makes meaning. The ontological concern with language is practiced through the epistemological centring of discourse - which is best understood as a system of meaning-making. In this thesis discourse is percieved as a system of meaning-making through which social configurations are rendered meaningful. This perspective accepts that the meaning of "security" has been made through a range of discourses making possible and limiting the social and political world.

Recognising the productive nature of a discourse means that what is constituted as "security" relies upon subjectivities constructed through a posited opposite, usually insecurity. The implication here is that in any discursive formation of "security", there will be "insecurity". Poststructural explorations of how "security" is discursively constituted open up metatheoretical concerns regarding the very nature of in/security and how such notions are constructed through power and identities. For instance, Maria Stern, in her study of Mayan women in Guatemala during the 1990s, highlights how notions of in/security are inscribed through invoking a specific identity of resistance against the prevailing Guatemalan nationalism.72 Similarly, David Campbell's genealogical examination of United States foreign policy unpacks the way in which state identity has been constituted through interpretations of security threats posed by others. ${ }^{73}$ "Security" and "insecurity" can be discursively composed through a series of social-relational practices within a particular space, as illustrated by Paul

\footnotetext{
${ }^{70}$ F. de Saussure Course in General Linguistics (eds.) C. Bally and A. Sechehaye (Foutana/Collins, Glasgow, 1960).

${ }^{7 L}$ L. Hansen Seckrity As Practice, p. 17.

72 M. Stem Naming Security - Conitructing Identity: 'Muyan-pomen' in Gualemula on the ext of Peace' (Manchester University Press, Manchester, 2005).

${ }^{73}$ Campbell Writing Security.
} 
Higate and Marsha Henry in their comparative study on peacekeeping in Haiti, Kosovo and Liberia. ${ }^{74}$ For Laura Shepherd, discourses of security support 'the primacy of the international... through the identification of objective threats, the construction of international order and the perpetuation of the myth of the state. 75 In other words "security" is discursively constructed in such a way as to support particular configurations of power. In this thesis, I aim to appreciate that security - made possible through the 'intuitive consciousness' of insecurity - is a discourse, to highlight inscriptions of power and identity within configurations of "security". 76

\section{Components of Discourse.}

By viewing discourses as systems of meaning-making, it is recognised that there is more than one component part delineating a discursive formation and its effects. That is, meanings are made through a complex relationship between significations, articulations and representations. In this study, multiple and simultaneous significations, articulations, and representations of gender security are flagged up as systems of meaning-making. The deeper theorisation about significations and representations as they relate to articulations is unusual. Generally, poststructuralist approaches are primarily concerned with articulation, which refers to practices connecting the elements forming a discourse. ${ }^{77}$ That is, such works concentrate upon how a meaning is constituted. However, in this thesis, recognising the role of personal-political imaginations in constituting a meaning requires us to flesh out poststructuralist notions about significations and representations. This emphasises that politics is driven by the construction and perception of difference and the possibility for change, and as such, actors posit and view themselves in opposition to another, simultaneously occurring discursive formation. It is therefore necessary to realise bow these differences are constituted and presented, and this is where deeper sensitivity about significations and representations are useful.

Articulations are invoked to 'understand concrete social practices in which social actors articulate discursive elements along the axes of equivalence or difference'. ${ }^{78}$ An articulation is a practice which 'consists in the construction of nodal points which partially fix meaning'. ${ }^{9}$ That is, nodal points

\footnotetext{
74 ligate and Henry Insecure Spaces.

is Shepherd Gender, Violence and Security, p. 74.

76 'Intuitive consciousness' refers to Derrida's critique of binary oppositions as structuring forces in language. See Derrida Of Grammatology, p. 73.

$\pi$ E. Laclau and C. Mouffe Hegemony and Sacialist Strategy: Towands a Radical Demorratic Politics (Verso, London, 2001), p 105.

7 Glynos and Howarth Logics of Critical Explanation, p. 180.

79 Laclau and Mouffe Hegemony and Sacialist Sirategy, p. 113.
} 
dominating the discursive terrian - known as signifers in this study - are constructed. ${ }^{80}$ Articulatory practice refers to the making of connections between signifiers. Once the signifiers and connections between them are partially fixed, a specific discourse has been articulated. The notion of partial fixation is important. Since the elements which are connected are constructed, the possibility of alteration is left open, resulting in a partial fixation. All discourse is made up of 'successive moments' of fixation and non-fixation. ${ }^{81}$ This perspective underscores that discourses are 'incomplete' linguistic systems produced by the 'play of differences' mediating and organising our experiences of the world. ${ }^{82}$ Our understanding of articulations so far suggests that the discourse of "gender security" is articulated through a range of practices that highlight particular signifiers - such as violence or women - as being of critical importance in partially fixing a meaning of "gender security".

The unfixed nature of an articulation results in 'the openness of the social' following 'the constant overflowing of every discourse by the infinitude of the field of discursivity'. ${ }^{83}$ This point stresses the place of social relations where discourse is concerned. In essence, social relations are constituted, meaning that discourses are product and productive of the social context in which they act. This particular logic of articulation is one where contingency inhabits not only the different elements that are linked together to form a discourse, but also the hegemonic project or subjects that strive to fix meanings, as well as social structures themselves'. ${ }^{84}$ As a consequence, 'every social process of putting together elements is to some degree articulatory, and this is because they (and the agents of articulation) are not governed by underlying metaphysical principle or ground'. ${ }^{85}$ By recognising the contingency of the social, the practice of "gender security" is recognised as being affected by the context in which the discourse is constructed, located and produced. Hence, discourses of "gender security" are product/ive of partially fixed signifiers: the perception that our social world is constituted through a temporary clustering of practices remains a constant theme throughout this thesis.

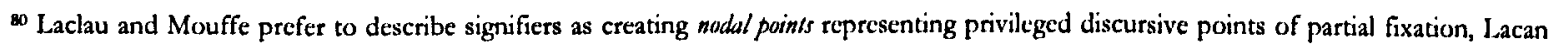
conceives of these partial fixations as points de cuplion, which in Derridain theory accumulate around a Master Significr (sce also Edkins). There are subtle differences within these approaches: but both a Master Signifier and nodal points work to 'produce the particular social order and constitutes subjectivities by concealing the lack around which social order is constituted, the antagonism at its heart'. J. Edkins 'After the Subject of Intemational Security' in A. Finlayson and J. Valentine (eds.) Politics and Pu.rt-Siructurulism: An Intrudkction (I:dinburgh University Press, Edinburgh, 2002). I prefer to use signifiers, for the sake of theorctical simplicity and coherence.

11 Laclau and Mouffe Hegemony and Socialist Strategy, p. 110.

${ }^{82}$ Derrida Of Grammatology, pp. $3-93$.

${ }^{83}$ Laclau and Mouffe Hegemony and Sorialint Sirutegy, p. 113.

${ }^{84}$ Glynos and Howarth Logics of Critical Explanation, p. 179.

ss Ibid. 
The articulatory practices forming discourses of "gender security" are signified and represented as a complete discourse. Signifiers are elements embedded within a wider discursive field: where these signifiers are connected, a discursive totality is articulated. The term signification is used in this study to describe how social actors "make" meanings of particular discourses through connections of signifiers. The notion that language is made up of signs, signifiers and the signified was initially advanced by Saussure. ${ }^{86}$ Saussure recognised that language was made up of meanings: his structuralist account insists upon a language made up of fixed and arbitrary meanings that are shaped because something is not something else. ${ }^{87}$ For example, we recognise that a tree is not a flower, and therefore it is a tree. The construction of these binaries came under fire from Derrida, who criticised Saussure's insistence on an autopoietic linguistic system. Derrida pointed out that language relies upon differance, where meaning is made through difference and deference. ${ }^{88}$ Derrida argued that signifiers maintain an external set of meanings. ${ }^{89}$ In sum, the notion of signification describes how we fix particular meanings onto a sign, or explains how contexts shape the changing sign, signifiers and the signified.

A poststructural conceptualisation of signification stresses the locat[ion] in a discursive context and the temporary fixing of meaning in a specific reading of signifiers depend[ing] upon the discursive context'.90 For example, Chris Weedon points out that the 'meaning of the signifier 'women' varies from ideal to victim to object of sexual desire, according to its context'.91 The meaning that a signifier has is given by the signifier's location within the wider discourse, constituted by relationships to other signifiers: signs, signifiers and significations are always context-specific. The clustering of signifiers crafts a signification, which is then 'temporarily halted' enabling 'meaning [to be] installed'. 92 This study does not seek to identify the signifiers that constitute a meaning of "gender security": rather, as will be clear in chapter four, actors are asked what gender security means. Through this, the claimed and declared signifiers are identified, highlighting the meanings that agents give to a discourse. This approach is inherently poststructuralist, revealing a concern with one type of meaning-making: how agents understand themselves to be making meanings and connections. It is not - and does not intend to be - a full and complete "truth": rather, it is a means of understanding how activists have constructed a set of politics positing themselves in opposition to other visions of "security". By

\footnotetext{
so de Saussure Course in Generul Linguistics.

a7 Ibid., p. 67.

Derrida On Grummatology, pp. $6-73$, especially pp. $62-3$.

9 Ibid., p. 14.

Th Weedon Feminist Practice and Passtinucturalist Theory, p. 25.

" Jbid.

n2 Edkins 'After the Subject of International Security', p.72.
} 
identifying the claimed and declared signifiers, the limitations and possibilities that particular imaginations and visions of "gender security" has for political action is revealed.

Questions remain about how a discourse is represented as knowledge. I adapt the terminology of representations to describe the means by which a discursive practice is presented, usually to achieve political presence, effect and/or practice. In doing so, the study follows Laura Shepherd's twofold conceptualisation of representation: 'representation as an instance and representation as a practice'..$^{93}$

The first, representation as an instance of discursive practice, refers to ways that texts produce a specific and particular representation of a situation. ${ }^{94}$ Texts are broadly conceived and not limited to written, visual, or linguistic examples of a discourse manifesting itself. These texts are connected: either by directly referring to another text, or within social (sub)consciousnesses which construct meaning. Both are notions known as intertextuality. Texts represent particular images which not only represent a discourse, but are also productive of the discourse. Textualising a domain of analysis recognises 'that any "reality" is mediated by a mode of representation' and that 'representations are not descriptions of a world of facticity, but are ways of making facticity'. ${ }^{55}$ In other words, any presumed reality that is represented depends upon a range of constructed knowledges. The ways in which particular discourses are represented can have powerful impacts within international politics. For example, Robin Redhead's investigation into the visual representation of Amnesty International's 2004 campaign 'Stop Violence Against Women' reveals ways sex and gender are conflated, perpetuating articulations of women-as-victims-not-agents in human rights discourse. ${ }^{96} \mathrm{~A}$ representative instance designed to portray a specific situation can (re)produce particular articulations and/or significations, affecting wider discourse and discursive effects.

The productive nature of representation is noted in the second conceptualisation of representation: representation as practice. This perception of a representation recognises contingency in the very act and practice of representation. Stuart Hall suggests that a representation 'means using language to say

\footnotetext{
${ }^{93}$ Shepherd Gender Vialence and Security, p. 24.

94 Ibid.

${ }^{95}$ M. J. Shaprio 'Textualising Global Politics' in J. Der Derian and M. J. Shapiro (eds.) Intertextual/Intemational Relations: Postmodem Readings of World Politics (Jexington Books, New York, 1989), pp. 13-4.

26 R. Redhead 'Visual Representation in Amnesty International's 2004 Campaign 'Stop Violence Against Women" Internationul Feminist Jokmal of Politics, Vol. 9, No. 2. (2007), pp. $218-2.38$.
} 
something meaningful about, or to represent, the world meaningfully to other people'. ${ }^{97}$ While this conceptualisation recognises the connection between language and meaning, the role played by the contexts influencing a specific representation is somewhat downplayed. Recognising the contingency of meaning, my understanding of representations follow Judith Butler's, where representations 'are never merely descriptive, but always normative, and, as such, exclusionary..98 Michael Shapiro also emphasises contingency, recognising that 'the real, or the what of our knowing, is inseparable from how it resides in our modes of representation'.99 That is, what we present as "real knowledge" is essentially represented: what is (re)presented as knowledge about "gender security" depends upon the selection of articulated discourses. Critical to this thesis is the notion that a representation of "gender security" is the political posture and presence of articulated and/or signified meanings related to gender security, but also that these representations are productive of meanings about gender security.

The practices and processes of significations, articulations and representations constitute a discourse acting as a social structure which is inherently ambiguous, incomplete and [reliant upon] contingent systems of meaning' ${ }^{100}$ The realisation of contingency and ambiguity in the construction of a discourse is innately poststructural. Ambiguity results from the arrangement of elements constituting an articulation. The component parts of a discourse are relational - that is, they operate together and refer to other discourses and parts of discourses (signifiers). Together, they form a logic and 'reference criteria', necessary for understanding and evaluating discursive forms. ${ }^{101}$ The aim is to describe the set of relationships that make up a particular political and social perspective that is represented, 'not to measure the relative importance of ideas and materiality but to understand them [ideas] as constructed through a discourse which gives materiality meaning by drawing upon a particular set of identity constructions'.102 That is, the concern in this thesis is how personal-political imaginations of activists shape specific configurations of gender security:

97 S. Hall 'The Work of Representation' S.Hall (ed.) Repnesentution: Cullural Representations and Signifying Prattices (Sage, London, 2003 ), p. 15.

98 $\mathrm{J}$. Butler, cited in Shepherd Gender, Violene and Security, p. 24.

9 M. J. Shapiro The Politics of Representation: Writing Practices in Biography, Pholograpty, and Poligy Anatysis (The University of Wisconsin Press, Wisconsin, 1988), p.8.

${ }^{\text {too }}$ Howarth Discourse, p. 4

101 Ibid., p. 114.

102 Hansen Security As Practice, p. 23 


\section{Analysing Discourse}

Having outlined how discourse is conceived, attention now focuses upon describing how discursive practices and terrains have been explored. The ontological and epistemological commitment to understanding discourse as an inherently unstable, ambiguous and constituted system of meaningmaking, shaping social and political power and identities, suggests that discourse analysis is necessary. Discourse analysis seeks to examine the 'historical and political construction and functioning' of

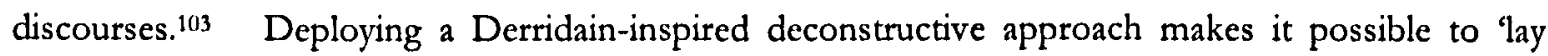
bare... ambiguities and exclusions, thus weakening any essentialising projections into the concept and/or exploring repressed possibilities foreclosed by reductionist proclivities'.104 Derrida evaded laying out a specific "method" of deconstruction, to avoid restraining the identity of "deconstruction" through giving it a label.105 It is more useful to view deconstruction as a mode of textual interpretation. Deconstruction seeks to question how a meaning is made, by 'rejecting unitary intentional subjectivity, locating meaning in texts and their relation with other texts, insisting that this meaning is not only plural but constantly deferred in the never-ending webs of textuality in which all texts are located'.106 That is, deconstruction emphasises a contextualisation and decontextualisation of texts and their relations to other texts for critique.

Through a concern with 'both the constitution and deconstitution of any totality,' deconstructing notions of "gender security" (as a represented discursive totality) aims to unsettle apparently fixed meanings. ${ }^{107}$ This destabilisation illuminates how signifiers work to (re)produce, (re)legitimise and (re)present the discourse of gender security. Deconstructing the text of personal-political imaginations of activists in Serbia revels how "gender security" is conceptualised, and how these conceptualisations are shaped. As explored in chapter three, these conceptualisations are significantly shaped by how war, conflict and post-conflict ambitions are imprinted upon the personal-political imaginations of activists. Therefore, the target for deconstruction is upon how logics about war, conflict or post-conflict feature in the context of gender security discourse. In doing this, a deconstructive method reveals the very different articulations and representations of "gender security" by actors, highlighting the social and political processes that shape competing and/or

\footnotetext{
${ }^{103}$ J Howarth Diccourse, p. 5.

${ }^{114}$ Glynos and I Iowarth Logics of Critical Explanation, p. 181.

105 J. Wolfrcys Deconstructione Demida (Macmillian, Basingstoke, 1998), pp. 6 - 7.

100 Weedon Feminist Practice and Paststructurulist Theon, p. 159. It is worth stressing the poststructuralism has a broad conceptualisation of 'text'.

${ }^{107}$ Quotation rctrieved from R. Dcvetak 'Postmodemism' S. Burchill et. al. (cds.) Theories of Intemational Relations (Palgrave, Basingstoke, 1996), p. 187
} 
alternative logics of gender security. Deconstructive thought emphasises the constitutive nature of discourses, stressing that discourses are internally constructed in relation to other discourses.

While concerns about "gender security" have been heightened by the presence of UNSCR 1325 - the Security Council resolution passed in October 2000 on Women, Peace, and Security - analysis does not concentrate upon UNSCR 1325 per se. Rather, analysis aims to deconstruct the wider discursive context of "gender security" in which UNSCR 1325 is embedded. Concentrating upon the construction of a discourse is an approach that recognises the complexity of international politics, which James Der Derian insists requires an,

'intertextual approach, in the sense of a critical inquiry into an area of thought where there is no final arbiter of truth, where meaning is derived from an interrelationship of texts, and power is implicated by the problem of language and other signifying practices.' ${ }^{108}$

Analysing discourses enables us to recognise connections and contingency in international politics, and specifically, the constructed nature of discourses that drives political action. Since discourses are constructed - including discourses of gender security - discourse analysis reveals that different ideas, ambitions and operational frameworks can be attached to the same discourses. Examining the personal-political imagination of activists (specifically deconstructing how activists perceive war, conflict and post-war reconstruction) reveals bow, and wby, gender security is configured in various ways.

\section{ANALYTICAL STRAGETY (2): NARRATIVES AND TEMPORALITY}

Deconstructive thought queries the notion of a coherent historical narrative by highlighting the impossibility of real beginnings and criticising teleological explanations for the development of ideas. In essence, deconstruction emphasises how the political and politicised nature of narratives serves to reinforce hegemonic explanations. A concern with narrative forms an important element of the analytical strategy deployed in this thesis. Specific attention is paid to how personal imaginations of the pasts, presents and futures of conflict and post-conflict reconstruction become political, affecting the very constitution of "gender security". This inherently poststructuralist curiosity urges for "radical rethinkings of questions [about] the political functions of knowledge, memory, [and] history'.109 In this thesis, by seeking to make sense of how "gender security" has been configured, the political functions of various temporal moments are emphasised. This renders apparent impacts that recalled

1ns J. Der Derian 'The Boundaries of Knowledge and Power in International Relations' J. Der Derian and M. J. Shapiro Intermational/Intertextual Relations; Posimodem Readings of World Politics (Lexington Books, New York, 1989), p. 6.

${ }^{109}$ R. Ashley 'The Achievements of Post-Structuralism' in Intermational Theogy: Positivism and Beyond S. Smith, K. Booth and M. Zalewski (cds.) (Cambridge University Press, Cambridge, 1996), p. 245. 
memories, perceptions about the contemporary context, and hope for future change has upon political practice. In this section, I will initially explore how time and temporality is conceptualised, stressing the undecidability of time and narrative. Attention will then turn to the connections between narrative and personal-political identities, highlighting how explanations we construct shape our personal-political imaginations. Finally, various temporal moments are illuminated, setting the scene for analysis of how pasts, presents and futures construct our personal-political imaginations of gender security.

\section{Thinking about Time and Temporality in IR}

Time can be thought about in several ways in the study of IR. Time can be viewed in a fixed, structuralist way. For instance, Valerie Bryson argues that quantitative time-use studies can be a 'potentially feminist tool' to demonstrate inequalities, highlighting 'male privilege and female disadvantage'.110 For Byrson, time is a measurable and unchanging construct that becomes a 'tool' to achieve specific goals: the politicised use of time is the very point. Time also has political purposes for critical theorists, who aim to 'provide guidance about 'what is to be done'... if a different future for international politics is to be envisaged'."11 In contrast, the perception that time, temporality and narratives are constructed reveals how representations of time has political effects. Lee Jarvis highlights how different notions of time are inscribed into narratives about September 11, 2001.112 By isolating the implicit and explicit articulations of time and temporality across texts produced by the Bush administration, Jarvis produces an account delineating ways that time functions to inscribe moral and political legitimacy for the actions of the Bush administration. ${ }^{113}$ My own conceptualisation of "time" is close to the poststructural understanding put forward by Jarvis, emphasising the political contingency of narratives. That is, personal-political imaginations about the past, present and futures of conflict and post-conflict imaginations have served to inscribe particular configurations of gender security.

However, in using time as an analytical strategy, I seek to emphasise several temporal moments: that is, the past, the present, and the future. This attempts to address one of the key issues with contemporary IR theory, which, as pointed out by John Hobson, is trapped between chronofetishism

\footnotetext{
110 V. Bryson 'Time-Use Studies: A Potentially Feminist Tool' Intemational Feminist Jowmal of Politics, Vol. 10, No. 2 (2008), pp. 135 - 153.

'I' K. Hutchings 'I lappy Anniversary! Time and critique in International Relations theory' Review of Intemational Studies, Vol. 3.3 (Special Issue, 2007), p.78.

${ }^{12}$ L. Jarvis Times of Termor. Discourse, Temporulity and the Wrar on Termor (Palgrave, Basingstoke, 2009).

113 lbid.
} 
and tempocentrism.114 Chronofetishism refers to a mode of analysis where 'the present' is 'seal[ed] off so an analysis 'appears as an autonomous, natural, spontaneous and immutable entity'.115 That is, the past - or the present - is not evaluated in relation to the critique being made. Hobson also highlights how IR is hindered by tempocentrism, which encourages transhistorical study that does not pay attention to context, making all historical moments take on similar characteristics. ${ }^{116}$ Hobson urges IR scholars to 'bring history back in' to understand the present better.117 While I agree that "the past", is important to "the present", I also want to bring in notions about "the future" into analysis. This is especially important to analysis of security discourse, as pointed out by Betty Reardon, 'security is in large part futures perception', given that "security" lies in 'things hoped for and planned for'.118 Past, present and future are all modes of time that feature in the personalpolitical imaginations of individuals, operating together to function as a narrative that explains political practice.

Drawing upon a Foucauldian concern with 'the archaeology of knowledge', this study recognises the role of multiple and contingent temporalities in narratives that support a discourse. ${ }^{119}$ Foucault queries the notion that discourse is 'already articulated in that semi-silence that precedes it', continuing to 'run obstinately beneath it, but which it covers and silences'. ${ }^{20}$ In essence, political ideas do not emerge from a singular narrative. These singular narratives frequent 'norm-evolution' explanations dominating constructivist modes of thought. Constructivist projects are problematic because they 'do not address the structures of our thought and therefore end up reinforcing, rather than challenging, 'common-sense' ways of thinking'. ${ }^{21}$ This is because constructivist narratives have a starting point, "claim[ing] possession of an origin... this is suspect as it closes down fields of signification'.122 Laura Shepherd takes issue with how 'constructivist orthodoxies' explain the production of policy documents and resolutions (like UNSCR 1325) are explained as being 'produced

114 J. M. Hobson 'What's at stake in 'bringing historical sociology back into intemational relations'? Transcending 'chronofetishism' and 'tempocentrism' in international relations' S. Hobden and J. M. Hobson (eds.) Historical Sociology of Intermational Relations (Cambridge University Press, Cambridge, 2002), pp. 5. Kimberly Hutchings has written on the place of pasts and futures in accounts of present international political time. See 'Happy Anniversaryl' and Time and W'orld Politics: Thinking the Present (Manchester University Press, Manchester, 2008).

119 Hobson 'What's at stake', p. 9.

116 lbid.

11 Ibid., pp. 3 - 5 .

118 B. Reardon Women and Peace: Feminist Visions of Global Securiy (State University of New York Press, Albany, 1993), p. 22.

${ }^{119}$ M. Foucault The Archaeology of Knowledge (Routledge, London, 2008).

120) Jbid, p. 28.

121 M. Zehfuss Constructivism in International Relution.: The Politics of Reativy (Cambridge, Cambridge University Press, 2002), p. 246

122 lbid. 
over time', thus ignoring how 'institutions are sites of discursive power and both product/productive of particular discourses that in turn constitute particular horizons of possibility'.123 Constructivist norm-evolution narratives are problematic in that they craft a presumed commonsensical explanation that downplays the impact of power in the construction of an account. Rather, I wish to highlight that narratives are representations of (inter)subjective temporalities. In other words, the analysis of "gender security" in this thesis begins from the premise that perceptions of different and/or multiple temporal moments serve to intertwine and reinforce each other, to craft a sense of "gender security".

This notion of time and temporality as a politically contingent discursive device arises from two interlinked notions. The first is that the beginning and the end is undecidable. This perception, derived from Derrian deconstructive method, highlights that all apparent beginnings and endings are inscribed within a context. The second notion is that there is 'no universal story, no 'metanarrative' capable of linking our pasts, presents and futures into the coherent totalities for which we may intuitively search'.124 In other words, different temporal moments cannot be definitely shaped into a narrative with any certainty: the way in which a narrative is arranged has political consequences. Time which is arranged in a linear way is assumed to be 'an empty, homogeneous medium in which events take place': it is not. ${ }^{125}$ This is because in our temporal, personal-political imaginations, forgetting and memory 'reinstall' time as a linear entity, narrating events as history. ${ }^{126}$ In this thesis, I argue that narratives are politicised, and have political consequences, as the very representations of the "past" conflict, the "present" problem which is recalled operate to define and constitute the post-conflict "future" hopes for securing gender security.

\section{Temporality and Identity}

Narratives are politicised because they are closely entwined with identities: how a narrative is constructed is both product and productive of our selves. Kimberly Hutchings suggests that 'feminist critics point to what is missing in predominant temporal framings of world politics, but they also suggest alternative ways for thinking about world-political time that might offer a different way forward for understanding 'our' times'.127 That is, in explaining the problems with the past and

\footnotetext{
${ }^{123} \mathrm{~L}$. J. Shepherd 'Powet and Authority in the Production of United Nations Security Council Resolution 1325' Intemutional Studies Quartery (2008), Vol. 52, No. 2, p. $384-5$.

124 Jarvis, Times of Termor, p.6.

${ }^{125}$ J. Edkins Trauma and the Memory of Politics (Cambridge University Press, Cambridge, 2003), p. xv

126 Jbid., p. 15.

${ }^{127}$ Hutchings Time and World Politics, pp. $160-7$.
} 
present, (some) feminists seek to put forward ambitions for the future. These narratives are the feature of the political identity that feminists ascribe to themselves - and this is particularly the case for activists. Woven through the personal-political imaginations that shape activist ambition is a sense of 'what is to be done' in the future, based upon how activists problematise the past and present. These senses of temporality are infused in the political position that is articulated and represented: it forms the basis of the political self of activists. These narratives are not just political: they are personal too. Activists utilise their (recalled) experiences within narratives: these experiences are represented as the foundation of their knowledge. Thus, how a narrative is arranged and explained shapes the personal-political identity that activists claim.

In this study, these identities are wrapped up with specific narratives about conflict, war and violence in Serbia, and the future direction of post-war reconstruction. For instance, activists draw upon personal experiences of war and conflict to explain political positions about future post-war reconstruction strategies. Conversely, some activists refused connections between their experiences of war and conflict and the present or future: war and conflict are part of a past that has little bearing on the present or future. As will be explored in chapter three, the way that various temporalities of war and conflict are represented form part of the personal-political identity put forward by activists in relation to how "gender" and "feminism" is conceptualised. These positions on gender and feminism shape interpretations and practices of gender security. These gender identities are simultaneously personal/individual and political/collective. Understanding ways that individual and collective identities merge to craft a specific political identity about gender was critical to the analysis of this thesis. Generally, interviews took place with individuals discussing perspectives about collective positions (in other words, an NGO). Narratives relating political gender identities with temporal positions about war and conflict were simultaneously individual and collective identities. In other words, how various temporalities about war and conflict are framed and represented is bound up with personal-political identities.

Understanding time in this way required innovative analytical strategies to explore the effects upon gender security. I took as a starting point Daniel Conway's reminder that,

'Any account of the past offered by an individual should be consciously interpreted from within the context of the present and historical accounts offered by individuals should be interpreted as versions of reality rather than an infallible account of events'. ${ }^{128}$

120 D. Conway 'Masculinities and Narrating the Past. Expericnces of Researching White Men who Refused to Serve in the Apartheid Army' Qualitative Research, Vol. 8, (2008), p. 353. 
To Conway's reminder, it is necessary to incorporate awareness of how future hopes linger in the narratives of our histories and our perceptions of the present. As such, I sought to make sense of discourses through recognising the presence of multiple temporalities. To provoke responses incorporating some sense of temporality, I utilised a tactic similar to that used by Inger Skjelsbák in her study of how perceptions of 'good womanhood' in Bosnia has changed as a result of war.129 Skjelsbǽk asks participants questions about what 'good womenhood' meant during specific blocks and periods of time, using words like pre-war, wartime, postwar to prompt a narrative about a particular "era".130 Analysing how notions of temporality are infused into personal-political imaginations requires reflection upon how the past, present and future has been authored within activist narratives, narratives that were often provoked by my questions.

Narratives incorporating senses of various temporalities were delineated by activities because the temporal arrangements of these narratives were constitutive of their personal-political imaginations. In interviews, I made it clear that I was interested in memories and perceptions of war and nationalism during the 1990s. I also asked questions about their perceptions of contemporary problems and future hopes. These questions provoked responses on a range of temporal moments: indicative of activist personal-political imaginations which problematised conflict and post-conflict eras. Because a view about conflict was requested, these narratives about conflict and post-conflict become a feature of the identities that activities in Serbia ascribe to themselves - even in the refusal or the silencing of a connection between their activism and problematisation of their post-conflict present. These perspectives about conflict and post-conflict intersected with claimed positions in relation to "gender", providing insights into how and why "gender security" is conceptualised in various ways. The discussion of various temporal moments relating to conflict and post-conflict in Serbia are recognised as constructions of personal-political identities claimed by activists, which shape how gender security is conceptualised.

\section{Temporal Moments}

I refer to multiple or various temporalities to recognise interconnections between past, present and futures. Generally, "the past" is a 'whole body of events that has occurred'.131 The notion that the

\footnotetext{
129 I. Skjelsbák 'Traditions and Transitions: Perceptions of 'Good Womanhood' Among Twenty Bosnian Focus Group Participants' Intemational Feminist Joumal of Politic, Vol. 11, No. 3, (2009), pp. 392 - 411. It should be stressed that I carried out individual or small-group interviews, rather than the focus-group that Skjelsbák used.

${ }^{130}$ Ibid.

${ }^{131}$ K. Jenkins Re-thinking History (Routledge, London, 1991), p.6
} 
past is something that has already happened is not problematic: difficulties lie in trying to grab hold of, and understand "the past". In this study, two main facets of "the past" are emphasised. The first piece of the past is an understanding based upon textual, archival documents from the past. Another portion of the past highlighted is the perception about the past within interviews and memories. In Serbia, these narratives about the past are closely related to memories of conflict. Literature about post-conflict memories of conflict has focussed upon political responsibility for the Holocaust in modern Germany, commemorative practices, or the selection of exhibits in a war museum. ${ }^{132}$ These studies explore how states, statehood and nationalism are configured within a national memory of trauma and conflict. This thesis differs as the focus is on how memories and perceptions about the past conflicts shape contemporary gender security discourse. That is, the gender politics of activists is connected to their views about the Serbia's role in a post-conflict past and how the past should be represented in the present. Discourses about and from the past are significant to the analysis in this study, supporting insights about how NGOs in Serbia have interpreted gender security.

Examining documents from the past is often thought to be a voice from the past; a firsthand account of events. ${ }^{133}$ Not quite. All documents go through several stages of selection(s) by an unidentified number of people; from the stage where someone's voice is selected for preservation to the stage where the author is able to find the source, reads it and judges it to be relevant. Documents utilised in this study include a number of "Women for Peace" texts published between 1993 and 2008, used for deconstructing the discursive logics of Women in Black in chapter five. In addition, in chapter six, articles published during the 1980s and 1990s describing contemporary Serbian feminism were treated as documents from "the past" in order to understand the discursive logics of debates against domestic violence. These documents are useful as a 'reconstruction of part of [a] life', helping 'obtain an historical understanding of a person, group, or institution'. ${ }^{134}$ Evaluating documents from the past are not used as a "firsthand account of events", but rather, to enable assessment of the impacts of long-held discursive logics upon feminist conceptualisations of gender security and how UNSCR 1325 is interpreted.

Written documents are limited in that they can only tell us about stated and claimed past values, and not about the discursive interactions between past and present. Interviews are particular textual form

132 On historical responsibility in Modem Germany, see J. K. Olick The Politits of Regret: On Collectire Memory and Historical Responsibility (Routledge, London, 2007) on commemorations of political trauma, see Edkins Trauma and the Memory of Politics, on war museums see C. Enloe The Curious Feminist: Seartbing for Women in a New Age of Empire (University of California Press, Berkeley, 2004), pp. 195 - 204.

133 R. G. Burgess 'Personal Documents, Oral Sources and Life Histories' in R. G. Burgess Field Reseunh: a Soumebonk and Field Manual (Unwin Hyman, London, 1982), p. 201.

134 Jbid. 
which is a 'text that is constituted through interaction and dialogue rather than monologue', acknowledging the discourse analyst has a role in the production of this text. ${ }^{135}$ The timing and context of interviews plays an important part in shaping how the past is recalled, viewed and framed: that is, the present mediates the past. Simultaneously, the past shapes the present, as the interviewees explain how their knowledge and experiences influences their contemporary actions. For example, a study comparing two interviews of a Vietnam War veteran, one conducted in 1968 and the second in 2002 , about the same event reveals different narrative strategies. ${ }^{136}$ In the later interview, the veteran 'has bound up his account into an understandable story' which 'paints a clearer and broader picture' that replaces the 'finely detailed' but confused account that was recorded in 1968. ${ }^{137}$ The differences between the two interviews indicate that the passing of time enables a reconfigured narrative to be given, demonstrating the importance of context in shaping how the past is recalled. The individualised and subjective nature of memories recalled during interviews can be revealing in providing an insight into how attitudes are formed, and how individuals organise their thoughts.

Memories - and forgetting - shape the articulations and representations of gender security. Memory 'is in effect constructed not only in the moment of remembering, but also in the telling of the memory... so memory can be seen as part of the present and the past, as well as shaped by expectations for the future'.138 That is, a (selected) memory reverberates through other temporal moments, affecting the articulation and representation of a discourse in a present or future moment. For instance, memories of communism in central and south-eastern Europe continue to affect gender politics. Communism is (often) remembered as a "good time" for gender equality, ensuring that designing gender policies in the region is a complex matter. ${ }^{139}$ While memories are an aspect of the past which is recalled, we should not forget about forgetting. As Jenny Edkins points out, limitless memory would not be memory, but rather, 'infinite self-presence'. ${ }^{140}$ The act of forgetting and/or silencing serves as a reminder of the 'radically political' nature of 'crafting memories (and futurespasts)'. ${ }^{141}$ The construction, recalling, reproduction, representation and articulation of memory and

\footnotetext{
${ }^{135}$ Chouliaraki, cited in Hansen Security as Pructice, p. 86.

136 F. H. Ailison, 'Remembering a Vietnam War Firefight: Changing Perspectives over 'Time' in Oral llistory Review, Vol. 31, No, 2 (2004),

137 Ibid., pp. $75-76$.

138 Stern 'Racism, sexism, classism', p. 184.

${ }^{139}$ M. Blagojevic Knowledye Production at the Semiperiphery: A Gender Peripective (SZR "Zuhra Simic", Bcigrade, 2009), pp. 53 - 4. The memory of Communism as a "good time" is pervasive and was often invoked during interviews. See Chapter four for further analysis.
}

${ }^{140}$ Derrida, cited in Howarth On Discourse, p. 37.

${ }^{141}$ M. Zalewski et. al. 'The Art of Crafting the Future-Present-Past' Intermational Feminist Jourmal of Politics, Vol.11, No. 3 (2009), p. 320. 
memories is a political act that forms part of a narrative used to support a specific configuration of a discourse, such as the discourse of gender security.

The "past" has a complex relationship with the "present". Indeed, 'the 'past' is...never really 'past' but continuously constitutive of the 'present'... The present, is other words, is what the past - as received and creatively interpreted by the present - has made it'. ${ }^{142}$ In essence, the present is influenced by particular and specific interpretations, recall, and reconstructions of the past. In interviews, even where questions specifically asked about a memory, it was clear that perspectives of past events or actions were mediated and remembered through the present, tangling the timeframes involved. Certainly, texts are 'performed through the central discourse of their present, thereby lifting parts with representational similarity out of older texts while ignoring or silencing others'. ${ }^{143}$ On surface, this suggests that the interviewer and interviewee select discourses from the pasts to support present actions and representations, but it is more complex than this: the discursive present is shaped by the discursive past. NGOs have a specific political agenda usually relating to what the individuals in the organisation see as a contemporary problem or issue in society that activists believe needs to be addressed. As such, in a narrative, these problems are located in the present, and given a beginning at some point in a past, but the solution forms part of the future.

Aspirations for the future are critical to political agendas, and yet "the future" remains a curiously under-researched temporal element in politics and international relations. Whether implicit or explicit, all IR theories make assumptions about the future, guided by the extent to which change is possible. For instance, realist and neorealist approaches emphasise the historical inevitability of insecurity, suggesting that the future reflects the patterns of the past, while Marxist and Critical Theory approaches 'contain an element of utopianism in the sense that it can represent a coherent picture of an alternative order'. ${ }^{144}$ If we accept that political ideas normally contain an assumption about the future and the possibility of change, then social movements, which collate around a set of ideational factors will also contain notions about the future. These notions may be about the configuration of an alternative order, or a wish to work towards eliminating and/or changing something in/about society, or the impossibility of escaping contemporary problems: all elements that contribute to the broader picture of gender politics. For the feminist and women's NGOs explored in this thesis, it is clear that hopes for the future political direction of Serbia deeply affects

\footnotetext{
142 Bryant, cited in Hobsion What's at stake', p. 13.

${ }^{143}$ Hansen Security As Practice p. 58.

144 R. W. Cox 'Social Forces, States and World Orders: Beyond International Relations Theory' Millennium: Joumal of Intermational Studies, Vol. 10, No. 2, p. 132.
} 
the gender politics shaping notions about gender security. Making explicit notions about "the future" in terms of how gender activists envisage securing peace and equality in a post-conflict Serbia reveals something about how and why "gender security" is configured in different ways.

Time, temporality, and narrative are inherently complex entities to deconstruct. By emphasising the politicised nature of a narrative, the contingency of time, and the constant interaction between multiple temporal moments, it is possible to identify ways in which multiple temporalities operate to shape personal-political imaginations of conflict, present post-conflict problems and post-conflict reconstruction. Acknowledging that pasts, presents and futures do not form a linear narrative enables us to think seriously about how multiple temporalities within a discourse are muddled up in a productive interaction resulting in tangible articulations, representations and practices of "gender security".

\section{CONCLUSIONS}

To make sense of some of the ways that discourses of gender security are configured by personalpolitical imaginations, this study utilises a range of feminist-poststructural strategies to understand how discourses of gender security have been signified, articulated and represented. The personalpolitical imaginations of activists are understood through a text formed by multi-sited qualitative and ethnographical data collection methods. These windows of insights and understandings form the context from which judgements are made. Judgements are made about the narratives embodying pasts, presents and futures of conflict and post-conflict presented by activists: these multiple temporalities converge and interact to shape a personal-political imagination that is product and productive of gender security discourse. Any future hopes embedded in the notion of gender security arises from how the past and present is problematised. Gender security is inscribed through, and by, personal-political imaginations of activists because the concept of gender security rests upon normative ambitions. Recognising gender security as normative emphasises the political contingency of various interpretations and practices of "gender security".

Gender and security are both recognised as separate unfixed discourses which are fused together to describe a specific configuration of "gender security". Personal-political imaginations play a key role in momentarily fixing a discourse of gender, security, and subsequently; gender security. This is because the subjectivities of personal-political imaginations constrain and make possible how "gender security" is conceptualised. The notion of "gender security" represented is the political posture and 
presence of articulated and signified meanings related to gender and security - meanings which are inscribed through personal-political imaginations. In this thesis, the personal-political imaginations are viewed as knowledge that forms the subject to be constructed and deconstructed. The deconstructive method emphasises the political contingency of a narrative, critical to how we understand security discourse. Recognising the articulated temporality within a discourse highlights that the "subject" [needing security] is invoked in a temporal narrative with a clear beginning and origin (the past), middle (now), and the promise of a happy ending (security realised in the future)'.145 As such, the analytical strategies articulated provide a context from which gender and security are realised as contingent and constructed, (re)producing a specific configuration of gender security with a particular impact upon a practice.

Understanding discourses as (re)signified, (re)articulated and (re)presented promotes a concern about how language has social and political effects. Deconstruction of various temporal moments relating to war, conflict and post-conflict emphasises the political functions of those moments, and how the imprints of those temporal moments are governed by personal-political imaginations of activists. The narrative of activists - a narrative gathered from a range of multi-sited qualitative and ethnographical insights - provides a particular history, a particular future and perceives a particular present. This narrative is forged out of personal-political imaginations of activists seeking to interpret and practice gender security. These narratives are product and productive of a specific conceptualisation of gender security that is put forward. Ultimately, the logic of gender security discourse is, in part, regulated by particular and specific visualisations of gender and security that condition and limit particular significations, articulations and representations of gender security. The following chapters demonstrate the wide range of security discourse and gender politics that exist, supporting analysis of competing modes of thought about gender security.

145 M. Stem 'Racism, sexism, classism', p. 180. 


\section{CHAPTER TWO.}

\section{APPROACHING SECURITY.}

"Security" is a slippery concept that remains essentially contested within International Relations. The core element, that security means 'the absence of threats' is not in any doubt. Rather, it is the layers of politics 'wrapped around' security and insecurity.' The starting point of security studies scholarship is nearly always insecurity and threats to security; but, what constitutes in/security, or how a threat is constructed, remains contested and dependent upon ontological values. This does not mean that security can take on any meaning one likes: like all discourses, the discourse of security has 'neither absolute fixity nor absolute non-fixity'.2 That is, security discourse is connected in some way to a discursive web that exists around the concept, but simultaneously, the discourse is in a constant state of flux, and can be reconceptualised. However, as Lene Hansen reminds us, 'for problems or facts to become questions of security, they need to therefore to be successfully constructed as such within the political discourse'. ${ }^{3}$ The construction of threats is a consequence of diverse ontological and epistemological perspectives, mainly differentiated by the referent object of security. How we define security impacts upon who is or what is to be secured, and subsequently, bow to achieve a sense of security. Understanding security as a discourse recognises how and why "security" is constructed, shaping the political practice of security.

Debates considering meanings of "security" have been characterised by 'an increasingly detailed set of subdivisions and distinctions', resulting in 'a tendency in Security Studies to move into camps, zoom in on differences rather than commonalities, and to insulate one's own approach from the debates and literatures of others'. ${ }^{4}$ Certainly, there are multiple ways of structuring understandings within the field of Security Studies, ultimately outlining the rationalities that underpin the (academic) discourse of security. ${ }^{5}$ However, these 'subdivisions and distinctions' can have very different impacts: the contrasting visions of gender security discussed later in this thesis exposes different gender effects. To make sense of these subtle differences, in common with much poststructural work in Security

\footnotetext{
1 K. Booth Theory of World Security (Cambridge University Press, Cambridge, 2007), p. 100.

2 E. Laclau and C. Mouffe Hegemony and Sacialist Strategy. Towards a Radical Demukutic Politics (Verso, London, 2001 ). p. 111.

${ }^{3}$ L. Hansen, Security As Practice: Discourse Anatysis and the Basnian War (Routledgc, Abingdon, 2006), p. 34.

4. Hansen 'From Camps to Conversations in Critical Security Studies' Intemational Sindier Review, Vol. 10, No. 3 (2008), p. 652.
}

5ee A. Wibben 'Hluman Security: Toward an Opening' Security Dialogue Vol. 39, No. 4 (2008) pp. 456 - 457 for further refcrences and an outline of some of the debates that affect the structuring of rationalities within academic security studies. 
Studies, the following overview traces the ontological variations in how security has been conceptualised. This avoids a teleological narrative of the field of Security Studies. As a consequence, in this chapter, various academic accounts of security are organised through an intersection between (1) ontological perspectives about structures and (2) the referent subject of security. This intersection demonstrates ways that "security" is discursively ordered. This is more reflective of the debates that have shaped, expanded and limited the field of security studies. While certain ideas have dominated at certain times or within certain contexts, it is the ontological standpoint alongside an understanding of the referent subject to be secured that combine to form the contours and constraints upon academic, policy and activist debates about security.

This chapter fleshes out the notion of security as a discourse, which forms the ontological idea central to this study. Drawing upon poststructural ideas, it will be argued that security is a performative discourse constituted through 'reiterative and citational practice'.6 However, many poststructural accounts of security are interested in how particular conceptualisations become dominant. To better explore marginal discourses - such as those of an NGO - a more effective theoretical framework, drawing upon ideas about signification will be elaborated. The performance of security discourse is partially made up through a series of (re)significations. Recognising these interrelated signifiers allows analysis of various contexts, and the way that they shape connotations and senses of security. As argued by Jef Huysmans, approaching security as a signifier enables us to 'understand how security language implies a specific metaphysics of life.' That is, by examining the logics of security discourse, we can conceive of ways that "security" affects policy and political action: the 'signifier has a performative rather than descriptive force'. ${ }^{8}$ It will become apparent that the signification of security is product/ive of particular and specific ontological logics related to specific personalpolitical imaginations, and thus, a configuration of security embodies a politics. This critical review of the literature will support the analysis of security discourse in the remainder of the thesis by outlining the specific ontological underpinnings of various prefixes to "security".

The first two sections of this chapter survey competing ontological perspectives to "security". The narrative cores of competing discourses about/of security locating the referent subject within the state or the individual are explored. This investigation provides an insight into how the differing ontological perspectives have been assembled in opposition to each other, acting as a constraint upon the

'J. Butler Badies That Matker. On The Discursite Limits of "Sex"(Routledge, London, 1993), p. 6.

'J. Huysmans 'Security! What Do You Mcan?: From Concept to Thick Signifier' Exmpean Joumal of Intermational Relutions Vol, 4, No. 2 (1998), p. 231.

- Ibid., p. 232. 
debate. ${ }^{9}$ Further exploration of the ontological logics underpinning individual security highlights that discourses of individual security have been constructed either as an addition to, or a reconceptualisation of, state security discourse. The final part of the chapter offers an alternative way of thinking about security, inspired by the idea of security as a discourse. Analysis will draw upon divergent ways of viewing the discursive logics of security: security as a "speech act" where utterances securitize an issue, or as a performative discourse. From this, a feminist-poststructural framework will be formulated, building on notions of performativity and signification. This framework will act as the vehicle for the deconstruction of the ontological logics of the gender security discourse signified, articulated and represented in different ways by activists from feminist and women's NGOs in Serbia.

\section{SECURITY = NATIONAL/STATE}

Narratives about security during the Cold War were dominated by the perception that IR was a 'realm of strategic vision that would immunize protected spaces from unwanted penetrations'. ${ }^{10}$ However, these visions are not just a story that belongs to the Cold War: the modern realist, liberal and their neo- versions of security studies are shaped by centuries of philosophical legends, providing an 'effective genealogical sleight of hand' reproducing a status as the "rational" orthodoxy." Rallying cries from this apparent orthodoxy are still heard in the "post" Cold War era.12 Most realist and liberal theories of international politics incorporate stories about state sovereignty, interwoven with strategic schemes to protect this sovereignty. In these narratives, the sovereign state is the chief referent subject that is to be secured, or can act as a means of securing. The emphasis upon the state forms an ontological perspective about security that is dominated by a focus on structural and systematic factors as a cause of insecurity; insecurities which in some way can be prevented or alleviated through strategies of militarization and/or cooperation.

\footnotetext{
'L. Hansen 'Gender, Nation, Rape: Bosnia and the Construction of Security' International Feminist Journal of Politics Vol. 3, No. 1 (2001), p. 58.

${ }^{10}$ C. Sylvester Feminist Theory and Intemational Relations in a Pastmodem Era (Cambridge University Press, Cambridge, 2002), p. 169.

1' L. J. Shepherd Gender, Violence and Secwrity: Discourse as Practice (Zed Books, London, 2008), p. 56.

12 Realism in particular claims to be a timeless theory that remains relevant to making sense of international politics: see B. Buzan 'The timcless wisdom of realism?' in S. Smith, K. Booth and M. Zalewski (cds.) Intemational Theon: Poritizism und Beyond (Cambridge University Press, Cambridge, 1996) pp. 47- 65. Recent undergraduate textbooks on international relations theories, such as T. Dunne, M. Kurkj and S. Smith Intemational Retations Theuries: Discipline and Diversigy (Oxford University Press, Oxford, 2007) include chapters on realism, liberalism and their neo- variants, each with a scction on applying the theory to a "new" problem, such as the 2003 Iraq war or IMF conditionality. In addition, the continued academic practice/expectation (myself included) of the need to discuss realist and liberal theories of international relations in overviews of the relevant literature, even if only to voice a disagreement before (re)constructing a "new" theory. These conventions suggest that like it or not, "classical" international relations theories about security are stuck with us, and even, as Ken Booth reminds us, remains 'one of the ideas that academically made us' as security studies scholars. See Booth Theory of World Security, pp. $32-33$.
} 
The core of this particular set of narratives about security is the belief that the state is sovereign, and its sovereignty is paramount because it is a way of ensuring security. For realists, the state is a way of providing security because we have deferred to a powerful sovereign in a contract to protect us from a life that is 'solitary, poor, nasty, brutish and short'.13 The powerful sovereign in much of realist theory is the state. Liberal stories suggest that state interactions are bound by 'legal and moral rules' and even, in some cases, ${ }^{14}$ that war may play a role in the maintenance of an international order compromised of sovereign states. ${ }^{15}$ The concentration upon statism in both approaches imply that the main threat to security is war, and do not necessarily include considerations about gender, poverty, human rights or the environment - to take a small sample - as a security concern. This is because the state will act as a protector, and as such, national/state ontologies about security are concerned with (re)producing state sovereignty as a means of creating security from the (structural) instabilities present in the international sphere. Critically, the state is the provider of security.

Liberal theories point to structural disparities that make war and political conflict more likely, especially where 'divergent fundamental beliefs, conflict over scarce material goods, and inequalities in political power' occur. ${ }^{16}$ These insecurities can be overcome through cooperation and harmony, which is possible where a consensus can be built. These notions of cooperation are expressed in theories about democratic peace, a range of approaches emphasising and centralising the political logics and values of a sovereign state. Democratic Peace Theory (DPT), a key liberal rationalist theory, is inspired by the Kantian principle of perpetual peace, where states transcend anarchy to conform and agree to a set of shared ideas. ${ }^{17}$ DPT in its current form emerged in the 1980s, strongly advocated by Michael Doyle. ${ }^{18}$ In 1983, Doyle argued that 'even though liberal states have become involved in numerous wars with non-liberal states, constitutionally secure liberal states have yet to engage in war with each other'.19 The liberal ontology that harmony and peace can be achieved through shared state values, privileges a state-centric view of security, where security can be

${ }^{13}$ T. Hobbes (ed. R. Tuck) Letiutban (Cambridge University Press, Cambridge, 1996), pp. 89 - 100.

14 This is not the case within liberal pacifist theories.

${ }^{15} \mathrm{H}$. Bull 'Society and Anarchy in Intemational Relations' (1966) in Der Derian, J., (ed.) Intermational Theory: Critical Investigations (Macmillan, Basingstoke, 1995) pp. 75 - 93.

16 A. Moravsik 'Taking Preferences Seriously: A Liberal Theory of International Politics' Intemational Organization, Vol. 51, No. 4 (1997), p. 517.

17 I. Kant 'Perpetual Peace: A Philosophical Sketch' in C. Brown, T. Nardin and N. Rengger (eds.) Intemational Relations in Political Thought: Texts frmm the Ancient Greetes to the First World War (Cambridge University Press, Cambridge, 2002), pp. 432-439.

18 M. Doyle, 'Kant, Liberal Legacies, and Foreign Affairs: Part 1' Pbilosopby and Public Affairs Vol. 12, No. 3 (1983), pp. 205 - 235. Part 2 is published in Philasopby and Public Affairs Vol. 12, No. 4 (1983), pp. 325 - 53.

19 Ibid., p. 213. 
determined through diplomatic choices taken by the state, acting within an international system made up of divergent and alike states.

Similar logics regarding state and international structures are present in the liberal institutionalist discourse, an approach which has many affinities with realism in terms of its utilitarian and supposedly rationalistic reasoning. ${ }^{20}$ Robert Keohane and Lisa Martin suggest that institutionalist theory is 'highly applicable' to issues regarding security because 'its argument revolves around the role of institutions in providing [and sharing] information'.21 Under certain conditions, such as 'significant common interests', states may embrace the possibility of joining forces in order to amplify relative gains, including the prospect of achieving security.22 A conviction that states are seeking to maximise 'expected utility' highlights a narrative emphasising state-centric logics of security that construct a worldview where states act as securitizing forces. In contrast, realist and neo-realist strategies for achieving security arise out of ontological concerns with the contours of state behaviour, shaped by (self-interested) human nature or by structural instabilities inherent in the international/state system.

Classical realists such as Hans Morgenthau suggest that state insecurity is based upon the selfinterested qualities of human nature. ${ }^{23}$ A key manifestation of the concern about the self-interested nature of humans within realist security analysis is the security dilemma. First expressed by John Herz in 1950, the security dilemma describes the notion that anarchy is inescapable because states are only concerned with their own security needs, resulting in insecurity for others, as each state interprets its own measures as defensive and the measures of others as potentially threatening. ${ }^{24}$ Statism within an international system dominated by anarchy means that states concern themselves with issues of survival, and do not take other states into consideration when strategising about how best to defend themselves. ${ }^{25}$ The defensive action is perceived by other states as a threat to their survival: and so the vicious defence/threat circle continues. ${ }^{26}$ As a consequence, realists are pessimistic about the possibility of long-term stable peace, and the only way to survive is through military strength. During the Cold War, the discursive privilege enjoyed by realist ideas surrounding

\footnotetext{
${ }^{20}$ R. O. Keohane, L. L. Martin, 'The Promise of Institutionalist Theory' Intermational Security, Vol. 20, No. 1 (1905), p. 39.

${ }^{21}$ Ibid., p. 43.

22 Jbid., p. 39 and $43-44$.

${ }^{23}$ H. J. Morgenthau, Politics Among Nutions: The Struggle for Power and Peate (McGraw-I Hill, Boston, 1903).

${ }^{24} \mathrm{~J}$. Herz, 'Idealist Internationalism and the Security Dilemma' World Politics, Vol. 2, No. 2 (1950), p. 157.

25 Ibid., pp. $157-180$.

$26 \mathrm{lbid}$.
} 
the security dilemma meant that policy-makers felt that 'security was synonymous with nuclear deterrence and nuclear power balancing', ${ }^{27}$ In realist narratives prioritising the discursive status of a self-interested human nature, militarization is an inevitable consequence of the 'fundamental social constellation' where groups strive to 'attain security' by acquiring more and more power. ${ }^{28}$

Ontological worldviews of a chaotic international realm dominated by self-interested states penetrate structural realist theory. Since states 'do not enjoy even an imperfect guarantee of their security unless they set out to provide for it themselves', the international realm becomes a zero-sum game utilising balance of power survival strategies. ${ }^{29}$ These accounts point to the decentralised and anarchic international system, reliant upon state action to function. ${ }^{30}$ For structural realists such as Kenneth Waltz, structures explain the divergence between the international and national realms of politics. ${ }^{31}$ The anarchic international structure results in insecurity: it is the responsibility of the state to secure security. Since the international system is one of self-help, the best way to improve security is through balance of power, a theory about state actions, resting upon expectations of how other states behave. ${ }^{32}$ Similar views are advocated by John Mearsheimer, who argued that 'the keys to war and peace lie more in the structure of the international system than in the nature of individual states': war is a consequence of uneven military power. ${ }^{33}$ Military power is shaped by the structures of the international system, and Mearsheimer feared that the end of Cold War bipolarity - a structure that balanced military power - would mean more insecurity in a multipolar world. ${ }^{34}$ The neo-realist sketch of international relations and the apparently "inevitable" militarization deriving from self-interested states provides for a logic of security placing the state at its heart.

State-centric ontological perspectives about security emphasise the possibilities for the state to provide security within an anarchic international system, where harmony is possible for liberals, but not so for realists. Depending upon the epistemological standpoint about the structure of the

27 J. A. Tickner, 'Re-visioning Security' in Intemational Relations Theory Todiyy (eds.) K. Booth and S. Smith (Polity Press, Cambridge, 1995), p. 177.

28 Her\%, 'Idealist Intemationalism and the Security Dilemma', p. 157.

${ }^{29}$ K. N. Waltz Mun, the State, and War: A Theortical Anatysis (Columbia University Press, New York, 2001), p. 201.

${ }^{30}$ K. N. Waltz Theny of Intermational Politics (McGraw Hill, Boston, 1979), p. 88.

3t Ibid., pp $102-117$.

32 Ibid., p. 117, 122.

${ }^{33}$ J. J. Mearsheimer 'Back to the Future: Instability in Europe after the Cold War' Intermational Security, Vol. 15, No. 1 (1990), p. 12.

14 lbid., pp. 6 - 7 . 
international system and the way that states respond to this structure, different strategic visions exist about how to react: from militarization to interdependence. These analyses, as rich, subtle and diverse as they are, variously reproduce senses of state-centric militarised threats and/or solutions. The neorealist narrative, in particular, dominated security studies during the $1980 \mathrm{~s}$ when increased concerns of U.S. - Soviet conflict 'produced an explosion in foundation support for research on international security', ${ }^{35}$ It is this hegemony that (re)produced the neo-realist ontology as orthodoxy, as well as strongly linking its concerns to Cold War politics. From their vantage point in 1988, Joseph Nye and Sean Lynn-Jones in their survey of the field voiced a concern with the perceived lack of clarity with the "new approaches" to security, but at the same time, they criticised the preoccupation with strategy and deterrence, calling for more 'theoretical innovation'.36

There have been attempts by several scholars, including Barry Buzan, Richard Ullman and Jessica Tuchman Matthews to broaden the neorealist conception of security to include a wider range of threats'. ${ }^{37}$ These debates that are considered to broaden or widen the security studies agenda maintain its state-centric focus, but urge for a consideration of non-military threats to the state, including environmental, terrorist, migrant, and economic threats. For example, Richard Ullman advocates a redefinition of security to include concerns about the quality of human life outside of the military sphere, since policymakers, politicians and scholars all have an 'excessively narrow and excessively military' sense of security. ${ }^{38}$ This hyper-militarised perception is 'misleading' and 'dangerous' because by focussing only on military threats, other dangers are ignored and 'pervasive militarization' occurs within international politics. ${ }^{39}$ Redefining the meaning of national security to include natural and economic threats would ensure that more financial and time resources were devoted to other probable threats affecting the quality of human life.40 In this analysis, Ullman's referent subject remains the state, as the state is required to provide security, and decisions are made to protect the citizens of that state from threats. Despite maintaining a connection to state-centric security concerns, such works have come under fire from hardcore neo-realists for 'taking [the field of] security studies away from its traditional focus and methods... making the field intellectually

\footnotetext{
${ }^{33}$ J.S. Nye and S. M. Lynn-Jones 'International Security Studies: A Report of a Conference on the State of the Ficld' International Security Vol. 12, No. 4 (1988), p. 20.

${ }^{36}$ Ibid., pp. 21 and 26.

${ }^{37}$ K. Krause and M. C. Williams 'Broadening the Agenda of Security Studies: Politics and Methods' in Mershon Internutional Studies Rerrew Vol. 40, No. 2 (1996), p. 230. See B. Buzan., People, Stales and Fear. An Agenda for Security Siudies in the Past-Cold War Era (Lynne Rienner, London, 1991), R. Ullman 'Redcfining Security' Intemational Security Vol. 8, No. 1 (1983) pp. 129 - 153 and J. M. Tuchman 'Redefining Security' in Foreign Affairs Vol. 68 (1989), pp. $162-177$.

3 Ullman 'Redefining Security' p. 129.

39 Ibid., p. 129

40 Ibid, pp. 129 - 153.
} 
incoherent and practically irrelevant' upon issues of security strategy. ${ }^{41}$ Imagine then, the (negative) reaction of many state-centric security analysts to the (re)emergence of the 'deepening' agenda of security studies, where the referent subject is located, to some extent, within the individual and/or the international.

\section{SECURITY = INDIVDUAL/INTERNATIONAL}

During the 1970s and 1980s, the normative counterpoint to Strategic Studies was Peace Research, a field embodying concerns with nuclear deterrence, arms control and structural violence. ${ }^{42}$ While 'security' is not a significant concept in Peace Research, many of the individual approaches to security have developed - albeit indirectly - from ideas and theories within Peace Research..$^{43}$ At the centre of Human, Critical and some Feminist approaches to security is the individual, but tensions exist about bow individual security can be best achieved. These ontological tensions are concerned with the extent to which state sovereignty is challenged. This section outlines three variations of individual security discussed in this thesis, and how each approach perceives the role of the state in relation to the achievement of individual security. First, Human Security approaches are outlined, highlighting the call for an expansion of security concerns so attention can be paid to human welfare, but the primacy of state sovereignty is left unchallenged. ${ }^{44}$ Attention then turns to Critical Security Studies (CSS), where scholars urge for a reconceptualisation of what "security" means, and all structures upholding "dominant" security narratives, including structures of state sovereignty. Finally, a brief discussion of some Feminist Security Studies (FSS) approaches will highlight how FSS can be seen as a microcosm' of the broader field of Security Studies, while retaining a concern with the gendered individual.45 As will become especially apparent in part two of this study, several gender security approaches echo the ontological logics of Human Security or CSS, reflecting a particular position about how gender security will be achieved.

\section{Addition: Human Security Studies}

The notion of Human Security has been 'promoted from a strong institutional base', within the UN, and is a useful 'rallying point for a diversity of political actors seeking to boost support for

\footnotetext{
"1 Krause and Williams 'Broadening the Agenda of Security Studies' p. 230.

42 B. Buzan and L. Hansen The Evolution of International Security Siudies (Cambridge University Press, Cambridge, 2009), pp. 101 - 34.

43 Ibid., pp. 102-3.

44 E. Newman 'Critical Human Security Studies' Reties of International Stwdies Vol. 36, No. 1 (2010), p. 79.

45 Ibid., p. 208.
} 
development issues and humanitarian foreign policies'.46 Broadly, "human security" seeks to 'place the individual - or people collectively - as the referent of security, rather than, although not necessarily in opposition to, institutions such as territory and state sovereignty'. ${ }^{47}$ The balance sought by human security approaches aim to address the insecurity of the individual, while still retaining a sense of state sovereignty. It is this perceived balance that makes Human Security a useful entry point for some policy-makers within international institutions like the UN. The notion of Human Security enables examination of divergent interests and relations with a wide range of individuals, uncovering the 'social, economic and political factors that promote or endanger their security'.48 Human Security is not a coherent approach: conceptualisations 'may reflect different sociological/cultural and geo-strategic orientations'. ${ }^{49}$ Debates persist over the definition of Human Security, and how (if we should) measure insecurity. ${ }^{50}$ In sum, Human Security encompasses a range of approaches where the state and/or international community is concerned with improving human welfare in a targeted way.

One common fable is that the Cold War's demise broke the intellectual waters restraining possibilities for individual security perspectives. In fact, research with human-centred logics of security was conducted in the field of development studies during the 1970s.51 However, literatures on security studies and in development studies were reconfigured in the "post" Cold War era to account for increasing concerns with interconnections between poverty and conflict. ${ }^{52}$ The United Nations Development Programme (UNDP) 1994 Human Development Report is a key turning point for conceptualisations of human security, critical in its early agenda-setting role. ${ }^{53}$ The UNDP defined human security as a concern with enabling people to 'exercise [their] choices safely and freely - and that they can be confident that the opportunities they have today are not totally lost tomorrow'. ${ }^{54}$ The main categories of threats to human security outlined by the UNDP include economic, food,

${ }^{46}$ Buzan and Hansen The Evolution of Intermational Security Siudies, p. 203 and 205.

${ }^{47}$ E. Newman 'I luman Security and Constructivism' Intemational Studies Perspectives Vol. 2 (2001), p. 239.

48 S. Ogata 'State Security- Human Security' UNU Public Lectures Fridtjof Nansen Memorial Lecture, December 2001 (United Nations University, Tokyo), p. 10.

49 Newman 'Human Security and Constructivism' p. 240.

s) Sce Security Dialogue Special Section: What is 'Fuman Security'? 35, 3 (2004), pp. 345 - 87, G. King and C. L. Murray 'Rethinking Human Security' Political Scitence Quarrerly, Vol, 116, No. 4 (2001-2002), pp. 585-610.

s1 Cited in D. Roberts Human Insecurity; Global Structwres of Violence (Zed Books, London, 2008), pp. 13 - 14.

\$2 M. Dufficld Global Govemance and the New Wars: The Menging of Development and Security (Zed Books, London, 2001), p. 35.

${ }^{53}$ UNDP Human Detrlopment Report 1994: New Dimensions of Humun Secwrity (UNDP, New York, 1994). On the primacy of the UNDP Human Development Report, see Booth Theory of World Secwrity, pp. 321 - 322, Roberts Human Iniecwrig: Glabal Structures of Vialence, p. 23 and C. Thomas 'Global governance, development and human security: exploring the links' Thind World Quarterby Vol. 22, No. 2, p. 163.

54 UNDP Human Detrelopment Report 1994, p. 23. 
health, environment, personal, community, and political security: a 'laundry list' so broad that Roland Paris felt it was 'difficult to determine what, if anything might be excluded from the definition of human security'.55 The ontological focus upon the individual overlaps with many of the concerns invoked in the field of development studies, resulting in what Mark Duffield described as a 'noticeable convergence between the notions of development and security... achieving one is now regarded as essential for securing the other'.56 Human Security approaches emphasise basic human needs, welfare and development: human security is an integral part of development.

Another dimension to Human Security studies has been a concern with what Edward Newman calls the assertive/interventionist focus of human security, describing actions taken to prevent violations of human rights. ${ }^{57}$ Where a state is committing human wrongs, the international community should reassert the security of the individual in the name of human security. When the state is not protecting its citizens, 'the international community has a legitimate right to lobby for change. State sovereignty still exists, but it is no longer a compelling deterrent against intervention to affect change'.58 Humanitarian intervention can be thought of as an 'extreme' form of human security in this sense. 59 Any sovereign prerogatives underpinning trans-regional, transnational and international threats to the maintenance of peace and security can be addressed through the rubric of human security. The ontological logics buttressing notions of human security, is interventionist and rests upon particular notions of community, as it is a concept of security 'based upon values', extending the 'security obligations of states beyond their borders'.60 The emphasis upon values regarding human welfare means that where states are failing to protect the welfare of human beings, the international community should protect individuals through strategies of assertion/intervention.

The Human Security debate invokes narratives about international communities and intervention, contributing to growing concerns with international governance and/or society. ${ }^{61}$ While Human Security approaches do not urge for fundamental reconceptualisation of the existing structures of

ss UNDP Human Development Report 1994, pp. 24 - 5. R. Paris 'Human Security: Paradigm Shift or Hot Air?' in Intemational Secunity Vol. 26, No. 2 (2001), pp. $90-1$.

s6 Dufficld Global Gatemance and the Nes Wars, p. 16.

57 Newman 'Human Security and Constructivism', p. 244.

st N. Thomas and W. T. Tow 'The Utility of Security: Sovereignty and Humanitarian Intervention' Security Dialogut Vol. 33, No. 2 (2002), p189.

39 G. Oberletiter 'lluman Security: A Challenge to International Law?' Global Govermane Vol. 11 (2005), p. 186.

$\infty$ bid.

61 Newman 'Human Security and Constructivism', p. 241. 
governance and international community, there is space for reconsidering current limitations of global governance. ${ }^{62}$ For example, David Roberts suggests reconfiguring the referent subject of security so it accounts for structural violence committed against the individual. ${ }^{63}$ Roberts points out that structural violence - infanticide, infant and maternal mortality and structural femicide, which includes dowry murder, honour killings and fatal female genital mutilation - cause more deaths than war and are avoidable. ${ }^{64}$ Human Security as a concept is radical in its relocation of the referent subject towards the individual, and even in reconsidering existing structures of global governance and international intervention. However, the Human Security model rests upon an international community made up of sovereign states, a model thought to offer a way of responding to challenges of 'upholding the contemporary international order without devaluing its most important function: safeguarding and improving the quality of life of those individuals and groups that constitute the state's reasons for being'.65 Human Security approaches claim that the model can reinforce and strengthen attempts to bring existing international structures, conventions and law in line with the requirements of today's world to address a broader range of insecurities.

The field of Human Security is based upon a logic of security where the insecure individual intersects with a foundationalist ontology emphasising an international community of sovereign states. Discourses assume that conceptions of state security are a 'necessary but not sufficient condition of human welfare', since 'the citizens of states that are "secure" according to the traditional concept of security can be perilously insecure'.66 At the start of 2010, some scholars suggested that human security ideas were beginning to move in a new direction. For Mary Martin and Taylor Owen, the human security discourse within the UN system had died, but a possibility for the EU to adapt a refined, 'second-generation', approach to human security was emerging. ${ }^{67}$ In contrast, Edward Newman viewed human security as very much alive and kicking, but demanded that a bridge be built between all approaches to security concerned with the individual, suggesting a convergence between Critical Security Studies and Human Security Studies, to develop a more theoretical model of Human Security. 68

\footnotetext{
62 Thomas 'Global governance, development and human security', p. 164.

${ }^{63}$ Roberts Human Insecurity, pp. $31-68$.

64 Ibid.

${ }^{65}$ 'Thomas and Tow 'The Utility of Sccurity', p190.

${ }^{66}$ Newman 'Human Security and Constructivism', p. 240.

${ }^{67}$ M. Martin and T. Owen "The Second Generation of Human Security: lessons from the UN and EU Experience" Intermutional Affuirs, Vol. 86, No. 1 (2010), pp. 211 - 214. See also M. Kaldor, M. Martin and S. Selchow 'I Human Security: A New Strategic Narrative for Europe' Intermational Affairs Vol. 83, No. 2 (2007), pp. 273 - 288.
}

${ }^{68}$ Newman 'Critical Human Security Studies', pp. $77-94$. 


\section{Reconceptualisation: Critical Security Studies.}

One reason that Human Security scholars come under fire is a consequence of its immediate policyrelevance. Newman suggests that the integration of Human Security into the mainstream of policymaking has reinforced, rather than challenged, existing policy frameworks'. 69 In other words, there has been no theoretical critique about state sovereignty or a serious reconsideration of international governance. This is a pressing concern for those associating themselves with Critical Security Studies (CSS). ${ }^{70}$ CSS scholars argue the UNDP's conceptualisation of security has been used by states for rhetorical effect rather than to fundamentally challenge the 'system that created the problem in the first place', 71 While critical approaches to security are wide-ranging and incorporate various epistemological and methodological approaches, under consideration here are approaches to CSS inspired by the Frankfurt School tradition of Critical Theory, following Robert Cox's often cited claim that 'theory is always for someone and for some purpose'. ${ }^{22}$ As such, CSS is .both a theoretical commitment and a political orientation', calling for a transformation in the way that "security" is understood. ${ }^{73}$ CSS argues that to genuinely transform the way security is comprehended, conceptualisations of security should begin from the individual, enabling violences of political and social justice to be noticed. "Security" should be understood through the lens of an individual human being: 'it is from the human need to protect human values that the term 'security' derives its meaning' ${ }^{74}$

At the heart of CSS is the connection between theory and practice, and the role of identity and morality in shaping politics: in other words, theory and practice entail political choices. To achieve a moral politics, a key starting point is the perception that individual life experience is the means of

69 D. Chandler 'Review Essay. Human Security: The Dog That didn't Bark' Security Dialogue 39, 4 (2008), p. 428.

\footnotetext{
w Please note the deliberate capitalization of Critical Security Studies. For an overview of critical approaches to security studies, see $\mathrm{K}$ Krause 'Critical Theory and Security Studies: The Research Programme of 'Critical Security Studies" Conperation and Conflict Vol. 33, No. 3 (1998), pp. 298 - 333 and c.a.s.e Collective 'Critical Approaches to Security In Europe: A Networked Manifesto' Security Dialogue Vol. 37, No. 4 (2006), pp. 443 - 450. Other critical approaches to security covered in this chapter include Feminist Security Studies, the Securitization theory developed by the so-called "Copenhagen School" and the post-structural understanding of security as a discourse developed. The c.a.s.e collective also highlight the existence of a "Paris School", which is not explicitly dealt with here as it deals with more internal security concerns, such as surveillance and the police. However, Jef Huysmans, who is frequently attributed to the "Paris School" has written some important pieces on the signification of "security", and his work is valuable to this analysis.
}

$"$ Booth Theory of World Security, pp. $321-327$.

72 R. W. Cox 'Social Forces, States and World Orders: Bcyond International Relations Theory' Millennium: Journal of Intemational Studies, 10 (1981),p. 128.

${ }^{73}$ K. Booth, cited in P. Williams 'Critical Security Studies' A. J. Bellamy (ed.) International Satiety and its Critics (Oxford University Press, Oxford, 2005), p. 137.

74 B. McSweeney, cited in P. Williams 'Critical Security Studies', p. 141. 
formulating our understanding of insecurities. ${ }^{75}$ Additionally, CSS scholars emphasise the importance of asking "how" questions, which are 'logically prior to "why" questions': in choosing particular courses of actions 'scholars have to understand the way in which certain options... acquire meaning or value'. ${ }^{76}$ In essence, this means that the (neo)realist inevitability of state insecurity is challenged through asking "how" a particular threat is constructed. ${ }^{77}$ Thus, CSS scholars are encouraged to reformulate a notion of security connected to experience: theories about (in)security should be based upon practice, a (moral) practice that is political. These intimate connections between theory and practice mean that CSS approaches believe that the prevailing order should be questioned, and should highlight the intimate connections between the supposedly abstract realm of theory and the social world'. ${ }^{78}$

Human morality guides identification of "security" for CSS scholars. Ken Booth argued that "security' is what we make of it', highlighting that "security" is created by intersubjectivities.7" While "security" is socially constructed, it is important to CSS scholars to name "security" and specify security threats. ${ }^{80}$ A failure to address 'word problems' makes it tricky to 'deal successfully with world problems'. ${ }^{81}$ However, it is immoral to 'go theoretical tiger-shooting' with definitions of security failing to emancipate individual human beings: we should carefully consider what we see and identify as a "security issue", being aware of subjective considerations affecting the snapshots we (do not) take in the study of International Relations. ${ }^{82}$ Arguably, just as in the field of Security Studies, academic International Relations often acts like the Prozac of the human sciences; it 'consoles in some areas, and energies in others, but its overall effect is to obstruct its takers from facing up to and dealing with what the great mass of humanity, and the rest of the natural world, need to suryive passably well'.83 Underpinning these ideas is the notion that identification of threats should morally arise out of human experience, morally threats should be identified and explicitly stated: morally "security" should emancipate human beings.

\footnotetext{
${ }^{75}$ R. Wyn-Jones 'Mcssage in a Bottle'? Theory and Praxis in Critical Security Studies' Contemporary Secwrity Poligy, 16, 3 (1995), p. 309.

${ }^{76}$ Krause 'Critical Theory and Security Studies' p. 317.

7 B. Buzan 'Rethinking Security After the Cold War' Cooperation and Conflict 32, 1 (1997), p.19.

78 Wyn-Jones 'Message in a Bottle', p. 299.

${ }^{79}$ K. Booth Secwrity and Self: Reflections of a Fallen Realist YVISS Occasional Paper 26 (Toronto, October 1994), pp. 15 - 16.

${ }^{80} \mathrm{~K}$. Booth 'Security and Emancipation' Retiew of Intemutional Simdies Vol. 17 (1991), p. 317.

s1 Ibid., p. 313

22 Ibid, pp. 313 - 314., and K. Booth 'Human Wrongs and International Relations' Intermational Affairs, Vol. 71, No. 1 (1995), pp. 103 - 126.

${ }^{83}$ Booth 'Human Wrongs and International Relations', p. 104.
} 
Central to the concerns of CSS scholars are ideas about emancipation. In a 1990 plenary address, Ken Booth urged scholars to visualise 'security and emancipation [as] two sides of the same coin'; a relationship that he now feels is more effectively explained by conceiving security 'as the means and emancipation as the end. ${ }^{84}$ Emancipation is a 'strategic process', and a 'tactical goal that requires specific policies and clever and committed human agency'. ${ }^{85}$ For Booth, emancipation 'seeks the securing of people from these oppressions that stop them carrying out what they would freely choose to do, comparable with the freedom of others' ${ }^{86}$ Freedom is accomplished by rejecting hegemonic power and order, as stable security 'can only be achieved by people and groups if they do not deprive others of it' ${ }^{87}$ The inherent ontological logic in this perception of security is that there is a structural force that individuals need to be emancipated from. For many CSS scholars, the sovereign state is the source of insecurity, as it 'is part of the problem rather than the solution'. ${ }^{88}$ The emphasis upon protecting state sovereignty is not only a source of insecurity, but means that our eyes are averted from the real problems. To orientate the referent subject of security away from the state and towards the individual is a moral path of action enabling individuals to be emancipated.

CSS posits itself as the opposition to strategic and state-centric security studies, taking the position that it is 'deeply subversive of the ruling orthodoxy' on security. ${ }^{89}$ 'The approach claims to have 'both a theoretical commitment and a political orientation', with a theoretical commitment to embrace connections between theory and practice alongside a political orientation concerned with ideas about emancipation and community.90 For scholars of CSS, morality, justice and politics connect together concerns about locating the referent subject of security in the individual, alongside an ontological perspective emphasising the role of structures in shaping both our worldview and our world. Some feminist security studies scholars share such perspectives, most notably Ann Ticker and Cynthia Enloe. While most feminists describe themselves as critical theorists, those influenced by and influencing 91 ideas contained within CSS, point to the gendered structural inequalities that 'manifest

\footnotetext{
${ }^{4}$ Booth 'Security and Emancipation' p. 319, Theory of World Security, p. 115.

${ }^{85}$ Williams 'Critical Security Studies', p. 140

*6 Booth Theory of World Security, p. 112.

87 Booth 'Sccurity and Emancipation', p. 319.

${ }^{86} \mathrm{Wyn}$-jones "Message in a Bottle', p. 310.

89 Jbid. p. 309.

${ }^{0}$ Booth, ctted in Williams 'Critical Security Studies', p. 137.

${ }^{r}$ Ken Booth in particular has been influenced by many feminist ideas.
} 
themselves across societies and history'.92 Some feminist analyses of security seek to make sense of the gendered structures that are in place, and work to 'denaturalize and dismantle them'. ${ }^{93}$ For both CSS scholars and many Feminist Security Studies (FSS) scholars, there is an intrinsic connection between the personal and the political.94

\section{Gendering Security}

While there is a branch of FSS ontologically close to CSS, FSS is by no means a coherent school of thought. FSS is better viewed as a 'microcosm' of the broader security studies field: a microcosm concerned with the gendered individual. ${ }^{95}$ Laura Sjoberg identifies several commonalities amongst FSS approaches. First, the 'analyses and reformulations of the traditional contexts of Security Studies', questioning 'what counts as a security issue and to whom the concept of security should be applied to'. ${ }^{96}$ Second, FSS seeks to understand 'the gendered nature of the values prized in the realm of international security': images of masculinity and femininity influence how 'scholars and policymakers frame and interpret issues of international security'.97 Finally, the ways in which gender operates in the theory and practice of international security: gender 'adds something to Security Studies', and is also 'a transformative force in the constitution of security'. ${ }^{98}$ Critically, FSS exposes the omission of gender does not equate gender neutrality. ${ }^{99}$ Debates within FSS focus upon understanding what "gender security" is, why these insecurities exist, and how to address these insecurities. The particular logic of gender security put forward stimulates and constrains actions, policies and practices relating to, or dealing with, gender security.

\footnotetext{
92 J. A.'Tiekner 'You Just Don't Understand: Troubled Engagements between Feminists and IR 'Theorists' Intemational Siudies Qwarterly Vol. 41, No. 4 (1997), p. 624.

${ }^{23}$ Ibid.

${ }^{24}$ Booth Secwrity and Self: Reflections of a Fallen Realist, pp. 3-4.

${ }^{95}$ Buzan and Hansen The Evolution of Intermational Security Siudies, p. 208. See C. Einloe Bananas, Beaches and Bases: Making Feminist Sense of Intermational Politics (University of Califomia Press, Berkeley, 2000), J. A. Tickner Gender in Intermational Relations: Feminist Perspectives on Acbiening Global Secwrity (Columbia University Press, New York, 1992).

${ }^{6} \mathrm{~L}$. Sjoberg 'Introduction' in L. Sjoberg (ed.) Gender and Intermational Security: Feminist Perpectites (Routledgc, London, 2010), p. 4.

${ }^{97}$ Ibid, p. 5.

Ibid.

$99 \mathrm{Jbid}$
} 
The critical approach, advocated by Cynthia Enloe and Ann Ticker, has come to dominate many FSS concerns. ${ }^{100}$. Through an epistemology of experience, critical FSS approaches seek to make explicit the specific violence suffered by women, such as wartime rape and sex-trafficking. Critical FSS scholars highlight that understanding the security problems that affect individuals 'cannot be raised within a rationalistic framework' depending upon 'an ontology based on rational actors in a statecentric world'. ${ }^{101}$ Here lies the common ground with CSS approaches: both reject the rationalistic framework that is perceived to allow the discipline of security studies to ignore human wrongs, and wish to dismantle these state-centric structures to provide an entry point for consideration of the individual. By looking at the 'economic, political, social or personal circumstances of individuals' the possibility of tackling gender insecurity is made apparent. ${ }^{102}$ As Ann Tickner puts it, 'feminist approaches offer us new tools with which to question this exclusionary way of thinking, since security is defined very broadly 'in multidimensional and multilevel terms', noticing a wide range of violences. ${ }^{103}$ Like CSS approaches, the logics of security within some areas of FSS are based upon ontological concerns about the individual and gender. These critical approaches have extraordinary analytical strengths in problematising national/state security discourses by drawing attention to the discursive processes that construct security issues and threats, such as the presentation of "social facts" about human nature that supposedly shape the international system.

However, these critical FSS perspectives have been criticised for relying upon 'a deeply subjective, narrative and often emotional form of knowledge'.104 Some FSS approaches reflect a more poststructuralist concern, insisting upon a concern with the construction of a particular identity or image of "women", "men" or "gender". ${ }^{105}$ Woven through poststructural FSS approaches is a curiosity with the construction and representation of gender identities, and the effects of these identities. Poststructuralist feminist security approaches thus provide a rejoinder to the concerns about the focus of (critical) feminist security theory upon the individual, producing an optic through which everything can be said to be a security problem', as poststructuralist FSS aims to provide a 'critique [of the field of security studies for its inherent male biases and trac[ing] how particular political practices produce collective conceptualisations that constrict or enable what can be

${ }^{100}$ Buzan and Hansen The Evolution of Intemational Secwrity Sixdies, pp. $208-210$.

101 J. A. Tickner 'Feminist Responses to International Security Studies' Peace Revies Vol. 16, No. 1 (2004), p.43.

102 J. Steans Gender and Intemational Relations (Polity Press, Cambridge, 2006), p. 63; Hansen 'Gender, Nation, Rape: Bosnia and the Construction of Security', p. 58.

${ }^{103}$ Tickner Gender in Intemational Relations: Feminist Perspectives on Acbieving Global Security, p. 132 and You Just Don't Understand', p. 624.

104 Buzan and Hansen The Esolution of Intemational Security Studies, p. 209.

10 Hansen 'Gender, Nation, Rape', L. J. Shepherd Veiled Reference: Constructions of Gender in the Bush Administration Discourse on the Attacks on Afghanistan Post-9/11' Intemalional Feminist Joumal of Politics, Vol. 8, No. 1 (2006), pp. $19-41$. 
recognised as legitimate problems of the individual'. 106 'Thus, poststructuralist FSS retains a sense of the individual by locating analysis of the constructed individual within a collective entity, aiming to escape the dichotomies that constrain the debate about what constitutes a security problem.

A range of perspectives also exist in making connections between gender and Human Security. For Gunhild Hoogensen and Kirsti Stuvóy, a gender-informed human security approach, centralising gender, is more effective in highlighting specific insecurities arising from gender identity. Engendering the human security debate exposes 'securities and insecurities ranging from large-scale 'traditional' conflicts to those 'behind the closed doors' of the private sphere, including sexual and domestic violence'. ${ }^{107}$ These insecurities are uncovered through empirical knowledge. ${ }^{108}$ In contrast, other FSS scholars are concerned that engendering security could miss some critical areas, as there is no guarantee that gender would be routinely included as a category of analysis'. ${ }^{109}$ Advocates of a mainstreaming approach, including Heidi Hudson, insist that to avoid the universalising tendencies of both critical FSS and Human Security approaches, it is necessary to develop a theory of 'gender in human security".110 By taking "gender" as a central identity, Human Security approaches can avoid the universalising tendencies that arise when the "human" (presumed male) is taken as the analytical crux, "highlighting the dangers of masking differences under the rubric of the term "human" ensuring a more nuanced perception of (in)security problems. ${ }^{111}$ Debates about the inclusion of gender in Human Security approaches are concerned with how gender should be considered: as an isolated gender-specific security problem, or across all security problems.

These ontological differences matter as each offer different perspectives about what "gender security" looks like, and the path taken to achieve it. The range of approaches about gender security reflects the range of ontological and epistemological logics guiding interpretations of gender security and UNSCR 1325 amongst feminist and women's activists in Serbia. To analyse the logics undérpinning various perspectives of gender security, the notion of security as a discourse is utilised.

\footnotetext{
${ }^{106}$ L. I Iansen and L. Olsson 'Guest Editors' Introduction' Security Dialogue, Vol. 35, No. 4, (2004), p.405.

${ }^{107}$ G. Hoogensen and K. Stuvóy 'Gender, Resistance and Human Security' Security Dialogue Vol. 37, No. 2 (2006), p. 225.

108 Jbid.

${ }^{100}$ H. Hudson 'Doing' Security As Though Human Matter: A Feminist Perspective on Gender and the Politics of Human Security' Security Diulogue Vol. 36, No. 2 (2005), p. 161.

110 Ibid., pp. $155-174$.

11']bid.
} 


\section{SECURITY = DISCURSIVE/PERFORMATIVE}

Individual approaches to security have drawn attention to how state-centric logics of security have affected security concerns, but, almost unwittingly, have fallen into their own trap which is as ideologically loaded. While Ken Booth dismisses such criticisms as 'predictable', an individual/international approach to security simply replaces one power structure with another. ${ }^{112}$ The result is that state and individual security approaches are pitched in direct opposition against each other. These tensions 'constrain the debate', reproducing an either/or dichotomy. ${ }^{113}$ At the same time, I wish to utilise feminist critiques encouraging us to have a gendered curiosity about the world. After all, it takes a feminist curiosity and gender-analysis skills to lift up these two heavy rocks of national security studies and policymaking so we can critically scrutinize what ideas lie under both of them'.114 There is no need to throw gender out with the bathwater. By lifting up increasingly heavy rocks of various individual approaches to security studies, it is possible to deconstruct how, how far, and why ideas about gender security have (possibly) begun to take hold within various individual/international approaches to security. To investigate how gender security is performed and signified, I draw upon a curiosity about how constructions of gender govern and limit the practices of security, and vice versa. ${ }^{115}$ This framework provides a useful entry point into the issues dealt with in this thesis, as it recognises that feminist security perspectives are constructed within different sites of political authority, and thus, "gender security" is thought about in different ways.

Understanding how the meaning of security is discursively constructed requires a conceptualisation of "security" 'as having no independent reality outside the world of social relations through which 'it' is constituted and sustained'. 116 While much has been done to deconstruct the discursive terrains of security that preoccupy state elites, foreign policy and international organisations, surprisingly little research has been conducted into the security discourse of marginal groups and/or grassroots organisations, and the impacts that these discourses may (not) have. ${ }^{117}$ As a consequence, much of the framework which conceives of security as a discourse needs to be explicitly theorised to allow for a poststructuralist interpretation of grassroots action and agency. As stated in chapter one, a

\footnotetext{
112 Edkins 'After the Subject of International Security', pp. 68 - 9.

11 Hansen 'Gonder, Nation, Rape', p. 58.

114 C. Enloe Globaliquation and Militarism: Feminists Make the Link (Rowman and Littleficld, Lanham, 2007), p. 60.

I1s Hansen 'Gender, Nation, Rape' p. 59.

116 I ligate and Henry Insecun Spuces, p. 100.

117. Notable exceptions to this include R. L. Doty 'States of Exception on the Mexico-U.S. Border: Security, "Decisions," and Civilian Boarder Controls' International Political Sociology Vol. 1, No. 2 (2007), pp. 113 - 137 and chapter five, 'Feminist homesteadings of security and cooperation' in C. Sylvester Feminist Theory and International Relations in a Pastmodem Era (Cambridge University Press, Cambridge, 1994).
} 
discourse is best described as a system made up of significations, articulations and representations that make a meaning which is momentarily halted. To outline how security is conceived of as a discourse, this section will first criticise the notion of security as a "speech act" where utterances securitize an issue. The securitization perspective lapses into constructivist modes of thought, failing to fully elaborate how a security problem is made or undone. As such, I put forward an understanding of security as a performative discourse, where a cluster of significations "fix" the (temporary) meaning of security. The section concludes with a discussion of how gender security is viewed as a performative and signified discourse in this thesis.

\section{Securitizing security}

The notion of securitization is associated with the Copenhagen "School"118 of security studies, initially expressed by Ole Wrver."19 Here, I focus upon the idea of "speech acts" and utterances labelling an issue as a security concern. The notion of individual security is problematic for the selfconfessed 'post-structural realist', Wrever, as the concept of security refers to the state. ${ }^{120}$ For Wrever, individual or international security do not exist as concepts, rather, they are 'dynamics' affecting how security is conceptualised. ${ }^{121}$ Since the state and its security remains the primary focus, security has a 'semiotic identity', and can be regarded as a 'speech act', where the utterance of security is the act of making it a security issue. ${ }^{122}$.Explicitly saying "security" is not enough: there is a need to construct a plot or narrative which suggests that a security threat is present. ${ }^{123}$ The rhetorical nature of securitization is defined as a speech act consisting of 'existential threats, emergency action, and effects on inter-unit relations by breaking free of the rules'.124 Securitization theory recognises the discursive terrain constructed around security, successfully demonstrating the political saliency of security'as a concept. However, the epistemological reliance upon utterances and speech acts raises concerns

\footnotetext{
"18 I insert speech marks around "school" to cast uncertainty over the idea of a complete, coherent school of thought. The scholars associated with the Copenhagen School are influenced by a diverse range of theoretical approaches - from Buzan's neorealism to Waver's poststructural curiosity - and to cast them all into the same mould would be to miss a sense of 'creative development' that is present in the work Prom these scholars throughout the 1990s. See J. I luysmans 'Revisiting Copenhagen: Or, On the Crcative Development of a Security Studies Agenda in Europe' Eumpean Journal of International Relations Vol. 4, No. 4 (1998), pp. 479 - 505.

119 O. Waver, 'Sccuritization and Desecuritization' in R. D. Lipschutz (ed.) On Seiwrity (Columbia University Press, New York, 1995), pp. 46 - 86 and B. Buzan, O. Waver and J. de Wilde, Security: A New Framework for Anabysis (J.ynne Rienner, London, 1998.

${ }^{120}$ c.a.s.e collective, 'Critical Approaches to Security in Europe: A Networked Manifesto' Securiy Diulogue 37 (4), p. 452 . Although he describes himself as a post-structural realist, in the two studies examined in this chapter, I see Waver's position as more social constructivist than poststructural. I have included these ideas because of the epistemological discussion of (or reliance upon) discourse, although Waver's ontology differs from the poststructural positions outlined shortly.

121 Waver, 'Securitization and Desecuritization', pp. 48-9.

122 lbid, pp. 50 - 5.

${ }^{123}$ Buzan et. al., Secwrity, p. 27 and 33.

$124 \mathrm{Ibid,}, \mathrm{p} .26$.
} 
about the way that the discourse of security is constructed, and the role of subjectivity in discursive construction.

The emphasis upon utterances gives epistemological privilege to actual speech acts of an actor, presupposing a teleological and singular discursive construction. This constructivist conception of security harks at a belief that merely by changing the way that policy-makers think and speak, the world would be automatically different. Although this highlights the transformative impacts of a discourse, it ignores the historical roots and the contextual relationships embedded in the construction and reconstruction of security discourse. In addition, as pointed out by Lene Hansen, the dependence upon utterances 'presupposes the existence of a situation in which speech is indeed possible', provoking questions about the security of those 'constrained in their ability to speak'.125 Drawing on the example of honour killings and rapes in Pakistan, Hansen points out that if a woman acknowledges the rape, she not only places her own security at risk, but also the women immediately around her. ${ }^{126}$ As a consequence, the 'security strategies chosen by Pakistani women have... often been silence, denial, or... flight'. ${ }^{127}$ Even where local women's groups and international organisations like Amnesty International have vocalised dissent with the practice of honour killings, it is difficult to say that they are successfully securitizing the issue in the way defined by the Copenhagen School, because these campaigners do not escape the norms and rules in the context faced by these insecure women. ${ }^{128}$ The School's analytical reliance upon speech acts means that the theory cannot elucidate upon the historical contexts surrounding in/security concerns.

A problematic idea arising out of the Copenhagen's "School" securitization theory concerns the notion of collective subjectivity. Poststructuralist feminists tend to question the idea of the subject and subjectivity, querying 'that there is an essential subject to be discovered', and 'cast doubt on the political effectiveness of insisting that there is an essential subject of women within whom identity politics and rights claims can be located'.129 For Wrver, Buzan, and de Wilde, an issue is securitized 'only if and when the audience accepts it as such', requiring some form of general agreement, whether

\footnotetext{
125 L. Hansen 'The Little Mermaid's Silent Security Dilemma and the Absence of Gender in the Copenhagen School' in Millennium: Jourmal of Intemational Siudies Vol. 29 No. $2(2000)$ p. 285 and 287. Lene Hansen also raises other gendered poststructural criticisms of the Copenhagen School, such as the placing of gender in its level of analysis.

126 Ibid., p. 294

127 Ibid, p. 295.

129 Ibid, p. 295 - 7.

${ }^{129}$ M. Zalewski Feminism after Postmodemism: Theorising Through Practiat (Routledge, London, 2000), p. 40
} 
by coercion or consent. 130 Since 'security is determined by actors and in this respect is subjective... securitization is intersubjective and socially constructed', 131 To be successfully securitized, collective agreement is required, since 'security ultimately rests neither with the objects nor with the subjects but among the subjects'. ${ }^{132}$ That is to say, an issue is only defined as a security concern when a social group collectively decides that it is a security matter. These ideas are potentially useful in explaining why an NGO would choose to articulate and represent its security discourse: there is a perception that it is possible to raise awareness and even "securitize" an issue through getting an audience to listen and accept their ideas.

However, there are two issues with the perception of collective security. First: the notion presumes a singularity of identity and debate: even with coercion, multiple and various identities about security need to be negotiated. Second: these ideas about collective security still hark at the notion that it is possible to merely change your language to change the world: there is little room in the theory for the existence of a (pre-existing) discursive field that these debates need to operate within. The notion of discourse-as-construction is problematic, as argued by Judith Butler, because constructivism reduces discourse to 'a position of linguistic monism, whereby linguistic construction is understood to be generative and deterministic'. ${ }^{133}$ Questions are triggered about how to account for human agency since the discourse becomes the subject. Furthermore, questions should be raised about the model of construction where the social unilaterally acts on the natural and invests it with its parameters and meanings'.134 In other words, conceiving of security as a speech act constructed upon what already exists does not radically shake the foundations upon which security is built upon, or fully address questions about how structures are undone and come about. The alternative to constructivism is to consider ways that discourses are performative, which 'moves us away from a reliance on the idea of (social) construction towards materialization, whereby discourse... constitutes both subjects and objects'. ${ }^{135}$

\footnotetext{
${ }^{130}$ Buzan et. al. Security p. 25.

${ }^{131}$ Ibid, p. 31 .

132 Ibid.

133 Butler Bodies That Matter, p. 6.

134 Ibid., p. 4.

${ }^{135}$ L. Bialasiewicz, D. Campbell, S. Elden et al. 'Performing Security: The Imaginative Geographies of current US Strategy' Political Geograply Vol. 26 (2007), p. 407.
} 


\section{Performative and Signified Security}

Chapter one highlighted that a discourse is a system of meaning-making where the meanings attached to a material event affects the constitution of the discourse. That is, discourse affects the conceptualisation of an object. ${ }^{136}$ Discourses involve 'the ideal and the material, the linguistic and non-linguistic' and as such, 'discourses are performative'.137 Judith Butler has explored the way that gender is discursively performed. ${ }^{138}$ For Butler, gender discourse 'operates as an interior essence that might be disclosed, an expectation that ends up producing the very phenomenon that it anticipates... is not a singular act, but a repetition and a ritual, which achieves its effects through its naturalisation in the context of a body, understood, in part, as a culturally sustained temporal duration'.139 Clarifying this further, Butler highlights that performativity is not 'the act by which a subject brings into being what she/he names', but, rather, as the 'reiterative power of discourse to produce the phenomena that it regulates and constrains'.140 The key point to draw out here is the idea of repetition, reiteration, and ritual as discursive practices/processes that construct a discourse. This allows for a theorisation of discursive change(s) as well as stabilization(s). Discourses are product/productive of a range of discursive practices around the object. For example, states 'are made possible by a wide range of discursive practices that include immigration policies, military deployments and strategies, cultural debates about normal social behaviour, political speeches and economic investments'. ${ }^{141}$ Conceived as performative, a discourse is not something that merely builds upon what already exists, but is something that is repeated and/or modified over time through discursive practices, and is momentarily, partially fixed before being reproduced and reconstituted.

Thinking of "security" as a performative discourse challenges how we conceive of security, enabling us to refer to a broader 'framework of meaning.' ${ }^{142}$ Security is no longer limited to concerns about a referent subject, such as the state or the individual: rather, ways in which "security" is temporarily fixed (to a referent object) through discursive practice is analysed. Through its performance, we can explore ways in which security discourse is product/productive of the way we imagine social and political realities. Emphasising that security is a performative discourse means that we begin to ask

\footnotetext{
136 Laclau and Mouffe Hegemony and Socialist Sirategy, p. 108.

${ }^{137}$ Bialasiewicz et. al. 'Performing Security'? p. 406.

130 J. Butler Gender Trouble (Routledge, London, 2001), Bodies That Matler and Exritable Speech: A Politics of the Petfomative (Routledge, London, 1997).

${ }^{139}$ Butler, Gender Tmuble, p. xv

140) Butler Bodies That Matter, p. 2.

141 Bialasiewicz et al. 'Performing Security' p. 406.

${ }^{142}$ Huysmans 'Securityl What Do You Mean?', p. 228.
} 
questions about why the discourse of security is invoked, how security functions, and ways that security discourse is (re)produced in particular ways in certain contexts - in theory, policy and practice. For example, in his study of how security is constituted through US foreign policy and identity, David Campbell looks at how the early Cold War period constructed Communism as a security concern for the US. ${ }^{143}$ In the late 1940s, the articulation of danger from the Soviet Union 'coalesced' around loyalty and ideological purity, through practices including loyalty oaths to weed out those 'who professed un-American beliefs'.144 By the early 1950s, following Eisenhower's 1953 Executive Order linking national security to loyalty to the US, loyalty became a national security concern. ${ }^{145}$ Campbell argues that a rationalist assessment of the impacts of this Executive Order would not "fully appreciate the social and political effects it had on inscribing the boundaries of identity', as the Order built upon pre-existing practices to reproduce a security concern.146 Campbell's analysis highlights ways state identity was (re)constituted in the name of security. Viewing security as a performative discourse has implications for our understanding of how "security" is (temporarily) fixed, and the importance of pre-existing practices in the making and undoing of "security".

Understanding security as a discursive process and practice that is product/productive of repetition, reiteration, and rituals stabilizing 'to produce the effect of boundary, fixity, and surface that we call matter' is useful for poststructural analyses exploring elite/"powerful" security practices: for example, studies of US foreign policies or understanding responses to the Bosnian war. ${ }^{147}$ However, if we are to assess Butler's notion of performativity critically, problems arise in the way that she allegedly 'jettisons agency altogether'. ${ }^{148}$ Lise Nelson argues that since Butler 'conceives of conscious agency as stemming from an autonomous (pre-discursive) subject... she makes no place for conscious agency.149 This raises questions about how to explain the deliberate discursive interventions of activists: an issue of concern in this thesis as some gender security discourses have been deliberately articulated and represented as a challenge to (presumed) dominant security ideas. A perception which highlights how conscious agency operates within a performative discourse is necessary for the feminist-

${ }^{143}$ D. Campbell Writing Seckrity: Uniled Siates Fioneign Poligy and the Politics of Identity (Manchester University Press, Manchester, 1992), pp, 160 $-187$.

144 Ibid. pp. 168-71.

145 lbid.

146 Ibid., p. 172.

147 Two excellent and insightful examples: Campbell Writing Security, Hansen Security as Practice.

${ }^{148}$ L. Nelson 'Bodies (and spaces) do Matter: The Limits of Performativity' Gender, Plase and Cullure: Joumal of Feminist Geography Vol. 6, No. 4 (1999), p. 332.

${ }^{149}$ Jbid., p. 340. 
pacifist case study explored in chapter five. 150 Poststructural ideas about signs and significations are deployed to craft a theoretical framework where a conscious challenge can made to an apparently "dominant" performative discourse.

It was noted in chapter one that a discourse includes signifiers articulated as a momentarily fixed totality. Signifiers are points of partial fixation around which meanings are constructed, and along with these meanings, social order. This does not mean that signifiers will maintain a particular social order. Rather, it opens the possibility of a claimed emancipatory discourse when a discourse is in the business of producing a master signifier that will unsurp the reigning order'.151 Since discourses are unfixed at the same moment that they are fixed, any ideological formation (such as the discourse of security) is always incomplete, opening up possibilities for 'the production of new subject-positions, new political signifiers, and new linkages to become the rallying points for politicization'. 152 The production of "new" signifiers are product/productive of "prior instances of itself. 153 That is, any discourse of rebellion aiming to break away from dominant discourses of security is dependent upon the existence of a dominant discourse for its meaning. It is this dependence upon the pre-existing discursive field that suggests 'political signifiers might be avowed as performative.'154 Indeed, 'the ambivalent structure at the heart of performativity implies that, within political discourse, the very terms of resistance and insurgency are spawned in part by the powers they oppose'. ${ }^{155}$ By conceiving of security as a performative discourse, where signifiers are repeated, reiterated, and ritualised; clustering and interacting to construct a certain logic of security, it is possible to alter these logics of security - consciously or not - through resignification. A conscious resignification of "security" arises out of an opposition or resistance to the dominant discourse of security, and if effective, can modify the practice of security.

Recognising the signifier as a performative force affects the ways in which we analyse "security". Jef Huysmans argues that by viewing "security" as a signifier, the aim is to "lay bare the political work of the signifier security, that is, what it does, how it determines social relations'.156 Viewing "security" as

\footnotetext{
${ }^{150}$ Bialasiewicz et. al. 'Performing Security', p. 407.

131 Edkins 'After the Subject of International Security', p.80.

${ }^{152}$ Butler Bodies That Matler, p. 193.

${ }^{133}$ Quotation from Ibid, p. 220.

154 Ibid.

155 Butler Exritable Speech, p 40.

156 Huysmans 'Securityl' p. 228.
} 
a signifier enables us to 'start from the assumption that the category security implies a particular formation of questions, a particular arrangement of material... in a thick signifier analysis, one tries to understand how security language implies a specific metaphysics of life'.157 Since the logics of security have an intimate connection to the chain, or web of (re)significations about security, the social and political effects of particular meanings are exposed. These significations cannot float free from previous significations, and thus history and context are embedded within the discursive practices that surround the performance of security. Ultimately, security conceived as a performative discourse means that security is not just 'about survival'..., but about the production of referent objects and their constituent (and threatening) outsides'.158 The emphasis of analysis is placed upon bow a referent subject of security comes into being, which requires deeper investigation of personalpolitical imaginations that shape security discourse.

\section{Performance and Signification of Gender Security}

Recognising that identities and perceived social and political arrangements are product/productive of the performance of security discourse throws up questions about how discourses of gender operate in the performance and signification of gender security. In essence, discourses of gender and discourses of security are intertwined. Laura Shepherd argues that 'the performance of gender is immanent in the performance of security and vice versa' because both gender and security are conceived through (sometimes cohesive) ontological assumptions. ${ }^{159}$ For example, individual/international security highlights how violences are produced by the way that states are constructed. ${ }^{160}$ By (re)focussing the international system, these violences can be prevented, an ontological standpoint reflected in approaches to gender violence concerned with ways individuals are constructed. ${ }^{161}$ Therefore, when we pay attention to the performance of particular configurations of social/political order, we recognise ways security discourses 'perform an ordering function - not only in the theory/practice of security and the reproduction of the international, but also in the reproduction of gendered subjects'. ${ }^{162}$ That is, a gender perspective is (sub)consciously woven into our ontological viewpoint regarding the referent object of security, simultaneously as our perspective about security moulds

\footnotetext{
157 Ibid, p. 231.

158 Edkins 'After the Subject of International Security', p.79.

159 Shepherd Gender, V"ollence and Seiwrity, p. 172. See also L. J. Shepherd "Victims, Perpetrators and Actors' Revisited: Exploring the Potential for a Feminist Reconceptualisation of (International) Security and (Gender) Violence' British Journal of Politics and Intemational Relations Vol. 9, No. 2 (2007), p. 250.

${ }^{160}$ Shepherd Gender, Violence and Secwrity, p. 172.

161 Shepherd 'Victims, Perpetrators and Actors', p. 251.

162 Shepherd Gender, Violence and Security, p. 172. See also Shepherd "Victims, Perpetrators and Actors' p. 250.
} 
and/or delineates our standpoint about gender. Making and undoing a discourse of "gender security" relies upon particular performances and significations of "gender" and "security".

The intersection between performances and significations of gender and security construct a notion of "gender security". In relation to this thesis, this means that the security discourse of activists shapes, and is shaped by, their gender politics. Understanding that "gender security" is a performative discourse, where a cluster of significations fix the (temporary) meaning of gender security provokes several questions about what "gender security" might look like - and indeed, how we might approach security. First: should the notion of "gender security" highlight female experiences of insecurity or challenge constructions of gender identities? That is, who, and what is "gender security for? Second: should "gender security" concerns be mainstreamed or engendered? That is, bow can gender security be practiced? The responses to these questions have a significant impact upon how "gender security" is interpreted. Furthermore, deconstructing how a performance of a particular "gender security" discourse has been signified, represented, and articulated highlight how NGOs structure and conduct their debates and actions. Through addressing the political visions underlining the significations, representations and articulations of "gender security", we have an insight into how literal, linguistic and metaphorical networks, connections and reconfigurations impact upon the way gender security is imagined.

These performances of "gender security" are made possible, and limited by, the presence of UNSCR 1325, and how UNSCR 1325 is thought about. Chapters five and six explore the effects UNSCR 1325 and frameworks of "gender security" have upon advocacy work in Serbia. For the purposes of the present discussion, it is sufficient to be aware of how "gender security" is interpreted and praticed in relation to UNSCR 1325. UNSCR 1325 was intended primarily as a tool to gender mainstream security concerns, as evidenced by statements like 'recognising the urgent need to mainstream a gender perspective into peacekeeping operations'. ${ }^{163}$ However, the initial intention of UNSCR 1325 as a tool to simulate action within the UN system has not prevented innovative and creative rethinking of the resolution. In part, this is because embedded within the broader discursive terrain relating to UNSCR 1325 are specific notions of gender security. These notions of gender security are each ambiguous and incomplete and thus reliant upon contingent systems of meaning, generally related to the varying ontological logics reflecting individual/international approaches to security outlined in this section. Furthermore, it is because gender security is a performative discourse, momentarily fixed through a cluster of significations, opening a space for resignifications.

16. United Nations Security Council Resolution 1325 (UNSCR 1325) 31 October 2000: 8/RES/1325 (2000). 
Understanding gender security as a performative discourse which can be (re)signified, (re)articulated and (re)presented highlight how discourses are utilised in specific ways for political purposes.

\section{CONCLUSIONS.}

Thinking about the concept of "security" requires consideration of several questions: 'Security from what? Security by whom? Security achieved through what means?', and 'security for whom?'164 This chapter has sought to make explicit the ontological construction of debates about the configuration of security. Through delineating the ontological assumptions underpinning state-centric security discourse, it is apparent that focussing the referent object upon the state (re)produces a concern for the structure of the international system, which is almost certainly chaotic, and a belief that the contours of state behaviour are shaped by human nature: with this vision, militarization is inevitable unless controlled. The riposte to state-centric security visions has been the individual-centric security visions, which, through the conceptualisations of Critical and Human security, aims to transform the way that security is comprehended, noticing different violences. Much of the gender security discourse touched upon in this study reflects individual/international assumptions of security. In constructing and presenting a particular security discourse, activists draw upon conscious and subconscious significations clustering around security discourse. As will be made clear in the following chapter, the gender politics of activists affects the specific and particular configuration of security. The nuances of "security" are best uncovered through an understanding of security as a performative discourse, as this conceptualisation reveals the political contingency at the heart of the ontology of gender security.

Undertaking an ontological critique of the security studies literature deconstructs the logics arranging and ordering the functioning of security discourse. Gender forms a crucial part of these logics of security, whether it is explicit, as in the critical, individual notions aiming to address gendered insecurities, or implicit, such as in the masculinist logics embedded within state-centric perspectives upon security. The discourse of security is unfixed and momentarily fixed, and those moments of partial fixation are dependant upon significations, which can be altered through resignification. This framework provides a useful entry point into the issues dealt with in this thesis as it recognises that some feminist security perspectives are constructed in response to the perceived need to intervene into the "dominant" militarised security discourse. The notion of signification reappears in chapter four, where significations of security made by feminist and women's activists in Serbia during 2008

${ }_{164}$ P. H. Liotta 'Boomerang Effect: The convergence of National and Human Security' Security Dialogue Vol. 33, No. 4 (2002), pp. 474 - 475 outlines the first three questions. Hoogensen and S. V. Rottem 'Gender Identity and the Subject of Security' Secwrity Dialogwe Vol. 35, No. 2 (2004), p. 156 insist upon the fourth question. 
are deconstructed to highlight the influences of the post war context in making and undoing a discourse of gender security. Unpacking the significations that cluster around security is a necessary analytical element for the articulation and representation of a discourse. ${ }^{165}$ Recognising the performative nature of gender security discourses makes explicit the role of historical contexts in signifying security. This chapter has sought to expose the way(s) in which significations that cluster around the performance of security discourse profoundly affects the organisational logics of security.

165 Laclau and Mouffe Hegemony and Sociulist Sirategy, p. 113. 


\section{CHAPTER THREE.}

\section{PICKING THE PETALS: PROFILING GENDER POLITICS.}

Towards the end of an interview, drinking a final gulp of strong and sweet Turkish coffee, I ask Zibija Dh-Šarenkapić, the coordinator of DAMAD, a feminist human rights organisation in Novi Pazar, if there is anything else to mention. Pointing to the large fabric flower brooch that $I$ am wearing that day, Zibija tells me that 'feminism must not return again to dogmatic frames: it has to respect every part of that flower'.' The flower brooch looks like a rose in full bloom, made up of several fabric petals, with each layer of petals gtadually forming a tight mass in the middle. Zibija indicates that each petal within the flower represents different gendered, feminist and female principles, and somewhere, one of those petals is the contribution of women from her NGO in Novi Pazar. The feminist and women's movement in Serbia incorporates diverse and wide-ranging political positions influencing interpretations of gender security discourse. Any configuration of gender security is interwoven with a particular set of gender politics. In this study, gender politics refers to the stances taken towards feminism, hopes for the future and perspectives about the past and present. This chapter pays attention to the profile of gender politics amongst activists of feminist and women's NGOs in Serbia.

Feminism, as a theoretical approach, social movement, and academic school of thought, incorporates a wide range of epistemologies, ontologies, and practices that cooperate, merge, or conflict with each other. In Serbia, this feminist diversity is multiplied and complicated by the numerous transitions Serbian politics and society has faced in the past twenty years, including state socialism, war, and democratic transition. These transitions continue to reverberate today, forming the backdrop to feminist and women's organising in Serbia since the late 1970s. Undertaking a comprehensive historical narrative of feminist and women's organising in the region since 1978 is not the objective of this chapter: hence many groups and issues are not explicitly discussed. ${ }^{2}$ The structure of this chapter is neither precisely chronological nor specifically thematic. While the discussion of the transitions shaping Serbian feminist and women's organising is chronological, the narrative diverts its attention

\footnotetext{
1 Interview, Zibija Dh-Sarenkapić, coordinator of DAMAD, Novi Pazar, 19 July 2008.

2 For example, there are feminist and women's groups focussing on particular groups facing specific forms of discrimination; such as $l z$ Krnga, a women's disability rights group, Lesbian rights organisations such as Labyris and Novi Sad Lesbian Organisation (NI.O) and Roma women's rights groups. These groups carry out very important work targeting specific social problums women face in Serbia, but to discuss their work in any depth is far beyond the bounds of this thesis. Interviews were conducted with some activists of these organisations to enable the researcher to have a better sense of the context and frameworks that operate within women's and feminist organising in Serbia.
} 
to explore how these experiences have affected the gender politics of individuals and/or groups. The position and profile that feminist and women's organisations in Serbia adopt affects their perception of gender security discourse. Investigating the impact of these transitions upon the profile of gender politics in Serbia highlights the effects of personal-political imaginations about war and conflict upon feminist and women's organising.

To outline how personal-political imaginations of war, conflict and post-conflict in Serbia have significantly shaped the profile of gender politics in Serbia, this chapter discusses the impact of several moments of transition. The first section explores the growth of autonomous feminist organising during communist Yugoslavia, providing a historical context for a particular stream of feminist activism and philosophy in Serbia. In the second section, the impact of war upon feminist and women's organising in Serbia is investigated. I argue that the diversity and divisions within feminist and women's organisations in Serbia have been affected by personal and/or public perspectives towards the role of the Serbian state in relation to the war crimes committed during the 1990s. The final section focuses upon the impacts of the democratic changes at the start of the twenty-first century. I demonstrate that perceptions about the role of Serbian state in relation to the war crimes committed during the 1990s has shaped the frameworks affecting the political stances adapted by contemporary feminist and women's groups in Serbia. Through a semi-chronological thematic overview of the development of Serbian feminist and women's organising, the factors affecting the political profile of the groups will be explored, outlining the gender politics of activists. It is clear that the negotiation of personal-political imaginations about conflict and post-conflict affect the constitution of gender politics in Serbia

\section{FEMINISM AND COMMUNISM}

Exploring the effects of the Yugoslavian Communist experience upon feminist organising in Serbia reveals the context and roots shaping contemporary feminism and feminist philosophy in the region. This section initially highlights the claims of state socialism to have resolved the "Women Problem". One long-term consequence of the claim to have resolved the "Women Problem" has been a negative social attitude towards feminist equality aims in post-communist Central and Eastern Europe. Attention then moves to understanding the growth of Yugoslav feminist and women's organising during the 1980s. The unique form of communism that developed in Yugoslavia allowed a space for a clearly theorised form of feminism to emerge, spawning a type of feminist activism with strong links to some groups today. Contemporary gender politics in Serbia has been influenced by the experiences and memories of feminist organising in Yugoslavia: most notably as a claimed - or 
perceived - foundation for the existence of autonomous feminist organising that is critical of the state. As will be discussed later in this chapter, these historical perceptions of what constitutes feminist activity shape contemporary social and political attitudes towards feminism in Serbia.

\section{Communist Practice and Women's Rights.}

The tangled relationship between women's rights and Marxist theory means that state socialist governments made limited attempts to consider women's rights. Marx and Engels argued bourgeois man used women as a means of production, preventing true equality for women. ${ }^{3}$ Thus, emancipation from capitalist structures would allow women to escape 'open or disguised domestic enslavement'. ${ }^{4}$ Communism as a universal theory meant emancipation of the workers applied to everyone, including women. There was no need for a specific feminist theory: female oppression would be resolved when all are emancipated from capitalist structures. This complicates the relationship between women's rights and Marxism, since Marxist theory 'takes for granted' that under socialism women would have full equality with men in public and economic life. ${ }^{5}$ As a consequence, when attempts were made to apply Marxism in practice, early leaders were inadequately prepared to deal with issues relating to women, particularly issues about sexuality, reproduction, the sexual division of labour, or patriarchalism. ${ }^{6}$ However, because of the role Yugoslav women had played in the Second World War, where the Anti-fascist Front of Women played a crucial role in the liberation of Yugoslavia, Communists in Yugoslavia were forced to redouble efforts to ingratiate themselves with women and to appeal to them with what amounted to one type of feminist thinking.7 Despite the lack of theoretical subtlety regarding women's rights, specific attempts were made by Communist governments to address women's issues.

Communist governments in the Soviet bloc and Yugoslavia gave women a wide range of legally enshrined rights regarding employment and status in political life. Official Soviet and Yugoslav ideology stated that the "Women Problem" faced by capitalist societies had been solved with socialism. ${ }^{8}$ A 1985 report on 'The Role of Women in the Development of Socialist Self-Managing

\footnotetext{
${ }^{3} \mathrm{~K}$. Marx and F. Engels, The Communist Manifesto (Oxford World Classics, Oxford, 1998) pp. 22 - 23.

4First quotation; ibid., p. 22, second quotation; F. Engels, cited in M. Buckley, Women in the Soviet Union' Feminist Reriew No. 8, (1981), p. 79.

'Buckley, Women in the Soviet Union', p. 17.

'A.G. Meyer 'Feminism, Socialism, and Nationalism in Eastern Europe' in Women, Stute, and Party it Easterm Europe (eds.) S. L. Wolchick and A. G. Meyer (Durham, 1985), p. 19.

'S. Slapsak 'Between the Vampire Husband and the Mortal Lover: A Narrative for Feminism in Yugoslavia' in Reseunth on Russia und Eastem Eumpe, Vol. 2,(1996) pp. 215.

B. Jancar, 'The New Feminism in Yugoslavia' in P. Ramet Yugarlania in the 1980s (Boulder, Colorado, 1985) pP. 201 - 203.
} 
Yugoslavia' presented to the UN by the Socialist Republic of Yugoslavia was clear in its insistence that,

'The social problems of women, problems linked to their work, family and children of all communities, are most frequently considered, analysed, solutions proposed and efforts for their implementation exerted in the organisation of the Socialist Alliance'?

The claim made here is that the "Women Problem" has been internally resolved within Yugoslav Socialist institutions and structures, and so there was no need to establish specific bodies to address any problems faced by women. Commentators including Barbara Einhorn and Maxine Molyneux have conceded that state socialism's wish for women's emancipation was genuine, pointing out that women's emancipation was an 'integral part of the wider goals of socialist states'.10 Despite official state support for female emancipation as a means of achieving economic and social development goals, women endured a very different reality.

Although women under communism had a range of legal rights, patriarchal structures were left unchallenged. As a result, women carried out 'heavy jobs in the paid labour force, and housework made more difficult with little to buy, inadequate household equipment, or... few support services."11 Dubbed the "double shift" by many academics, women 'shoulder[ed] paid employment, housework and political/community responsibilities.'12 Put simply, there was more for women to do, in both public and private spheres. Communist theory did not look at the family and the private sphere, and its concentration upon public life meant patriarchy within the private sphere remained unchallenged. Furthermore, women's emancipation was forced since communist ideology expected women to participate in public life. ${ }^{13}$ The apparent contradictions between the promises of communist theory and its reality frustrated women across the Soviet bloc and Yugoslavia. However, socialist feminists, most notably Maxine Molyneux, have pointed out that the limitations of socialism for women's rights cannot 'all be ascribed to the failures of policy or theory'.14 While she acknowledges that women living under state socialism faced problems with the double shift, she also points out that socialist states have a 'superior record' on women's rights, for instance abortion and employment rights. ${ }^{15}$

\footnotetext{
The Role of Women in the Development of Socialist Self-Managing Yugoslavia: National Report of Yugoslavia on the Achievements in Promoting the Status and Role of Women during the UN Decade for Women (Belgrade, 1985), p. 26.

${ }^{10}$ B. Einhorn Cindenlla Goes To Market: Citizenship, Gender and Women's Movements in East Central Eumpe (london, 1993), p. 20 and M. Molyneux 'Socialist Socicties Old and New: Progress Towards Women's Emancipation?' in Feminist Revies, No. 8, (1981), p. 2.

It N. Funk and M. Müller et al 'Dossier on Women in Eastern Europe', in Sacial Text, No. 27 (1990), p. 89.

12 G. Masscy, K. Hahn, and D. Sekulić, Women, Men, and the "Second Shift" in Socialist Yugoslavia' in Gender and Sociefy, Vol. 9, No. 3 (1995), p. 364.

13 Funk and Müller et al 'Dossier on Women in Eastern Europe', p. 114.

14 Molyneuex 'Socialist Societies Old and New', p. 29.

15 Ibid., pp. 5 - 7.
} 
Rather, limitations arise from a deliberate policy where traditional patriarchy and the Communist system mutually reinforce each other as socialist states simultaneously promoted motherhood and full employment for economic reasons. Since it was a policy of state socialism to go down this route, state socialism did not "fail" to give women emancipation in the private sphere: rather there was no specific policy to challenge patriarchy.

The contradictory emancipation experienced by women during the period of state socialism has had negative consequences for how feminism is viewed across Eastern Europe. A strong 'anti-feminist' current dominates the region, in part due to forced emancipation. ${ }^{16}$ A Bulgarian women's NGO director claims that 'women do not care about women's issues' because 'after 45 years of "emancipation", women have had enough'.17 With the image of an emancipated women thrust upon them by socialist ideology, women were expected to work, frequently in low-paying, low-status jobs and to juggle the vast majority of family commitments, in addition to party obligations: leaving a sense that no-one really benefited from full employment.18 Furthermore, the ideology of state socialism 'dramatically modified' meanings of certain expressions frequently occurring in feminist ideas, such as emancipation, solidarity and equality. ${ }^{19}$ As a consequence, vocabulary common to western feminist ideas are viewed as 'descriptive terms appropriated by an authoritarian, repressive socialism, referring to the disturbing realities imposed by that system'.20 Additionally, while in the process of representing female emancipation as fait accompli, state socialist governments presented western feminist ideas as an unnecessary and dangerous ideology from the capitalist West. These factors combine to create a set of uneasy associations with "feminism" for many across Eastern Europe: creating tricky conditions for feminist organisations to convey their ideas. As will become clear later in this chapter, in Serbia, this social and political hostility toward feminism has been enhanced by the political stances and roles of resistance adopted by some feminist organisations in response to the events and consequences of war and nationalism.

\footnotetext{
16 'The literature on this is extensive. See A. Argent 'Hatching Feminisms: Czech Feminist Aspirations in the 1990s' Gender and History, Vol. 20, No. 1. (2008), pp. 86 - 104, N. Funk and M. Mueiler (ed.) Gender Politics and Part-Communism: Refletions from Easitem Fiumpe und the Former Sorver Union (Routledge, London, 1993), J. Acsady 'Urges and Obstacles: Chances for Feminism in Eastern Europe' in Women's Studies Intermutional Forum, Vol. 22, No, $4(1999)$ ), pp. 405 - 409 and L. Occhipinti 'Two Steps Back? Anti-feminism in Eastem Europe' Anthropology Toddoy, Vol. 12, No. 6 (1996), pp. $13-18$.

$17 \mathrm{~K}$. Ghodsee, 'Nongovernmental Ogres? How Feminist NGOs Undermine Women in Postsocialist Eastern Europe' in The Intemational

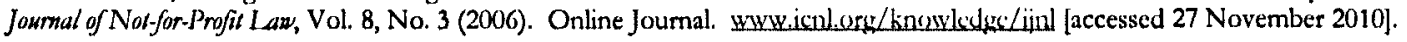

${ }^{18}$ Occhipinti 'Two Steps Back?' p. 16.

19 Acsady 'Urges and Obstacles', p. 405.

${ }^{20}$ Funk 'Introduction' N. Funk and M. Mueller (eds) Gender Potitics and Post-cammunism: Reflections from Eastem Europe and the Former Soniet Union (Routledge, London, 1993), p. 4.
} 


\section{The Yugoslavian difference.}

In 1992, the Croatian feminist journalist, Slavenka Drakulic, wrote of her frustration toward Western feminists reducing women in Eastern Europe 'to a common denominator'.21 Although there are socioeconomic commonalities, the experiences of women in Central and Eastern Europe should not be oversimplified, as different forms of communism, culture, attitudes towards women's bodies and variations of women's organisations exist/ed across the region.22 Many feminists in Serbia have similar aims of transformation and emancipation shared by some feminists worldwide: but activists operate within particular historical and contemporary contexts. Women in Yugoslavia lived in a different social, political and economic environment to women in Soviet bloc counties and the capitalist West. These different conditions had implications for the aims of emerging feminist organisations. Feminist organisations tend to develop in response to unique historical and/or contemporary circumstances, and divergences between the gendered opportunities a society claims to offer and reality.23 In Yugoslavia, feminist organisations partly developed in response to contradictions within Communism. As in the Soviet bloc, Yugoslav women also faced problems as a consequence of the double shift and forced emancipation, but Yugoslavia had systematic differences in ideology which affected feminist and women's organising. Yugoslavia broke away from the USSR in 1948, and was able to determine its own system of communism. This resulted in systematic differences that unwittingly encouraged the growth of feminist theory and activity in some parts of Yugoslavia much earlier than in the Soviet bloc.

Yugoslav communist theory shared an 'essential core' of Marxism with Soviet theory, but differed in several respects: for example, Yugoslavia criticised the policies of the USSR, and crucially, Yugoslav communism was highly decentralised. ${ }^{24}$ This was Yugoslavia's 'official ideology' of samoupravljanje: a system of self management and direct democracy exercised by each federation within Yugoslavia and more locally through workers councils. ${ }^{25}$ Samoupravljanje did not allow for autonomous groups separate from the state to exist, as all issues could be resolved within the system. As a consequence, officially, there was no need for consideration of women's issues outside the state apparatus. ${ }^{26}$.

\footnotetext{
${ }^{21}$ Drakulić, How We Survited Communism and Even Laughed, (Vintage, London, 1992), p.123

22 Funk 'Introduction' pp. 8 - 9, and T. Renne 'Disparaging Digression: Sisterhood in East-Central Europe' in Ana's Land. Sisterbood in Easiem Eumpe (Boulder, 1997), p. 3. There have been notable achievements by feminists to avoid generalisations about the effects of the communist experience across Yugoslavia and the Soviet bloc, including J. Lukić, J. Regulska, D. Zavirsek (eds) Women and Cikizenship in Centrul and Eastem Eumpe (Aldcrshot, 2006), Einhom Cinderella Goes To Markel and Cilizenship in an Enlurging Eumpe: From Dream to Awakening (Basingstoke, 2006).
}

${ }^{23}$ S. Peterson and A. S. Runyan, Global Gender Isswes (Westview Press, Boulder, 1999) p. 116.

24 F. W. Neal, Yugoslav Communist 'Theory' in American Slavic and East European Review, Vol. 19, No. 1 (1960), pp. 42 - 62.

${ }^{25}$ S. Zukin, Beyond Marx and Tila: Theory and Practice in Yugoslav Socialism (Cambridge University Press, Cambridge, 1975 ), pp 48 - 9.

26 The Role of Women in the Development of Socialist Self-Managing Yugoslavia: National Report of Yugoslavia on the Achievements in Promoting the Status and Role of Women during the UN Decade for Women (Belgrade, 1985), p. 26. 
However, because of Yugoslavia's more liberal form of communism, during the 1970s, a space for a 'tiny thread of civil society' was created. ${ }^{27}$ The opportunities offered by samoupravljanje means that the feminist movement in Yugoslavia has a longer "modern" history, as it was already established well before the collapse of Communism, as well as a greater connection to ideas and understandings first stated in the West'.28

Samoupravljanje was a form of communism admired by many worldwide, so Yugoslavia had good relationships with the capitalist West, Eastern Europe and less economically developed countries. The relative openness of this form of state socialism meant Yugoslavs were able to travel freely, compete for contracts all over the world, and requests for loans and aid were looked upon more favourably. ${ }^{29}$ The relatively open borders allowed new ideas, including feminism, to filter through from all over the world. Slavenka Drakulić, a Croatian feminist, talks of how during the 1970s and 1980s, travel and relatively open borders meant she was able to read western feminist literature, subscribe to the American feminist magazine, $M s$, and listen to feminists around the world visiting Yugoslavia talk in public about their ideas. ${ }^{30}$ Yugoslavia's system of communism allowed a slither of intellectual exchange (not freedom), enabling western feminist theory to trickle through. However, this intellectual exchange should not be overplayed, as the political circumstances in Yugoslavia meant that Western ideas had a limited effect both in terms of the emerging ideas of feminisms during communism and in the growth of feminism in the region during a period of war and intense nationalism.

A perceived key 'turning point' for feminism in Yugoslavia was October 1978. ${ }^{31}$ An international conference, followed by an informal Yugoslav gathering - the first public, autonomous feminist meeting in Yugoslavia - was held in Belgrade. Titled Drug-ca žena. Žensko pitanje - novi pristop? (Comrade Women. The Women Question- A New Approach?), the conference gathered together feminists from across Europe alongside feminists from Zagreb, Belgrade and Sarajevo. ${ }^{32}$ The

${ }^{27}$ A. Milić, Nationalism and Sexism: Eastern Europe in Transition', in (eds) R. Caplan and J. Feffer Europe's New Nationalism: States and Minorities in Conflict (Oxford University Press, Oxford, 1996), p. 178.

${ }^{28}$ Renne 'Disparaging Digression: Sisterhood in East-Central Europe' p. 3.

29 M. Glenny, The Balkans 180t - 1999: Nationalism, War and The Greal Powers (Granta Books, London, 2000) p. 570.

30 Interview Salvenka Drakulić, printed in Funk and Müller et al Dossier on Women in Eastem Europe', p. 109.

31 Interview, Lepa Mladjenović, Coordinator: Autonomous Women's Centre, Belgrade, 27 March 2008.

32 Interview Salvenka Drakulić, in Funk and Müller et al 'Dossicr on Women in Eastern Lurope', p. 109, L. Vušković, S. Trivunac 'Feministička grupa Zena i Društvo' (Teminist Group Women and Society) in Ka Vidljitoj Zenskoj Istoriji: Zenski poknet $n$ Beogradn 90-ib (Towards a Women's I-listory: The Women's Movement in Belgrade in the 1990s) (ed.) M. Blagojević (Centar Za Zenske Studije, Berograde, 1998), pp. 27 -60. It should be stressed that the "arca" that the Yugoslav feminists came from was much wider. The invited speakers who are listed in this particular record may have lived in the major cultural and intellectual urban areas of Yugoslavia, but many of the participants and gencral public came from all over the then country. 
international conference saw three days of speakers, film screenings, debates and informal conversations, guided by a focus on themes including feminist and women's organising, the effects of socialism upon women, sexuality, identity and culture. ${ }^{33}$ The international context and presence was important in legitimising and publicising the dissident voices articulated by the Yugoslav feminists, ensuring extensive media coverage. ${ }^{34}$ The conference was a defining moment for publicising and throwing together a group of people curious about feminist ideas. ${ }^{35}$ Thirty years on, the conference is recalled by both former participants and young feminist activists as a 'foundational event' for feminist history and genealogy in the region. ${ }^{36}$ Although the issues faced by women have changed since 1978, many feminist activists discussed in chapter five of this thesis locate their roots within the feminist ideas emerging from this conference.

The key focus of the conference discussions was 'the assessment that Yugoslavs generally do not see that there is a women's problem in their country and that self-management had failed to liberate women'37. Yugoslav feminists spoke from a very particular communist of samoupravljanje, where women had many legal rights granted to them by the state. Žarana Papić, one of the organisers, argued that 'even though many things have been achieved' by state socialism, inequalities are 'still present', ${ }^{38}$ Papic highlights the need for communist theory to account for patriarchy, pointing out that patriarchy 'represents an anachronism and is not in accord with the progressive tendencies of self-managing society'.39 In this statement, Papic attempts to negotiate the difficulties in formulating internal critiques of samoupravljanje: the official statement that the "Women Question" was adequately addressed by the state, along with strong state controls and tight censorship made it difficult for feminists in Yugoslavia to criticise the state. Despite attempts temper criticisms of the state, feminism in Yugoslavia during the 1970s and 1980s was 'seen as a four-letter word', and a 'danger' to communist Yugoslavia because it was a foreign ideology 'imported into the country' from the West.40

\footnotetext{
${ }^{33}$ C.Bonfiglioli 'Belgrade 1978: Remembering the Conference Drug-ca zena. Žensko pitanje - nori pristop thirty years after' Unpublished dissertation, Utrecht University (August 2008), p. 86.

${ }^{4}$ Ibid.

35 Ibid.

36 Ibid, p. 26.

37 Jancar 'The New Feminism in Yugoslavia' p. 209. It should be emphasized that there were divergences between the Marxist critiques by "western" feminists at the time, and the very specific critiques of state socialism articulated by Yugoslav feminists. Key Western feminist speakers included Diana Leonard-Barker (UK) and Christine Delphy (France), who were at the time working on feminist reformulations of Marxism. See, for example, Christine Delphy The Muin Enemy: A Mastrialist Anatysis of Women's Oppression (trans. D. Leonard-Barker) Explorations in Feminism, No. 3 (Women's Research and Resources Centre Publications, London, 1977).

34 Preparatory papers and letters for the organization of Drug-ca žena. Žensko pitanje - novi pristop? Žarana Papić's papers, Belgrade Women's Studies and Gender Research Centre (Belgrade), facsimile rcproduction in Bonfiglioli 'Belgrade 1978: Remembering the Conference' Unpublished dissertation, Utrecht University (August 2008), pp. $125-130$.

${ }^{39} \mathrm{Ibid}$

40 Drakulić, How We Survied Communism and Even Laughed p. 132.
} 
Some Yugoslav feminists organising in Zagreb at the end of the 1970s 'received threatening letters... got divorced, were accused of neglecting their families', spat at in public and burgled.41 In Serbia, feminists in Belgrade were required to meet 'almost secretly' throughout the 1970s. ${ }^{42}$

Despite these difficulties, in 1979, the first feminist group in Yugoslavia not attached to the communist government, Žena $i$ drustvo (Women and Society), ${ }^{43}$ was formed in Zagreb, now the capital of Croatia. 44 In 1980, Women and Society was established in Belgrade. 45 Throughout the 1980s, the group met on an ad-hoc basis to theoretically discuss women's issues. ${ }^{46}$ A speaker would introduce a theme for that day's deliberations, or there would be a film screening, ${ }^{47}$ Discussions honed in on a wide assortment of issues relating to patriarchy and socialism. ${ }^{48}$ While these discussions were mainly theoretical, Women and Society was important in the establishment of activist feminism in Belgrade because it was the first time that there was autonomous public discussion about women's issues. ${ }^{49}$ Towards the end of the 1980s some participants from Belgrade Women and Society took steps towards establishing a telephone hotline to support female victims of violence, launching SOS Hotline on International Women's Day, 8 March 1990.50 Over the course of the past twenty years, many towns and cities in Serbia have established a similar helpline: some of the organisations informing this study operate SOS Hotlines. ${ }^{51}$ The telephone helpline is staffed almost entirely by volunteers who are trained to support victims of violence in dealing with their personal traumas. SOS Hotline is one of the few organisations established before the wars of the 1990 s which continues in Serbia today.

\footnotetext{
41 Ibid., p. 129.

42 Slapsak 'Between the Vampire Husband and Mortal Lover' p. 218.

${ }^{43}$ The first time that a group's name is mentioned, the name will be given in Serbian and English. The second and consecutive times will be in English. Some groups (e.g. SOS Hotline) are known by their English names.

44 Intcrview Salvenka Drakulic,, in Funk and Müller et al 'Dossier on Women in Eastem Europe', p. 109.

45 Vušković and Trivunac 'Feministička grupa Žena i Društvo', pp. 47 - 9.

46 Interview, Bojan Alexsov, Former Women in Black Activist, London, 22 January 2008.

47 Interview, Iepa Mladjenović, Coordinator: Autonomous Women's Centrc, Bclgrade, 27 March 2008.

48 Vušković and Trivunac 'Feministička grupa Žena i Društvo', pp. 51 - 55.

49 Interview, Ispa Mladjenović, Coordinator: Autonomous Women's Centre, Belgrade, 27 March 2008.
}

so Z. Mršević 'Belgrade's SOS Hotline for Women and Children Victims of Violence: A report' in S. Gal and G. Kligman (cds.) Reproducing Gender. Polidics, Publis, and Eirerydry I jfe after Sacialism (Princeton University Press, Princeton, 2000), p. 371, I. Mladjenović and V. Litrican (Translated 'T. Renne) 'Belgrade Feminists 1992: Separation, Guilt and Identity Crisis' in Feminist Review, No. 45 (1993), p. 114, Limail correspondence (conducted for my own MA dissertation, Sheffield, 2006) with VL, 15 September 2006.

31 See Appendix B NGO Interests and Relationships. All groups who are part of the AŽC (Autonomous Women's Centre) network operate an SOS Hotline. 
The rise of feminism in Yugoslavia during the late 1970s and the 1980s 'bought the skeleton out of the closet', publicly highlighting issues and concerns resulting from the limitations of the claimed emancipation of state socialism. ${ }^{52}$ The development of autonomous groups provided a space for 'an embryonic feminist movement' developed by urban intellectuals with access to western feminist ideas, questioning the 'assumption that the struggle for the equality of women was synonymous with class struggle..53 Through challenging the perception that state socialism benefited women, Yugoslav feminists engaged in a process of feminist theorising and activism prior to the collapse of state socialism. ${ }^{54}$ These ideas about feminism, elaborated at the 1978 Drug-ca žena conference, and Women and Society during the 1980s, form part of the intellectual heritage and genealogy for a particular stream of feminism that developed during the $1990 \mathrm{~s}$. Almost simultaneously with the collapse of communism, Yugoslavia was thrown into war, and nationalism became a key and pressing issue upon the political agenda. The new realities surrounding war meant that some feminists from SOS Hotline and Women and Society, alongside new activists, were crucial in shaping ideas about pacifism and political responsibility that moulded contemporary feminist ideas in Serbia.

\section{POLITICS, WAR AND INTERESTS}

During the course of 1990 and early 1991, the short period between the collapse of state socialism and the outbreak of war in Yugoslavia saw a mushrooming of feminist and women's groups in Belgrade. The majority of these groups, which no longer exist, were concerned with inclusion of women in the political process and ensuring gender equality within Serbian society. ${ }^{5}$. As the disintegration of Yugoslavia escalated into conflict over the course of summer 1991, women's and feminist organisations responding to the war and its consequences were established. This section will argue that conflict was more than simply the impetus for the growth of feminist and women's organising: more significantly, attitudes and perceptions towards conflict and the consequences of conflict had - and continue to have - a significant impact on the political profile of organisations in Serbia. First, attention will be paid to the coalition of groups insisting that a critical attitude towards war and its consequences is a crucial element of their feminist philosophy. This particular political attitude about feminism can be traced back to the proliferation of pacifist feminist groups in the early

\footnotetext{
s2 Jancar, "The New Feminism in Yugoslavia', p. 219.

33 Milić, 'Nationalism and Sexism' p. 178 and M. Korač, Women organizing against Ethnic Nationalism and War in the Post-Yugoslav States', in W. Giles et al, Feminists Under Fine: Exchanges acrass War Zones (Between The Lines, Toronto, 2003), p. 28.

54 L. Mladjenovic "The Politics of Knowledge of Difference: Thoughts and Contradictions in Feminist Politics in the Anti-war Movement in Belgrade from 1991 to $1999^{\prime}$ in Peaceworke, March 2000.

35 Notable groups include The Women's Lobby (est. 8 March 1990), Women's party/ZEST (est. November 1990) and the Women's Parliament (est. 8 March 1991). Sce C. Cockbum 'A Women's Political Party for Yugoslavia: Introduction to the Serbian Feminist Manifesto' Feminist Review No. 39 (1991), pp. 155 - 160 and Mladjenović and Litricin 'Bclgrade Feminists 1992: Separation, Guilt and Idencity Crisis', pp. $113-119$.
} 
1990s. Building on this, attention will then move to a discussion of the political/non-political division claimed by several activists during interviews. These political/non-political divisions are connected to attitudes about the conflicts of the 1990s, and have contributed to perceptions of "feminism" within both society and the NGO sector. These political positions form a significant kernel of what is described as gender politics throughout this thesis.

\section{Feminism and War: Coalitions.}

Much of civil society in Serbia was built against a backdrop of war and nationalism, a context that, for some, made it easier because "when something is so strong and explicit, then it is only your responsibility which is enough or a basic empathy... some kind of shame, pain or whatever... in a war surrounding you have many triggers from which to start thinking,'56 War triggered much feminist and women's activism in Serbia, and raised the profile of feminist peace activism. The most famous and vocal feminist-pacifist voice in Serbia is that of Žene $u$ crnom - Beograd (Women in Black Belgrade), which is the group at the centre of analysis in chapter five of this thesis. The group is part of a transnational peace network acting as 'a means of mobilization and a formula for action' on feminism, peace and peaceful protest. ${ }^{57}$ The Women in Black network originated in Israel in 1988, where Israeli women held weekly vigils in public places to protest against the Israeli occupation of the Gaza Strip.58 Each local group has their own vision and agenda, shaped through the historical context of the area, and contemporary political, social and economic circumstances faced by activists. In the case of Belgrade Women in Black, its formation during the midst of a nationalist civil war meant activists sought to express their understandings of the gendered mechanisms behind war and nationalism, subsequently shaping the aims and activities of the group.

Belgrade Women in Black was founded on 9 October 1991, shortly after hostilities between Serbia and Croatia escalated.59 Staša Zajović, one of the founding coordinators, made the 'firm decision' that a feminist-pacifist group was needed after experiencing the patriarchal structures and attitudes of other anti-war initiatives in Belgrade. ${ }^{00}$ Activists undertake nonviolent protest to oppose war, war politics, and nationalism, believing the state should accept political responsibility for the war crimes

\footnotetext{
5o Interview, Slavica Stonjanovic, Dircetor of Reconstruction Women's Fund, Belgrade, 31 March 2008.

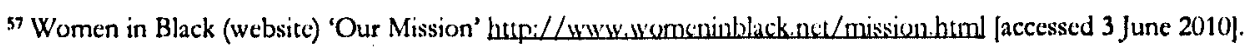

58 Ibid.

59 Women in Black (leaflet) June 1992 "Femmes en Noir" Contre La Guerre' (Women in Black: Against the War) in Compilation of information on crimes of uar against somen in ex-Yugostavia Women Living Under Muslin Laws (Montpellier, France, 1994 ), p. 55.

${ }^{60} \mathrm{~S}$. Zajović, cited in Women in Black, Women for Peace, (Bclgrade, 1994), p. 121.
} 
committed in the name of "Serbia".61 During the wars, weekly silent vigils, supported by a group of women wearing black, were held every Wednesday afternoon in Belgrade's main square. ${ }^{62}$ Protests during this period had two distinct strands. First; women protested against war and the consequences of war: rapes, ethnic cleansing, death and violence.63 Furthermore; activists protested against the Serbian regime, opposing intense nationalism as the 'motivating force' behind the wars. ${ }^{64}$ After the wars in Croatia and Bosnia-Herzegovina had officially ended in 1995, Women in Black responded to the dramatically increasing political violence in Kosovo, protesting against ethnic cleansing and increasing regime oppression accompanying political tensions. ${ }^{65}$ Visible, public protest continued throughout the "postwar" period, with the exception of the period of NATO bombing in 1999, where any street actions that did not support the regime were banned. ${ }^{66}$ After the fall of Miloševic in October 2000, protests continued to demand social justice and human rights, emphasising opposition to nationalism, war and the consequences of war, alongside demands for the Serbian state to take responsibility for its role in the war crimes committed in the 1990 s.

The actions and analysis of the gendered intrigues of war, militarism and nationalism are not solely down to Women in Black, as there were several feminist initiatives that sprung up during the early 1990s 'linked by an overlapping membership and a shared feminist, antinationalist and antimilitarist politics'.67 A key centre for gendered analysis of war and its consequences was Centar za ženske styduje Beograd (Belgrade's Women's Studies and Gender Research Centre), which was formally established on 8 March 1992.68 The centre offers university-level courses and lectures on a wide range of issues in feminism and gender studies.69 Initially conceived as an NGO project, independent of any political structure and autonomous in its work', the centre became part of the University of Belgrade in 2000 , when the directors of Women's Studies developed a long-term strategy of institutionalising

\footnotetext{
${ }^{61}$ lbid.

\$2 Women in Black (website) 'Women's Feminist-Antimilitarist Peace Organisation' hutpi//wwiviesncucromumurp/ [accessed 3 June 2010].

${ }^{63}$ Women in Black (Leaflet) "'Fcmmes en Noir" Contre La Guerre' (Women in Black: Against the War) in Compilation of information on crimes of war against women in ex-Yugarlatia, p. 55.

64 D. Hughes, Women in Black Against War in Yugoslavia' Eeministal An Online Journal of Feminist Construction, Vol. 3, No. 1, Lupi//www.feminista.com/archicucs/v3n1/hughes,heml [accessed 23 December 2005. No longer available].
}

os Women in Black (Website) We are Still on the Streets: Our 15 years' retrieved from hutp:/wwwiacncucrnom, oro/ [accessed 3 December 2007. The webpage has since been updated and the original is no longer available].

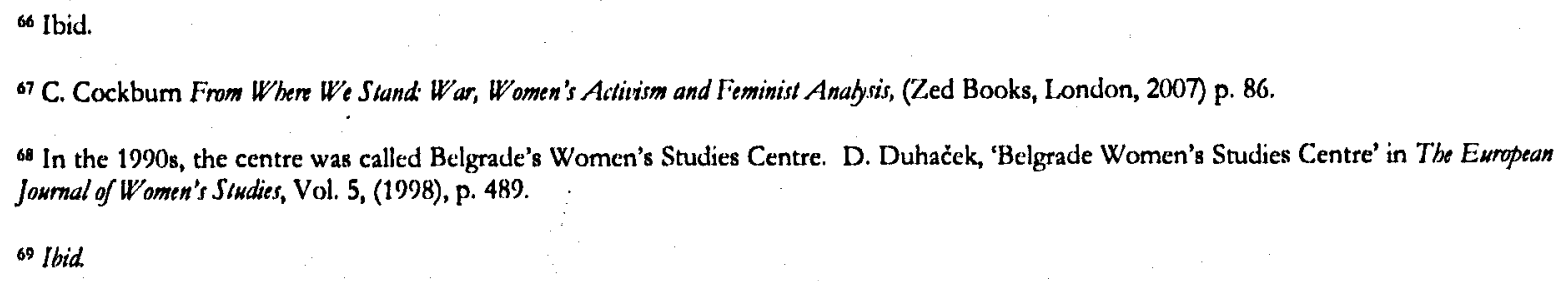


the centre. ${ }^{70}$ With an explicit and clear feminist stance, the centre frequently connects together theory and activism. Indeed, one of the founders, Sonja Drljević felt that 'feminism needs theory; Women's Studies can be a back up, something like a "recruitment" centre for feminism'.7" For several activists, the Women's Studies Centre was, and remains, an important source of feminist education and means of encouraging, nourishing or supporting integration into activist feminist networks. ${ }^{72}$

Some students who had studied at the Women's Studies Centre made their first forays into direct activism through volunteering at SOS Hotline. ${ }^{73}$ During the course of the $1990 \mathrm{~s}$, many SOS Hotline activists wanted to do more activist work. Inspired by a two week visit to women's organisations in Switzerland, Lepa Mladjenović established Autonomni ženski centar (Autonomous Women's Centre, $A Z ̌ C)$ in $1993 .{ }^{74}$ Initially established as a response to the consequences of war, the centre aimed to 'organise support to women raped in war, and to women who experienced male assault, wartime violence and refugees'.75 During the early 1990s, the centre struggled with the tension between the counsellor's neutrality and personal political commitment. ${ }^{76}$ A precarious position was settled on: an explicit antimilitarist and antinationalist stance while ensuring AŽC supported all women, collaborating where necessary with the institutions of the very government many volunteers were criticising. ${ }^{77}$ After 2000, AŽC restructured its activities into two main groups: one group focused on education and lobbying to facilitate institution-building, while the other group concentrated upon further developing the counselling and support provided for women. ${ }^{78}$ AŽC incorporates a wide range of feminist positions because the multiple aims and objectives of the centre mean different kinds of feminist approaches are needed. ${ }^{79}$ On the one hand, those who want to change the state institutions 'cannot be totally radical... [and] must have some position with mainstream language', and those who support the women need to be open for all women, and 'cannot have an explicit politics

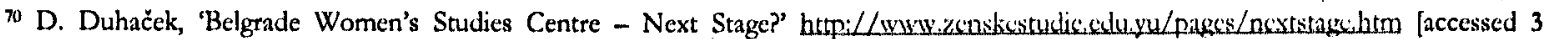
August 2007. No longer available. The Centre for Women's Studies is now at hrtp://2sinsisitudisisdurs/ [accessed 3 June 2010]]

${ }^{71}$ S. Drljević, cited in Duhaček, 'Belgrade Women's Studies Centre', p. 489.

72 Interviews: Marija Gajicki, coordinator, VIVISECT, Novi Sad, 13 May 2008, Slavica Stonjanović, Director of Reconstruction Women's Fund, Belgrade, 31 March 2008 and Diana Miladnović, Legal Advisor, Autonomous Women's Centre, Belgrade, 11 March 2008.

73 Ibid.

74 Interview, Lepa Mladjenović, Coordinator, Autonomous Women's Centre, Belgrade, 27 March 2008.

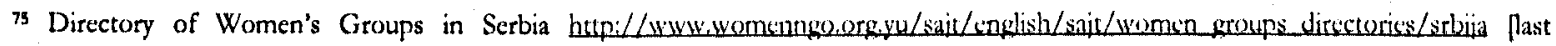
accessed 16 June 2006: no longer available]

${ }^{76}$ L. Mladjenović 'Women's Emotions and State Policies: A Women's Organisation Against Male Violence from a Counsellor's Perspective' paper given at the intemational conference 'Stop Domestic Violence against Women: Ten years of Austrian Anti-Violence Legislation in the Intemational Context', Vienna, November 5-6 2007, p. 2.

7 Ibid.

78 Ibid.

${ }^{79}$ Interview, Lepa Mladjenović, Coordinator, Autonomous Women's Centre, Belgrade, 27 March 2008.
} 
like Women in Black' because of the need to help all clients regardless of her personal political attitudes. ${ }^{80}$ The occasional difficulty in negotiating political stances is reflective of the range of gender politics that exist within feminist and women's organisations in Serbia.

A critical feminist attitude towards war and war politics underpins much of the work of Women in Black, AŽC and the Women's Studies Centre. With some other Belgrade-based groups - Incest Trauma Centre (established 1994), ASTRA Anti-Sex Trafficking Centre (established. 2000), Reconstruction Women's Fund (a local, independent donor organisation established in 2004) - an informal feminist coalition was created in 2007.81 The feminist coalition is linked by a shared critical attitude towards war and the consequences of war. ${ }^{82}$ The groups share a similar set of values based around a

'critical attitude towards institutions... these six groups have remained critical in the same way they were during the 1990 s. The groups are characterized by their independent attitudes, which are ceaselessly maintained and vocalised. We have strict and clear attitudes towards the war, facing the past, (political) responsibility... we completely support pro-European politics, and we clearly fight against homophobia, social injustice against all crucial economic and social problems... we from this circle were, from the very beginning, aware of the social necessity of this event [Kosovo independence]'.83

These values which are shared by all the groups in the coalition form the foundation of their cooperation and communication. Informal meetings allow for exchange of information and ideas about possible future activities, and decisions to be made about how they will support each other's campaigns. ${ }^{84}$ As a coalition, they share information and resources to support the production of joint documents and reports, such as the Alternative Report to the CEDAW Committee published in March 2007, a critical assessment of how successful the Serbian state had been in implementing CEDAW. 85 Most of the groups established in the 1990s as a response to war and its consequences share similar foundational political beliefs about feminism which continues to tie them together. The gender politics connecting these groups is a perception of feminism which is explicitly political and understands gender as a structure shaping social, political and economic phenomena.

on Ibid.

11 S. Zajović, Alsayss Disobedient (Women in Black, Belgrade, 2007), p. 30 and interview, Slavica Stonjanović, Director of Reconstruction Women's Fund, Belgrade, 27 June 2008.

B2 Zajović, Alsugys Disabedient, p. 30.

3s Direct quotation from interview, Jelena Visnjić, Coordinator, Voice of Difference, Belgrade, 10 May 2008 (in Scrbian). Similar statements were also made in the interview with Slavica Stonjanović, Director of Reconstruction Women's Fund, Belgrade, 27 June 2008.

34 Interview, Slavica Stonjanović, Director of Reconstruction Women's Fund, Belgrade, 27 June 2008.

as B. Brankovic and M. Lukić 'Altemative Report to the CEDAW Committee' (Belgrade, 2007). CEDAW is the UN Convention on the Elimination of all forms of Discrimination Against Women. 
Many who became involved with the feminist movement during the 1990 s were motivated by peace activism: many of the leading voices within the contemporary feminist movement in Serbia initially emerged through these groups during the $1990 \mathrm{~s} .{ }^{86}$ The all-encompassing nature of a heavily militarised society meant many feminist activists shared an antinationalist and antimilitarist philosophy. The strong links made between feminism and pacifism developed during the $1990 \mathrm{~s}$ means that the attitudes of activists and or the group towards war and pacifism is an important marker in the profiling of women's and feminist groups in Serbia. As a consequence, several groups seek a disconnection from the politics of peace activism - a stance frequently resulting in a group rejecting the "feminist" label. In essence, the gender politics held by activists in Serbia is deeply interlinked with perspectives about war and nationalism.

\section{Feminism and War: Divisions}

SOS Hotline, a telephone hotline established in 1990, faced difficulties in negotiating political tensions related to war and feminism. The founding volunteers of SOS Hotline were self-declared feminists, but by the mid-1990s, there was growing unease about the publically feminist stance of the group, contributing to internal tensions eventually shifting the aims of the group away from explicit feminist politics. ${ }^{87}$ These political tensions continue today. A number of past and present SOS Hotline activists were interviewed during the course of research for this thesis. Some activists considered themselves connected to the so-called "political" stream of explicit feminism, while drawing a careful distinction between their political activities and their SOS activities. However, other SOS volunteers do not consider themselves to be politically engaged. Self-proclaimed associations with the labels "political" and "non-political" is a common theme shaping the contours of feminist and women's organising in Serbia. The use of "political" or "non-political" by activists describes a set of attitudes held by the individual or group towards Serbia's position in relation to the wars of the 1990s, and is tangled with the attitude adapted by activists and organisations towards feminism. These overlapping divisions concerning (a) how feminism is thought about, and (b) the "political" nature of the group, combine to shape the gender politics of the group. The profile negotiated by individual activists and/or organisations has been profoundly affected by past, present, and future attitudes towards war and its consequences. In short, war has affected the associations made with gender and feminism in Serbia.

\footnotetext{
${ }^{86}$ Interview, Adriana Zahavijevoić, Women in Black Activist, Belgrade, 10 April 2008. 
While the labels "political" and "non-political" seem puzzling (surely all activism is political?), in Serbia, these descriptions carry particular connotations. A former Women in Black activist informed me of a,

'big division between Women in Black and their supportive network of women's activists feminists - who are political and dealing with both life and death, war and peace, and everyday political issues on one side and women in other women's organisations who are not political and who are concerned with activities like sexual violence and so on's8

Political activists and organisations see themselves as dealing with, as one activist put it, "high politics... we deal with the critique of official politics and practice, by creating an alternative' ${ }^{89}$ The claim to be political is (frequently) connected to the belief that the only way to move forward is to face the past and accept political responsibility for recent war crimes. Those who describe themselves as political rarely shy away from the "feminist" label, generally openly describing themselves, or the group, as feminist. Non-political women's groups in Serbia refrain from publicly stating an organisational position about war or facing the past, emphasising that the group exists to provide emotional and physical support to individual women, or to challenge notions about gender violence.

The division between "political" and "non-political" is not clear-cut. In some cases, the profile is explicit: Belgrade Women in Black are firm and insistent in articulating their political beliefs. The split between political and non-political groups is not simply a division between antiwar, antimilitarist and antinationalist feminist organisations on one side, and groups primarily concerned with addressing gender, sexual and domestic violence on the other side. The overlapping and interlinked connections and membership between groups in Serbia mean that the divisions between political and non-political groups are not clear-cut. It is necessary to understand beliefs of key individual activists within a group. A feminist position may be voiced amongst some groups renouncing an association with the political label, but for others, the repudiation of feminism and political issues related to the war go hand-in-hand with each other. Additionally, many groups, especially those in smaller towns, combine both activities. These groups view their feminist anti-militarist activities (defined as political) and work related to domestic violence (supposedly a non-political issue) as 'somehow one wholeness'. ${ }^{90}$ Despite murky areas, there is a tangible link between attitudes towards feminism and stances towards political responsibility: but how far these perspectives are vocalised is dependant upon the circumstances and context surrounding the individual and the organisation.

\footnotetext{
Interview, BA, former women in Black Activist, London, 22 January 2008

89 Interview, Marija Perković, Women in Black Activist, Vbras, 21 March 2008.

of Interview, Sandglass Women's Group activists, Kruševac, 3 July 2008.
} 
Before probing into these labels further, a few caveats should be issued. First; it is important to note that those who underscore that their group is "non-political" do so for a wide range of reasons. As will be discussed later in this chapter, these non-political groups may not agree with the political responsibility agenda, or adapt the "non-political" terminology as a strategy for survival. Second; the distinctions "political" and "non-political" should not be perceived as a model, and certainly not as a clear binary division. Rather, the terms should be viewed as a heuristic device to enable us to investigate the varying levels of complexities making up the interests and orientations of women and feminist organisations in Serbia. Finally, the terms "political" and "non-political" are used as it is the vocabulary utilised by activists: it is not without its problems. The way that groups and organisations consider their activities is a highly politicised choice, even if individual activists and leaders are not aware of these choices and the implications emanating from their choices.

These proclaimed "political" and "non-political" associations overlap with perspectives towards feminism. The strong pacifist feminist movement with a history of criticising the state has meant that connections are made between feminism and opposition to the state. For some, opposition to the state is translated as being "anti-Serbian". The roots of the connection drawn between feminism and an "anti-Serbian" stance can be found in the highly charged atmosphere of the 1990s when nationalist abuse directed at Women in Black protesters was common. Passer-bys would shout statements like;

'You must be from Zagreb. None of your signs are written in the Cyrillic alphabet',

'You are the most horrible thing existing in this country',

'How would you feel if a Shiptar raped you? Then you wouldn't hold this "Albanian women are our sisters"'.91

The strength of feeling that Serbs and Serbia was, and continues to be, negatively portrayed in relation to the war crimes committed during the 1990s should not be dismissed. As discussed in the thesis introduction, debates about the role played by the Serbian state during the wars of the 1990s remain contentious. Groups such as Women in Black, who publically condemned the actions of the Milošević regime during the 1990s, and currently proclaim a need for political responsibility, are often accused of being "anti-Serbian" for taking this particular political position. In taking this position, a link between feminism and a "political" stance is subtly made.

\footnotetext{
97 'The Reactions of Passers-by to the Protest of The Women in Black' (1993) in Women in Black, Women for Peace, (Belgrade, 1994) p. 12, 'Reactions of Passers-by during our Protests. May 1997 - June 1998' in Women in Black, Women for Peace, (Belgrade, 1998), pp. 8 - 9. The official alphabet of Serbian is Cyrillic, while the official alphabet of Croatian is Latin. Most Serbs switch between the Cyrillic and Latin alphabets in daily life. Women in Black write banners in both Cyrillic and Latin alphabets (and some say that they are careful to ensure an equal balance between the two at protests). 'Shiptar' is used as an insult, generally referring to Albanians: the term is derived from the Albanian name for Albania, Shipieria. In this context, Shiptar refers to a Kosovan Albanian. Women in Black held a banner saying "Albanian women are our Sisters" during the late 1990 s as a show of solidarity with Kosovo Albanian women.
} 
Research by Ase Berit Gródeland during 2003-4 found 47\% of focus group participants in Serbia felt NGOs represented something negative, in part because NGOs were thought to be 'not sufficiently nationalist in their approach', 92 One participant commented that 'I heard some words that were spoken [on television]...something that seemed to me as directed against the Serbian people... [NGOs should] have more nationalism'.93 While Grǿdeland's research is not specific to feminist and women's NGOs, her findings are relevant to understanding a connection between the political profile adapted by an NGO and how "Serbian" the organisation is deemed to be. Building on this, a link can be made between perspectives towards feminism and the stance taken towards Serbia's role in relation to the war crimes of the 1990s: a link dominating public perceptions of feminist NGOs. Image 3.1 (below) is indicative of an extreme version of the perspective that to be feminist is to also be "anti-Serbian". The image depicts members of the Serbian nationalist revival group Obraz protesting during a Women in Black memorial service for those massacred at Srebrenica. Members of Obraz view the description of the events that took place in Srebrenica in July 1995 as fabricated or exaggerated. By insisting that Serbian state and society need to accept political responsibility for Srebrenica, and that it was a genocide committed by Bosnian Serb forces, Women in Black activists are accused of being "anti-Serbian". Since Women in Black - an explicitly feminist organisation - has been one of the strongest voices condemning the war crimes of the 1990s, including the genocide in Srebrenica, a link has been drawn between public perceptions of feminism and being "anti-Serbian". Furthermore, the association made between feminism, antimilitarist and antinationalist stances have been subtly encouraged by some feminists through an insistence that nationalism is not compatible with the inclusive aims of feminism. The effects of these discursive connections between feminism and antinationalism affect how activists vocalise perspectives towards feminism.

\footnotetext{
92 A. B. Gródcland 'Public Perceptions of Non-Governmental Organisations in Serbia, Bosnia \& Herzegovina and Macedonia' Communist and Post-Communist Studier, Vol. 39, No. 2 (2006), pp. 233 -4.

${ }^{93}$ Focus group participant, cited in Gródeland Public Perceptions of Non-Governmental Organisations in Serbia', p. 235.
} 


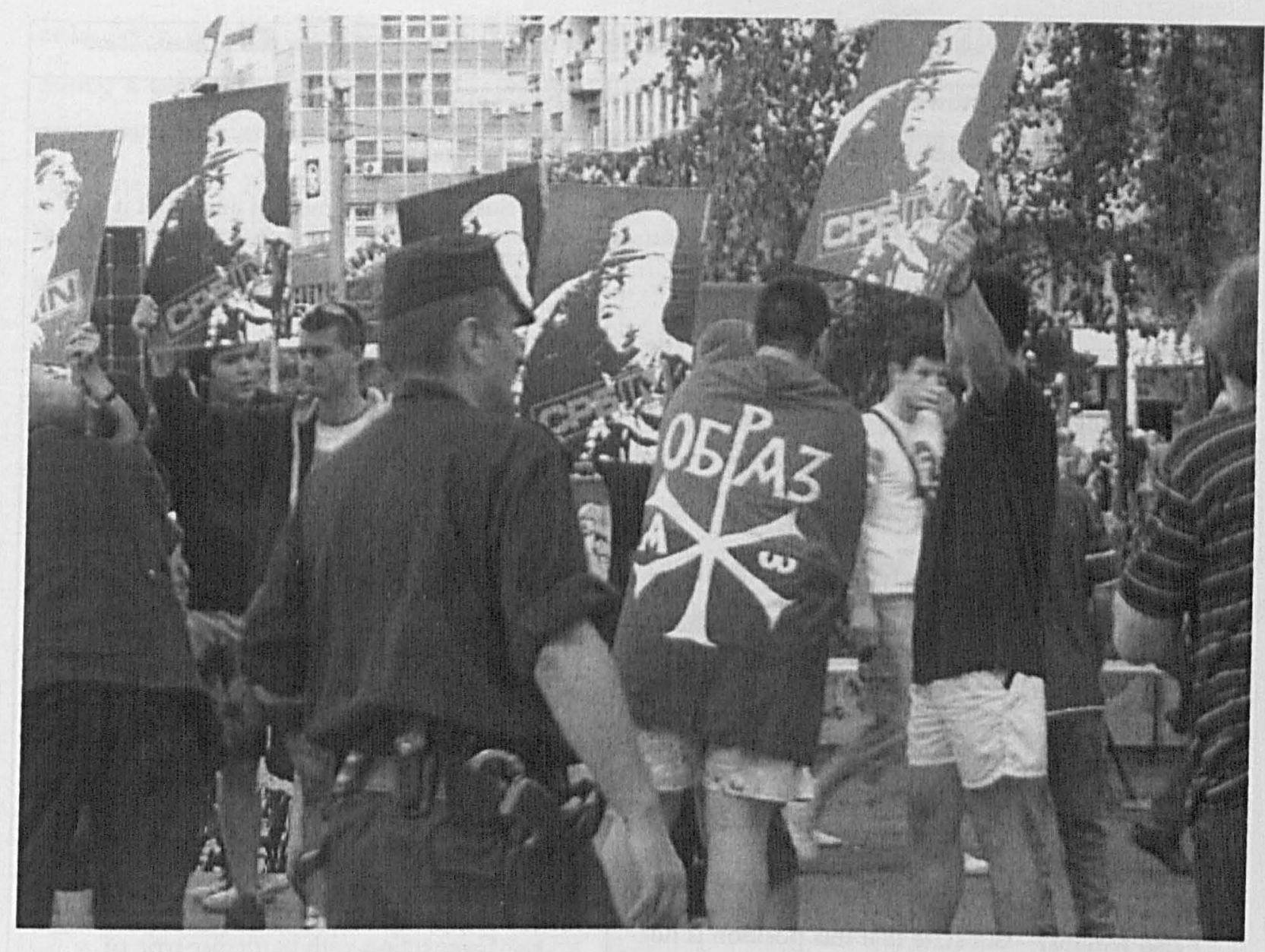

Image 3.1: July 10 2009. Members of Obraz protesting during a Women in Black memorial service held on the $14^{\text {th }}$ anniversary of the massacre at Srebrenica, Eastern Bosnia-Herzegovina. Abuse was directed at Women in Black activists, who were called 'iars' and 'witches' for condemning the crimes committed at Srebrenica. Photograph taken by Biliana Bibi Rakočević, 10 July 2009.

Attitudes towards feminism are articulated in multiple ways in Serbia. A 2004 quantitative survey of women's organisations by sociologist Andjelka Milić found that almost half (49\%) of activists defined themselves as feminists, while $47 \%$ were reluctant to identify themselves as feminists. ${ }^{94}$ Figure 3.1 (below), based upon interpretation of qualitative data gathered during 2008, deconstructs Milić's findings further. The table shows a huge range of stances, from a refusal to associate themselves or the group with feminism or feminist values, to those who express a complete, unproblematic association of themselves and the group with feminism. In between these extremes, there are alternative degrees of feminist principles: suspicious of the concept or wary of being associated with particular types of feminism, or insisting that, while individual activists are feminists, the organisation is not.

\footnotetext{
9. A. Milic 'The Women's Movement in Serbia and Montenegro at the turn of the Millennium: A Sociological Study of Women's Groups'
Feminist Revien, Vol. 76 (2004), p. 79.
} 


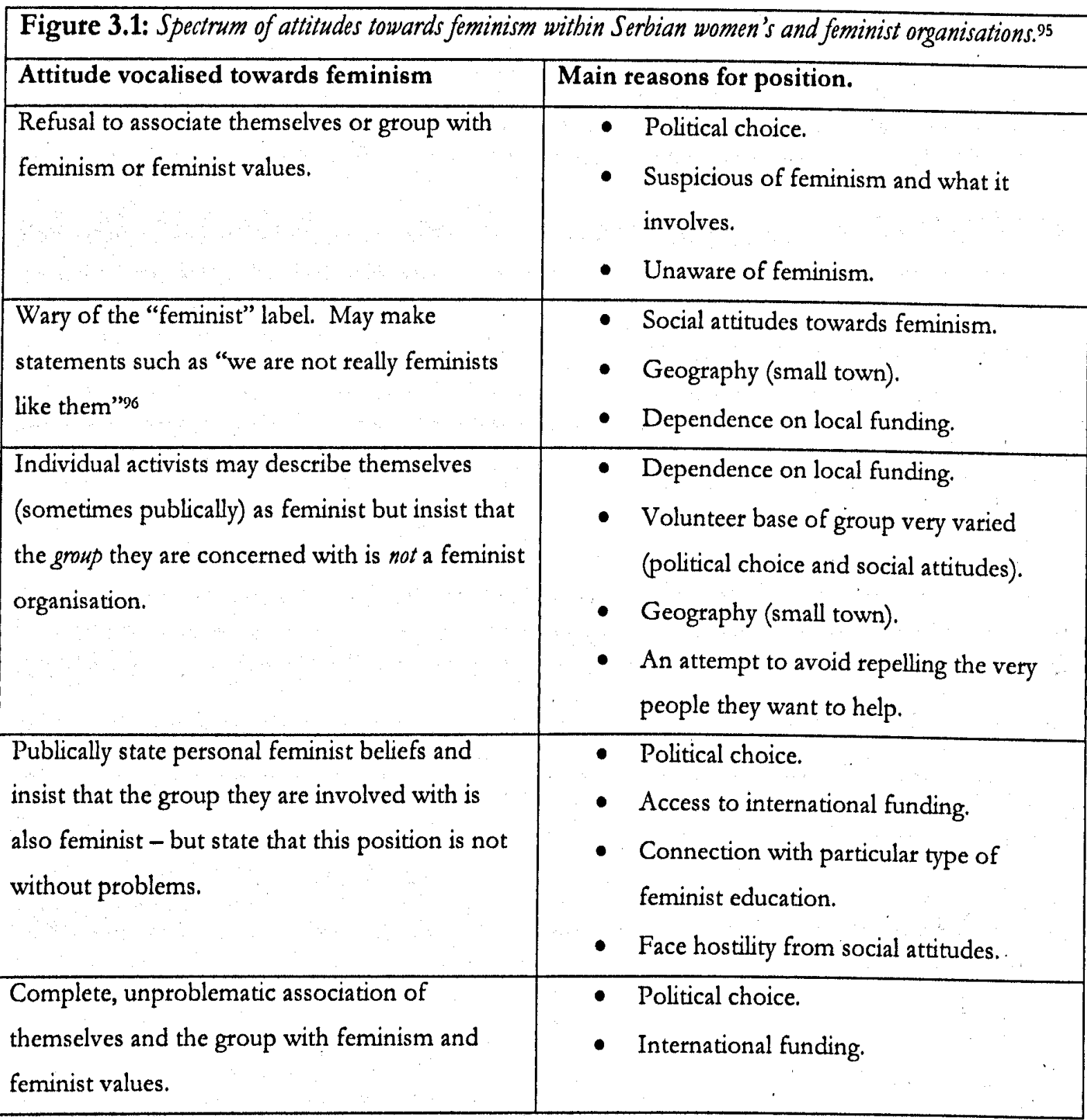

The refusal to associate themselves with feminism occurs for a range of personal, political and strategic reasons. Some organisations do not define themselves as feminist simply because activists do not see their work as about addressing or questioning gender relations, but rather, about providing humanitarian support to women. For instance, activists of the Women's Centre, Obrenovački, located in a town east of Belgrade, firmly insisted that they were not a feminist organisation, or even a women's organisation (despite being officially defined as a women's organisation): rather, the Centre aims to help anyone suffering violence. ${ }^{97}$ This position is influenced by social attitudes and context,

95 These classifications are based upon the researcher's qualitative field work findings: it should be stressed that this is not based upon any form of quantitative analysis.

${ }_{96}$ "Them" is never clearly articulated by groups taking this position but my own contextual knowlcdge suggests that "them" is Women in Black.

97 Interview, Activists of Women's Centre Obrenovački, Obrenovački, 16 April 2008. 
as hinted by activists of Zenska Alternativa (Women's Alternative) in Sombor, near the Croatian border, during a group discussion about their position in relation to feminism. Activists felt that gender problems stemmed from structural factors relating to patriarchy, but wanted to recognise this 'without aggressiveness'. ${ }^{98}$ For Women's Alternative, 'this aggressiveness is something that bothers us the most, that is why we are not feminists', and as a consequence, they preferred to call themselves a 'socialwomen's organisation'. 99 Additionally;

'Sombor is [a] quiet and slow town, to accept a feminist group [would be radical] and we adjust our activism... someone might consider us too quiet as activists and think that we should be more active, but we think that our approach is exactly the one that fits this town... we are well accepted here, but in Belgrade they consider us too mild'. ${ }^{100}$

The personal perception that feminism is an "aggressive" approach to tackling gender relations is juxtaposed with concerns about the best way of achieving the goals of the group within their environment. In essence, some organisations simply do not feel that "feminism" as a label is appropriate for their activities.

In some cases, activists vehemently refused to be associated with feminism, were suspicious of feminism, and viewed the "feminist" label in negative light. Many self-declared feminists feel that these negative attitudes arise out of a lack of theoretical understanding. Nevena Kostic, the coordinator of Zene za mir (Women for Peace), a feminist-pacifist group also operating an SOS Hotline in Leskovac (South-East Serbia), ran a workshop on feminism during 2003. Participants were asked to write on a piece of paper in two columns what they considered positive and negative concerning women's rights. ${ }^{101}$ Nevena pointed out that all the negative points were principles of patriarchal societies while the positive points concerning women's rights were feminist principles. ${ }^{102}$ Participants objected and 'said that they didn't understand feminism in that way. [Their response was that] "Everything is fine, except the word feminism!". ${ }^{103}$ Nevena felt that 'there is resistance to the word itself because there are such strong prejudices of what feminism is'. ${ }^{104}$ As has been argued, feminism in Serbia is frequently associated with support for the political responsibility project. One consequence of this association, as will be discussed further in the next section, is that some activists evade connecting themselves or the organisation with feminism for strategic reasons.

\footnotetext{
98 Interview, Žcnska Alternativa, Sombor, 20 May 2008.

${ }^{29}$ Ibid.

${ }^{100}$ Ibid.

${ }^{101}$ Intervicw, Nevena Kostić, Coordinator, Women for Peace, Leskovać, 1 July 2008.

to2 Ibid.

${ }^{103}$ Ibid.

104 Ibid.
} 
War made feminism in Serbia. Not only did the effects and consequences of war and conflict provide the impetus for the growth of feminist and women's organising in Serbia, but also, perceptions about war and its consequences shaped the political profile adapted by feminist and women's organisations. There is little doubt amongst activists that war and nationalism affected the profile of feminist organising in Serbia. ${ }^{105}$ The environment surrounding war and nationalism was a defining event that provoked a wide range of personal responses, almost inevitably affecting political attitudes. Slavica Stonjanović, an active feminist since 1992, saw the political environment in Serbia during the 1990 s like some kind of political test. You somehow shape or carve your political standing or you go and reshape it into something else'. 106 Political positions towards war and nationalism had - and continue to have - a significant impact in defining the profile of gender politics amongst feminist and women's NGOs in Serbia. Significantly, the dominant feminist voice in Serbia (Women in Black) places the political responsibility project, a socially contentious idea, high upon its agenda. As a consequence, some NGOs avoid association with "feminism" for strategic, practical or personal reasons. Responses, perceptions and attitudes towards Serbia's role in the conflicts of the 1990 s remains a key political force shaping the contours of feminists and women's organising in Serbia.

\section{THE WIND IN THE SAILS: DEMOCRATIC TRANSITION}

'The [democratic changes of 2000 was a kind of new initial power, it gave us a puff... like a wind... it pushed a wind into our sails: it encouraged us. It was a good time for a fresh start because the situation in the society was very fervent, the perspective of real social change was there, we could feel that things were changing'. ${ }^{107}$

Elections had been held throughout the 1990s where Milošević ensured that he was (illegitimately) elected. The Presidential elections of September 2000 once more saw a number of irregularities in counting the votes, culminating in the overthrow of Milošević in early October. Civil society groups were important in mobilising support to topple the regime, including feminists. During 1999, a group of feminists, including Slavica Stojanović and Žarana Papić, who were both already active with Women in Black and AŽC, started to organise Glas razlike (Voice of Difference) with the initial aim of engaging women in the upcoming elections. ${ }^{108}$ By 2000 , there were 650 volunteers all over Serbia participating in the Izadji i glasaj (Go and Vote) campaign, which went from door to door to mobilise

\footnotetext{
105 Interviews, Slavica Stonjanović, Coordinator, Reconstruction Women's Fund Belgrade, 27 June 2008, Adriana Zahavijevoić, Women in Black Activist, Belgrade, 10 April 2008, BA, former Women in Black activist, London, 22 January 2008 and Jelena Visnjić, Coordinator, Voice of Difference, Belgrade, 10 May 2008.

106 Interview, Slavica Stonjanovic, Coordinator, Reconstruction Women's Fund Beigrade, 27 June 2008.

107 Interview, lldiko Eredi, coordinator, ZIMG, Pancevo (Belgrade), 5 May 2008.

108 Interview, Slavica Stonjanović, Coordinator, Reconstruction Women's Fund Belgrade. 31 March 2008.
} 
the female vote. ${ }^{109}$ Several groups that were established in response to the Izadji i glasaj campaign continue today: such as VIVIsect in Novi Sad and Udruženje žena pešranik (Sandglass Women's Group) in Kruševac. 110 The democratic change of 2000 was a 'puff of wind, creating an environment encouraging the growth and networking of feminist and women's organisations all over Serbia.

However, the rapid growth of feminist and women's organising also destabilised the relative unity of the movement in Serbia. ${ }^{111}$ Schisms have been partially shaped by personal and organisational positioning in relation to the political responsibility project. I view the political responsibility project as one vision for the direction of Serbia's post-war reconstruction. This section explores how perspectives about the political responsibility project has shaped the context of contemporary feminist and women's organising in Serbia. Initially, this section will evaluate how the post-war political responsibility agenda has shaped the strategic positioning of some groups in Serbia. Attention will then turn to an examination of networks concerned with feminist-pacifism and domestic violence - selected because these networks are mentioned in chapters five and six - to highlight how the political responsibility project has affected the ideological coherence of feminist and women's organising in Serbia.

\section{Strategy and Political Responsibility}

As discussed in the thesis introduction, the role of the Serbian state and society in relation to the conflicts of the 1990s hangs like a spectre over the direction of democratic transition in the postconflict era. Political responsibility embodies a vision of what future post-war reconstruction looks like - or indeed, if post-war reconstruction is needed. Feminist and women's organisations locate themselves at a very specific juncture in these debates. These positions range from deliberately not engaging with political responsibility issues, in order to secure funding; to vocal statements made about the necessary of political responsibility, at the risk of their own security. The decision not to engage with political responsibility issues is as political as the choice to insist that Serbian society needs to face the past. Hence, attitudes about Serbia's role in relation to the conflicts of the 1990s, the problems of the post-conflict present, and hopes for future direction of post-war reconstruction are all political, whatever the stance and opinion taken. As a consequence, perspectives and responses towards the notion of political responsibility - whether made explicit or not - are viewed

\footnotetext{
109 Ibid.

110 Interview. Marija Gajicki, Novi Sad, 13 May 2008 and 'Udruženje žcna Peščanik' (Sandglass Women's Group) Information booklet (BiM Graf, Kruševac, August 2005), p. 8. (In Serbian).

'1' Interview, Dušica Popadić, Coordinator, Incest Trauma Centre, Belgrade, 28 July 2008. Sce also Incest Trauma Centre 'Announcement'

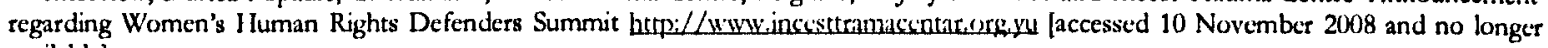
available].
} 
as manifestations of futures in the personal-political imaginations constituting the profile of gender politics held by individuals and organisations.

Elissa Helms found that women's groups in Bosnia-Herzegovina avoided being described as feminists for strategic reasons, drawing on gender essentialisms highlighting a caring and domestic role for women as a means of achieving their goals. ${ }^{112}$. However, in Serbia, shunning and evading associations with feminism can be for different strategic reasons. As discussed in the previous section, organisations who advance a concern with political responsibility - like Women in Black - are described as "political" groups, and tend to be unpopular: activists may face social disquiet at best, and violent abuse at worse. The extent to which a group associates with the political responsibility stance affects the membership of the group, the organisation's source of funding, and relationships the group cultivates with local government. For this reason, some activists and groups adapt a strategic position to balance, on the one hand, their personal concern with the responsibility agenda with, on the other hand, the interests and ambitions for the group. Evading a clear association with a "political" feminist stance - a stance frequently connected with the political responsibility project can be a strategic position adapted as a means of achieving the goals of the group.

Jovanka Brikić, the coordinator of Z̈ene $u$ Akciji, (Women in Action) a women's NGO in Velika Plana, a small town in central Serbia, has taken steps to ensure that activities related to political responsibility are not directly attributed to the group, so as not to alienate the other activists. ${ }^{113}$ This is particularly the case when workshops associated with Belgrade Women in Black and issues surrounding political responsibility are concerned:

'these gatherings [concerned with political responsibility] are not widely visited... even women who participate in our other activities do not respond to these. The women don't want to think about this subject and they think that all who are dealing with this issue ignore victims on the Serbian side... we must be very careful. We do not get into this debate too profoundly because we risk losing the chance of any collaboration with them. ${ }^{114}$

Too much association with the political responsibility agenda held by Women in Black endangers internal and external support for the group, and even their funding from the municipality. ${ }^{115}$ As a consequence, there is 'some kind of auto-censure' amongst the activists in the group who support the

\footnotetext{
112 E. Helms 'Gender Essentialisms and Women's Activism in Post-War Bosnia-Herzegovina' in Feminists Under Fin: Exchanges acmss War Zones (eds.) W. Giles, M. de Alwis, E. Klein and N. Silva (Between the Lines, Toronto, 2003).

"13 Interview, Jovanka Brikić; Coordinator, Women in Action, Velike Plana, 17 April 2008.

$114 \mathrm{lbid}$.

11 Ibid.
} 
political responsibility agenda, who ensure that they do not vocalise their anti-nationalist and anti-war perspectives too loudly at local level. ${ }^{116}$

Some groups sense that they are 'less sincerely supported' by the local government in relative comparison to other women's groups. For example, activists from Women in Action, working on domestic violence issues, were excluded from discussions regarding local social security strategy, even though other women's organisations in the municipality had been involved in shaping the strategy from the start. ${ }^{117}$ This echoes Áse Berit Gródeland's finding that $42 \%$ of civil society NGOs believed that local government has a negative attitude to NGOs, while only $26 \%$ of service-provision NGOs felt that local government is negatively predisposed to them. ${ }^{118}$ In the context of this chapter, civil society NGOs are the ones described as "political", and service-provision NGOs are groups focusing on humanitarian support. Conversely, groups who take an explicit political, feminist-pacifist stance, such as Women for Peace (Leskovac), choose not to ask for any support from local government because activists themselves do not support the politics of their local representatives.119 Certainly, 'before, and for some time after 2000, recognition, respect and cooperation between women's groups and local political bodies (or the authorities of the republic) was practically non-existent'.120 The fragile relationship between feminist organisations and local government has resulted in a decision taken by some groups to insist that they are just a women's organisation, and therefore to avoid an explicit association with the feminist political responsibility agenda. Alternatively, groups who choose to take a public stand on issues regarding political responsibility may prefer to assess the background of those in government before making a decision about working with them.

One reason that some groups evade association with the political responsibility agenda relates to funding concerns. Democratic transition saw a shift in funding opportunities: as opportunities to gain funding from the state or local government opened, many groups rejected or disassociated themselves from feminism - as it is perceived to be connected to the political responsibility project in a strategic move to protect their financial position. Part of the reason that some groups do not

\footnotetext{
116 Ibid.

117 Ibid.
}

118 A. B. Gródcland 'Suspiciously Supportive or Suspiciously Obstructive? - The Relationship Between Local Government and NGOs in Bosnia \& I Herzcgovina, Scrbia and Macedonia' Intemational Joumal of Pwbtic Admintistrution, Vol. 31, No. 8, pp. 224 - 34, 948.

119 Email correspondence with Jovana Dimitrijević, Activist, Women in Black; Belgrade and Women for Peace, Leskovac, 2 - 6 July 2009 . Until the 2008 elections, the Mayor of Leskovac was from the Serbian Radical Party, a nationalist party which insists that "Kosovo has been, is, will always be Serbian" and does not support co-operation with the Hague War Crimes tribunal. For this reason, activists chose not to ask for financial support from the local government.

${ }^{120}$ Milić 'The Women's Movement in Serbia and Montenegro at the turn of the Millennium' p. 75. 
declare themselves to be feminist is because they are dependent upon local government funding for survival and those making funding decisions are thought to not support certain feminist activities. ${ }^{121}$ Organisations are thought to have lost financial support from local government for their work on gender violence as a consequence of explicitly taking a feminist antimilitarist stance. ${ }^{122}$ However, many self-declared feminists indicated dissatisfaction or frustrations with the political compromises that some women's organisations make in order to get funding. ${ }^{123}$ Those groups, described as being donor driven, are thought to quash political attitudes challenging the position of the authorities, and are 'without any politics, without any values', placing their concerns with financial survival as a group. 124 The group's acceptance or evasion of the political responsibility agenda is perceived, by feminist and women's NGO leaders, to affect opportunities for funding, and in particular the level of funding accessed from state or local government.

The denial that their activities are political is a feature of women's organisations across Eastern Europe. ${ }^{125}$ However, within the Serbian context, the disassociation with issues perceived as belonging to a political domain is heavily tangled with individual and/or social positions in relationship to the wars of the 1990 s. In many cases, there is a conflation between "feminism" and "political responsibility", pinning publically unpopular associations onto "feminism". The negative perception of "feminism" means that it remains risky to publicly declare yourself as a feminist and many 'women's NGOs or some activists are not yet ready to fight this... at the moment you are attacked by the local community, the easiest way [out is] to say "we're working for women and we are not feminists"'.126 These tensions have become more apparent as the NGO sector has expanded since the democratic changes of 2000: some groups dissociating themselves from the political responsibility project are perceived to lack a commitment to feminist politics, policy or values, and their original intention and mission was watered down somewhat. ${ }^{127}$ Evading a clear association with feminism and issues surrounding political responsibility is a strategic move to ensure support from their local communities: a measure taken to ensure that volunteers, clients and donors are not alienated.

\footnotetext{
121 Interview, Lepa Mladjenović, Coordinator, Autonomous Women's Centre, Belgrade, 25 July 2008.

122 To clarify; while the perception that groups lost financial support as a consequence of their activities on political responsibility was very strong, no group told me specifically that they had lost funding as a consequence of their stance on political responsibility.

123 Most of the time, these kinds of statements were implicit rather than explicit. Two participants were explicit on the record: Dušica Popadić, Coordinator, Incest Trauma Centre, Belgrade, 28 July 2008 and Jelena Visnjić, Coordinator, Voice of Difference, Belgrade, 10 May 2008.

124 Quotation made off the record.

125 Einhorn Citizenship in an Enlarging Europe, pp. 61 - 93.

126 Interview, Dušica Popadić, Coordinator, Incest Trauma Centre, Belgrade, 28 July 2008.

127 Ibid.
} 


\section{Networks}

The huge variation in interests, attitudes towards feminism, and political values that make up gender politics in Serbia means that it is very difficult to talk of a single feminist "movement" in Serbia, if by movement, we mean that groups, organisations and activists work together for a similar set of goals. While not all feminist and women's organisations in Serbia share the same aims and objectives, some do, and there are networks of support that reflect this. In this section, networks relating to feministpacifism and domestic violence will be investigated to reveal how debates about the importance of political responsibility affect the ideological coherence of each network. Organisations had been informally networked throughout the 1990s, but with the democratic changes, space for the establishment of new groups and formal networks proliferated. The relative ideological coherence of the networks, and ways in which the networks function are connected to the profile of gender politics, is connected to how Serbia's past, present and future is envisaged.

The Women in Black network is strongly unified around the necessity of feminist-pacifism. The Women in Black network developed towards the end of the 1990s, when they were given funding by the German donor organisation, Heinrich Böll Stiftung, to finance a series of travelling workshops around Serbia.128 These travelling workshops formed a educational space for consideration of feminist ideas about power, democracy, civil society and antimilitarism. ${ }^{129}$ For these workshops, activists of Women in Black put together women with shared antimilitarist feminist interests, and enabled them to spend time talking to each other on issues critical for raising their consciousness. After a few workshops, women in those places started to organise their own groups. ${ }^{130}$ Subsequently, these groups came together to form the Women in Black Network: Serbia in 1997, sharing values of feminism and antimilitarism. The co-ordinator of the network, Staša Zajović, points to the importance of the democratic transition in 2000 for the growth of the Women in Black network, highlighting that fear, threats and oppression during the Milošević era meant that 'it was problematic for some women to even meet with us'. ${ }^{131}$ Certainly, the democratic changes after 2000 operied up opportunities for political interaction, enabling an effective network concerned with feminist-pacifism to be formed.

\footnotetext{
128 Interview, Zorica Trifunović, Women in Black activist, Belgrade, 15 April 2008. Sce also Zajović, Alwtys Disobedient, pp. $41-42$.

129 Zajović, Alurgys Disobedient, pp. $41-42$.

130 Interview, Ildiko Eredi, Coordinator, ZIMG, Pancevo (Belgrade), 5 May 2008.

131 Interview, Staša Zajović, Coordinator, Women in Black, Belgrade, 29 June 2008.
} 
The Women in Black network is made up of activists with a range of connections to other feminist or women's organisations and groups around Serbia. These connections include:

- Individual activists who act as representatives from that town. E.g. Marija Perkovic in Vrbas (Vojodina).

- A small group of self-declared Women in Black activists within an organisation not formally connected to Women in Black. E.g. Women in Action, Velike Plana.

- Groups who are connected to Women in Black. E.g. Women for Peace, Leskovac.

All activists are unified by a shared feminist-antimilitarist belief. While the network is not formally hierarchical, Women in Black in Belgrade acts 'like some kind of home group' at the centre, supporting all groups. ${ }^{132}$ Individual activists determine how $\mathrm{s} /$ he wants to be involved on each issue: from no involvement, to attending the seminars and workshops, to travelling to Belgrade for demonstrations and performances. 133 Each quarter, the network holds meetings (Image 3:2) to reflect and agree upon shared actions, initiatives, workshops and training sessions. ${ }^{134}$ The Women in Black network is unified by a set of shared political values regarding antimilitarism, feminism and political responsibility. This ensures a strong and clear mobilising structure based upon ideational factors, as will become apparent in chapter five.

The Women in Black network is ideologically coherent on the issue of political responsibility because this is central to the objectives of the groups involved in the network. As feminist-pacifists, activists have a keen interest in making sense of the explanations and processes that contribute to war, in order to prevent war in the future. For Women in Black activists, taking steps towards accepting political responsibility is necessary for future peace and reconciliation. In contrast, the network(s) of groups concerned about gender violence is much looser - not just because gender violence incorporates a broad range of issues - but because the gravitational force pulling together these groups is a concern with gender violence. That is, these groups are concerned with gender violence, as opposed to achievement of the political responsibility project, and so find different areas for collaboration. That said, some activists are concerned with both gender violence and political responsibility, and view the two issues as interrelated: as stated earlier, the divisions identified by feminist, political/non-feminist, non-political groups are not clear-cut. Image 3.3 (below, following

\footnotetext{
132 Quotation from Interview, Boban Stojanović, Coordinator, Queeria, Belgrade, 11 April 2008. See also Interview, Marija Perković, Women in Black activist, Vbras, (Belgrade), 21 March 2008.

${ }^{133}$ Interviews, Sandglass activists, Kruševac, 3 July 2008; Staša Zajović, Coordinator, Women in Black, Belgrade, 29 June 2008.

${ }^{134}$ Interviews, Staša Zajović, Coordinator, Women in Black, Belgrade, 29 June 2008; Miloš Urošević, Women in Black activist, Belgrade, 21 March 2008.
} 
Image 3.2) depicts activists concerned with feminist-pacifism and domestic violence participating in an International Women's Day parade in Belgrade in March 2010: indicative of the overlaps in group membership and interests.

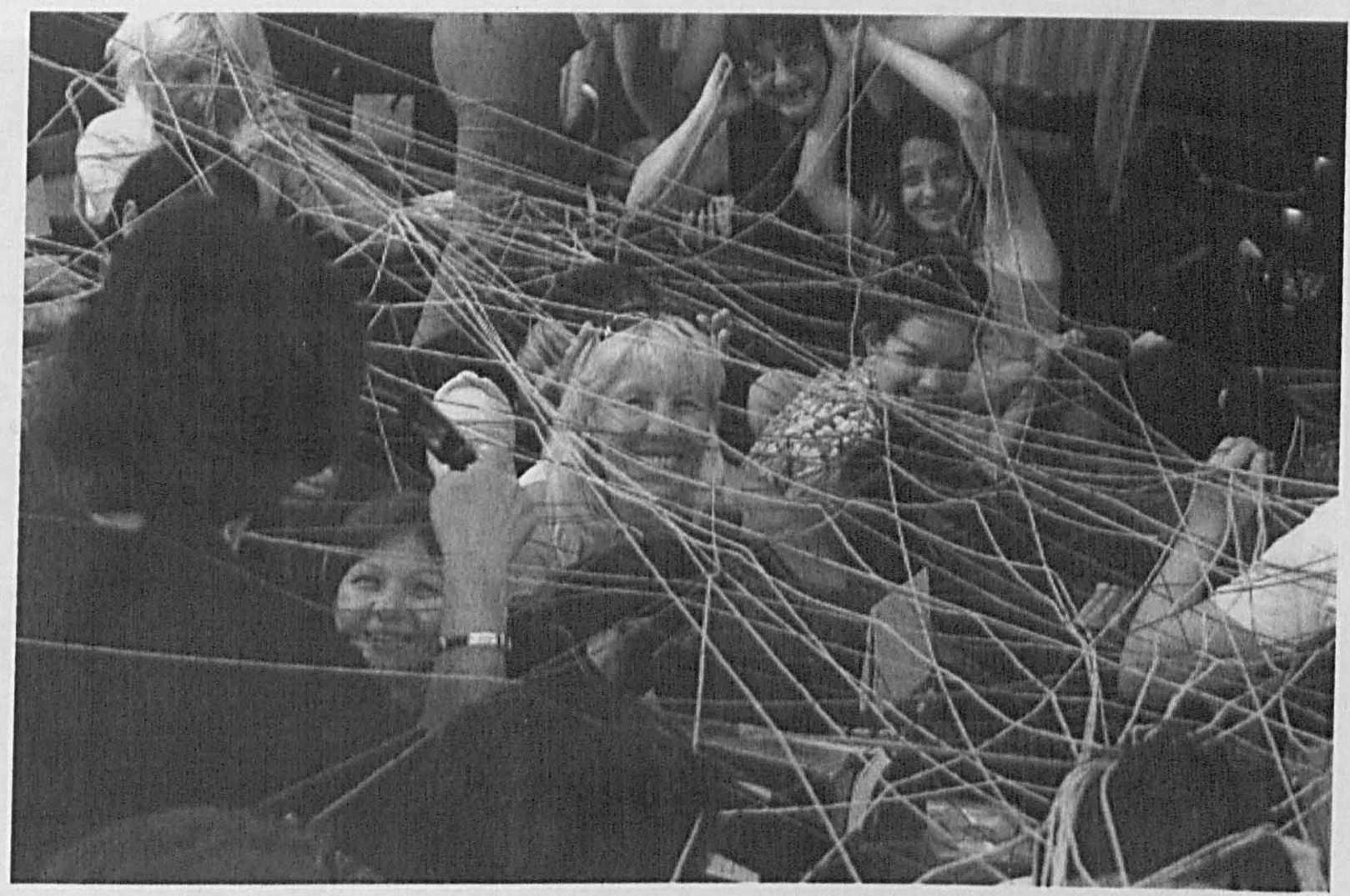

Image 3.2: Members of the Women in Black Network at a network meeting held in Kukaviča, near Leskovac June $5-7^{\text {th }} 2009$. The final activity at this meeting saw participants form a circle to weave a web with brightly-coloured balls of wool. The web symbolised the way that activists are connected through shared values and how the web (or network) is dependant upon all of them working together. Photograph taken by Biliana Bibi Rakočević, 7 June 2009.

The network(s) of groups concerned with gender violence is much looser: there is a much bigger group of actors with far more variance regarding political stances and attitudes towards feminism. Additionally, especially since 2000, domestic violence has become an issue which the Serbian government is concerned with. As a consequence, debates and actors relating to domestic violence are more institutionalised than in debates regarding feminist-pacifism. There are multiple networks and actors concerned with gender violence and a complex web of individuals, NGOs, national governance actors, and agents within international institutions working with specific issues relating to domestic violence. Activists working in relation to domestic violence are less ideologically unified as more political entry points exist: domestic violence is an issue that can incorporate a wider range of 
political positions in relation to the wars and attitudes towards feminism. Frequently, work is carried out in relation to specific issues or objectives relating to domestic violence - for example: coordinating social support services for victims of violence, training police officers in how to deal with domestic violence calls, or proposals for legal changes to the Criminal Code of Serbia - by bringing together a relevant group of actors and activists.

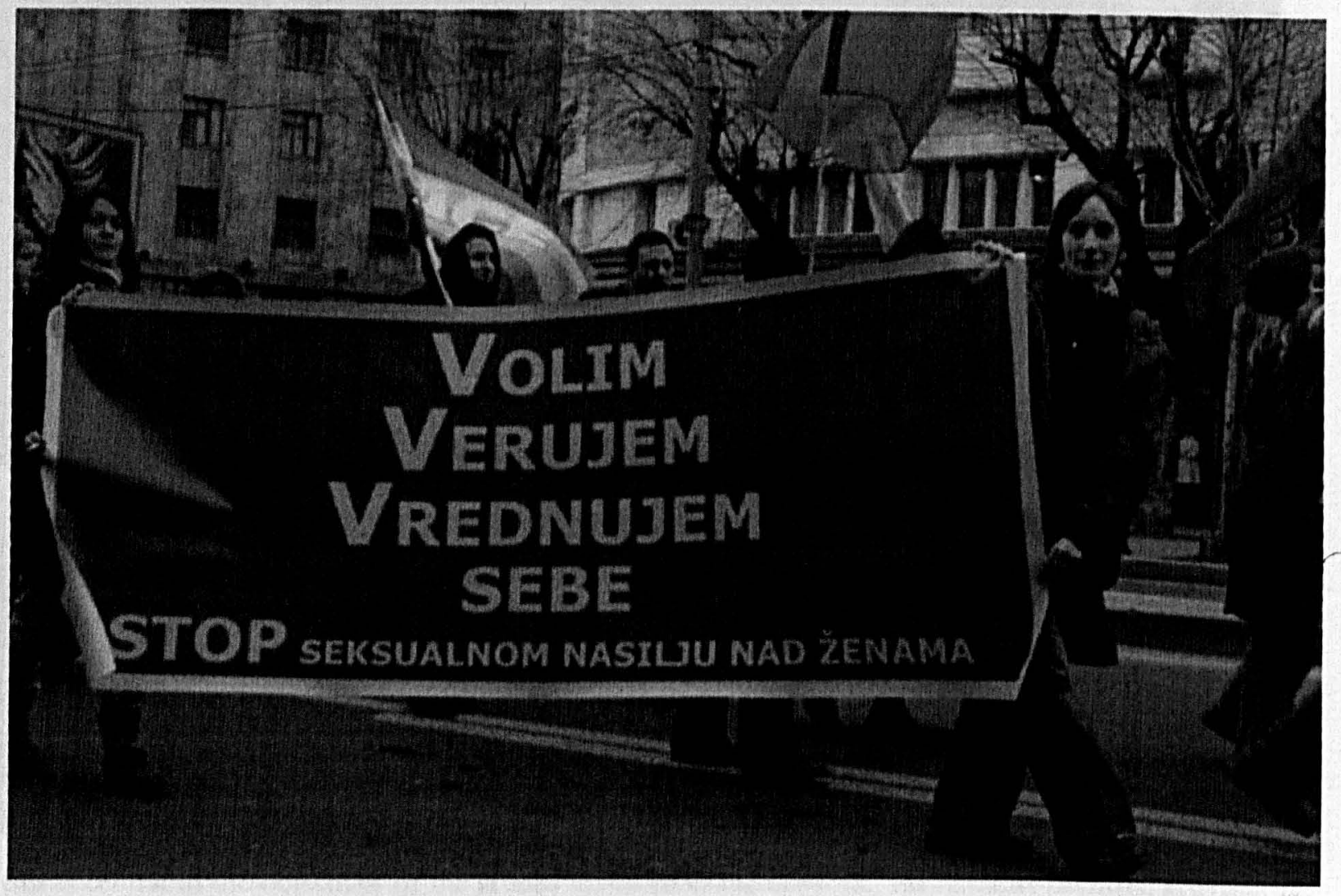

Image 3.3: Photograph taken during an International Women's Day parade, Belgrade, March 8 2010, where activists from a wide range of groups gathered together. Behind the red banner "I love, believe in and value myself: STOP sexual violence against women" held by activists primarily concerned with domestic violence issues, the rainbow flags held by feminist peace activists can be seen. This is typical of the overlaps and networks that exist within Serbian feminist and women's organising. Photograph taken by Biliana Bibi Rakočević, 8 March 2010.

The diverse range of political profiles and actors make it difficult to talk of a single network concerned with domestic violence, as will be apparent in chapter six. However, the most prominent network is connected to the AŽC in Belgrade, which has run seminars and training programmes for activists from feminist and women's NGOs around Serbia in feminist counselling since the late 1990s. ${ }^{135}$ While not all activists who have participated in the seminars and training programs have

135 L. Mladjenović ‘Autonomous Women's Centre Against Sexual Violence, Belgrade: A Personal Story' retrieved from http://www.womenngo.rs [accessed 16 June 2006]. See annual reports 2001 'Getting Stronger Opposing Violence'; 2002 'To Participate Actively and Together'; 2003/04 'Let's Coordinate the Action'; 2005 'Collaborate to Bring Change'; and 2007 'Spreading Promising Practices' for details of participants and format of these seminars. Retrieved from http://www.womenngo.rs on 10 July 2009. 
maintained a link with the AŽC in Belgrade, those who have are part of an informal network of 32 NGOs across Serbia providing services to women and children victims of violence. ${ }^{136}$ The network was established following a conference during September 2005: a meeting designed to enhance solidarity and to coordinate actions. ${ }^{137}$ Since its establishment, groups within the network have communicated with each other, exchanged knowledge, experiences and support, and coordinated campaigns for the international 16 Days of Activism Against Violence Against Women that is held each November. ${ }^{138}$ Although my analysis - in chapter six - of security discourse in relation to domestic violence does not have a specific focus on the AŽC and its policies, the organisation and its loose network has been, and remains, influential in shaping the contours of the domestic violence debate in Serbia.

The networks that surround the two feminist issue areas discussed in this thesis are not necessarily the clear entities that they might initially appear to be, due to the overlapping nature of feminist organising in Serbia. Some activists and groups working on domestic violence issues are also members of the Women in Black network, while other activists may refuse to be connected to Women in Black for a range of personal and/or political reasons. It is crucial to examine the political profile adapted by individuals as well as groups to make sense of the possible connections and interests that an activist and/or organisation have. These connections are being (re)forged in the post-war, post Milošević era: an era which sees a far more diverse range of political profiles and positions towards feminism being adapted by feminist and women's organisations in Serbia than during the Communist period or during the wars of the 1990s. Many activists feel that there has been an increasing fragmentation of the feminist and women's movement, which now has a far more diverse range of political positions in relation to issues surrounding war and nationalism, but conversely, the democratic changes since 2000 has also created the opportunity to connect and network with other groups who have similar interests.

\section{CONCLUSIONS.}

Feminism and women's organising in Serbia has changed since the 1970s, mostly in response to the political and social context that women live in. Yugoslavia's particular theory of socialist selfmanagement (samoupravljanje) allowed an intellectual space for the development of alternative ideas.

136 For example, activists from Women's Centre, Obrenovački attended a seminar in feminist counselling convened by the AŽZC in Belgrade, but have not maintained or developed links with AŽC. Interview, Women's Centre, Obrenovački, 16 April 2008.

${ }^{137}$ AŽC Annual report (2005) 'Collaborate to Bring Change', retrieved from Letpi//www.wumennewers on 10 July 2009.

${ }^{138}$ Interviews, Lepa Mladjenović, Belgrade, 27 March 2008, Jovanka Brikić, Velike Plana, 17 April 2008, Milica Simić, Bclgrade, 20 June 2008, Sandglass, Kruševac, 3 July 2008, Sibija Dh-Šarenkapić, Novi Pazar, 19 July 2008. Many activists who are outside of Belgrade expressed a wish that the AZZC network was more unified and carried out more activitics together as a formal network. 
This space meant that active feminists articulated and vocalised responses to the contradictions present within state socialism through the 1978 conference and Women and Society during the 1980s. The genealogical roots of modern feminism in Serbia can be traced back to these activities during the 1970s and 1980s, as many activists and participants played a part in the development of autonomous, activist feminist groups during the 1990s. As the collapse of Communism in Yugoslavia mutated into the disintegration of Yugoslavia, war and nationalism became an all-encompassing aspect of political life leaving its mark upon emerging civil society. Reactions to war, the consequences of war, and political violence in the region resulted in a multitude of groups who connected feminism with antimilitarism, antinationalism and the need for political responsibility. These values dominated the feminist scene during the 1990s: during a highly nationalised period when criticism of the state was politically and socially unpopular and at times, dangerous. As a consequence, feminism as an ideology and feminist activists were perceived to be connected with antinationalist and antimilitarist critiques insisting upon the need for political responsibility, resulting in some activists or groups to take a personal, strategic, and/or political decision not to be associated with feminism.

Investigating the impact of these transitions upon the profile of gender politics in Serbia highlights the effects of personal-political imaginations about war and conflict upon feminist and women's organising. The flower metaphor discussed at the start of this chapter, where the contributions of feminist and women's organisations in Serbia are envisaged as individual petals, is useful in illustrating that a vast range of gender politics that can exist. The plea made by Zbija for feminism to avoid returning to 'dogmatic frames: it has to respect every part of the flower' implies that there are schisms within Serbian feminist and women's organising. ${ }^{139}$ The growth of civil society made explicit the range of gender politics within feminist and women's organising. These gender politics relate to a range of perspectives about Serbia's conflict past, post-conflict present and future. This diversity means that the way that activists and groups discursively frame and employ "security" are different; since the way that the discourse of security is articulated, represented and utilised is product/productive of the political profile adapted. As we will see in the following chapter, the gender politics of activists and groups have impacted upon the specific logics of "security" adapted.

139 Interview, Zibija Dh-Šarenkapić, coordinator of DAMAD, Novi Pazar, 19 July 2008. 


\section{CHAPTER FOUR.}

\section{(RE)CONCEPTULISING SECURITY?}

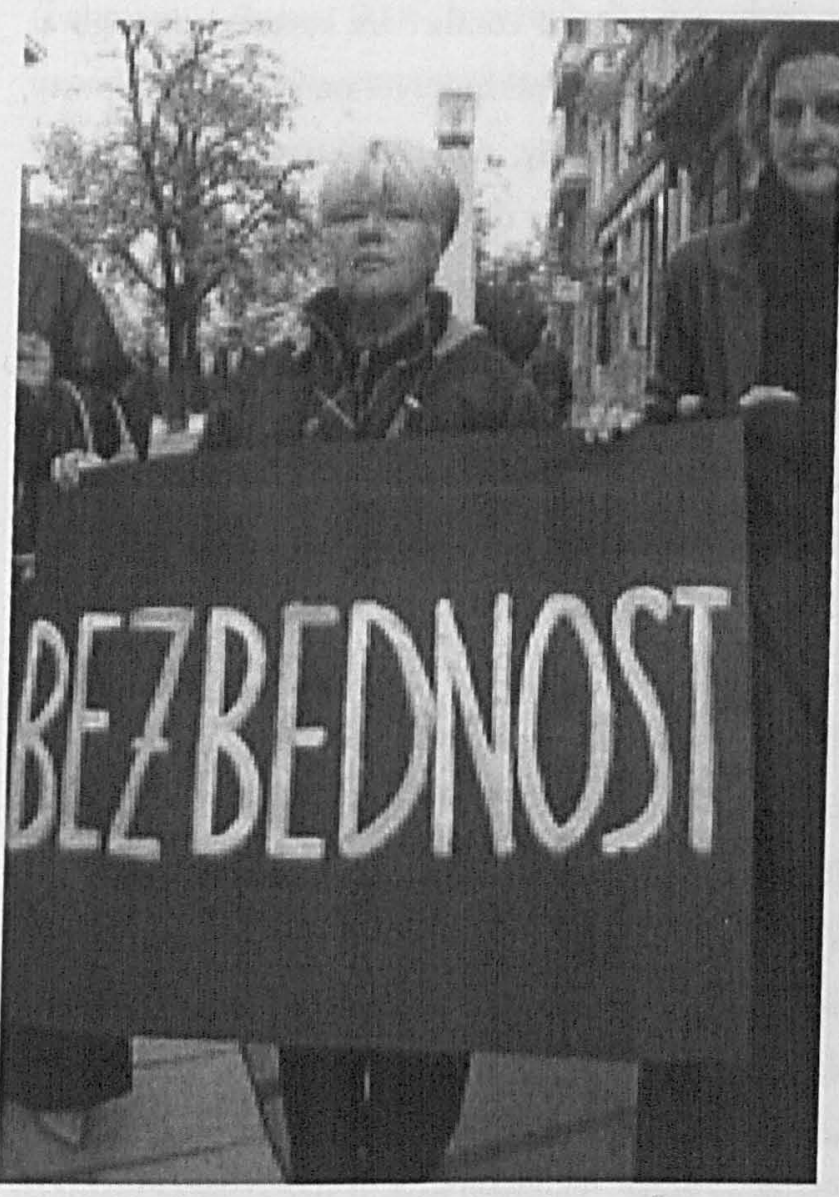

Image 4.1: Women in Black activist holding a banner marked 'Bezbednost (security) during a protest. Retrieved from http://www.zeneucrnom.org [accessed 1 May 2009].
The previous chapters established the context for understanding how configurations of gender security are shaped; first, by outlining the various logics of security discourse and second, by demonstrating the range of gender politics that exist within Serbian feminist and women's organisations. This chapter deploys a temporal discourse analysis strategy to illustrate how personal-political perspectives about conflict and post-conflict reconstruction affect specific configurations of gender security. By deconstructing the claimed and declared signifiers of security along temporal incisions, the politicalpersonal imaginations that constitute, limit and make possible visions of gender security are made explicit. That is, how security is thought about is wrapped up with perspectives and attitudes about the past conflicts, outlooks on the present postconflict problems and hopes for the future direction of post-conflict reconstruction. Image 4.1 (left) shows a Women in Black activist during a performance, holding a large black placard with a single word, beqbednost (security) written on it. This suggests that, with some activists and within some groups at least, energies are being devoted to issues around the concept of security, and that there is explicit activism related to "security". To fully understand the way that political values and identities have affected the delineation of security discourse, we need to take a step back and examine how "security" has (not) been explicitly signified. 
This chapter explores how personal-political perspectives relating to conflict and post-conflict have shaped the logics of gender security in Serbia. Analysing claimed significations of "gender security" illustrates how the performance of "gender security" is political, because it is intimately linked to visions, perceptions and beliefs about conflict, post-conflict, and the future direction of Serbia. As outlined in the previous chapter, the women's and feminist movement in Serbia incorporates a diverse range of political, strategic, personal and practical attitudes towards feminism. These gender politics may reflect attitudes held by that individual or organisation in relation to war, nationalism or/and political responsibility. These perspectives about war and conflict are revealed through a temporal analysis which focuses upon how past, present and future perspectives on conflict and postconflict shape the configuration of gender security. Consequently, this chapter will illustrate the significance of gender politics in the formation of gender security discourse. Those activists and groups, such as Women in Black, with a feminist, anti-nationalist pacifist stance have a clearly articulated and politicised perspective about feminist security that is explicit, while at the other extreme, activists and organisations that reject feminism have a very different, and, for want of a better phrase, an apparently non-politicised set of significations relating to security.

Operating with a framework concerned with the claimed signification of "security" will denote ways activists have signified security within a particular temporal context. Feminist activists in Serbia have sought to (re)conceptualise a personally and politically meaningful notion of security by drawing upon perspectives about/from the past, present and future. That is to say, the personal attitudes, perspectives, experiences and hopes of activists are negotiated within a range of political stances held by organisations. This chapter opens with some reflection upon significant considerations informing the analysis of "gender security" as a political discourse in Serbia. Attention then turns to an investigation of the range of claimed significations for "gender security" amongst feminist and women's activists in Serbia between February - August 2008. The final part of this chapter examines the temporality of these narratives relating to "gender security" to give some insights about how past(s), present(s) and future(s) of conflict and post-conflict are woven into both politicised and nonpoliticised significations of security.

\section{SECURITY AND POLITICS}

To make sense of the connections between the gender politics of the activist, and the configuration of gender security put forward, activists were asked what (gender) security meant for them. This revealed the claimed significations activists attached to "gender security". Understanding the claimed signification of "gender security" is tricky because of the layers of personal-political imaginations wrapped around a specific and particular configuration of "gender security". This section unpacks 
three analytical considerations affecting how the claimed signification of security is thought about, demonstrating the personal-political nature of a configuration of "gender security". First, issues relating to the translation of "security" between English and Serbian are touched upon, highlighting how translations could affect the political interpretations of the concept of "security". Attention then moves to understanding how "senses" of security are inscribed within personal experiences of insecurity: that is, personal senses of insecurity are sometimes transformed into political visions of security. Finally, this section outlines the social and political context surrounding the moment (February - August 2008) in which the interviews supporting analysis are located, highlighting the experiences and contemporary contexts potentially shaping activist responses to my question of what "security" means to them.

\section{Translating Security in and out of Serbian.}

"Security" can be translated into Serbian in two ways." First, as sigurnost, which is the translation frequently offered by dictionaries, referring to a sense, or feeling of security and safety. ${ }^{2}$ Sigurmost usually refers to non-physical security, such as financial security. Domestic violence shelters in Serbia are known as sigurna kuca: literally translated as safe house. The second translation, beabednost, forms the focus of this thesis. Beqbednost is considered a more serious word, and is generally associated with national and international security. For example, snage beabednosti refers to the armed forces; savet bezbednosti is the translation for the UN Security Council; the Organisation of Security and Cooperation in Europe (OSCE) is known as Organizacija za Evropsku Beqbednost i Saradnju (OEBS). While it would appear that bezbednost reflects the ontological logics of state security, this is starting to change. Serbian translations of UNSCR 1325 generally refer to beqbednost, especially in the literature produced by Women in Black, where it is referred to as the rezoluciju zene, mir, beqbednost (literally: Resolution Women, Peace, Security), although in the translation of the text of actual resolution offered by PeaceWomen, it occasionally refers to mira $i$ sigumosti (peace and security). ${ }^{3}$ These differences in translation are reflective of the way that sigumost and beabednost overlap. More importantly, these differences are indicative of how meanings can never be directly translated, as a translation cannot be made to signify the precise meaning intended in another language.

\footnotetext{
'With special thanks to Predrag Obučina, Gordana Radaković and Adam I Jardie for their time and care in explaining the differences to me. Any mistakes are my own, and the choice to focus upon bezbednost was my own decision.

2 V. Bilbija and B. Simić Rečnik Englesko-Sppski, Sipsko-Engleski (Star Publications, New Duhli, 2003), p. 301.

${ }^{3}$ For examples of how Women in Black refers to UNSCR 1325 in Serbian, see S. Zajovic Od Trudicionalnog do Feministitkog koncepla besbednasti Rezolucija 1325 (From the Traditional to the Feminist Concept of Security: Resolution 1325) (Women in Black, Bulgrade, 2007). All PeaceWomen translations can be found at her://www.peaccwomenorg/1325inifonshation/indes.heml [accessed 3 June 2010]. My own translations from Serbian.
} 
How "security" is translated and thought about matters, as these translations shape, limit and make possible a particular political vision of security. There are some slight differences between the Serbian, Croatian and Bosnian translations of UNSCR 1325 placed on the PeaceWomen website: the Bosnian translation is the only one that refers to zene, mir $i$ sigurnost in the subheading. While in theory, either sigumost or bezbednost could be used, in local practice, the implications suggested by one word over another could potentially lead to very different gender consequences in terms of the frameworks and thinking behind the programmes and actions taken by those claiming political authority over UNSCR 1325. Soumita Basu relates an anecdote about the PeaceWomen translations project, recalling how she persuaded her mother to translate UNSCR 1325 into Bengali: the translation was literal and not reviewed before being placed online. 4 The translation of "security" opens (another) space for multiple interpretations of the concept, potentially affecting personal and political responses. The question of how to translate "gender security" (iterally) affects the question of how "gender security" is translated (in practice): that is, the way in which "gender security" is translated into a local language could affect the specific vision and ambition of "gender security".

Derrida suggested that since a "pure" translation is impossible, we should instead consider the notion of 'transformation' to 'substitute for the notion of translation: a regulated transformation of one language by another'.5 That is, the meaning of "security" in English can never be directly translated to beqbednost or sigumost as it cannot signify the same thing as in English, but through' a series of choices, it is possible to transform from one language to another. With the discourse of "security", there is an additional complexity relating to increasing global connections and the presence of international post-war reconstruction and development programmes in Serbia. Since the international "community" has been strongly promoting alternative conceptualisations of security over the past decade - for instance; through UNDP notions of human security, or the gendered security embodied in UNSCR 1325 - it is almost inevitable that there will be a discursive spillover into formal and informal venues. The impacts of these international and transnational discourses will become clear in chapters five and six, but for the moment, it is worth pointing out that the discursive (re)signification of bezbednost is product/productive of increasing (international) ideas on/about gender security. While there is no such thing as "pure" translation, it can be argued that the discourse of security is being transformed and contextualised globally, with an increasing emphasis upon statements of human and individual security, feeding into notions of security articulated and represented by activists in Serbia.

\footnotetext{
4S. Basu 'Security Through' Transformations: The Case of the Passage of UN Security Council Resolution 1325 on Women, Peace and Security' PhD Thesis, Aberystwyth University, 2009, p. 205.

'Derrida Positions, cited in G. C. Spivak 'Translator's Preface' in J. Derrida O/Grammatology, (The John Hopkins University Press, Baltimore and London, 1997) p. Ixxxvij.
} 
The subtle variations between bezbednost and sigurnost bring many advantages to analysis of security as a discourse. Ole Wæver points out that (in English) security has several connotations: from its 'everyday meaning (being secure, safe, not threatened)... and images derived from the "international" discussion of national security, security policy'.6 These multiple linguistic connotations are not quite the case in Serbian: even in interviews conducted entirely in English, I frequently clarified what kind of security I was interested in exploring by reference to the Serbian beqbednost. The more precise (preexisting) meanings attached to bezbednost and sigumost allow more rigorous analysis of the extent to which the concept of security (in the bezbednost sense) has been politically (re)signified or (re)imagined, enabling identification of where the concept has been (re)conceptualised for a particular political purpose or desire. Beqbednost is (and sometimes not) being (re)conceptualised by women's and feminist organisations in Serbia: any (re)signification is based upon relationships and connections made with other signifiers, drawing upon memories, perspectives, hopes and experiences. Ultimately, the way in which activists translate - or transform - "gender security" has implications for the extent to which they (re)conceptualise (gender) security.

\section{Security via (in)security.}

Before activists can articulate or represent security, it needs to be signified. To reflect their political beliefs and values, it may be that security needs to be explicitly or implicitly rethought and resignified, a process that some activists have gone through. However, not all activists have explicitly thought about meanings of beqbednost. sometimes when I interviewed them it was the first time that they had a (public) space to reflect upon how personal senses of (in)security could connect to their activism. Despite this, activists - regardless of the extent to which they had deliberated upon the concept of "security" - tended to articulate similar understandings and concerns in relation to (in)security. However, especially striking was that although activists had often identified the same gender security problem, the precise framing of the issue varied. The specific framing of (in)security is connected to their political identity. These political identities were forged out of experiences, attitudes, interpretations and perceptions about the pasts, presents and futures of conflict and post-conflict in Serbia. That is, temporal personal-political imaginations of conflict and post-conflict are woven into the gender politics of activists, shaping the precise configurations of (in)security, and thus, the political construction of "security".

๑ O. Wxver 'Securitization and Desecuritization' in R. D. Lipscutz (ed.) On Secwrity (Columbia University Press, New York, 1995), p. 50. 
Activists, when asked what security meant to them, started from the position of what made them feel insecure, and from this articulation of insecurity, they (sometimes) flipped the coin around to state a position on "security". That is, personal experiences are articulated as moments of "insecurity", and from those moments of insecurity, a political position on "security" can be represented. Two points can be usefully drawn out here. First, activists claimed signifiers of security grounded within their personal experiences. The importance of personal experiences in making and supporting a signification of "security" should not be discounted. A central feminist assertion has been 'the personal is political': political imaginations are derived from personal experiences, and personal experiences are potentially political. 7 These personal experiences are frequently articulated as senses of insecurity: what activists feel, hear, see as insecurity, which (as a result of in/security's very duality) shapes perceptions of security. Christine Sylvester argues that analysis of sensory experiences of war and violence constituting in/security has not usually been on the IR agenda, as IR tends to 'shy away' from such discussions. ${ }^{8}$ The focus upon a 'sensory' notion of (in)security means starting from a consideration of how 'security hurts or annoys us as individuals. We might think, that is, about what security feels like and does not feel like'.? Through thinking about what makes them feel insecure, it is possible for activists to draw wider political notions about security. By drawing upon personalpolitical imaginations of experienced or recalled past and present insecurity, that is product and productive of imagined security in the future, activists construct a specific notion of (in)security consistent with their personal-political vision.

Second, their discourses of security are simultaneously inscribed through discourses of insecurity. The political vision of (in)security can be understood through 'turning to the word [of security] itself.10 Michacl Dillon explores the construction of security, arguing that "security" occurs through its very opposite: insecurity. In part, this is because 'any discourse of security must always already, simultaneously and in a plurality of ways, be a discourse of danger too'.11 Hence, 'insecurity is always already and simultaneously inscribed within security', and so there is a constant tension and duality at the heart of security discourse.12 By recognising the duality of security, it is possible to draw out the political nature of the personalised stories - which many activists did themselves. For instance, Jovanka Brikić, the coordinator of Women in Action, located in Velika Plana, a small town south-east

\footnotetext{
'C. Enloe Bananas, Beaches and Bases: Making Feminits Sense of Intemational Politics (University of California Press, Berkelcy, 2000), p. 195.

- C. Sylvester 'W/2, Sense, and Sccurity' in L. Sjoberg Gender and Intermutionul Secwrity; Femintist Peripectites (Routledge, London, 2009), p. 24.

'Ibid., p. 26.

${ }^{10}$ M. Dillon Politics of Security: Towards a Political Philosophy of Continental Thought (Routledge, London, 1996), p. 119.

"Ibid., p. 121.

12 Jbid., p. 127.
} 
of Belgrade, describes an incident where the daughter of another activist was mugged at knifepoint.13 She then says;

Plana was always a relatively quiet and safe town... security in general is significantly lower. This is not just a feeling, this is not some kind of paranoia... [Security is reduced because of] war, transition, poverty, rather than [the end of] Communism. We are faced with the weakness of state institutions in dealing with prevention and confrontation of violence'. ${ }^{14}$

To prompt this line of discussion, I asked "what does security mean to you?" The response focussed upon senses of insecurity - a frequent occurrence during interviews - highlighting the significance of the duality at the heart of "security", which is simultaneously inscribed through the articulation of insecurity. The tensions constituting (in)security is product and productive of political imaginations: as Dillon puts it, (in)security 'is the opening which calls forth the prospect of a political life'.15 Jovanka relates her sense of insecurity to a range of structural factors - war, transition, poverty - and identifies the source of the problem to be the state, giving a political explanation for a personal sense of insecurity, hinting at what is necessary to secure security. Thus, (in)security crafts political visions in terms of identifying the sources of (in)security in the past and present, and the steps needed to achieve security in the future.

Jovanka's narrative highlights the transformation from the personal experiences and feelings (the daughter of another activist having been mugged) to the political (the state needs to be more effective), suggesting that discourses of in/security are connected to (political) identities claimed by activists, crafting a personal-political imagination of security. This follows Maria Stern's claim that 'who (we say) we are matters in how we conceive of, strive for, and practice security', since how we 'name danger and threats, as well as safety and well-being' not only inscribes constructions of (in)security, but also 'implies (and indeed informs) a particular expression of our identity'.16 The political identities of activists from Serbian feminist and women's organisations in relation to the extent of their political opposition to state security narratives affects the specific framing of their security stance. These identities are crafted through processes of inclusions and exclusions. In essence, frameworks of (in)security exclude and/or include connections to narratives of conflict and post-conflict: giving a different comprehension and rationale for the same gender insecurity problem articulated by activists. Readings of conflict and post-conflict through activist articulations of (in)security is indicative of the personal-political imaginations that assemble senses of what gender

\footnotetext{
${ }^{13}$ Interview, Jovanka Brikić, Coordinator, Women in Action, Velika Plana, 17 April 2008.

14 Ibid.

15 Dillon Politics of Security, p. 128.

${ }^{10}$ M. Stern Naming Setwriby - Constructing Identity: 'Mayan-women' in Guatemala on the ete of 'peace', (Manchester University Press, Manchester, 2005) p. 7.
} 
security might mean. Notions about pasts, presents and futures of conflict and post-conflict interact to forge our personal-political imaginations of (gender) security, through a duality and tension with insecurity.

\section{Temporality and "Security".}

The articulated discourses of security are, as stated in the preceding paragraphs, constitutive of specific configurations of personal-political identities. However, these discourses were articulated within a particular temporal moment, where the responses are embedded within a broader temporal context. That is, the signifiers that activists claim to connect to security are articulated within a specific slice of time - the so-called "present" - but this moment in time is profoundly affected by personal-political imaginations of pasts and futures. By focussing upon interview data with activists from feminist and women's organisations in Serbia to highlight ways they signified security between February - August 2008, I aim to expose how personal-political temporal imaginations of conflict and post-conflict are woven through their security discourse. Like Maria Stern in her study of Mayan women in Guatemala on the "eve" of a peace agreement in 1995/6, this study exposes a curiosity about how participants spoke about their experiences of insecurity and security, and what this might imply for considerations of security and insecurity within international relations. ${ }^{17}$

Limiting my timeframe to February - August 2008 is designed as a restraint to partially fix a signification within a particular temporal moment. While the thesis as a whole has a broader timeframe, it is necessary to make sense of the signifiers (partially) fixing the discourse of security, to understand the ways in which gender politics shapes the specific discursive configuration of "gender security". A brief explanation of a range of apparently relevant moments during my field research which activists connected to their significations of (in)security is given in the following paragraph. Through highlighting motifs regarding pasts, presents and futures woven through the personal description of "security", we can generate some ideas about the ways that security has been signified. Locating these significations within a specific and bound epoch restrains the temptation to undertake a genealogical analysis of security discourse, where the political significance of any discursive shifts are identified. Instead, through examining how time has been woven into a particular signification of security at a specific and fixed time, the ways that political values and objectives shape, (re)construct, and (re)produce various (re)conceptualisations of security can be assessed.

\footnotetext{
${ }^{17}$ M. Stem 'Racism, sexism, classism, and much more: reading security-identity in marginalized sites' in B. A. Ackerly, M. Stem, and J. True Feminist Methodologies for Intemational Relations (Cambridge University Press, Cambridge, 2006), p. 175.
} 
Since these meanings are located at a very specific temporal moment, it is worth briefly outlining the key political events that occurred in Serbia during early 2008: the context and immediate concerns affected how the interviewee (and interviewer) responded. ${ }^{18}$ I embarked upon my field research just after Kosovo proclaimed independence from Serbia on 17 February 2008, an event that renewed vigour for a long running debate about the place of Kosovo in Serbia, and which dominated social and political concerns for the remainder of my fieldwork. Shortly after Kosovo's proclamation of independence, there were nationalist riots in Belgrade, culminating with the American embassy being set on fire. For some weeks after this, demonstrations and marches were banned, including the planned peaceful march and performance to be held by feminist organisations in Belgrade for International Women's Day, 8 March (held eventually on $15 \mathrm{March}$ ). In the meantime, the coalition Government collapsed over debates about how to respond to Kosovo's declaration of independence, and the recently elected, centre-left, pro-EU president Boris Tadic called for parliamentary elections to be held on 11 May 2008. The election campaign that followed was polarised over the issues of EU membership and the status of Kosovo. A new coalition government, which would not recognise the independence of Kosovo, was formed on 7 July, with a majority supported by pro-European Union parties. Soon after, Randovan Karadžić, a fugitive war criminal wanted by The Iague, was arrested in Belgrade, triggering localised demonstrations that took place daily against the Government, the EU and Kosovo's declaration of independence. These contemporary political and social contexts provide a backdrop to activist configurations of "gender security" at that moment.

The temporality embedded within activist significations of security reverberates through articulations and representations of the discourses surrounding the policies and actions of activists. In Judith Butler's analysis of the discourses surrounding hate speech, she highlights issues with temporality in the (re)construction of hate speech, which can be utilised in relation to security discourse. She argues that

\footnotetext{
The present discourse breaks with the prior ones, but not in any absolute sense. On the contrary, the present context and its apparent "break" with the past are themsclves legible only in terms of the past from which it breaks. The present context does, however, elaborate a new context for such specch, a future context, not yet delineable and, hence, not preciscly a context. ${ }^{19}$
}

This highlights how various temporal contexts are interwoven together within any signification, articulation or representation. As outlined in chapter one, a discourse has multiple temporalities embedded within its discursive field. Interactions between various pasts, presents and future are product and productive of each other, and this interaction is what enables signification within a

\footnotetext{
18 The political events discussed here are based upon my field notes and so should not be seen as a complete record: it is more of a reflection of my diary entries about what I felt influenced the interviews. Indeed the "selection" of events are indicative of concerns voiced by my interviewees and the nature of this selection would be a research project in its own right.

${ }^{19} \mathrm{~J}$. Butler Exritable Speecb: A Politics of the Performative (Routledge, London, 1997), p.14.
} 
particular (partially) fixed temporal moment. These temporal moments, whether implicitly or explicitly articulated and represented are located within the political framework limiting, making possible, or constituting security discourse.

As discussed in chapter one, the subjective nature of personal-political imaginations constrain and make possible how "gender security" is conceptualised. Working from the perspective that personalpolitical imaginations are knowledges forming the subject to be constructed and deconstructed, there are a number of considerations that need to be accounted for when evaluating the claimed significations associated with "gender security". These considerations include translation issues, how the "sense" of security is interpreted through the duality of insecurity, and the temporal moment from which activists are speaking. The political construction and practice of "gender security" are product and productive of the considerations discussed in the preceding paragraphs as they limit and make possible the personal-political imaginations that shape meanings of "gender security".

\section{SIGNIFYING SECURITY}

The following paragraphs highlight the temporality embedded in security discourse. The analysis draws upon responses to a question that was asked of every activist: what does "security" mean to you? Examining the utterances reveals the immediate connections that people make, and the connections that they wish to explicitly make clear. This approach gives a sense of some of the significations that cluster around security. Additionally, the responses to the direct question of "what does security mean to you" illuminated the politicised extent of "security" for participants. Analysis of 48 relevant interviews conducted with 69 activists indicate a number of similar concerns: for example, 22 responses highlighted social censorship of political dialogue as a security concern, while 15 responses mentioned economic insecurity. ${ }^{20}$ There are significant overlaps between various issues; for example, between the insecurity of human rights defenders and censored political dialogue: they are shaped by similar concerns and perceptions about pasts, presents and futures. Consequently, the analysis is constructed via three generalised significations, thematically arranged, highlighting ways that pasts, presents and futures are woven into significations clustering around the articulated and declared signification of security.

\footnotetext{
${ }^{20}$ Not all interviews were included: for example those interviews with people working in international institutions (therefore not NGO activists); that took place in Kosovo (not considered Serbia for the purposes of this project); or were conducted on my follow-up research trips in June or September 2009 (different temporal moment) were excluded.
} 


\section{(1) Connection of security with human rights}

'Human rights means [that] human beings are safe and free, and security means the same. For me, fighting for security and human rights is completely the same... human rights means quality of life, with respect to the right of others. And security means to be free and to feel like a man, not to be afraid, to live a good quality of life with your own choices'.21

It is not especially surprising that activists connected security with human rights, or values normally associated with human rights, as both notions about human security and human rights have similar organisational and discursive logics. Human rights discourse is based upon a notion of rights: but how these rights are arrived at is a subject of dialectical conflict. The first camp can be loosely described as foundationalist, which justifies human rights on the basis of supposedly objective reason and morality, and argues for universal values. ${ }^{22}$ The second, anti-foundationalist, camp emphasises contingency, construction and relativity, arguing for a recognition of the particularity of rights. ${ }^{23}$ For feminist activists, particularly those connected to Women in Black, both human rights and human security emphasise a moral concern for the individual, move away from state-centric reasoning, and both share a similar foundationalist ontology. ${ }^{24}$ The most prominent human rights/human security concept articulated by activists in early 2008 was freedom, astutely highlighted in the example quotation above by Biljana Kovaćević-Vućo, the chair of Lawyers' Committee for Human Rights and a Women in Black activist. She outlines the connections between human rights and human security, highlighting the importance of freedom in enabling a decent quality of life.

For many activists, the absence of human rights is an insecurity problem linked to patriarchy. In the quotation above, Biljana highlights that 'security means to be free and to feel like a man', suggesting that her insecurity is a consequence of her biological sex. A similar statement is made by Staša Zajović, the coordinator of Women in Black, Belgrade: for her, 'security is the achievement of my [right to be] different - I don't want to live according to patriarchal rules and I shouldn't be condemned because of that'. ${ }^{25}$ The insecurity resulting from lack of freedom is a consequence of patriarchal structures within Serbian society that oppress women. For some activists, including Staša, patriarchal structures are a consequence of nationalism, which

\footnotetext{
${ }^{21}$ Interview, Biljana Kovaćević-Vućo, Director, Committee of Lawyers for I luman Rights, Bclgrade, 30 July 2008.

${ }^{22}$ M. Desai 'Trom Vienna to Beijing: Women's Human Rights Activism and the Human Rights Community' in P. V. Ness (ed.) Debating Human Rights: Critical essays from the US and Asia (Routledge, London, 199\%), p. 184.

${ }^{23}$ Ibid.

${ }^{24}$ See T. Dunne and N. J. Whecler (eds.) Human Rights in Global Politics (Cambridgc, Cambridge University Press, 1999), especially the contributions in part one for an overview of theories about universal human rights.

${ }^{25}$ Interview, Staša Zajović, Coordinator, Women in Black, Belgrade, 29 June 2008.
} 
'endangers the security of women, because [it means] that women must be obedient and guardians of tradition and nation and they are supposed to preserve ethnicity for the sake of national security... according to my experience in ex-Yugoslavia, [being a nationalist or being a feminist] are two opposite paths'. ${ }^{26}$

Staša's sense of insecurity is related to her perceptions about the consequences of war and nationalism, affecting the logics through which present insecurities are viewed. These logics emphasise the long-term impact that conflict has upon gender security.

Experiences related to the impact of war and conflict upon present-day in/security were asserted in activist inscriptions of insecurity as the absence of freedom of speech, particularly the lack of freedom in political expression. In this context, restrictions upon freedom of expression do not necessarily relate to state control, but rather, what constitutes a socially acceptable political position. Certainly, during the 1990s, there was much political repression, as Ljilja Radovanović, a Women in Black activist highlighted: 'when all that [war, nationalism] started, you could be punished for only one spoken or unspoken word' that opposed the state. ${ }^{27}$ However, it is the "post-war" era that poses the most pressing concern to some activists. Ljilja contends that 'even now, if you express your disagreement [with the state] it is viewed as an issue of national importance... [there is a] national consensus, a state-religious [value] that you are not allowed to question'.28 Indeed, in the "post-war" era, many activists are concerned with the perceived need for self-censorship, to moderate their own views which may not be socially acceptable, to maintain their personal security.

Following Kosovo's declaration of independence on 17 February 2008, some activists perceived an increase in social pressures preventing activists feeling secure in expressing socially unpopular ideas. For instance, Jovanka Brikić, a coordinator of a women's group in Velike Plana, central Serbia, felt that,

'From February 17, this autocensorship is growing. I think that each of us in any kind of dialogue related to political issues are intuitively trying to anticipate the political attitudes of the person they are speaking to, and measuring what $s /$ he can or cannot say... this is a step backward drastically, ${ }^{29}$

Time here is discursively constructed as a progressive force that has been halted. There is an underlying implication that until Kosovo declared independence, social acceptance of particular political perspectives had been growing: once Kosovo declared independence, 'a step backwards' was

\footnotetext{
26 Ibid.

27 Interview, Ljilja Radovanović, Women in Black activist, Belgrade, 7 July 2008.

2a Ibid.

${ }^{29}$ Interview, Jovanka Brikić, Coordinator, Women in Action, Velika Plana, 17 April 2008.
} 
taken and self-censorship increased. Those who vocalise support for Kosovo's independence are posited as "anti-Serbian" and risk (extreme) nationalist, "Kosovo is Serbian" wrath. ${ }^{30}$ The perceived need for self-censorship within society increases senses of insecurity: hence security is connected to freedom of expression.

For those activists who question the state and insist upon the need to the face the past, there is an anxiety with their own security as human rights defenders, a concern related to freedom of political expression. ${ }^{31}$ On March 15 2008, during a performance for International Women's Day, Stasa Zajović, the coordinator of Women in Black - Serbia, climbed up the steps of a statue in the middle of the Trg Republike, the main square and thoroughfare in central Belgrade, with a megaphone, yelling "Mladić in The Hague!", "Karadžić in The Haguel".32 Jovanka Brikić recalls 'looking around... I understood that it was very brave to say that even in Belgrade: even though the police were protecting us'. ${ }^{33}$ Jovanka's concern was not unusual: many Women in Black activists highlighted their sense of insecurity during public events: several peaceful demonstrations over the past twenty years have been met with violence, abuse and tear gas. These concerns for physical security have another dimension: their own workplaces. Ivana Radović, the coordinator of the Prevention and Education programme within ASTRA anti sex-trafficking relates that "until 2006, we had an office in a different place and we had a secret address... it wasn't for public use, we'd see our clients [in another office]. After [2006] we moved and opened a daily re-integration centre... we are aware that our work is dangerous and we receive many threats on the telephone'. ${ }^{34}$ The current offices of ASTRA are equipped with CCTV cameras for this reason. ${ }^{35}$ Activists who are aware that they are expressing a political position that is socially unpopular feel insecure when publically vocalising these stances. As a consequence, security is connected to the need to feel safe to express particular political views.

\footnotetext{
30 For example; in February 2007, the Belgrade daily newspaper, Kurir, published an article headlined 'Prison: Members of Ceda's coalition and Women in Black may face up to 15 years in prision for advocating an independent Kosovo'. The article demanded that members of Women in Black should be subject to public prosecution and criminal charges should be instigated against them for stating the view that Kośovo should be independent from Serbia. See www.enchssmomory and www yucomorg.rs for further details and more examples [accessed 8 June 2010].

${ }^{3}$ Multiple press releases and reports have been publicised to highlight the insecurity of human rights defunders in Serbia. Sce for example: Campaign To Promole the UN Deckaration on Human Rights Defenders in Serbia Report, YCOM, (January 2009; www.jucom.ory. Is retrieved 19 May 2009), Incest Trauma Centre 'Announcement: Women's IR Defenders Summit' (July 2007; wone.inccistraumaccntec.ord.5s retrieved 19 May 2009) and Women in Black Women For Peace (Women in Black, Bclgrade, 2007) pp. 203 - 220.

32 Randovan Karadžić and Ratko Mladić are both accused of war crimes and wanted by The Hague for face these accusations. Mladić is still at large as of June 2010; while Karadÿić was arrested in July 2008. It was/is thought that the governments of Serbia are aware of the location(s) of the fugitive(s).

${ }^{33}$ Interview, Jovanka Brikic, Coordinator, Women in Action, Velike Plana, 17 April 2008.

34 Intervicw, Ivana Radovic, ASTRA Anti-sex Trafficking Awareness officer, Belgrade, 17 April 2008.

35 Interview, ASTRA Network Administrator, Belgrade, 17 April 2008. These concerns are not just limited to ASTRA: many organisations do not reveal their addresses in public or are fearful of attacks to their premiscs.
} 
A sense of "security" signified as human rights was also connected to freedom of movement. Prior to December 2009, a Serbian passport carried heavy visa restrictions in terms of entry to other countries. ${ }^{36}$ Activists made statements like 'we want to travel, and it is difficult here to cross the border, this is a reason to feel insecure... we used to have these red passports [Yugoslavian passports were red] when we travelled everywhere'. ${ }^{37}$ Pride was taken in the relative freedom that Yugoslavian citizens had in terms of travelling, especially during the 1980s, and woven into these accounts is a sense of loss that this freedom is no more. ${ }^{38}$ It was perceived that travel during the 1970 s and 1980s had been very easy compared to early 2008 , where people were less able to travel and consequently feel trapped. This signification of in/security as freedom of movement is based upon temporal perspectives and beliefs about the past compared to the present. Two temporal moments are contrasted to each other: a past with red Yugoslavian passport that enabled travel compared to a present of restriction.

The tempo-spatial dimension and interconnection of the signification of security as freedom of movement is revealed in the role that the notion of "post-conflict" plays into these statements. Paul Higate and Marsha Henry, in their analysis of peacekeeping in Liberia and Kosovo found that peacekeepers are frequently viewed as 'agents of spatial power whose practices actively configure security possibilities on the ground'.30 For example, in response to the perceived threats to their security, the Serbian minority in Kosovo would rather travel sixty miles to another "Serbian" settlement instead of the nearest "Albanian" town: international peacekeepers from UNMIK and KFOR have responded by providing protected transportation and building roads connecting Serbian settlements.40 Certainly, conflict in Kosovo has enhanced senses of insecurity in the post-conflict era for the Serbian minority, affecting freedom of movement. The issue of visa restriction in Serbia is very different, but tempo-spatial dimensions about conflict and "post-conflict" still play through activist significations of (in)security: in other words, before the wars, travel was not a problem. In this signification of (in)security, notions about "post-conflict" are woven throughout. The December

\footnotetext{
36 On 19 December 2009 , Serbia was placed onto the "positive Schengen list", enabling visa-free travel to most EU countries (with the exception of the UK and Ircland). Prior to this, getting a visa was a frustrating, difficult and expensive procedure: for example, an acadcmic presenting a paper at a three day conference in Poland would only be given a three-day visa for Poland. Furthermore, students and those not formally employed were rarely granted a visa.

37 Interview, Smiljka, VIVISECCT Activist, Novi Sad, 9 July 2008.

33 For momories concerning the freedom to travel during the 1970s and 1980s see Slavenka Drakulić How W' Sunvived Communism and Eten Laughed (Vintage, London, 1992) and Cafe Eumpa: Ljfo Affer Communism (Abacus, London, 1996), especially pp. 28 - 31.

39 P. I ligate and M. I lenry Insecune Spaces: Peacekeeping, Power and Performance in Hait, Karoro and Liberia (Zed Books, London, 2009$)$, p. 83.

40 lbid., p. 78-80. Higate and Henry suggest that this particular performance of insecurity enacted through UNMIK and KFOR strategy has actually enhanced perceptions of insecurity.
} 
2009 removal of visa restrictions for Serbians citizens visiting Schengen list countries served to highlight discursive connections with notions of "post-conflict". The changes to visa rules and regulations were, and are, discursively connected to an image of progressive EU membership for Serbia: in other words, moving away or even a disassociation with/of the "post-conflict" past. ${ }^{41}$

For many activists, the discursive terrain of security is connected to human rights, including the right to freedom of movement and expression. The logics explaining the senses of insecurity arising from a lack of human rights are connected to notions about conflict and post-conflict pasts, presents and futures. How security is connected to human rights is dependent upon the personal-political imaginations of conflict and post-conflict held by individual activists or organisations. Generally, the more that an individual or group believes in the need to accept political responsibility for the war crimes committed by the Serbian state during the 1990s, the greater the likelihood of relating security to freedom of expression, and feeling safe to express these views. This is very simply because expressing a belief in political responsibility leaves activists exposed to violence, abuse and threats, placing them into a position of insecurity. These experiences of insecurity are related to the problems of the post-conflict present: that is, many activists believe that nationalist views cultivated through the policies of the Miloševic regime during the 1990s continue to shape social and political values today, making it difficult to express their political views. Freedom of movement in relation to opportunities to travel is an issue with less overt political connotations, and was stated as a security issue by a wider range of activists. The visa restrictions are located within a narrative that compares the pre-war era with the present: to secure security in the future, travel restrictions need to be eased. Future hopes and aspirations regarding the achievement of freedom of movement and expression are șhaped through how the activist or organisation frames the conflicts of the past and problems of the "postconflict" present.

\section{(2) Structural logics of in/security: Women-specific security concerns}

Although the nature of the sample (activists of feminist and women's organisations) means that all claimed significations of security were highlighted as gendered in some way; specific female issues including violence and inequality were explicitly described as a security concern by activists. ${ }^{42}$ Through gendered lenses, it is possible to identify violences not normally recognised as a security concern, expanding what is conceptualised as security. By placing at the forefront women's (in)security issues, the ways that "women" are constituted - and, more often, ignored - by a host of

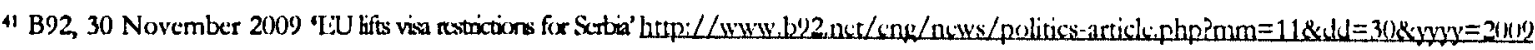
[accessed 8 February 2010].

42 This is not to say that men do not experience gender violence. 
other actors, practices and levels' concerned with security are revealed. ${ }^{43}$ Generally, activists noted gender violence and gender inequality as issues of gender insecurity, but their gender politics shaped the framing of the concern. For instance, while most (not all) activists explained violence and inequality through a reasoning concerned with the hidden gender structures embedded within society, some extended their explanations to make connections between violence and inequality and the longterm impacts of war and nationalism. Exposing various temporal discourses about conflict and postconflict within the articulated personal-political imaginations of activists illuminates the range of gender politics that enables alternative configurations of gender security.

To take just one example, these subtle differences in articulated understandings of gender (in)security are illuminated in discussions of what is described as the 'retraditionalization of women's identities, social roles, and symbolic representations'.44 In Serbia, these retraditionalizations are generally linked to Eastern Orthodoxism, notably the Serbian Orthodox Church, or Islam, which is the dominant religion in south-west Serbia. For Zibija Dh-Šarenkapić, the coordinator of a women's human rights organisation in Novi Pazar, south-west Serbia, a source of insecurity is retraditionalization. The consequences of retraditionalization noted by $\mathrm{Zibija}$ include reductions in abortion rights, increasing inequality during marriage, different social expectations governing women's bodies (i.e. the expectation that women will be virginal and cover her hair), and an increasing withdrawal of women from the public sphere. ${ }^{45}$ Zibija argues that retraditionalization is a consequence of economic factors:

Women used to be socially visible and economically independent: now a lot of women are unemployed, the factories are closed down, large numbers of women have returned to the role of housewife, thinking about how to make lunch out of very little... $60 \%$ of women are unemployed. If we oppress the women we are increasing the power of religious communities. 46

Another activist, Ljilja Radovanović, from Women in Black, also highlights retraditionalization as negatively affecting women's security, because 'the material status of women [and] reproductive rights are being encroached upon, women are in a worse position concerning their right to abortion'.47 However, Ljilja contends that retraditionalization is a result of 'pressures due to the strengthening of nationalism and clericalism and these phenomena are, as we know, related to the war'.48

\footnotetext{
43 L. Hansen and L. Olsson 'Guest Editors Introduction' Securiy Dialogue, 35, 4 (2004), p. 408.

4 Ž. Papić Women in Serbia: Post-Communism, War, and Nationalist Mutations' S. P. Ramet Gender Politics in the Western Balkans; Women and Sacitey in Yugaslatia and the Yugaslav Successor States (Pennsylvania State University Press, Pennsylvania, 1999), p.154.

45 Interview, Zibija Dh-Šrenkapić, Coordinator of DAMAD, Novi Pazar, 12 July 2008.

4 Ibid.

47 Interview, L.jilja Radovanović, Women in Black activist, Belgrade, 7 July 2008.

4 Ibid.
} 
Both explanations have a temporal dimension: for Zibija, women used to be socially visible and economically independent, while Ljilja points to 'the war' as the moment of change. Zibija's rationalisation places emphasis upon present-day economic factors, making no direct or explicit connection to the wars. When asked if retraditionalization could be defined as a post-conflict problem, Zibija agreed to an extent, identifying an increase in retraditionalization after 1995 and 2000, but stresses that 'we were simply on the edge of conflict, um... in neighbour'. 49 The implication is that conflict is not the cause of retraditionalization, but retraditionalization is one of the features of (what is problematically defined as) a post-conflict era. However, for Ljilja, retraditionalization is obviously a social consequence of conflict: she states that 'as we know, [retraditionalization is] related to the war'. ${ }^{50}$ By highlighting nationalism, she suggests the nationalist war policies of the $1990 \mathrm{~s}$ continued to affect social and political life in the post-conflict era: in essence Ljilja's discursive logics behind this particular signification of (in)security points to a narrative emphasising retraditionalization as a consequence of war.

Similar organisational logics are deployed by activists to explain other women-specific security concerns, including domestic violence, sex trafficking, freedom of sexuality, and misogyny in society. Factors such as the disproportionate numbers of men and women in political positions is highlighted as a source of insecurity. One activist, who described herself as a feminist-antimilitarist, argued that 'if we can achieve greater participation of quality women in decision-making, in Parliament, ministries, and so on, [the] influence of women on questions of security, resolving military issues, on security of the country, they would contribute different solutions',51 The explanation offere here mirror the discursive logics of a critical-liberal ontological approach to security: by addressing the structural disparities between men and women, it is possible to achieve a different kind of security that deals with military matters in alternative ways. These rationalisations point to structural factors, specifically political institutions, as a cause of gendered insecurity. Amongst some activists involved with so-called "political" organisations, there is a belief that war, nationalism, and multiple transitions have weakened political institutions in Serbia, generating a culture where there is a lack of will to deal with gender violences and inequalities. ${ }^{52}$ For these feminists, the shaping of institutions and

\footnotetext{
49 Intervicw, Zibija Dh-Sarenkapić, Coordinator of D AMAD, Novi Pazar, 19 July 2008. 1925 was when the Dayton Peace agreement was established, formulating a peace settlement for Bosnia-Herzegovina, 2000 is after United Nations Sccurity Council Resolution 1244 (adapted 1999) placed Kosovo under UN administration.

so Interview, Ljilja Radovanović, Women in Black activist, Belgrade, 7 July 2008.

51 Interview, Nevanda, Women's Alternative activist, Kikinda, 29 April 2008.

32 Interview, Jovanka Brikić, Coordinator, Women in Action, Velika Plana, 17 April 2008.
} 
patriarchy that affect gender (in)security has been influenced by the processes and impact of war and nationalism.

Security is not necessarily signified through links to formal institutions and structures. Sometimes these structures are less tangible. For some activists, 'security is a feeling that there are mechanisms and spots, places in my community where I can solve the problems I have'. 53 The need for 'a room of one's own' is important for escaping the patriarchal structures within society. Jasmina Mitrović, a Women in Black and SOS Hotline activist in Valsotinice, southeast Serbia argued that "women in south Serbia don't feel secure mostly because $95 \%$ of women are dependent upon their families, husbands. They don't have a chance to express themselves and to become independent'. ${ }^{54}$ The very structure of patriarchy is viewed as a insecurity issue in its own right, as well as being a cause of other gender-specific security concerns. Gender - specific issues including the impact of religious fundamentalism upon women's rights, domestic violence, sex trafficking, the lack of gender equality in society and politics, and misogyny were all highlighted by activists to be a (in)security concern arising out of gendered structures embedded in society. These significations point to patriarchal structures as a factor for women's gender insecurity. What differentiates "political" and "nonpolitical" organisations is the extent that war and nationalism is viewed as a structure and/or process that amplifies patriarchy, affecting gendered violences and inequalities that have a detrimental impact upon gender (in)security. For instance, while the politicised feminist activists discursively connected domestic violence to war and nationalism during the 1990s, many women's organisations did not.

\section{(3) Insecurity following transitions affecting "everyday life".}

Activists signified security by highlighting feelings of insecurity affecting daily life, including; economic anxiety, concerns about education or health, an inability to plan for the future, fears for their own children, and apprehension about their own safety in the community. In some cases, there is a reflection between these significations stated by activists and the ideas embodied within the UNDP definition of human security cultivated through the Human Development Reports: both are based upon discursive logics concerned with the individual, and advocate a development-based notion of security that can be secured through state and international actions. A central plank of the UNDP definition of human security is to ensure that 'the opportunities they have today are not totally lost tomorrow'.55 While there is a shared sense amongst activists that Serbia's multiple

\footnotetext{
s3 Interview, Sandglass activist, Kruševac, 3 July 2008.

${ }^{34}$ Interview, Jasmina Mitrović, activist, SOS for Women and Children, Valsotinice, 2 July 2008.

35 UND1 Human Security Report 1994: New Dimensions of Human Securiy (Oxford University Press, New York, 1994), p. 23.
} 
transitions from communism, war, and dictatorship has increased the insecurity of daily life, there are differences in how these insecurities are structured, notably in the critique of the politics of the state, and the extent to which these politics are configured as a consequence of war.

An activist from Women's Centre Obrenovački, "Andjela", felt that unemployment was a major cause of gender insecurity in Serbia, arguing that

'employed and unemployed women are not the same! We in Serbia know that well [This economic insecurity] is not a problem we faced a few years ago. First we had one regime, then we had another one, but in the last eight years there has been no progress. Our progress is so slow and this situation lasts too long'. ${ }^{56}$

Interwoven into this account is a frustration with the lack of positive change and real social stability. The lack of social stability arising out of the multiple transitions and regime changes of the past twenty years is pointed to as a cause of insecurity, as it is judged to result in an inability to plan, or a tendency to subconsciously prepare for the worst. Another activist, Jelena, felt that

'After the [NATO] bombing I cannot say what would be a secure situation for me, because you simply learn to live in different conditions... [If I was] a member of the EU, I could get the [certainty] that in the next few years my country would have certain kind of Government, certain laws, because here [in Serbia at the moment] you cannot "catch" the reality and say that's it... because here, we cannot plan our lives any longer than a week in advance, we can't think of loans, because if the radicals form the government, what will happen with foreign banks and our loans? So when I think about security, I don't even think about war, it is the least problematic for me'.57

Both accounts reflect a frustration with the progress of the state in achieving security within everyday life. Fears for futures are embedded in these accounts, arising out of an uncertainty based upon events in the past(s). However, different ways of framing these insecurities are woven into these narratives, a framing which is indicative of the gender politics held by activists.

For Andjela, there has been 'no progress in the last eight years': suggesting that the promises of a brighter future after the fall of the Milošević regime in October 2000 have been shattered by 2008 . Much research has explored the way that democratisation limits the possibilities for gender equality: Andjela's narrative can be heard across Serbia, and central and eastern Europe. ${ }^{58}$ However, when Andjela's position is contrasted with Jelena's, the differences in how gender politics configure a particular vision of gender security are illuminated. Jelena, who was speaking the day before the

\footnotetext{
56 Interview, Activist from Women's Centre Obrenovacki, 16 April 2008. Andjela is not her real name. All activists at Women's Centre Obrenovački asked for anonymity.

57 Interview, Jelena Visnjić, Coordinator, Voice of Difference, Belgrade, 10 May 2008.

58 B. Einhorn Cilizenship in an Enlarging Europe: From Dream to Awakening (Palgrave, Iondon, 2006).
} 
Serbian parliamentary elections in May 2008,59 points to specific structural changes that are needed, 'a certain kind of government' and membership of the EU are critical for achieving gender security in Serbia. Insecurity, for Jelena, is linked to the policies of the Serbian Radical Party ('the radicals': Srpska radikalna stranka, SRS), who are a far right ultra-nationalist party, led by Vojislav Šešelji, currently on trial for war crimes in The Hague. The SRS secured $23 \%$ and $29 \%$ of the votes in the 2003 and 2007 elections, and in 2008 fought on anti-EU membership platform. For Jelena, the promise of EU membership is not only the 'certainty' that Serbia would have a particular political profile, but that 'European laws and legislation will force our society to change', specifically in simulating Serbian society to face the past and accept political responsibility. ${ }^{60}$ That is, a future vision of postwar security for Jelena would mean that Serbian state and society has addressed nationalist perceptions and attitudes rooted in the past conflict.

A wide range of concerns about daily life affect how most activists signify insecurity: issues about unemployment, poverty, loss of social values, safety of their children and social stability all cluster around the discursive terrain of security. However, to underpin the variations in the discursive logics of security between various (groups of) individuals and organisations, we must once more return to the extent that war and nationalism frame these significations of security. Slavica Stojanović, the director of Reconstruction Women's Fund, argues that we should take care with the use of "everyday life", as everyday life appears to be a politically neutral phrase, and it can be used to camouflage deeper structural issues. ${ }^{61}$ This ontological perspective mirrors what critical security theorists argue: that by making the referent subject of security the state, particular (structural) violences are ignored. Certainly, amongst some feminists, there is a perception that structural factors affected by the processes and consequences of war and nationalism have affected the insecurity of day-to-day life: including unemployment, the affordability of health and social insurance, poverty, and the values held by society. While most activists felt that the insecurity of daily life has been shaped by the consequences of war and nationalism, some activists, like Jelena, pointed to deeper structural issues to explain the insecurity of daily life: that is, the political profile of government and the attitude taken towards Serbia's post-war problems, which serves to highlight the gender politics inscribed within "everyday" visions of in/security.

\footnotetext{
59 'This context is important. As previously stated, the election campaign was polarised between a "progressive" EU membership stance; or a position retaining Kosovo as part of Serbia and for closer cooperation with Russia. The coalition government that was formed in July 2008 insist that it is possible to pursue all of these stances, although it is widely believed in Serbia that it is not possible to achieve EU membership with Kosovo as part of Serbia.

60 Interview, Jelena Visnjić, Coordinator, Voice of Difference, Belgrade, 10 May 2008.

61 Interview, Slavica Stojanović, Coordinator, Reconstruction Women's Fund, Belgrade, 31 March 2009.
} 
Activists from feminist and women's NGOs in Serbia connected their understanding and interpretations of "gender security" to their personal experiences of insecurity. Insecurities between February - August 2008 typically included: a lack of freedom of expression or movement, femalespecific violence and inequalities, economic and political instability affecting "everyday life". These generalised, and claimed, significations of insecurities are framed in a particular way, revealing the political context arising from the personalised statement of insecurity. That is, the personal "sense" of insecurity (sometimes) becomes a normative political vision for what security ought to look like and how it can be achieved. As will be examined further in the following section, these visions about in/security relate to personal-political imaginations of war, conflict and post-conflict.

\section{TEMPORALITY AND (GENDER) SECURITY DISCOURSE}

The analysis of various significations of in/security indicate that the specific logics configuring perspectives on gender security have been shaped by a wide range of political attitudes about pasts, presents and futures related to conflict and post-conflict reconstruction. The discussion in the preceding paragraphs suggested that, generally, the "senses" of security and insecurity is the same amongst (most) activists, regardless of their political profile. What differentiates these senses of (in)security is the particular personal-political imagination shaping the ways in which (in)security is narrated, explained and envisaged. In other words, how activists problematise "post-conflict" affects the ways that "gender security" is framed. As a consequence, difference is crafted through personalpolitical imaginations of conflict and post-conflict, sometimes manifesting itself as a division within feminist and women's organising in Serbia. Jelena Visnjić, the coordinator of Voice of Difference, wondered;

'How we can be divided when this feminist non-solidarity costs us a lot. Then I understood that we are united when we share the same policies toward Kosovo, war crimes, institutions... and we are not united when we do not share the same policy..., what's dividing us? Nationalism.' ${ }^{2}$

Jelena suggests that shared set of values and policies relating to war, nationalism and conflict between groups promotes feminist unity. These values relating to war and nationalism also affect how "gender security" is framed. The final section of this chapter will focus upon the temporality embedded within these inscriptions of gender (in)security, highlighting the connections to the broad range of gender politics that are held by women and feminist activists in Serbia. The ways in which personal-political imaginations of conflict and post-conflict constitute the gender politics held will be unpacked to illuminate effects upon the framing of gender security.

62 Interview, Jelena Visnjić, Coordinator, Voice of Difference, Belgrade, 10 May 2008. 
Multiple versions, perceptions and memories of "the past" play a part in shaping significations of gender security. Two specific conceptualisations of "the past" are dominant. First, the "past" that is explicitly articulated by activists, a "past" that needs to be dealt with. This is best described as the political past, as it highlights a political position that emphasises the achievement of political responsibility, in particular the state taking responsibility for the Serbian war crimes committed during the 1990s. Women in Black is the most vocal feminist organisation dealing with this issue, but a number of individual activists and groups also share this position. The rhetoric of a past that needs to be dealt with is tied up with their hopes for the future: underpinning this political perspective is a belief that facing, and taking responsibility for the crimes of the past is crucial for Serbia's future social and political progress. ${ }^{63}$ Since a key objective of political responsibility is to expose the ideological justification of crimes - dismantling the political, social and cultural mechanisms conductive to war', many activists connected facing the past with achieving security. ${ }^{64}$ The second type of "past" playing a role in how security is signified is the past invoked as memory, as part of a narrative, as an experience that the interviewee believes has shaped the ways $s /$ he conceptualises security. Sometimes this is conveyed in an explict way, such as in talking about the NATO bombings of Serbia during 1999. Sometimes this past is invoked almost unwittingly, as when drawing on perceptions and beliefs about the relative security of "Yugoslavia" compared to "Serbia". These pasts are mediated through the present and hopes for the future, but simultaneously, the past shapes the present.

The impact of political values about the past, in particular the political responsibility agenda, upon the arrangement of security logics is especially apparent when looking at stories about the NATO bombing. For activists of Ženska Alternativa, in Sombor, northern Serbia, an NGO that focuses upon providing support to victims of domestic violence and achieving gender equality, the NATO bombings and economic problems of the 1990s affected how they felt about security because 'what didn't kill us made us stronger'. ${ }^{65}$ They told me that;

The life of all of us, of all the citizens became insecure, endangered in many ways. Poverty, crisis, the direct threat of war... mobilization of family members for war, unemployment... these have consequences for everyday things: Food, health, basic everyday life needs: all these were literally endangered... not to mention the psychological impact of absolute helplessness'. ${ }^{66}$

\footnotetext{
63 S. Zajović, Transitional Justice: A Feminist Approach (Women in Black, Belgrade, 2007).

Quotation from Zajovic, Trunsitional Justice, p. 9.

${ }^{65}$ Interview, Activist 5, Women's Altemative, Sombor, 20 May 2008.

ه Interview, Activist 2, Women's Alternative, Sombor, 20 May 2008.
} 
Similar discursive logics can be found within activists from Women's Centre Obrenovački, a group which aims to provide emotional and legal support to victims of domestic violence, based in a small town west of Belgrade;

'War [by which she means the NATO bombings] made us so strong, we are not actually afraid of anything, like animals. But they, British people, who have not had this experience for a long time, and I hope that they won't, they are more sensitive to those issues. We know what to expect, and we know that it cannot be worse than it was'. ${ }^{67}$

To some extent, both groups disassociate themselves in/explicitly from the feminist organisations or values that promote the political responsibility agenda. The NATO bombing is a cause of insecurity, but one which 'made them stronger'. There is no mention of violences in other parts of exYugoslavia.

In contrast, Ildiko Eredi, an activist in a women's group in Pančevo, near Belgrade, a group sharing many values with Women in Black, tells me that during the NATO bombings she had very young children, and when she 'heard the sound of sirens [indicating an imminent bombing raid] I told our children that it was bedtime, but it was not easy'. ${ }^{68}$ After a pause and a few moments of reflection, she told me how during the bombings, she 'constantly had in mind how people in Sarajevo [suffered during the 1992 - 4 siege]', and started her own 'personal responsibility campaign' where she rung people up and recalled stories of survival in Sarajevo in order to remind people 'now it's the time to remember, now its hard for us, but it's time to remember that we are not the only ones in the region who suffered. And that people coming from where we are now [in Serbia] provoked or caused suffering to other people in other parts [of ex-Yugoslavia]'.69 Ildiko's story, like that of many other political responsibility activists, compares her/his personal insecurity to others in the region.

The variations in how security is discursively constructed can be explained through how activists view the politics of the recent past. How war and nationalism is viewed affects the explanations behind in/security: while some women's organisations explicitly say that insecurity has 'nothing to do with nationalism', ${ }^{70}$ others say that 'nationalism is a product of [these] insecurities'.71 For those activists associated with the latter group, political responsibility is at the heart of achieving security because, as Slavica Stojanović, the coordinator of Reconstruction Women's Fund and a Women in Black activist

\footnotetext{
${ }^{67}$ Interview, Activist from Women's Centre Obrenovački, 16 April 2008.

68 Interview, Ildiko Jiredi, Coordinator, ZIMG, Pančevo (Belgrade), 5 May 2008.

69 Ibid.

7o Interview, Activist from Women's Centre Obrenovački, 16 April 2008.

71 Interview, Morjana Dokmanović, Intemational Gender Consultant, Subotica, 21 May 2008.
} 
concisely explained: 'the demilitarization of our mind is one of the most important parts of securitybuilding'.72 Facing the past and accepting political responsibility for the war crimes committed are important steps that need to be taken in order to achieve security in Serbia, as they are one of the key causal factors for the existence of these (in)security issues. While activists and organisations campaigning for political responsibility, antimilitarism and pacifism, point to war and nationalism as one of the causes of insecurity in Serbia, less politicised women's organisations rarely draw upon such connections. Political values shape the discursive construction of "security", and these significations are dependant upon how past(s), present(s) and future(s) are conceived. For more politicised groups, the "past" is political and has been constructed in such a way. Issues apparently located in the "past" need to be confronted and addressed for a more secure present and future. Less politicised groups see the past as something that is simply "there": it is not a temporal entity that can be altered. That is, the past has happened and it cannot be changed, and rethinking the past will not affect present or future (in)security.

These political perceptions about the past are located in the present (where the "present" is early 2008), and are indicative of contemporary social-political circumstances providing the context for the interviews that were conducted. The perception about the present (problems) of post-war reconstruction is an integral part of the personal-political imagination fashioning gender security discourse. Briefly turning to Cynthia Enloe's discussion of war museums, where 'every war museum is in fact a postwar museum... It portrays wartime experiences, but its design is based upon postwar memories, postwar worries', usefully illustrates the connections between wartime and post-war contexts. $^{73}$ Like museums, post-war memories and worries shape the political frameworks put forward about the past. Simultaneously, activist concerns, perceptions and worries about their presents profoundly shape the way they express their hopes and desires for the future. Through the very inscription of insecurity, activists explicitly or implicitly state how security can be made possible. Embedded within these hopes for future security, a particular conceptualisation of the direction of post-conflict reconstruction is alluded to: for example, activists discussed how the state accepting political responsibility or taking steps towards EU membership would increase their security.

While it is true that 'women come to understand themselves, their needs, and their relations with others and the state through their personal experiences of insecurity', there is also a need to

\footnotetext{
72 Interview, Slavica Stojanović, Coordinator, Reconstruction Women's Fund, Belgrade, 31 March 2009.

${ }^{73}$ C. Enloe The Curious Feminits: Searhing for W'omen in a New Age of Empire (University of Califomia Press, Berkeley, 2004$)$, p. 195.
} 
deliberately (re)signify gender security discourse if it is to be used successfully for political purposes. ${ }^{74}$ For instance, Adia Corović, the coordinator of Sanžack Women's Forum that aims to bring together women's organisations in southwest Serbia, has worked on projects concerned with gender security with Women in Black and Belgrade Fund for Political Excellence. ${ }^{75}$ Initially, she was a 'bit concerned' about using the concept of security, as she 'thought it was just defence of the country, military, NATO and that is the end of the story'. ${ }^{76}$ She then realised that 'security has a far broader context' and believes that 'women really have to give a new paradigm, they have to give a new face to the story about security,. ${ }^{77}$ Activists from women and feminist organisations around Serbia have drawn upon their experiences and hopes to make sense of what gender security could look like, and have conceptualised similar visions of security - in so far as most activists saw gender security to be a concept related to achieving human rights, addressing gender violence and concerns about everyday life.

The different articulations and representations of even the same signification related to "gender security" are product and productive of the personal-political imaginations of activists. That is, how the security concerns identified (freedom, gender violence and inequality, daily life) is framed relates to perceptions about conflict and post-conflict. These imaginations about the past, present and future are shaped by, firstly; the extent that activists have a space to reflect upon their experiences and visions: experiences and interpretations of conflict and post-conflict, and visions for gender security in Serbia's future. Secondly, the specific framing of a "sense" of "gender security" has been shaped by an understanding of how a configuration of gender security might fit into their political stances - and in particular, political stances about the state. Finally, the precise configuration of gender security rests upon how activists locate Serbia in relation to the past, present and future of conflict and post-conflict.

\section{CONCLUSIONS AND LOOKING AHEAD.}

Activists from feminist and women's organisations in Serbia view gender security in a multidimensional way. Claimed significations of (in)security included human rights, especially freedom of movement and political expression; gender inequality and gender violence; and

\footnotetext{
${ }^{4}$ T. Jacoby 'Firom the trenches: dilemmas of feminist IR fieldwork' B. A. Ackerly, M. Stern and J. True (eds.) Feminis/ Methodologies for Intermational Relation. (Cambridge University Pecss, Cambridge, 2006), p. 154.

75 Sanžack refers to a region in south-western Serbia, sandwiched in-between Kosovo and Montenegro. Belgrade Fund for Political Excellence (BFPE) is an organisation that runs education programmes aimed at politicians. During 2007 they ran a program dedicated to gender and security designed to acquaint publicly active women with security sector issues, in the spirit of UNSCR 1325. See www.bfpe.org (retrieved 13 May 2008). I discuss the work of BFPE more in the conculsions.

${ }^{76}$ Interview, Aida Corović, Coordinator, Women's Forum Saň̌ack, Novi Pazar, 12 July 2008.

$\pi$ Ibid.
} 
"everyday" concerns such as unemployment, lack of social stability, and the loss of social values. However, what this chapter has sought to illuminate is how gender politics are product and productive of the precise configuration of gender security amongst activists of feminist and women's organisations in Serbia. This has been done through investigating the temporality embedded within articulations of conflict and post-conflict inscribed in their gender security discourse. By exploring the narratives crafting the logics of gender security, it is clear that the discourse of security amongst activists of women's and feminist organisations in Serbia has been profoundly affected through their responses, perceptions, and attitudes towards war and peace. For those feminist organisations, including Women in Black, who are concerned with political responsibility and antimilitarism, the (re)signification of beqbednost is based upon opposition to a state-centric stance upon security. As will become clear in the following chapter, Women in Black have crafted a sense of gender security that echoes their long-held political stances: political stances reflecting particular perspectives about the pasts, presents and futures of Serbia in relation to conflict and post-conflict. These political stances form a narrative supporting a logic of gender security that seeks to deliberately produce a new "emancipatory" set of significations, posited in direct opposition to a (perceived) dominant statecentric security discourse. In other words, a group may articulate and represent gender security in a particular way in order to achieve their political hopes.

This chapter has sought to bring together several threads that make up part one of this study. Chapter one argued that the specific discursive configuration of "gender security" is formed through the personal-political imaginations of actors seeking to practice gender security. By illuminating the significant ontological logics supporting different configurations of security, chapter two demonstrated how "security" is a performative discourse, constituted through reiterative and citational practice that is dependant upon a range of signifiers to shape the performance of "security". Chapter three profiled the range of gender politics within feminist and women's organisations in Serbia, demonstrating that perceptions about war, conflict and the direction of post-conflict reconstruction shaped the political profile adapted by feminist and women's organisations and activists in Serbia. This chapter has drawn together these points to highlight that the inscriptions and configuration of "gender security", and in particular, the political framework and significance of these specific expressions of "gender security", is in part configured through personal-political imaginations of conflict and post-conflict. Ultimately, the first part of this thesis has illuminated the relationship between gender politics (understood as personal-political imaginations in relation to conflict and post-conflict) and the specific configuration of gender security discourse. 
Part two builds upon the broader picture of feminist and women's organising in "post-conflict" Serbia by investigating two in-depth case studies examining specific issue-areas or debates amongst feminist and women's activists in Serbia. The first case study, which is the focus of chapter five, is an examination of how gender security discourses have (re)shaped feminist-pacifist debate and action in Serbia. The second case study, in chapter six, highlights how gender security discourses have altered the domestic violence agenda in Serbia, by creating a particular set of circumstances simulating a greater concern with small arms and light weapon abuse in domestic violence. The case studies are intended as an illustration and further discussion of the theoretical and empirical arguments made in part one about the formation of competing logics of gender security: namely that the specific conceptualisation of gender security advanced by activists is product and productive of politicalpersonal imaginations about the past, present and future of war, conflict and post-conflict reconstruction in Serbia. These case studies demonstrate ways in which gender security discourse can be politically translated, and enables us to address questions about the political impacts of different configurations of gender security.

Both debates and agendas, as mentioned in the introduction, are in some way, responses to UNSCR 1325. UNSCR 1325 is a Security Council Resolution calling for the gender mainstreaming of all conflict and post-conflict processes. Through examining the discursive positioning, articulation and representation of UNSCR 1325 within each case study, the ways that gender security discourses are performed and utilised are revealed. UNSCR 1325 is ideal as a framework to guide this in-depth analysis as it is at the intersection between discourses about gender, and discourses about security. Each case study will be evaluated through the analytical strategies laid out in chapter one, with a particular concern with the temporality embedded within articulations and representations of gender security, as a means of revealing the personal-political imaginations that (re)produce a particular organisational logic shaping representations of gender security. The debate discussed in chapter five, the feminist-pacifist agenda in Serbia, is an example of an explicit response to the gender security frameworks established by UNSCR 1325 . In contrast, the case study discussed in chapter six, the domestic violence debate in Serbia, highlight the implicit effects of the gender security frameworks of UNSCR 1325. By focussing upon how NGOs within each issue-area has responded to UNSCR 1325 , some of the ways in which gender politics is product and productive of security discourse will be illuminated. The varying responses to UNSCR 1325 demonstrate the differing impacts that personal-political imaginations of conflict and post-conflict have affected the logics behind a particular articulation and representation of gender security. 
PART TWO

ARTICULATING AND REPRESENTATING "GENDER SECURITY”. 


\section{CHAPTER FIVE.}

\section{A NEW PATCHWORK SQUARE: FEMINISM, PEACE, AND SECURITY.}

Staša Zajović, the coordinator of Women in Black, a feminist-pacifist group in Serbia, believes that UNSCR 1325 could be used as 'a tool for developing a new kind of security'.' While many feminist and women's organisations worldwide have used UNSCR 1325 to support their work, Staša believes that many are 'recycling [the resolution] in a bureaucratic manner' which supports the human security approach put forward by the United Nations (UN).2 The UN approach to security, as discussed in chapter two, does not aim to challenge the dominance of state/national security. Women in Black argue that UNSCR 1325 can be used to support an alternative, radical vision of gender security that challenges the primacy of state security. While UNSCR 1325 primarily focuses upon the gender mainstreaming of the UN's peacekeeping and post-conflict processes, the resolution - if reconceptualised - could be a potentially 'productive force' for how gender and security are thought about. ${ }^{3}$ Using UNSCR 1325 as an analytical intersection between gender and security, this chapter investigates the perception that an alternative and critical vision of gender security can be articulated and represented. By focussing upon the feminist-pacifist debates in Serbia, this chapter will illustrate how gender security discourse has been (re)configured to support activities and/or policies in support of feminist-pacifism.

The spotlight is placed upon the Women in Black network in Serbia, a dynamic group of activists at the forefront of the feminist-pacifist position in Serbia. ${ }^{4}$ Since 2005, Women in Black have deliberately articulated and represented a configuration of UNSCR 1325 and gender security that echoes and supplements their long-held feminist-pacifist position. Illuminating the connections between Women in Black's feminist-pacifist stances and articulations and/or representations of

\footnotetext{
1 Interview. Staśa Zajović, Coordinator of Women in Black: Serbia, Belgrade, 18 Scptember 2009. In Einglish.

2 Ibid.

${ }^{3}$ L. J. Shepherd Gender, Violence and Security: Discourse as Practice (Zed Books, London, 2008), p. 8. Sce also Ifelen Kinsella in Cohn, C., Kinsella, H. and Gibbings, S. 'Women, Peace and Sccurity: Resolution 1325' Intemutional Feminist Journal of Politics, Vol. 6, No. 1, (2004) p. 136.

4 'Forefront' is deliberate: Women in Black was not, and is not, the only anti-war initiative in Serbia, but it is extremely vocal and wellknown for its feminist-pacifist stance.
} 
gender security highlights the importance of conflict and post-conflict imaginations in the configuration of "gender security". To examine how constructions of gender security have been product and productive of Women in Black's political profile, the chapter begins by outlining the discursive logics of the feminist-pacifist debate in Serbia. The patchwork blanket of values that make up Women in Black's political profile is heavily inscribed with critiques of militarism and has a particular emphasis upon political responsibility. Drawing out these elements of Women in Black's political profile supports judgements about how gender security discourse is performed in relation to the group's feminist-pacifist stance, as well as identifying when these representations of security are initially articulated.

Attention then turns to a consideration of how the personal-political imaginations of conflict and post-conflict held by Women in Black activists influenced the notions of gender security that activists developed. The specific logics of "gender security" put forward by Women in Black begun to be formulated through a series of Women, Peace and Democracy workshops during 2004/5. During these workshops, activists had a space to consider ways that gender security could be (re)signified in light of their experiences and beliefs, and the political opportunities offered by UNSCR 1325. The final section of this chapter investigates how Women in Black have utilised and exploited the possibilities of UNSCR 1325. The activities discussed illustrate how Women in Black activists have reconciled the resolution with their feminist-pacifist values by making a connection between (gender) peace and (gender) security. The gender politics of Women in Black centre on critiques of militarism and support for political responsibility: a politics emerging from personal-political imaginations of conflict and post-conflict. Activists have utilised UNSCR 1325 to put forward an alternative vision of gender security. The articulation and representation of a gender security discourse resting upon structural logics of antimilitarism is crafted as a new patchwork square for the group's feminist-pacifist stance.

\section{WOMEN IN BLACK AND THE FEMINIST PACIFIST DEBATE.}

As stated in chapter three, Women in Black is a transnational peace network connected by ideas of feminism, peace, and peaceful protest, with local groups pursuing their own visions and agendas. ${ }^{5}$ Women in Black - Belgrade formed in October 1991, in the midst of a nationalist civil war, and so activists based their visions and agendas upon their understandings of the gendered mechanisms behind war and nationalism. Although personal understandings of feminism, antimilitarism and antinationalism vary, and not all Women in Black activists hold the same position, a generalised

${ }^{5}$ C. Cockbum From When Wi Stand. War, Women's Activism and Feminist Anatysis (Zed Books, London, 2007), pp.48 - 53. 
overview can be reached from their publicised perspectives. ${ }^{6}$ The group has articulated their collective vision of feminist-pacifism through publications, workshops, seminars and street actions. ${ }^{7}$ One reason for the wide range of perspectives is that the Women in Black network is an association of several groups and individuals dotted around Serbia. The national network has its origins in the Belgrade group, and so other feminist-pacifist groups around Serbia are connected to Women in Black - Belgrade. When "Women in Black" is mentioned in this chapter, it refers to the network of groups and activists that form the Women in Black network in Serbia, even if the particular group is not named "Women in Black".

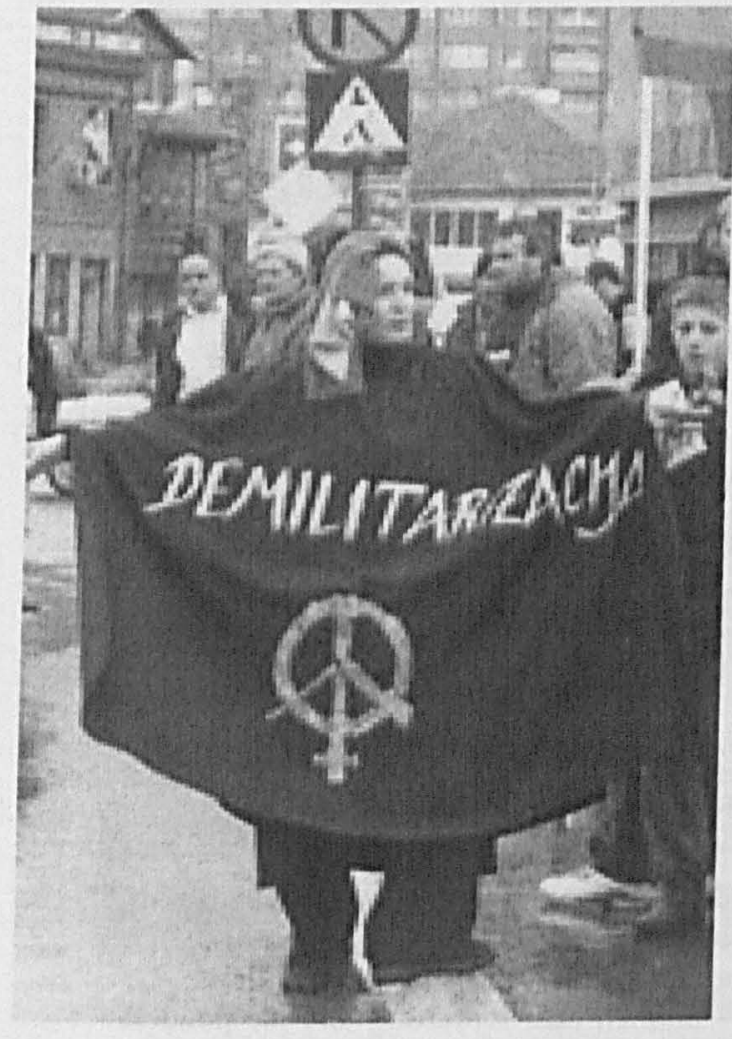

Image 5.1: Women in Black activist holding a banner marked demilitarizujumo (antimilitarisation) during a protest. Retrieved from htep:///zeneucrnom.org [accessed 10 June '2010].
One Women in Black activist, Adriana Zaharijević, argued that the group's values has evolved through experience, like a 'patchwork method'. ${ }^{8}$ The metaphor provokes an image of several viewpoints connected as a coherent blanket, and suggests that it is possible to add more squares and ideas. In terms of an NGO, values refer to the publically stated beliefs of the organisation, underpinning the campaigns conducted. Since Women in Black have expounded activist energies upon addressing the tensions between feminism and pacifism, the group's values are a highly considered set of beliefs.? "Security" as a value was first explicitly articulated by Women in Black in 2005, but the specific conceptualisation of "security" links to the discursive logics that underpin the group's long-held feminist-pacifist values. Discursive logics refer to the arrangement of signifiers clustering around the

\footnotetext{
${ }^{6}$ Cockburn discusses the divergences in visions of pacifism in From wher we Stand, pp. 181 - 192. See also L. Mladjenovic 'Feminist Politics in the Anti-war movement in Belgrade: To Shoot or Not To Shoot?' in W. Giles, A. de Alwis, E. Klein and N. Silva Feminists Under Fire: Exchanges across War Zone (Between the Lines, Toronto, 2003), pp. 157 - 166

${ }^{7}$ Much of the analysis in the following paragraphs is based upon a collection of twelve Women in Black, Women for Peace publications that summerise the group's recent activities by collating seminar and workshop reports, reprinting press releases or leaflets handed out in the street, and reflections or short essays from activists. All are published by Women in Black, Belgrade, and are available in Serbian: most are also translated into English. Unless cited otherwise, all Women in Black sources have been translated by Women in Black from Serbian into English.
}

${ }^{8}$ M. Perkovic, 'From Rebellion to Alternatives' in Women in Black Women for Peace (Belgrade, 2007), p. 24.

${ }^{9}$ For instance, workshops reflecting upon the values of the group are held on a regular basis. The author participated in one such workshop: 5-7 June 2009. Women in Black network action and meeting on antimilitarism, Kukaviča, Leskovac. 
articulation and representation of a discourse. Examining the discursive logics of Women in Black's feminist-pacifist discourse reveals that the same logics underpin their security discourse. This section outlines the discursive logics of Women in Black's feminist-pacifist stances, focussing upon the group's critiques of militarism and support for the political responsibility project. Attention will then move to an analysis of connections between Women in Black's feminist-pacifist stance and their interpretation of "security". Through highlighting the discursive logics underpinning the values articulated by Women in Black, it is possible to ascertain how security discourse has been woven into their patchwork blanket of values.

\section{Critiques of Militarism.}

For Women in Black, to be feminist is to be antimilitarist. ${ }^{10}$ Militarisation is best understood as a pervasive process 'by which a person or thing gradually comes to be controlled by the military or comes to depend for its well-being on militaristic ideas'." Individuals and/or society "come to imagine military needs and militaristic presumptions to be not only valuable but also normal'.12 Women in Black oppose, resist and challenge what they identify as processes of militarism through a variety of actions and campaigns. This critique of militarism is central to their feminist-pacifist stance, as implied by photograph 5.1 (above, left). The image shows an activist wearing a banner painted with "demilitarisation" and a logo merging the female and peace symbols; suggesting that her antimilitarist position is connected with her feminist and pacifist values. For Women in Black, militarism is associated with a range of structural, institutional and social practices:

The institutional manifestations of the growing militarization are the increasing number of (regular and paramilitary) units, the enormous military budget, the wartime economy... the promotion of militaristic values, symbols and language, necrophilia, mystification of death, the strict division into female and male roles (women $=$ mother; $\operatorname{man}=$ warrior) and the political marginalization of women are its ideological manifestations.' ${ }^{13}$

Women in Black identify militarism as a structural process infusing social, political and economic life, specifically highlighting the consequences of militarism upon gender roles.

Woven through Women in Black's critique of militarism is a standpoint perception about patriarchy, which notices how day-to-day gender experiences are shaped by state actions and structures. Since

\footnotetext{
${ }^{10}$ Staša Zajović and Boban Stojanović 5-7 June 2009, speaking at the Women in Black network action and meeting on antimilitarism, Kukaviča, Leskovac. Author's notes from participant observation.

" C. Enloe Maneutres: The Intermational Politics of Militarqing Women's Lives (University of California Press, Berkelcy, 2000), p. 3.

12 Ibid.

13 Women in Black, Women for Peace (Women in Black, Belgrade, 1994) p. 31.
} 
militarism is a process embedded in society, the consequences of militarism continue even after the declaration of peace. Following the Dayton Peace Agreement in 1995, which signalled the official end of war in Bosnia-Herzegovina, Women in Black stated that,

'those of us who live in this region know that the war continues. The environment in which we live is permeated with the practice and logic of war and militarism... this is carried out with the state's nationalistic-militaristic ideology and propaganda, so that women endure patriarchal violence in both the public and private spheres..14

The discourse of Women in Black stresses a casual connection between militarism and all types of violence against women. ${ }^{15}$ This connection is made apparent through personal experiences of living in a militarised society. Militarism's impact upon structural patriarchy also mould gender expectations: National-militarists demand the transformation of the maternity wards into recruitment centres... to bear and wage war are [sit] to be the main occupations of Serbian women and men'16 That is, militarisation which deeply permeates society places heightened expectations upon women to fulfil "traditional" reproductive and nurturing roles to ultimately provide sons to fight for the nation. ${ }^{17}$ For Women in Black, the consequences of militarism also entwine with nationalism: militarism supports the reliance upon nationalist instrumentalism of "traditional" gender roles, or the nationalistic culture of violence perpetuating violence against women. Ultimately, Women in Black critique militarism for its consequences upon patriarchal gender roles that support the reproduction of nationalism.

Women in Black take action against processes of militarism by putting forward radical challenges to the militaristic values embedded in society. ${ }^{18}$ Changing social values has been a central ambition from the start: a leaflet distributed at the first Women in Black protest on 9 October 1991 says that:

We Women in Black wish to stimulate different values than those dominated by the patriarchal spirits which are imposed upon us: non-violence in place of violence, solidarity instead of oppression, life instead of destruction, necrophilia and death'. ${ }^{19}$

\footnotetext{
14 Women in Black (Ncwsletter. June 1996). Cited in Enloe Manewters p. 147.

15 Enloe Manewters pp. 147-9.

${ }^{16}$ Women in Black (leaflet) 'Announcement: Militarism, Nationalism and Sexism always go Together' Belgrade 18 january 1995, published in Women For Peace (Women in Black, Belgrade, 1995), p. 19.

${ }^{17}$ See also Žarana Papić 'Women in Serbia: Post-Communism, War, and Nationalist Mutations' S.Ramet (ed.) Gencer Politics in the W'estern Balkans: Women and Sociefy in Yugaslavia and the Yuguslav Suctessor Siates (Penn State Press, Pennsylvania, 1990), pp. $160-165$ and S. Zajovic

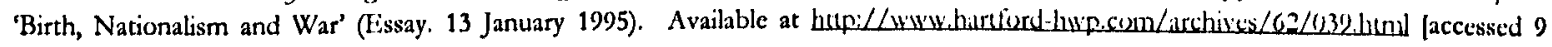
August 2010].

18. Zajović Aluags Disobedient (Women in Black, Bclgrade, 2007), p7.

${ }^{19}$ Women in Black 'Women in Black Against War' (Leaflet. 9 October 1991) Women For Peace Anthology (Women in Black, Belgrade, 1993), p. 22.
} 
To challenge the militaristic values imposed upon us', Women in Black activists choose to be feminist-pacifists. That is, a political and ideological choice has been made to become pacifists, rebuffing traditional 'social roles of women as martyrs and victims'.20 Women in Black present a challenge to images of women as Beautiful Souls or Maternal Thinkers - both constructions of passivematernalpeacelovers. ${ }^{21}$ These constructions of passivematernalpeacelovers are fraught with pitfalls for many Women in Black activists since existing patriarchal perspectives about women and peace based on maternal images of women are left unchallenged. Taking the perspective that pacifism is a political choice emphasises the political agency of activists in challenging existing patriarchal images of maternal peacekeepers. ${ }^{22}$ The emphasis upon political agency complements activist hopes of transforming the patriarchal foundations of society: through claiming a choice to be feministpacifists, activists challenge existing social values.

Central to Women in Black's critique of militarism is an understanding of the grip militaristic values have upon society, a grip which appears to shut down alternatives. For Women in Black, since militarism is a process deeply embedded in society, many activists feel that 'more than a decade of nationalistic and militaristic ideology and praxis has taken away the possibility of choice'.23 As such, voicing an alternative to militarism is an essential part of their critique of militarism. These alternatives emphasise the importance of reshaping social values, including 'demilitarisation of the mind, to influence the change of the patriarchal mentality.'.24 Presentation of alternative values that challenge the dominant militaristic values is a key theme of many campaigns and actions taken by Women in Black. For example, the group's 'Everything for Peace, Health and Knowledge - Nothing for Armament' activities criticise state spending on armaments, highlighting how funds could be diverted towards education and health. ${ }^{25}$ Through raising questions about state spending on

\footnotetext{
20 Quotation retrieved from Women in Black 'Proclamation on the second anniversary of Women in Black' (Leaflct. October 7 1993), Women in Black, Women for Peur (1994), p. 17. See also Women in Black 'Women in Black against war' (Leaflet. 10 June 1992), Women for Peuce (1993), p. 50 .

21 Cynthia Enloe runs words together to highlight well-trodden gender constructions: see lootpillageandrape' Maneuvers, p. 132. J. B. Elshtain W'omen and War (University of Chicago Press, Chicago,1995), pp. 140-9 discusses the representation of Hegelian Beautiful Souls; S. Ruddick Matemal Thinking: Towards a Politics of Peace (The Women's Press, London, 1989) argucs that women's socially constructed caring role provides a basis for resistance to militarism. C. Sylvester, 'Riding the Hyphens of Feminism, Peace, and Place in Four- (or Morc) Part Cacophony' Allematives, Vol. 18, (1993) pp. $109-118$ provides an overview of the various representations of women and peace.

22 Since pacifism is a political choice, men are able to join a feminist organisation rejecting militarism. See comments made by Bojan Aleksov during the workshop 'Is there a specifically Female Pacifism?' published in Women in Black, Women for Peace (Belgrade, 1994), Pp. $130-132$ and Cockbum Firom whene Stand, pp. $220-221$.

${ }^{23}$ Women in Black 'Meeting of Conscientious Objectors' (Workshop proceedings May 5 - 7 2000) published in Women for Peace (Women in Black, Belgrade, 2001), pp. 241 - 2.

${ }^{24} \mathrm{lbid}$

2s Zajović Aluryss Disobedient, p51. Women in Black network action and meeting on antimilitarism, Kukaviča, Leskovac. Author's notes from participant observation 5 June 2009.
} 
armaments, and presenting alternatives to militarism, Women in Black aim to dismantle the dominance of militarism.

These critiques of militarism shape how Women in Black activists consider war and their postconflict context. A feminist standpoint perspective that emphasises personal experience supports an ontology viewing militarism as a structural process which is embedded in society. Critically, activists recognise militarism as a process supporting patriarchal structures. By pushing for an alternative set of values, it is possible to challenge the grip of militarism upon society. As will become clear over the course of this chapter, the articulation and representation of gender security put forward by Women in Black recalls similar discursive logics as their critiques of militarism.

\section{Political Responsibility: The Postwar Problem.}

A key slogan articulated by Women in Black's is Not in Our Name', which is intended to convey criticisms about the policies of the Serbian state in relation to the wars during the 1990s. For activists, the statement Not in Our Name' summarises a,

'relentless, public, blatant and vociferous distancing from those who speak in our name, who wage wars or tesort to violence; unless we do this, they might think that they have our consent, our approval and even our complicity in atrocities. ${ }^{26}$

In short, Not in Our Name' is indicative of Women in Black's opposition to the war crimes committed by the Serbian state during the 1990 s. For Women in Black, to address the problems of war, conflict and militarism in the post-conflict era, there is a need for Serbian state and society to face the past and accept political responsibility. As discussed in chapters three and four, the extent of engagement with issues surrounding political responsibility plays a part in shaping the profile of gender politics adapted by feminist and women's organisations in Serbia. For Women in Black, 'confronting the past and transitional justice are among (sic) the most important segments of the peace policy'. ${ }^{27}$ The focus of the discussion here is upon how political responsibility is represented as a key element of Women in Black's feminist-pacifist position.

\footnotetext{
${ }^{26} \mathrm{~S}$. Zajović Not in Our Namel' (I'alk given at 'Women, Pcace, Security' confurence $1-3$ September 2006, Struga, Macedonia) published in Women in Black Women For Peace (Women in Black, Belgrade, 2007), p. 73.

${ }^{27}$ S. Zajović Transitiomal Justice: A Feminist Approach (Women in Black, Belgrade, 2007), p. 61.
} 
The issue of political responsibility remains a sensitive and controversial social and political topic in Serbia. 28 The concept of responsibility derives from debates in post-World War II Germany about how to manage the legacy of National Socialism and the Holocaust. ${ }^{29}$ Within the Serbian context, the central question in relation to political responsibility is the extent to which the Serbian state and society is responsible for war crimes committed during the 1990s. These war crimes include the massacre at Srebrenica, where approximately 7000 Bosnian Muslim men and boys went missing, presumed executed, after the Srebrenica enclave, in northern Bosnia, fell to Bosnian Serb forces in July 1995. As it is thought that around $50 \%$ of the Serbian population deny or question the circumstances surrounding Srebrenica, Women in Black devote energies to raising awareness of Srebrenica, and other war crimes. ${ }^{30}$ Through visiting sites where war crimes are thought to have been committed, public actions designed to commemorate the anniversaries of the crimes committed, monitoring the war crimes tribunals, and making public testimonies about the crimes, Women in Black aim to raise public awareness of the crimes committed and place questions about responsibility high on the political agenda. ${ }^{31}$

For Women in Black, political responsibility is a necessary project in order to address the pervasive effects of militarism. Between November 1996 and March 1997, there were widespread public protests following Miloševićs annulment of local election results in parts of Serbia, known as the Belgrade Protests. ${ }^{32}$ The Belgrade Protests can be viewed as a tentative step towards democratisation in Serbia. ${ }^{33}$ In response to these events, Women in Black stated that:

"The long period of nationalistic euphoria and warmongering propaganda... have left farreaching consequences in the already deep-rooted patriarchal mentality in this area. It is our hope

2a O. Fridman 'Altemative Voices in Public Urban Space: Serbia's Women in Black' Etbnologia Bulkanica, Vol. 10, (2006) pp. 201 - 303; D. Duhaček 'The Making of Political Responsibility: Hannah Arendt and/in the case of Serbia' J. Lukić, J. Regulska and D. Zaviršck (cds.) Women and Citizenship in Central and Easterm Eumope (Ashgate, Aldershot, 2006) pp. 205 - 21 2006; J. Obradović-Wochnik 'Knowledge, Acknowledgement and Denial in Serbia's Responses to the Stebrenica Massacre' Joumal of Contemporary Eunopean Siudies, Vol. 17, No. 1 (2009), pp. $61-63$.

${ }^{29}$ Duhaček 'The Making of Political Responsibility', pp. 207-12.

3o Statistic from Belgrade Human Rights Centre and Strategic Marketing, 2005, cited in Obradović-Wochnik 'Knowledge, Acknowledgement and Denial', p. 62. As indicated in the introduction, accurate figures are difficult to obtain, and that such surveys oversimplify the dynamics of denial, but they are useful in demonstrating that a significant proportion of the Serbian population do not acknowledge that war crimes were committed by the Serbian state.

31 Details of actions taken by Women in Black in telation to transitional justice are published in Zajović Transitional Justize, pp. 64 - 83.

32 See M. Blagojević 'Belgrade Protests 1996/1997: From Women in the Movement to Women's Movement?'. Lukić, J. Regulska and D. Zaviršek (eds.) Women and Ciližnship in Central and Easlem Eumpe (Ashgate, Aldershot, 2006), pp. 147 - 150 for an overview of the ambitions and strategies of the $1996 / 7$ protests.

33 Blagojević 'Belgrade Protests 1296/1997', p. 147 
that a process of decontamination from an authoritarian and nationalistic conscience is underway, but it is bound to be very lengthy'. ${ }^{3+}$

A central priority for Women in Black during the Belgrade Protests was to remind people of their moral responsibility for the war crimes committed. ${ }^{35}$ For Women in Black, taking responsibility for the war crimes committed during the long period of nationalistic euphoria and warmongering propaganda' was critical for successful post-war reconstruction and democratisation in Serbia. Woven through the group's discourse is the perception that addressing political responsibility is part of the process of dismantling the grip of militarism and militaristic values in Serbia. For activists, the political responsibility project is critical to crafting a feminist-pacifist discourse which challenges what activists identify as deeply embedded militaristic structures and processes within Serbian society.

The values supporting processes of militarism and structures enabling the evasion and denial of political responsibility are identified by Women in Black activists as deeply patriarchal. For Women in Black, recognising the gender dimension of the political responsibility project means 'valuing women's non-violent resistance'; 'strengthening women's autonomy through their active involvement in peace-building' and peacekeeping; and 'building women's coalitions as an active peace policy', ${ }^{36}$ The epistemological emphasis upon women's experience is used as a response to a critique that the peacekeeping and post-conflict process in Serbia has focussed upon male knowledge. Achievement of genuine political responsibility means incorporating the experiences and knowledge of women. To deal with the patriarchal structures that separate and oppress female experience, Women in Black initiate public acts of resistance to all patriarchal structures that decide in our name and wage wars and conduct acts of violence in our name'. ${ }^{37}$ Women in Black resist the patriarchal structures they identify in social and political life by highlighting ways that female experiences and involvement can count towards successful execution of the political responsibility project.

The discursive logics of Women in Black's feminist-pacifist position, in both their critiques of militarism and insistence upon the political responsibility project, reflect a standpoint feminist ontology and epistemology that has 'an explicitly critical understanding of the state as a set of patriarchal practices that support, yet silence, the structural disadvantages that women face'. ${ }^{38}$

\footnotetext{
${ }^{34}$ Women in Black (leaflet) 'We Shall Remain in The Strects of Belgrade' 4 March 1997 published in Women lior Peure (Women in Black, Belgrade, 1997), p. 24.

35 Ibid., p. 25.

36 Zajović Aluags Disobedient, p. 37; Thansitional Justice, pp. 62-3.

"Zajović Trunsitional Justice, p. 63.

${ }^{38}$ L. Hansen 'Ontologies, Epistemologies, Methodologies' L. J. Shepherd (ed.) Gender Mutters in Glabal Politics; A Feminist Intruduction to Intemational Relations (Routledge, I.ondon, 2010), p. 21.
} 
Underpinning this particular understanding of patriarchy is an ontology that emphasises institutional and social structures that embed particular values and processes within social and political life in Serbia. Institutional and social structures support processes that reinforce militaristic values, including the evasion of political responsibility. In sum, the discursive logics that surround Women in Black's feminist-pacifist stances focus upon a critical understanding of patriarchy; knowledge derived from female experiences; an emphasis upon understanding how structures and processes institutionalise particular values; and finally, calling for the implementation of alternative values. Together, these foundationalist assumptions guide and reinforce a conceptualisation of feministpacifism posited as a critical alternative to the perceived dominant, militaristic, state values.

\section{The Patchwork Blanket: Adding "Security".}

These discursive logics surrounding their feminist-pacifist position are indicative of the gender politics put forward by Women in Black. Questions remain regarding the way the gender politics of the group shape the security discourse articulated and represented, and the connection made by Women in Black between their security discourse and UNSCR 1325. The rest of this chapter investigates the connections between Women in Black's long-held feminist-pacifist position and their security discourse, taking UNSCR 1325 as the intersection between discourses of gender and discourses of security. The feminist-pacifist position articulated by Women in Black activists is highly considered. In a documentary about Women in Black, activist Slavica Stonjanović described how international visitors during the 1990 s were amazed that activists took the time for reflection. ${ }^{39}$ Reflection upon their positions was important because activists 'were driven by the need for new understanding and information'.40 As an organisation, activists sought to make sense of their heritage and circumstances in order to reach understandings and explanations of events around them, and of their own values and perspectives. These personal-political positions, formed through individual and collective reflections, shape how security discourse became incorporated into the group's patchwork blanket of feminist-pacifist values.

A brief discussion about meanings of feminist anti-militarist security and UNSCR 1325 took place at a workshop in May 2004.41 However, documentary analysis suggests that security was not explicitly articulated as a key value of Women in Black until 2005; which is around the same time that UNSCR

\footnotetext{
39 Film documentary 'Women in Black 15 years on' Made by Women in Black, 2006. The film can be vicwed on You'Tube, with Einglish

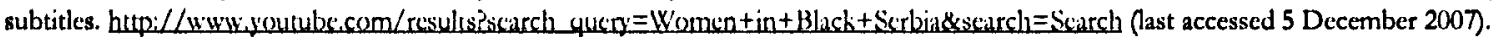

40 Ibid.

41 Women in Black 'Everything for Peace, Health and Knowledge, Nothing for Armament', (Workshop Proceedings May 2004), published in Women For Peare (Women in Black, Belgrade, 2005), pp. $340-1$ and $344-47$.
} 
1325 became one of the strategies deployed by the group to achieve their objectives. Although the fundamental values of Women in Black have not changed, "security" has gained conceptual popularity, and as a consequence, the concept has become more explicitly mentioned. This is a point acknowledged by Staśa Zajović, the coordinator of Women in Black in Serbia, who states that

'Although only in recent years has the issue of security received our special attention, our feminist-antimilitarist actions have always challenged the traditional militarised understanding of security'.42

Returning to the idea of a patchwork blanket of political beliefs, a particular conceptralisation of security has been sewn into the blanket of values held by Women in Black. The conceptualisation of gender security put forward by Women in Black from 2005 reinforces their critique of militarism and insistence upon political responsibility.

The gender security discourse utilised by Women in Black is framed in a critical standpoint feminist way, like their feminist-pacifist discourse. The group's articulations of security reject traditional notions of militarised and armed state security and argue for a shift to human security where women are visible. ${ }^{43}$ Additionally, security,

is not about borders; [and is not] achieved with weapons. Just and lasting peace is the basis of security and it can only be achieved through creating a society in which all causes of war including nationalism, patriarchy and exploitive economic systems - are eliminated'. ${ }^{\prime 4}$

This vision of security emphasises making women visible, critiquing social, political and economic structures that are seen to cause patriarchy and war, and insisting upon alternative values. The conceptualisation of security put forward by Women in Black echoes the discursive logics of their feminist-pacifist position. Furthermore, the group's gender security discourse serves to reinforce their feminist-pacifist position. That is, Women in Black draw upon a conceptualisation of gender security that is product and productive of their feminist-pacifist values. This connection between pacifism and security is possible because both concepts are understood through shared foundationalist assumptions made from a feminist standpoint critique. Since "peace" and "security" can share similar discursive logics, it is possible for Women in Black to incorporate "security" into their feminist-pacifist patchwork blanket of values.

\footnotetext{
${ }^{42}$ Zajović Aluxyys Disubedient, p. 49.

${ }^{43} \mathrm{~S}$. Zajovic, 'Peace and Security from a Feminist-Pacifist Perspective' in Women in Black W'omen for Peace (Women in Black, Belgraule, 2008), pp. 179- 80 .

4 J. Vukovic 'Security, The activities of Women in Black, and UN Security Council Resolution 1325' in Women in Black W'omen for Peace (Women in Black, Belgradc, 2008), p. 183.
} 
The previous paragraphs indicate that Women in Black have deployed a notion of "gender security" that supports their long-held feminist-antimilitarist principles. Discursive logics that critique social and political structures, insist upon making women visible, and call for a change in social, political and economic values are deployed to offer an alternative vision of "gender security". This vision of security is posited in opposition to "dominant" state security approaches. In chapter two, a case was made for conceptualising "security" as a performative discourse, exposing the metatheoretical assumptions underpinning security discourse. This section has demonstrated that the metatheoretical assumptions shaping Women in Black's security discourse is similar to and connected to their longheld feminist-pacifist position. Women in Black have reconfigured gender security discourse to support their feminist-pacifist debates, activities or policies. The discursive logics underpinning the group's feminist-pacifist position forms part of the knowledge framework shaping the contemporary articulations and representations of gender security. Later in this chapter, activities relating to UNSCR 1325 are explored to reveal how articulations and representations of "gender security" echo and support Women in Black's feminist-pacifist position. Examining the discursive logics that form the foundation of Women in Black's feminist-pacifist values reveals how their vision of gender security is product, and productive, of these feminist-pacifist values.

\section{LEARNING ABOUT/THROUGH “SECURITY” AND UNSCR 1325.}

Gender security - like all concepts - requires thought about how it will be articulated and represented. The previous section highlighted that the concept of gender security put forward by Women in Black has clear connections to their long-held discursive and ideological logics of feminist-pacifism. Attention now needs to be paid to the dynamics involved in learning about, and considering gender security, to make sense of how activists identify and utilise political opportunities. Political opportunities in relation to gender security are made possible (and limited) by UNSCR 1325, the Security Council resolution on Women, Peace and Security passed in October 2000. This section demonstrates how Women in Black activists contemplated and learnt about gender security and UNSCR 1325, reflecting upon the role played by international donors and institutions in shaping a context within which frameworks of "gender security" operate. The analysis highlights the importance of a space, or a 'room of one's own' to understand and think through how concepts and institutions are, and have been, constituted. 'This 'room of one's own' not only supports identification of possible political opportunities, but ensures that the specific vision of gender security put forward is reflective of Women in Black's feminist antimilitarist stances. 


\section{'A Room of One's Own': Developing Notions of "Security".}

UNSCR 1325 was a resolution designed to act as an intervention in the functioning of the UN, to promote gender awareness and gender mainstreaming. Despite the resolution not being intended as an advocacy tool, 'women's NGOs in conflict zones have used it multiple strategic ways', 45 Before NGOs can use the document to support their agency, a space is needed for reflection upon and learning about the concept of "security", a concept embedded within UNSCR 1325. The ways in which particular concepts are framed and thought about impacts upon our actions and responses: (re)assessing the way these concepts are constituted could have a significant impact on how UNSCR 1325 can be applied.46 Many civil society leaders, including Aida Corović, a Woman in Black activist in Novi Pazar, point to the need to educate about, and localise, topics and concepts before it can be meaningful and useful for women. ${ }^{47}$ Physical and mental space to reflect upon the meanings and possibilities embedded within the discursive terrain of security discourse and UNSCR 1325 is crucial. In interviews, it was apparent that activists involved with Women in Black were more confident about how "security" related to their interests and concerns, in comparison with other activists interviewed. In part, this is because Women in Black had much of the space required for reflection during a year long educational project held during 2005 titled Women, Peace, and Democracy, supported by UN Trust Fund money. ${ }^{48}$

Feminist commentators have long recognised the importance of 'a room of one's own' to learn, form ideas, to write, or to make changes. ${ }^{49}$ A space created through discussions held as part of the Women, Peace, and Democracy workshops enabled Women in Black activists to have the opportunity to consider meanings of security and to explore prospects opened up by UNSCR 1325.50 In seminars, activists explored feminist-antimilitarist ways of conceiving of "security", and linked their perceptions and visions of (in)security to personal-political imaginations of conflict and post-conflict. Nadja Duhaček, an activist who led some of the workshop sessions, felt that most women connected

\footnotetext{
45 C. Cohn 'Mainstreaming Gender in UN Security Policy: A Path to Political Transformation?' in S. M. Rai and G. Waylen (eds.) Globul Gatemunce: Feminitr Perppectites (Palgrave, London, 2008), p. 189.'

${ }^{46}$ Shepherd Gender, Violence and Security, p. 9.

47 Interview. Aida Corović, Coordinator, Sandzak Women's Forum, Novi Pazar, 12 July 2008.

40 Vuković 'Security, The activities of Women in Black, and UN Security Council Resolution 1.325', p. 185.

49 Famously, V. Woolf $A$ Room of One's Own (Bloomsbury Classics, London, 1993). See also C. Enloe 'Teminists Thinking About War, Militarism, and Peace' in (cds.) B. Hess and M. Marx-Ferrec Anubzing Gender. A H landbouk of Sacial Science Reseurb (SAGL, Newbury Park, 1987), p. 526 and J. A. Tickner 'On The Frontlines or Sidelines of Knowledge and Power?' Intermational Simdies Retrew Vol. 8, No. 3 (2006), pp. 386 - 388. For a discussion of how NGOs can create room for changes, see the Kvinna Till Kvinna report To Make Room for Changes: Peace Sirategies from W'omen's Organisutions in Bosnia and Herzegotina (Kvinna Till Kvinna, Stockholm, 2006).

5) UNIFEM A Lije Free of Violence Is Our Rjght! The UN Trust Find to Eind V'iolene Against Women 10 Years of Intestment, p. 34, UNIFEM Country profile: Republic of Serbia (UNIFEM Regional Programme for Central and South-IEastern Europe) bup://uwiviunifumsk [accessed 26 May 2009]. Zajović Alukys Disobedient, pp. 51-3 outlines all the scminars and topics covered.
} 
in/security primarily with economic factors first, such as unemployment, lack of income and an inability to make concrete plans for the future due to economic instability. ${ }^{51}$ For many. Women in Black activists, this economic situation is a consequence of conflict and militarisation. ${ }^{22}$ These personal economic experiences become profoundly political through problematisations framed by perceptions about the present reality of "post-conflict" and future hopes for "post-conflict reconstruction". For Women in Black activists, the Women, Peace and Democracy workshops provided a space for reflection upon personal-political perspectives about conflict and post-conflict, and how these perspectives might interlock with notions about gender security.

Personal experiences are crucial in forming understandings of what "security" could mean. For example; Nada Dabić, the coordinator of Esperanca, a feminist pacifist organisation in Novi Sad with strong links to Belgrade Women in Black, stresses that by security, she does not mean
'only my physical security, I need my psychological security. If we do not have a mutual language, if we have different opinions, that doesn't give me the right to come and harass your family, or for you to harass mine. That doesn't give me the right to fire you. That doesn't give me the right to psychologically rape you each day through the media', ${ }^{53}$

Nada's response has clearly been shaped by her experiences. An hour or so earlier in the interview, she jokingly describes herself as the 'third victim of Slobodan Milošević' partly because she was fired from her job in January 1988 for publicly criticising Milošević's policies: her description of what "security" means includes a reference to job security. ${ }^{54}$ Her mention of the need to accept multiple languages may have been shaped by her experience of living in Novi Sad, the largest city in Vojvodina, an autonomous province in the north of Serbia with 27 recognised nationalities and six official languages. 55 The remark that the media should not 'psychologically rape you each day' may refer to the way certain sections of the Serbian media have, and continue to, utilise(d) rhetoric of nationalist hatred and reproduce violent constructions, causing insecurity for individuals, especially human rights defenders. The media have endangered individuals in Serbia in many ways, from demonising gay rights activists to the phenomenon of "post-TV news" violence in the early 1990s, where women suffered domestic violence after their partners watched violent images on the news. ${ }^{56}$ Nada's views of what makes her, and people around her, insecure shapes her definition of what

\footnotetext{
\$1 Interview. Nadja Duhačck, Women in Black activist, Belgrade, 22 April 2008.

32 Interviews. Marija Perkovć, Women in Black Activist, Belgrade (Vbras), 21 March 2008; Nadja Duhaček, Women in Black Activist, Belgrade, 22 April 2008.

33 Interview. Nada Dabić, Coordinator of Esperanca, Novi Sad, 13 May 2008.

st Ibid.

35 The official languages in Vojvodina are Serbian (Cyrillic), Croatian (Latin), Hungarian, Slovak, Romanian and Rusyn.

* Interviews. Lepa Mladjenović, Coordinator of Autonomous Women's Centre, Belgrade, 27 March 2008; Boban Stojanović, Coordinator, Quecria, Belgrade, 11 April 2008, and Biljana Stankovic, Coordinator, Novi Sad Lesbian Organisation, Novi Sad, 29 May 2008.
} 
security means; a way of thinking strongly connected to the feminist principle that the personal is political.

The senses of insecurity expressed by Nada are framed within the public discourse of Women in Black as a critique about militarised structures in Serbian society. Implicit within Nada's security concerns is a conviction about the structural impacts that war and nationalism has upon her sense of insecurity. These criticisms are reflected by other Women in Black activists: senses of insecurity included concerns relating to fears impeding upon everyday life; equality; freedom of speech and movement; economic, social and political stability, and human rights. The signification of security expressed by Women in Black activists rests upon discursive logics criticising militarism and its perceived consequences: war and nationalism. Within this critical conceptualisation of in/security, the referent subject is the gendered individual. Staśa Zajović did not expect activists to express a critical conceptualisation of security when she was organising the workshops, as she was 'sure that women would link security with repressive apparatus and the police', but activists emphasised a human security approach, based upon their experiences. ${ }^{57}$ Nada, and other Women in Black activists, have theorised about security from the starting point of contemporary insecurities faced by women in Serbia, relating this standpoint to the structural factors which activists believe have shaped insecurities they consider prevalent in Serbian society.

The conceptualisation(s) of security that Women in Black activists have influences how UNSCR 1325 is utilised, and concurrently, UNSCR 1325 has some bearing upon how "security" is thought about. The connections drawn between Women in Black's feminist-antimilitarist vision of security and their interpretation of UNSCR 1325 is clear from their publications, including a 96 page booklet published at the end of 2007 titled From the Traditional to the Feminist Concept of Security: Resolution 1325, disseminated in Serbian. After an introduction outlining various interpretations of "security" and providing information about the UN and UNSCR 1325, the booklet highlights the position of individual activists in relation to UNSCR 1325 and what activities Women in Black have carried out in this area. ${ }^{58}$ The security discourse underpinning this publication is highly critical, constructed in opposition to a traditional (state-centric) vision of security, with a strong ontological focus upon the gendered individual. However, for feminist-pacifists, including Women in Black, it is not enough for UNSCR 1325 to merely reinforce notions of Human Security, or to increase participation of women

\footnotetext{
37 Interview. Staśa Zajović, Coordinator, Women in Black, Serbia, Belgrade, 29 June 2008.

3. S. Zajović Od Tradicionalngg do Feministickog Koncepla Beqbednosti - Requluija 1325 (From the Traditional to the Feminist Concept of Sceurity: Resolution 1325) (Women in Black. Belgrade, 2007). My translation from Scrbian.
} 
in the armed forces. ${ }^{59}$ Rather, 'it is necessary to create a feminist and antimilitarist alternative' vision of UNSCR 1325. These alternative visions and interpretations of UNSCR 1325, which are explored later in this chapter, are shaped through 'a room of one's own'. With space for consideration and reflection, Women in Black activists could develop a vision of security connecting their personal experiences and understanding of Serbia's post-conflict problem to their political critiques of conflict and post-conflict.

\section{The Discursive Moment: Stating Security.}

As mentioned earlier, Women in Black activists began to explicitly articulate and represent their critical feminist-pacifist perception of gender security from 2005. These articulations and representations are best described as key discursive moments when it is possible to identify that Women in Black explicitly expressed "security" for political purposes: that is, security discourse invoked deliberately and with consideration by activists. The conception of a discursive moment more accurately conveys a sense that ideational values did not alter, shift, modify or change, but rather, that these values begun to be expressed differently and connected to different institutional terrains/concepts - such as UNSCR 1325 and a (critical) concept of security. The idea of a "turning point" is problematic for its progressive connotations, and so the notion of a discursive moment enhances how time and temporality is conceived of in this thesis: as fluid and yet momentarily (un)consciously fixed. One reason that Women in Black begun to explicitly articulate and represent "gender security" is the growing interest and attention being paid to the Women, Peace and Security agenda, and the introduction of UNSCR 1325 in 2000. This section will show how UNSCR 1325 gave impetus for the group's articulation of gender security, stressing the importance of the international context and agenda in relation to the women, peace and security frameworks.

During the Women, Peace and Democracy workshops held around Serbia during 2005, activists not only considered possible meanings of gender security, but also learnt about UNSCR 1325 . These workshops were financed through UN Trust Fund money, and as such, identification of a particular moment where a discourse appears to change throws up questions related to donor influence and agenda-setting within international politics. Denise Horn, in her study of US and Nordic gender policies in post-communist Estonia, highlights the importance of foreign funding in shaping civil society discourse, pointing to the perception amongst Estonian NGOs that certain 'magic words', including gender mainstreaming, democratisation, and gender equity need to be emphasised in foreign

59 Zajovic 'Peace and Security from a Feminist-Pacifist Perspective' p. 179. 
grant applications to be successful. ${ }^{60}$ NGOs in transition countries across the former Soviet Bloc and Latin America are considered to be susceptible to the priorities of foreign assistance. Studies of Russian grassroots organisations suggest that the goals and projects demanded of Russian NGOs by American donors are damaging for civil society, which becomes responsive to Western demands as opposed to local concerns. ${ }^{61}$

The concern that NGOs reliant upon foreign donor support mould their projects with the terminology which funders are considered to prioritise is echoed in literature concentrating upon former Yugoslavia - but the perceived agenda-setting is painted in more positive terms. Elissa Helms suggests that the desperate need of many NGOs in the region for international financial assistance mean that, in Bosnia-Herzegovina, the donor-orientated language of women's NGOs is infused with essentialist assumptions about female caring roles in society: multiethnicity, tolerance, reconciliation and refugee return.62 The political climate of postwar Bosnia means that deploying these essentialisms then becomes a valid strategy allowing 'women to gain moral authority and real, though indirect, power with which to achieve their often very political goals'. ${ }^{63}$ Aida Bagic examines how feminist activists across former Yugoslavia view impacts of international assistance: highlighting the perception that international donor organisations occasionally have preconceived assumptions about female experiences and needs in the region, affecting the agenda which donors wish to achieve. ${ }^{64}$ However, foreign assistance remains a valuable source of funding, training and expertise, opening opportunities for individuals and groups to develop. ${ }^{65}$

60 D. Hom 'Setting the Agenda: US and Nordic Gender Policics in the Estonian 'Transition to Democracy' Intemational Feminist Jowrmal of Politics, Vol. 10, No. 1 (2008), p. 70. Hom points to how Nordic donors prefer different "magic words" to American donors. \#

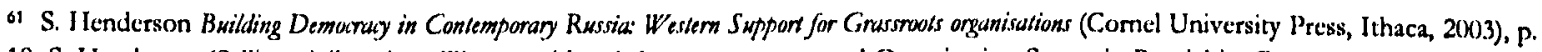
10, S. I Icnderson 'Selling civil society: Westem aid and the nongovcrnmental Organization Scctor in Russia' in Compurative Political S/wdies, Vol. 35, No. 2 (2002), p. 156, L. McIntosh Sundstrom Fixnding Civil Saciety: Foreign Asristance und NGO Detelopment in Rursia (Stanford University Press, Stanford, 2006), p. 170. Henderson is more vocal than Sundstrom in voicing these concerns. There is a wide range of academic literature dealing with the impact of westem funding in Eastern Europe, although the vast majority of the literature concentrates upon democracy promotion in Russia. See also J. Richter 'Evaluating Western assistance to Russian Women's Organisations' in S.E. 'Mendelson and J. K. Glenn (eds.) The Power and Limils of NGOs: A Critical Lank at Building Demacracy in Eartem Exmpe und Exnusia (Columbia University Press, New York, 2002), pp. 54 - 90. It should be remembered that there are differences (as well as similarities) berween Russia and Serbia; especially in relation to forms of communism (as discussed in chapter three) and Serbia's inside/outside conflict and postconflict situation (as discussed in the introduction). There is a very desperate gap in relation to literatures conceming foreign donor support towards NGOs that concentrates upon Serbia that this thesis only begins to address - albeit from a different angle - by recognising that international and transnational actors have impacted upon how women and feminist NGOs might use the discourse of "sccurity".

${ }^{62}$ E. Helms 'Women as Agents of Ethnic Reconciliation? Women's NGOs and International Intervention in Bosnia-l Ierzcgovina' Women's Studies International Forum, Vol. 26, No. 1 (2003) pp. 1824.

6.3 Ibid. p. 16.

64 A. Bagić Intermational Ascristance for Women's Onganiring in Sowth Eastem Lunope: From Groups and Initiutiues to NCSOs Ruport: CPS International Policy Fellowship Program 2001/2002 (Central European University Center for Policy Studies, Budapest, 2002), A. Bagić 'Women's Organising in Post-Yugoslav Countrics: Talking about "Donors" in J. Gould and H. S. Marcussen (eds.) Eithnographies of Aid, Occasional Paper Series, International Development Studies at Roskilde University.

${ }^{65} \mathrm{Ibid}$. 
The extent of donor influence is difficult to assess, but Women in Black 'work hard to not consent to political ransom or conditionality, but to build partnerships'.66 While there was an element of conscious instrumentalism on the part of Women in Black - to use UNSCR 1325 as part of their 2005 Women, Peace and Democracy project - activists have been careful to exploit the possibilities of UNSCR 1325 so that the resolution works to support their pre-existing feminist-antimilitarist discourse. Staśa Zajović, the coordinator of Women in Black in Serbia, insists that:

'Resolution 1325 is one of our subjects, one in many. It was simply a continuation of what we have been doing since we set up Women in Black. We have been dealing with security from the aspect of non-militarisation since 1991'67

Staśa makes the point concisely that the use of UNSCR 1325 is a perpetuation of the group's previous activities. Her emphasis upon "one" highlights how UNSCR 1325 is part of a far wider remit held by Women in Black. The resolution is viewed as an advocacy tool which can be deployed in order to achieve some of Women in Black's aims; particularly their non-militarised perception of security. This echoes the perception of an NGO activist in south-eastern Europe: to avoid inappropriate donor influence, activists have to first 'decide for yourself, who you are, what you are, what you want... You can move a little bit here and there, but you have to keep your line' ${ }^{68}$ International donor interests, while important in the instrumental use of specific gender security vocabulary, has not altered the long-held values and aims of Women in Black.

However, the international context has been important in simulating and creating an environment for a discursive emphasis upon "gender security". Since the introduction of UNSCR 1325, debates upon the meanings and ambition of "gender security" have intensified. Actions by Women in Black - Serbia that draw upon gender security frameworks are part of a (still growing) international interest in UNSCR 1325. Around the world, including in Palestine, Kosovo and Colombia, feminist-pacifists have incorporated UNSCR 1325 into their work - suggestive of the increasing influence that UNSCR 1325 and gender security frameworks have. 69 UNSCR 1325 has come to be seen as 'one of the many

\footnotetext{
(o) Zajović Alukyss Disobedient, pp. 78 - 80.

67 Interview. Stasia Zajović, Coordinator of Women in Black: Scrbia, Bclgrade, 29 June 2008.

6h Anonymous interviewee, cited in Bagić 'Women's Organising in Post-Yugoslav Countries: Talking about 'Donors' p16.

${ }^{69}$ S. Richter-Devroe "Herc, it's not about conflict resolutions - we can only resist": Palestine Women's Activism in Conflict Resolution and Non-violent Resistance' N. Al-Ali and N. Pratt (eds.) Women and War in the Middle East (Zed Books, London, 2009), pp. 158 - 190 discusses Palestinian feminist-pacifists; Cockburn From Where We Stund, pp. 152 - 155 touches upon Colombian feminist-pacifists. The feministpacifist movement in Kosovo was discussed in interview with Igballe Rugova, Coordinator Kosovo Women's Network, Pristina, 3 June 2008, although it should be highlighted that not all groups in the Kosovo Women's Network are feminist-pacifists.
} 
avenues being pursued in working towards the goals of the global women's movement'.70 Key actors in the global women's movement, including Felicity Hill, Director of the UN office of the Women's International League for Peace and Freedom have been strong advocates for the women, peace and security frameworks. ${ }^{71}$ Indeed, Staśa Zajović, the coordinator of Women in Black - Serbia, cites a 2001 meeting with Felicity Hill at a international conference as the initial moment that she became aware of the possibilities of UNSCR 1325.72 The presence of UNSCR 1325, reinforced by international advocacy efforts, simulated discursive emphasis upon frameworks utilising "gender security": encouraging Women in Black to formulate visions of gender security that is product/ive of their feminist-pacifist position.

The conceptualisation(s) of security developed by Women in Black activists influence how they utilise and respond to UNSCR 1325. Concurrently, the international context that surrounds UNSCR 1325 has a bearing upon how "security" is thought about. Knowing about, and having room to reflect upon meanings of "gender security" and the potential of UNSCR 1325 is a crucial aspect that makes using the resolution possible. Deploying UNSCR 1325 has not simply been a response to international donor concerns. Rather, the gender security frameworks that constitute UNSCR 1325 have been deployed to support and amplify the feminist-pacifist stances of Women in Black. The resolution opens up opportunities for grassroots actions when activists have space to reflect upon personal-political imaginations of conflict and post-conflict problems. These reflections allow Women in Black activists to put forward a vision of the resolution that fits in with their values as a feminist, antinationalist peace organisation, utilising UNSCR 1325 to reflect their hopes for the future direction of post-conflict reconstruction. The discursive terrain surrounding UNSCR 1325 including frameworks of gender and/or women, peace and security - has become increasingly emphasised internationally. With 'a room of one's own', Women in Black have negotiated a path through gender security frameworks that reinforces their ideational values, but enables activists to use UNSCR 1325 and its discursive terrain as an advocacy tool.

\footnotetext{
${ }^{70}$ N. Florea Hudson Gender, IIuman Secwrity and the United Nationsi. Security Language as a Palitical Frumework for Women (Routledge, Abingdon, 2010), p. 150.

71 The Women's International League for Peace and Freedom (WII.PI) is an international NGO that has consultative status with the UN to formally lobby the UN and its agencies on issues related to peace, disarmament and economic justice. Sce Hwy ukwilpfurgulb accessed 12 August 2010]. Felicity Hill is a long-term advocate for the women, peace and security project, and has worked for UNIIFEM and WILPF. For an in-depth examination of the role played by individuals in the women, peace and security project, see S. Basu 'Security Through Transformations: The Case of the Passage of UN Security Council Resolution 1325 on Women, Peace and Security' PhD Thesis, Aberystwyth University, 2009.
}

72 Interview. Staśa Zajović, Coordinator of Women in Black: Serbia, Belgrade, 18 September 2009. 


\section{USING “SECURITY” AND UNSCR 1325.}

Women in Black have utilised a critical conceptualisation of "gender security" and UNSCR 1325 in various ways. Between October 2005 and October 2008, there have been three actions developed by Women in Black that articulate and represent their conceptualisation of security, and which centre upon UNSCR 1325. First; the group's Draft Resolution on Women, Peace and Security, which includes specific localised suggestions for the implementation of UNSCR 1325 in Serbia. Second; UNSCR 1325 was used as a legal backbone for the demand that women should be included in the final status negotiations regarding Kosovo. Women in Black pursued this action in coalition with the Kosovo Women's Network prior to Kosovo's proclamation of independence on 17 February 2008. Finally; there has been an increasing reference to UNSCR 1325 in Women in Black's condemnation of the public attacks upon women's human rights defenders in Serbia. Women in Black have utilised UNSCR 1325 in other actions, but these three were selected because they were the most dominant actions that activists identified with UNSCR 1325 during interviews in 2008. ${ }^{73}$ The actions explored in the remainder of this chapter, underscore that UNSCR 1325 has become a tool to support the deployment of the group's critical conceptualisation of security. What becomes clear is the significant impact that gender politics has upon their use of UNSCR 1325: that is, Women in Black ensure that their feminist-antimilitarist stances shine through actions where gender security discourse is articulated and represented.

\section{(1) The Draft Resolution: Localising Women, Peace, and Security.}

For many feminist-pacifists, including Women in Black, UNSCR 1325 is problematic as the resolution itself does not challenge the existing structures and assumptions of the war system. ${ }^{74}$ UNSCR 1325 also faces criticisms for its 'conceptual gaps, for the lack of guidelines in practical application and for the failure in implementation', all sentiments echoed by Staśa Zajović, the coordinator of Women in Black. ${ }^{75}$ While it is very important that the resolution allows free space for creativity', Staśa feels that the looseness of the resolution is one of its potential problems. ${ }^{76}$ However, the looseness of UNSCR 1325 has allowed the resolution to be interpreted and applied to the specific issues faced by a particular state, and to be used as a tool to suit the political ambitions of actors. For example, UNSCR 1325 can be reinterpreted to support critiques of the war system or the processes

\footnotetext{
73 For an overview of Women in Black's work in rclation to gender security and UNSCR 1325, see Women in Black 'Women in Black Activities and Important Documents Related to the Implementation of Resolution 1325' (Report. March 2010). Available at htlp://wwriancucromumerg [accessed 26 july 2010].

${ }^{4}$ Cohn 'Mainstreaming Gender in UN Sccurity Policy' pp. 194-200, Cockbum From When We Stand, pp. 147-152.

73 Quotation retrieved from E. Porter, Peacebuilding: Women in an Intemational Perppectiue (Routledge, Abingdon, 2007), p. 3. S. Zajovic 'Peace and Security from a Feminist-Pacifist Perspective'. hutn://wwizicneucrnomorg [accessed 2 November 2007].

7 Interview. Staśa Zajović, Coordinator of Women in Black: Serbia, Belgrade, 29 June 2008.
} 
of militarisation that antiwar activists campaign upon. Women in Black have responded to UNSCR 1325 by applying the resolution to the post-conflict problems that activists identify as important. The following analysis of the Draft Resolution on Women, Peace and Security - produced by Women in Black in 2005 - highlights how UNSCR 1325 has been adapted to support the group's feminist antimilitarist stances.

Women in Black localised UNSCR 1325, to ensure that it 'was not just a global resolution', but a resolution with clear, tangible and plausible local possibilities. ${ }^{77}$ The Draft Resolution is an important articulation of Women in Black's position because it demonstrates ways in which UNSCR 1325 has relevance to their existing political objectives. The Draft Resolution has formed the focus of activities held by Women in Black on the anniversary date of the Security Council's passing of UNSCR 1325 on 31 October 2000. Each year - since 2005 - activists from Women in Black have presented to the National Assembly of Serbia a "Draft Resolution" with recommendations for how UNSCR 1325 could be implemented in Serbia. ${ }^{78}$ Recommendations within the Draft Resolution demand;

- The full and equal participation of women in decision making.

- Protection and respect for women's human rights and human rights defenders.

- Criminalization of the denial of war crimes and genocide.

- Adequate compensation and support to families of victims of war and war crimes.

- Effective implementation of the Family Law, and 'uprooting the culture of war which legitimizes violence against women'.79

These demands, indicative of the specific ways that Women in Black believe that UNSCR 1325 could be implemented in Serbia relate to the contemporary political, social and economic issues that activists are concerned about.

The Draft Resolution reinforces the critical, standpoint feminist perspective about gender that Women in Black have long campaigned upon. The document is based around the insistence that women's interest and participation in the peace-building process is crucial to 'establishing lasting and

\footnotetext{
$\pi$ Interview. Slavica Stojanović, Director of Reconstruction Women's Fund, Belgrade, 31 March 2008.

78 Women in Black 'Draft Resolution' in Women for Peace (Belgrade, 2007), pp. 187 - 189. Between 2005 - 2007, the presentation of the draft resolution was ignored by Parliament Deputies (although on a theoretical point, as UNSCR 1325 is a Sccurity Council document, all UN member states (including Serbia) have already accepted it: the debate is really about how to implement it in Serbia), but on October 31 2008, Women in Black and YUCOM were met by Parliament Deputies Snčzana Stojanović-Plavšić, Elvira Kovacs and Nikola Kovcaković.

${ }^{79}$ Women in Black 'Draft Resolution', pp. $187-189$.
} 
stable peace and security'. ${ }^{80}$ This statement highlights a conceptualisation that security is important for meaningful peace, and reinforces the attitude that women have a contribution to make within peace-building processes. The emphasis upon female agency echoes the group's rejection of images of women as passivematernalpeacelovers. The standpoint perspective that specifically demands the inclusion of female voices and participation is a response to the structural logics through which gender oppression and violence is understood. The Draft Resolution includes a recommendation that 'the culture of war which legitimizes violence against women' is challenged: reinforcing the group's long-held belief that dismantling the dominant militaristic values of society is a critical element of greater gender equality. Drawing upon an ontology that stresses the existence of patriarchal structures and practices for the silencing of female voices, Women in Black present a critical alternative: the participation of women in peace-building and post-war reconstruction processes.

The insistence upon female agency is viewed as an important opportunity offered by UNSCR 1325 , enabling Women in Black to highlight the key role Serbian feminists have played in the region in terms of their 'constant demands [for] responsibility for the war crimes'. ${ }^{81}$ Demands insisting that the state accepts responsibility for the war crimes committed during the 1990 s form a central kernel of the Draft Resolution. For example, the document includes demands for the application of lustration laws, stressing the importance of punishing those who committed war crimes, and includes a stipulation for the Law on Assistance to the Hague Indictees and their families to be revoked and the funds directed to humanitarian usage. ${ }^{82}$ There is a strong resonance with the demands first articulated in the early 1990 s for political responsibility, but these pre-existing discourses have been (re)articulated through contemporary realities. Reverberating through the Draft Resolution is an emphasis upon facing the past and the social and institutional changes that would signal a significant move towards accepting political responsibility. Throughout the Draft Resolution is an insistence upon practices of political responsibility which the NGO sees as a necessary achievement for successful post-conflict transformation.

The political position adapted by actors regarding Serbia's relationship to war and (post) conflict shapes how "security" - embedded within the discursive terrain of UNSCR 1325 - is conceived, and thus the ways in which UNSCR 1325 can be implemented in Serbia. Attitudes about pasts, presents,

\footnotetext{
Women in Black 'Draft Resolution', p. 187. See my own 'Expericnces, Reflections and Learning' for more analysis of the draft resolution.

11 Interview. Staśa Zajović, Coordinator of Women in Black: Serbia, Belgrade, 29 June 2008.

22 Women in Black 'Draft Resolution', pp. 187 - 189.
} 
and futures of conflict and post-conflict have a part to play in shaping how UNSCR 1325 is conceived. For instance, an integral value held by most Women in Black activists is the need for the Serbian state and society to face the past and accept responsibility for the war crimes committed during the 1990s: achieving this is fundamental to achieving security. Thus, for Women in Black, issues concerning political responsibility are a critical aspect for successful implementation of UNSCR 1325. It will become clear in chapter six and the conclusions how other political actors have different criteria for what constitutes a successful implementation of UNSCR 1325 - in part because of the ways that personal-political imaginations of conflict and post-conflict craft their gender politics and security discourse. "Gender security" within the Draft Resolution is discursively constructed through an emphasis upon political responsibility as a critical condition necessary to achieve peace and security: a position that reverberates through the group's pre-existing values, contemporary perceptions and future hopes.

\section{(2) The Women's Peace Coalition: Inclusion in Peace Processes.}

A second area where Women in Black activists utilised UNSCR 1325 and security discourse has been within the Women's Peace Coalition (WPC). The WPC is a coalition established in May 2006, bringing together activists from the Women in Black - Serbia network and the Kosovo's Women's Network. ${ }^{83}$ The founding principles of the coalition demand that 'the relcvant institutions adopt a concept of human security, especially security with a gender perspective, in keeping with UN Security Council Resolution 1325',84 Prior to Kosovo's proclamation of independence on 17 February 2008, the key objective of the WPC was the inclusion of alternative voices to the peace process. Since UNSCR 1325 reaffirms 'the important role of women in the prevention and resolution of conflicts and in peace-building', the WPC uses the resolution as a legal point of reference in its advocacy campaigns between $2006-8$ to argue for a women's place in the peace negotiations. ${ }^{85}$ While the Draft Resolution is an action based around promoting a particular interpretation of UNSCR 1325, the WPC, including activists from Women in Black, have used UNSCR 1325 as part of a range of legal documents to support their hopes for post-conflict reconstruction.

Coalitions are tricky to establish; and this is more so with the WPC where there are over one hundred groups between two networks - The Women in Black Network in Serbia and the Kosovo's Women's

\footnotetext{
83 The Kosovo Women's Network is a network of feminist and women's organisations from all parts of Kosovo. See letp:L/www.womensnerwork.org/ [accessed 20 August 2010]. The Kosovo Women's Network is less ideologically unified than the Women in Black Network, who are an explicitly feminist-pacifist network in Scrbia.

84 Women's Peace Coalition (lcaflct) 'Women's Peace Coalition' May 2006.

as Ibid.
} 
Network - each with diverse interests and histories. ${ }^{86}$ This diversity is especially obvious where UNSCR 1325 is concerned: both networks have a different history of using UNSCR. 1325, partly because Kosovo faced a different reality. Kosovo had a UN administration who should [have] implement[ed] the resolution, but this did not happen'.87 In response, women's organisations in Kosovo used UNSCR 1325 to hold to account the United Nations presence in Kosovo (UNMIK), to ensure that UNMIK considered gender issues. ${ }^{88}$ Women in Black, on the other hand, use(d) UNSCR 1325 to complement their lobbying activities and feminist-pacifist values. ${ }^{89}$ Despite different local circumstances and experiences, building a coalition and holding a unified public position was possible partly because of shared discursive logics concerning gender structures and achieving human security. The pre-existing values and aims of both networks collided with future hopes regarding post-conflict reconstruction to ensure a coherent policy that utilised UNSCR 1325 and security discourse to make their objectives heard.

The Women's Peace Coalition utilised UNSCR 1325 to support their shared objective for meaningful peace in the region. Feminists who had been active in Belgrade or Pristina during the 1990s spoke of long-term collaboration, stressing that they had always worked together to achieve peace. ${ }^{90}$ These existing networks were formalised in response to donor needs. ${ }^{91}$ The activities and meetings of the WPC were funded by UNIFEM (in 2006 and 2008) and UNDEF (in 2007) with technical support from UNIFEM in Pristina. ${ }^{22}$ UN agencies - like UNIFEM - can play a role in helping NGOs identify how their existing work fits into the UN agenda, supporting NGOS in decoding the maze of UN

M6 Interview. UNIJIEM representative (a), Pristina, Kosovo, 10 June 2008.

"7 Ibid.

st Interview. UNIIIIM representative (a), Pristina, Kosovo, 10 June 2008. See also the Kosovo Women's Network reports Monitoring Implementation of United Nations Security Council Resolution 1325 in Kosovo/a (Prishina, Kosovo/a, 2007; (2nd ed.) 2009).

${ }^{89}$ A detailed history of how the Kosovo Women's Network used UNSR 1325 can be found in I. Rugova (coordinator of the Kosovo Women's Network) 'Women, Peace and Security: Kosovo Women's Activists Efforts to Implement UNSCR 1325' in N. Farmsworth (ed.), 7 bmongh Women's Solidurity to a Just Peace: A Report based on the Wamen's Peace Caalition Second Annval Conference (Kosovo women's Network, Pristina, 2007), pp. 45 - 6.

* Interviews. Miloš Urošcvić, Women in Black Activist, Belgrade, 21 March 2008; Slavica Stojanović, Director, Reconstruction Women's Fun, Belgrade, 31 March 2008; Milhane Nartilé Salihu-Bala, Women in Black Activist, Pristina, Kosovo, 3 June 2008; Arjeta Rexhaj, Exccutive Director; Gender Studies and Training Centre, Pristina, Kosovo, 6 June 2008. Interestingly, even those who were not active during the 1990s, or had never visited Belgrade or Pristina, stressed this long-term collaboration, suggesting that the collaboration between feminists in Belgrade and Pristina collaborated during the 1990s is an important group memory and history (re)produced in relation to the WPC. During many protests in the late 1990s, Women in Black used a banner declaring that 'Albanian Women are our Sisters' to publically show solidarity. See 'Our Silence is Visible' Women for Peace (Women in Black, Belgrade, 1996), p. 6. It should be remembered that since it was dangerous for "Serbian" women to publicly show solidarity with "Albanian" women, these displays were indicative of a strong bond a point that activists in both Belgrade and Pristina commented upon.

$\eta 1$ Interview. Feminist Peace Activist, Pristina, Kosovo [off the record upon request].

92 Interview. UNIFEM representatives (a) and (b), Pristina, Kosovo, 10 June 2008. UNDEF requires support from another UN agency before NGOs can access its funds: this support was provided by UNIFEM. This particular funding bid, submitted at the end of 2006, was successful and was allocated \$296,800: project reference UDF-KSV-06-069. Information retrieved

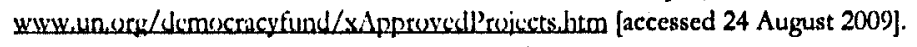


structures. The concern for a means of funding their activities may have impacted upon the way the WPC articulated its objectives, but these funding concerns did not alter objectives. A UNIFEM representative in Pristina emphasised that the WPC, is not about the resolution, it's [about] peace. Women and peace is more than a resolution, so the resolution is a tool. ${ }^{{ }^{x 3}}$ That is, UNSCR 1325 is a vehicle supporting ambitions of women's organisations in securing lasting peace. These sentiments were echoed by the leaders of each network, Staśa Zajović and Igballe Rugova, highlighting that UNSCR 1325 was used as a tool to support their peace-building and peace-keeping activities. ${ }^{94}$

UNSCR 1325 was used to support a particular configuration of gender security that activists of the WPC wished to promote: the inclusion of women in the negotiations for the final status of Kosovo. Since the end of the 1998-99 Kosovo War, and the NATO bombing of Serbia and Kosovo in 1999, Kosovo has been administrated by UNMIK, under the terms of UNSCR 1244. Prior to Kosovo's declaration of independence from Serbia on 17 February 2008, discussions were underway to negotiate the terms of an agreement that would settle the final status of Kosovo. However, it was felt that these negotiations did not include a broad range of gender perspectives, as explained by Igballe Rugova, the coordinator of the Kosovo Women's Network:

When the negotiations started for the final status of Kosovo, there were no women in the negotiation team. There was one women from Serbia, but she was a terrible radical fascist. So we decided to form a coalition to bring a women's perspective to the negotiation'.95

Igballe acknowledges that there was a women present in the peace negotiations, but she was thought to be a 'terrible radical fascist'. Rather, what is thought to be missing is the feminist pacifist perspective from the final status negotiations." UNSCR 1325 is invoked to support the WPC's claim for a feminist-pacifist voice in the final status negotiations. ${ }^{27}$ For instance, in February 2007, the WPC wrote a letter to the UN Secretary General Envoy, President Martti Ahtisaari, to insist upon inclusion in the peace negotiations, explicitly referring to UNSCR 1325 as a legal document by which the UN are required to ensure the inclusion of a gender perspective. ${ }^{98}$ UNSCR 1325 was used to provide

\footnotetext{
${ }^{3}$ Interview. UNIFEM representative (a), Pristina, Kosovo, 10 June 2008.

94 Interviews. Staśa Zajović, Coordinator of Women in Black: Serbia, Belgrade, 29 June 20108; Igballe Rugova, Coordinator, Kosovo Women's Network, Pristina, Kosovo, 3 June 2008.

25 Interview. Igballe Rugova, Coordinator, Kosovo Women's Network, Pristina, Kosovo, 3 June 2008.

96 Women's Peace Coalition (Press Release) Women's Peace Activists from Kosova and Scrbia agrce on independence for Kosova' (Pristina/Belgrade, 5 September 2006). Retrieved from htupi//www nedicumondialcioro [accessed 8 December 2007].
}

${ }^{27}$ N. Farmsworth (cd.), Through Women's Solidarity to a Jwst Peate: A Repont based on the W'omen's Peace Coalition Second Annual Conference (Kosovo
Women's Network, Pristina, 2007) Women's Peace Coalition conference rcport, pp. 48, 50, 54.

98 Women's Peace Coalition, letter to President Martti Ahtisaari, UN Secretary Gencral Envoy in Charge of the Negotiations on the Future Status of Kosovo (8 February 2007), retrieved from bttpi//wwwiacncucenomury on 29 November 2007 
international legitimacy in support of the WPC's campaign for the inclusion of a feminist-pacifist voice in the final status negotiations.

Inclusion in the peace negotiations is an important aspect of gender security. 99 The WPC's insistence upon the necessity of a feminist-pacifist voice in the final status negotiations resonate with the discursive logics about gender that underpins Women in Black's critiques of militarism. The feminist standpoint ontology emphasising knowledge based upon personal experience stresses the importance of including a feminist-pacifist voice. A feminist-pacifist voice ensures that 'the needs of all citizens women and men - form the basis for peace and security' in the final status negotiations. ${ }^{100}$ This gender-inclusion perspective is based upon an organisational logic which presumes that including female voices alongside the male voices already present means better and more effective conflict resolution. A standpoint feminist perspective argues that women are effective peace-makers because they focus upon reaching a nuanced understanding of the root causes of conflict, address inequalities, injustices and oppression causing and caused by conflict. ${ }^{101}$ Ultimately, the WPC used UNSCR 1325 prior to Kosovo's declaration of independence as an advocacy tool to support their claim for a feminist peace perspective to be included in the final status negotiations.

\section{(3) Women's Human Rights Defenders: Voicing an Alternative.}

The final activity discussed in this chapter where Women in Black have utilised UNSCR 1325 relates to the protection of activists vocalising support for the political responsibility project. Women in Black frequently experience media abuse, social violence and institutional attacks. These threats are not exclusively aimed at Women in Black activists, but activists from the group been attacked. ${ }^{102} \mathrm{~A}$ public memorial service for the victims of Srebrenica held on 11 July 2009, saw abuse directed at Women in Black activists by members of nationalist groups Obraz and 1389.103 In February 2007, Stasa Zajovic, the coordinator of Women in Black, was accused of being a criminal by the newspaper

\footnotetext{
29 Porter Peacebuilding, p. 37.

10 Women's Pcace Coalition 'Women's Peace Activists from Kosova and Serbia agree on independence for Kosova'.

tol S. N. Anderlini 'Peace Negotiations and Agrcements' in Hunt Alternatives Fund and Intemational Alert Inclusive Security, Sustainable Peax: A Toolkil for Advocacy and Action (London, 2004), p. 25, and Porter, Peacebuilding, p. 34.
}

${ }^{102}$ A good summary can be found in Women in Black Women for Peace (Women in Black, Belgrade, 2007), pp. 208 - 220. Activists reported these abuses to be noticeably worse under the conservative leadership of Vojislav Koštunica (President 2000 - 2003, Prime Minister 2004 2008).

103 B92 'Predlog Deklaracije o Srcbrenici' (Proposal for Declaration on Srebrenica) 11 July 2009 htrp://wrwib22.nct/intiu [accessed 1 August 2009]. My translation from Serbian into English. Obraz and 1389 are both neo-Nazi groups who believe in the ideology of a "Greater Serbia", usually including thetoric stating that Kosovo is Serbian, that the Hague Tribunal is unjustly persecuting Serbs and that Serbia and Serbs suffered the most at the hands of Bosniks, Croats and Albanians. 
Kurir after the WPC issued a joint statement advocating an independent Kosovo. ${ }^{104}$ In January 2007, two Women in Black activists were physically attacked by three men who had said 'see that faggot... you are part of Women in Black'.105 During summer 2005, Women in Black were subjected to an intrusive police investigation for the bizarre charge of organizing prostitution. ${ }^{106}$ Media insults and attacks are frequently wrapped up in gendered language. For example, Bilijana Kovačević-Vučo, a highly distinguished human rights lawyer, has been described as a 'legal whore', a 'vampire', an 'owner of an unused brain... an old women who lost her period when Tito died'.107 The abused faced by activists draws upon gendered constructions: women who act as human rights defenders are not fulfilling the social expectations of a Serbian women either domestically (as good wives) or in the public sphere (as attractive and passive women). ${ }^{108}$ These attacks take place because the political responsibility project pursued by Women in Black is socially and politically unpopular.

In response to these attacks, UNSCR 1325 is referred to as part of a body of documents intended to protect women's human rights defenders. For example, a conference titled Women, Peace and Security, jointly organised by Women in Black and Lawyers' Committee for Human Rights, was held on 30 October 2008, deliberately timed to coincide with the eighth anniversary of UNSCR 1325. The conference aimed to 'raise awareness about the issue of security of women and women human rights defenders, as well as to discuss instruments for their protection - Resolution 1325 and the so-called UN Declaration on Human Rights Defenders'. ${ }^{109}$ During the conference, discussions about human security and UNSCR 1325 were related to the insecurity of human rights defenders in Serbia: security would mean feeling safe to voice an opinion about the importance of the political responsibility project. ${ }^{10}$ For Women in Black, since UNSCR 1325 is about putting forward an alternative vision of

\footnotetext{
104 Women in Black 'Announcing a New Wave of Repression Against Women in Black' (Press release. February 2007). http://Wwwiencucinom.org [accessed 11 December 2007].

${ }^{105}$ Miloš Urošević and Violeta Dikanović were attacked. Women in Black Women for Peace (2007), p. 216.

100 Women in Black Women for Peace (2007), pp. $213-215$.

${ }^{107}$ The quotations are from the daily popular press newspapers Danas reporting on March 102004 , and Kurir reporting on July 12004 , extracted from Lawyers Committee for I luman Rights:YUCOM The Case of Citil Sentunt Alcksander Tijanic (Grafonin, Belgrade, 2005), p. 192. This book is a collection of press cutting gathered from the Serbian press in the build-up and aftermath of Prime Minister Zoran Djindic's assassination in March 2004. Aleksander Tijanic was President Kostunica's advisor, and is the director of RTS (Radio Television Serbia). Vampires have a special place within Serbian mythology - the English word Vampire is derived from the Scrbian Vampir - and in Slavic lore, a vampire is thought to be the manifestation of a spirit possessing a decomposing body, and an undead creature jealous and vengcful towards the living.
}

${ }^{108}$ Interview. Biljana Kovaćević-Vućo (Director) and Milian Antonijević (Tixccutive Director), Committee of Lawyers for Human Rights, Belgrade, 8 June 2009.

1 (ro YUCOM Campaign to Promole UN Decluration on Iluman Rights Defenders in Serbia (Bclgrade, 200\%), p. 6.

110 Women in Black (Conference Report) 'Žene, mir, bezbednost. Rezolucija 1325, 30 i 31 oktobar 2008' (Women, Peace, Security: Resolution 1325, $30-31$ October 2008] in Zene za mir [Women for Peace] (Women in Black, Belgrade, 2009), pp. 215 - 220. My translation
from Serbian into English. 
security, where the 'basic subject of security are citizens, not states', then if the Serbian state is to be successful in implementing UNSCR 1325, it is necessary to penalise those who place human rights defenders in an insecure position. ${ }^{111}$ The alternative vision of gender security put forward by Women in Black means that UNSCR 1325 becomes one strategy deployed to support claims to protection as a human rights defender.

Achieving gender security would mean changing the social values that condone abuses towards women's human rights defenders. In February 2010, the Serbian Ministry of Defence publicised a draft National Action Plan (NAP) for the implementation of UNSCR 1325 in Serbia. Women in Black criticised the draft NAP for failing to recognise fully that 'women are actors of peace and not only victims of war', pointing out that,

'animosity towards female activists of civil society is still present, especially towards those who request responsibility for the war and war crimes... the role of the implementer [of the NAP] is enormous - in the sense that it requires the penalisation of all those who jeopardise the security of human rights defenders.'112

For Women in Black, gender security means more than protecting the victims of war. Gender security is secured if activists feel safe to voice their views about the necessity of the political responsibility project in Serbia. In the eyes of Women in Black activists, full implementation of UNSCR 1325 in Serbia requires a shift in attitudes from state institutions, including the Ministry of Defence. Women in Black believe that by punishing those who jeopardise the security of human rights defenders', the militaristic values supporting evasion of political responsibility will be challenged. UNSCR 1325 is used as a tool to support a critical conceptualisation of gender security that ties in with the group's long-held belief about the importance of challenging and altering social values.

The emphasis upon the insecurity of human rights defenders arises out of the experiences of Women in Black activists. Women in Black activists face abuse and violence for voicing their views about the necessity of the political responsibility project: it is this experience that has given activists particular insights and perceptions about what gender security could mean. Cynthia Cockburn stresses that for feminist antiwar activists, 'a particular perception of war comes from a combination of a certain location and a certain positionality'.113 The feminist-pacifist position adapted by activists has been

'1' Women in Black 'Women in Black Activities and Important Documents Related to the Implementation of the Resolution 1325' Report, March 2010. hetpi//wwwezcnucromom.ury [accessed 26 July 2010].

112 Ibid. p. 5.

${ }^{113} \mathrm{C}$. Cockbum 'Gender Relations as Causal in Militarization and War: A Feminist Standpoint' Intemational Feminist Jowrnal of Politics, Vol. 12 , No. 2, p. 146. 
shaped by their problematisation of war and post-conflict. That is, the critique of militarism developed by Women in Black includes the perspective that the political responsibility project is necessary for long-term and sustainable conflict resolution. However, this very problematisation of post-conflict places activists at risk of being attacked, increasing their perception of insecurity. This sense of insecurity matters to Women in Black activists, as they believe these abuses to be connected to the practices and processes of militarism. By drawing upon a feminist standpoint perspective emphasising the importance of experiences, activists have highlighted areas of personal insecurity, emphasising that these experiences are political.

\section{CONCLUSIONS.}

The responses of Women in Black to UNSCR 1325 demonstrate how the group's particular configuration of gender security within UNSCR 1325 echoes their long held feminist-pacifist position. In other words, Women in Black's personal-political imaginations of conflict and post-conflict crafted a specific logic of gender security. The gender logics of Women in Black's response to UNSCR 1325 rests upon an standpoint feminist analysis of war, where war is understood as a consequence of deeper problems in society. The articulation and representation of gender security discourse has become another patchwork square within Women in Black's feminist-pacifist discourse. The investigation of the group's feminist-pacifist position, undertaken in the first part of this chapter, highlighted a gender politics based around a critique of militarism and an insistence upon political responsibility. The alternative vision of gender security articulated and represented by Women in Black echoed the discursive logics of their feminist-pacifist stances. The second part of this chapter discussed how activists learnt about and reflected upon UNSCR 1325 and the concept of gender security. Through a 'room of one's own' to reflect upon UNSCR 1325 and meanings of gender security, activists developed an understanding that reinforced their long-held feminist-pacifist positions. The final part of this chapter examined how the growing international emphasis upon gender security discourse opened up opportunities for UNSCR 1325 to be utilised to support Women in Black's advocacy work. In the production of a Draft Resolution, cooperation with the Kosovo Women's Network, and insisting upon the importance of security for women's human rights defenders, Women in Black have deployed UNSCR 1325 to support a configuration of gender security that reinforces their feminist-pacifist politics.

The problematisation of war and conflict offered by Women in Black activists affects how security discourse is thought about, and attitudes towards UNSCR 1325. Some groups in Serbia have been deterred from using UNSCR 1325 to support their activities because the document is perceived to be 
embedded within the language of conflict and post-conflict. Certain 'organisations or individuals would say that, maybe [it is not important] to push so much for [UNSCR 1325], and members say that, "I'm so, so tired of this conflict, I don't want to do that, I want to go forward"..114 Given that UNSCR 1325 refers to women in conflict and post-conflict zones, groups who, as discussed in chapter three, distance themselves from the terminology of conflict and post-conflict, will also distance themselves from UNSCR 1325. Women in Black, on the other hand, maintain a personalpolitical perspective where problems and issues arising from conflict and post-conflict reconstruction need to be addressed, and so interpret the resolution as an integral part of their work. UNSCR 1325 is problematic for some feminist-pacifists, since the structures of the war system are not addressed.115 However, Women in Black have (re)interpreted UNSCR 1325 to support an alternative, radical vision of gender security that addresses what activists identify as central post-conflict problems in Serbia: enduring militarism in Serbian society and politics, and the evasion of political responsibility for the war crimes committed during the 1990 s.

Personal-political imaginations of conflict and post-conflict have proved critical to bow UNSCR 1325 has been interpreted by Women in Black. The personal experiences and perceptions of conflict and post-conflict that activists reflected upon in a 'room of one's own' is product and productive of a political discourse that critiques militarism and insists upon political responsibility. The discursive emphasis upon frameworks of gender security within the international context has opened up spaces for political instrumentalism of UNSCR 1325 and discourses of gender security to reinforce the group's feminist-pacifist values. UNSCR 1325 has been utilised by Women in Black in an innovative way that builds upon, and challenges, the primary intention of the resolution to intervene into the organisation of the UN system in post-conflict contexts. Laura Shepherd has argued that UNSCR 1325 (re)produces a particular configuration of (international) security and (gender) violence that reasserts the primacy of an international "community" in resolving gender concerns."16 While UNSCR 1325 is constituted and constrained by the discursive terrain in which it is embedded, it is possible to "read" and utilise the resolution in alternative ways. By using their critical conceptualisation of "security", Women in Black have employed the resolution to legitimise and raise the profile of their critical, human-centred and gendered conceptualisations of security.

\footnotetext{
114 Interview; Anna Lidstrom, Kvinna Till Kvinna: Serbia (Belgrade, 30 May 2008). Speaking from her personal perspective, taking an overview of the women's and feminist movement in Serbia.

11 Cohn 'Mainstreaming Security in UN Security Policy' p, pp. $196-7$.

116 Shepherd Gender, Violence and Security.
} 


\section{CHAPTER SIX.}

\section{PULLING THE TRIGGER: GENDER, DOMESTIC VIOLENCE AND SECURITY.}

Gender security is a discourse provoking practices moulding the advocacy work of feminist and women's NGOs. However, this does not necessarily mean that "gender security" is explicitly pondered upon: as Lene Hansen points out, 'the concept of 'discourse' is not equivalent to 'ideas'; discourse incorporates material as well as ideational factors'. That is, gender security discourse is not just an idea: it is also a set of practices shaping political action. In the context of this thesis, emphasising the material element of discourse generates questions about how gender security discourse has affected the advocacy work of feminist and women's organisations in Serbia - even where activists are not explicitly reflecting upon frameworks of "gender security" or UNSCR 1325. This chapter investigates how increasing international concerns about post-conflict gender and security has been productive of concerns that link domestic violence with Small Arms and Light Weapons (SALW) abuse. SALW abuse in domestic violence has climbed up the profile of gender violence concerns in Serbia following increasing performances of gender security concerns in postconflict contexts. By focussing upon the domestic violence debate in Serbia, this chapter illustrates how gender security discourse has affected the practices of feminist and women's activists, altering the profile of the domestic violence agenda in Serbia.

Domestic violence debates in Serbia rarely draw upon conceptualisations of security concerned with bezbednost (see chapter four). However, in this chapter I argue that international notions of Human Security - a reconceptualised vision of bezbednost - has encouraged the (re)articulation of concerns about SALW abuse. While the previous chapter focused upon the ideational element of discourse, this chapter emphasises the effect that the international context has upon the performativity of discourse. As discussed in chapter three, I follow Judith Butler's notion of performativity, where an act is not 'singular or deliberate', but rather a 'reiterative and citiational practice by which discourse produces the effects that it names'.2 This avoids norm-emergence explanations which leave unanswered questions about why particular issues are further up the agenda than others, and means asking questions about how gender security discourse is (re)produced in particular ways in certain

1. I Iansen Security As Prattice: Discourse Anabysis und the Bosnian War (Routledge, Jondon, 2006), p. 17.

2 J. Butler Bodies thut Matter: On the Disizrsie Limits of "Sex"(Routledge, London, 1993), p. 2. 
contexts. The existence of UNSCR 1325 and (international) gender security discourse has triggered a chain of actions and responses that has subsequently altered the profile of the domestic violence agenda in Serbia, demonstrating how a discourse is a reiterative and citational practice reshaping the pattern of advocacy campaigns.

Domestic violence is an issue attracting a disparate range of actors in Serbia: including activists from women and feminist organisations, organisations with a gender concern, state and international institutions, and the media. This diversity means different networks, connections, visions and agendas exist, and that there is limited ideological coherence, even amongst NGO activists. As a generalisation, within NGO activists sharing an interest in addressing domestic violence in Serbia, there are two positions which are portrayed in opposition to each other. As discussed in chapter three, there are "political" feminists who urge for political responsibility and connect domestic violence to war and nationalism. ${ }^{3}$ At the other extreme, some activists believe that there is no important connection between gender violence and post-conflict realities: they point out that domestic violence is a global concern. ${ }^{4}$ Neither position is absolute. Additionally, there is a huge range of gender violence concerns in Serbia, including sex-trafficking and war-related rape. To understand how the practices of NGOs have been altered by the performance of a specific gender security logic, it is necessary to focus on one issue. By focussing upon advocacy efforts to tighten legal loopholes concerning the circulation of SALW, we can better assess the effects of gender security discourse upon the domestic violence debate.

The analysis in this chapter reflects upon policy and politics surrounding domestic violence in a different way. Much of the existing academic literature generated about domestic violence has been inspired by feminist comparative policy theory, which concentrates upon institutional factors. ${ }^{5}$ These studies provide enormous insights into ways in which national policy-making has been influenced by feminists, pointing to the structural factors benefiting feminists attempting to alter government policy concerning domestic violence. This chapter takes a different approach, and focuses upon the performance of security discourse within the debate and actions of actors concerned with domestic

\footnotetext{
"In relation to domestic violence, these "political feminists" include NGOs that are part of the informal "feminist coalition" discussed in chapter three. Outside of Belgrade, groups include Sandglass (Kruševac); SOS Women and Children (Vlasotince); Women's Altemative Workshop, (Kikinda) and Women for Peace, (Leskovac).

4 This perspective was voiced by (some) activists at Women's Centre Obrenovac and Women's Alternative, Sombor during group intervicws on 16 April 2008 [Obrenovac] and 20 May 2008 [Sombor].

SFor example, sec chapter nine in A. G. Mazur Theorizing Feminist Poligy (Oxford University Press, Oxford, 2002), S. L. Weldon Protest, Polig, and the Problem of Violence against Women: A Cross-National Comparison (University of Pittsburgh Press, Pittsburgh, 2002), J. Bond and R. Phillips 'Violence Against Women as a Human Rights Violation: Intemational Institutional Responses' in Soumebook on Viokence Against Women (eds.) Claire M. Renzetti, J. L. Edleson and R. K. Bergen (Sage Publications, Thousand Oaks, London, 2001), pp. 481 - 499.
} 
violence. This approach exposes the effects of particular discourses upon activist perceptions and judgements made of political opportunities. Highlighting the role of international gender and security discourse illuminates how the profile of domestic violence debates in Serbia has changed in response to these international discourses. This chapter is guided by an interest with how gender security discourse is performed within domestic violence policy in Serbia, highlighting how personal-political imaginations of conflict and post-conflict amongst activists have affected the articulation and representation of gender security.

The first part of this chapter outlines the discursive logics underpinning the narratives given by feminist and women's organisations in framing the problematisation of domestic violence in Serbia. The concern with SALW abuse within domestic violence will be discussed, highlighting partnerships between activists from the Victimology Society of Serbia and international institutions. While the Victimology Society of Serbia is not an explicitly feminist NGO, the group has feminist roots and connections, and is known in Serbia for its gendered research and work on domestic violence. ${ }^{6}$ Since 2008, financial and technical support to allow the Victimology Society to work on SALI in domestic violence concerns has come from South-Eastern European Small Arms Clearinghouse (SEESAC) and the International Action Network on Small Arms (IANSA): both international organisations with a particular concern for SALW. The second part of this chapter will focus on the convergence between international human security and gender mainstreaming concerns, suggesting that these international discourses have stimulated actions in Serbia that connect SALW and domestic violence. The final section of this chapter evaluates ways that gender security discourses have affected the profile of the domestic violence debate in Serbia, highlighting civil society activities between April 2008 and June 2009 concerned with SALW abuse. The analysis will expose ways in which gender security discourse - specifically UNSCR 1325 - has intervened into feminist concerns about domestic violence.

\section{GENDER POLITICS AND THE DOMESTIC VIOLENCE DEBATE(S)}

Domestic violence has long been a concern of feminist and women's organisations, and - as explored in chapter three - the first autonomous feminist civil society organisations in Serbia focussed on domestic violence. This section considers how perceptions of war, conflict and post-conflict shape the framing of domestic violence concerns in Serbia. Focussing on approximately 30 interviews conducted during 2008 and 2009 with activists working on domestic violence issues, and a range of relevant activist-academic publications, this section illuminates some of the discursive logics

- Interviews wich Vesna Nikolic-Ristanović, Director, Victimology Socicty of Serbia, Bclgrade, 10 July 2008, and Jasmina Nikolić, Victimology Society of Serbia, Belgrade, 18 September 2009 discuss the feminist orientations of the Victimology Society. The NGO's website is www.1disorg.ju [last accessed 13 December 2009]. 
presented by civil society actors underpinning problematisations of domestic violence. The discursive logics framing some civil society explanations about domestic violence in Serbia are supported by structural critiques about the effects of war and post-war institution-building. Towards the end of this section, the way that SALW concerns are located within these contexts of conflict and postconflict will be investigated. Understanding these problematisations not only provides a contextual overview of the domestic violence problems in Serbia, but also highlights the discursive constitution of issues deemed to be important, demonstrating how advocacy campaigns against domestic violence are framed. To notice the ways that gender security discourse has triggered changes to the contours of the domestic violence debate, attention first needs to be paid to the discursive logics framing domestic violence concerns in Serbia.

A perception which understands the framing of domestic violence concerns in Serbia as a narrative draws attention to the ways in which language has a productive nature: it is through discourse that problems and subjectivities are constructed. This argument is made by Laura Shepherd, who points out that 'while the acts of violence are 'true' and their telling is important, it is vital to be aware of the politics of constructing these accounts'.7 Put differently, the political profiles and concerns of activists within feminist and women's organisations affect the specific and particular domestic violence concerns highlighted. This enables a better focus on the impact of UNSCR 1325 and international gender security discourse upon the configuration of the broader domestic violence agenda. The gender politics of activists shape views about the impact of transitions upon Serbian society and the way in which institutions (do not) respond to gender violence concerns. Perceptions about postconflict problems and institutional efficiency also have bearing upon raising the profile of SALW abuse in domestic violence, but, as will become clear later in this chapter, SALW abuse concerns are pushed higher up the advocacy agenda as a result of international gender security discourse.

\section{Discursive Logics: (1) Transitions.}

Activists highlighted ways domestic violence concerns changed with each political transition in Serbia: the collapse of communism, war and economic crisis, and the transition to democracy. These narratives 'focus on the process by which we have constructed origins and given meaning to particular representations of the past, representations that continuously guide our daily lives and set clear limits to political and social options'. ${ }^{8}$ The particular representation of the past forming a discursive logic at the heart of the narrative about domestic violence reproduced by some feminist

\footnotetext{
'L. J. Shepherd 'Loud Voices Behind the Wall: Gonder Violence and the Violent Reproduction of the International' Millenniwm Journal of Inermalional Studies, Vol. 34, No. 2 (2006), p. 401.

- R. Bleiker Popular Dissent, Human Agengy and Globul Politics (Cambridge University Press, Cambridge, 2000), p. 25.
} 
activists stressed the effects of war upon the type of domestic violence experienced. These structural concerns place emphasis upon a particular discursive framing of socio-economic factors and how the contours of the debate are shaped. That is, the dominant activist narrative in relation to domestic violence in Serbia reads that: $\mathbf{x}$ event (like nationalist war) produced $\mathrm{y}$ outcome (increase in domestic violence linked to nationalism). The most common narrative used to explain the incidence of domestic violence in Serbia refers to the wars in former Yugoslavia during the 1990s.

For many, the outbreak of war and the subsequent disintegration of Yugoslavia marked a discontinuity from the socialist era, with a connection drawn between the alteration of political structures and understanding of domestic violence. Long-term activist Zorica Mrsevic felt that,

'the war opened our eyes, to put it shortly. Before the wars, of course it [domestic violence] was an issue, and feminists knew before the war that it was not a private issue, [but it was somehow] easier for us because in Communist times there were certain informal or party mechanisms to deal with domestic violence'?

Reverberating through Zorica's perspective is a sense of temporal discontinuity emphasising the structural change that war had: i.e. the mechanisms for dealing with domestic violence. During the state socialist era informal mechanisms where the party dealt with reported perpetrators of domestic violence were common. ${ }^{10}$ With the collapse of Communism, across Central and Eastern Europe, there was a drive by women's organisations to highlight the prevalence of violence against women, as the institutions which had restrained domestic violence disappeared." Differentiating a postcommunist era from a Communist era allows feminist activists to point to the impacts of structural changes in the system. The structural logics underpinning some activist understandings and interpretations of the reasons for domestic violence provided some with an impetus to speak'out. In Serbia, activists connected the collapse of communism with the outbreak of war, highlighting these factors as a reason for the inability of state institutions to deal with violence against women.

Against the background of war, organisations dealing with domestic violence emerged. For many activists, violence against women was a consequence of the patriarchal structures of war and conflict. Groups established during the early 1990 s focussing on domestic violence, including the

\footnotetext{
'Interview. Zorica Mrscuic, Deputy Ombudsman for the Republic of Scrbia, Belgrade, 9 June 2009.

10 Intervicw, Zorica Mrsević, Deputy Ombudsman for the Republic of Serbia, Belgrade, 9 June 2009. See also I. Marcus 'Dark Numbers: Research on Domestic Violence in Central and Eastem Europe' in V. Nikolić-Ristanović (ed.) W'omen's Rights and Sacial Trunsition in the l'RJ (Center for Women's Studies, Research and Communication, Belgrade, 1997), p. 116.

"D. Roman 'Gendering Eastem Europe: Pre-Ieminism, Prcjudice, and East-West Dialogucs in Post-Communist Romania' Women's Sindies Intermational Fiorum, Vol, 24, No. 1, (2001) pp. 57 - 59, V. Nikolic-Ristanović Sociul Cbange, Gender and V'iolence: Post-Communist and urur affected sacieties (Kluwar Academic Press, Dorstecht, 2002), p. 150, and Violence Against Women in Post-Communist Socictics: Benefits and Changes' Occasional Paper, East European Studies at the Woodrow Wilson Intemational Center for Scholars (May 2001), p. 20.
} 
Autonomous Women's Centre (AŽC), tended to link domestic violence with wider social and political violence. The initial aims of the AŽC when it was established in 1993 was to 'organise support to women raped in war', and women 'who experienced male assault, wartime violence and refugeeism [sic]'.12 AŽC was set up as a response to the consequences of war, guided by the belief that 'violence against women is a consequence of socially constructed unequal distribution of gender power'. ${ }^{13}$ In other words, violence against women is a consequence of structural factors, and in particular the patriarchal structures of conflict. Thus, a discursive connection is made between warbased violence and insecurities of the early 1990s, and domestic violence. These transitions become a way of explaining particular changes identified in the nature of domestic violence: that is, activists identified patriarchal structures made worse by violent and nationalist conflict as a reason for the increase in domestic violence.

Feminist activists explained the apparent increase in domestic violence during the 1990 s by emphasising how war altered images and expectations surrounding "masculinity" and "femininity".14 As a consequence of war and widespread social violence, hegemonic, marginalised, and/or toxic images of masculinities were perpetuated. It was felt that a 'criminal-warrior type of masculinity' ubiquitous in Serbia during the early 1990 s - affected gender violence. ${ }^{15}$ For example;

- Volunteers at SOS Hotline and AŽC noticed the presence of 'post-TV news violence', describing an increase in domestic violence following the screening of brutal images on the Serbian news. ${ }^{16}$

- Activists argued that post-traumatic stress syndrome amongst soldiers returning from the front resulted in particularly aggressive domestic violence. ${ }^{17}$

12 Directory of Women's Groups in Serbia 'Autonomous Women's Center Against Sexual Violence'

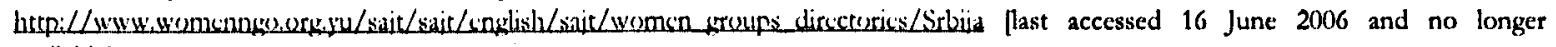
available].

${ }^{13}$ Autonomous Women's Center 'Mission and Goals' hetp://www.womenngo.org,yu [accessed 16 June 2006 and no longer available].

14 There is no empirical data that supports the claim of increased violence with the wars: but the perception that violence increased with the wars is dominant. Many reasons for this perception are given. Z. Mršević 'Belgrade's SOS Hotline for Women and Children Victims of Violence: A Report' in S. Gal and S. Kligman (eds.) Reprodkcing Gender. Politics, Publics, and Eureryday Life affer Saxialism (Princeton University Press, Princeton: New Jersey, 2000), p. 389, points to the 'rhetorical force' of the argument, in particular its 'effectiveness in mobilizing support, and its utility for securing grants'.

15 Interviews with Diana Miladnović, Legal Advisor, Autonomous Women's Centre, Belgrade, 11 March 2008; Lepa Mladjenović, Coordinator, Autonomous Women's Centre, Belgrade 27 March 2008; Adriana Zaharijević, Women in Black Activist, Bclgradc, 10 April 2008; Ivana Radović, ASATRA Anti Sex-trafficking Awareness Officer, Belgrade, 17 April 2008; Zorica Mrsević, Deputy Ombudsman for the Republic of Serbia, Belgrade, 30 April 2008; Jelena Višnjić, Coordinator, Voice of Difference, Belgrade, 10 May 2008; Biljana Stanković, Coordinator, Novi Sad Lesbian Organisation, Novi Sad, 29 May 2008; Dusica Popadić, Coordinator, Incest Tramua Centre, Belgrade, 28 July 2008. All talked about various pattems of masculinities during the $1990 \mathrm{~s}$, stressing that an aggressive, criminal image of masculinity dominated. Quotation from Nikolic-Ristanović Social Change, Gender and Violence;, p. 71.

16 V. Bozic 'The Post TV News Syndrome' in Peace Magazine War Rape: Letters from ex-Yugoslavia' retrieved from

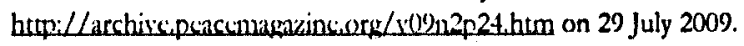


- War increased senses of inadequacy where men felt unable to meet hegemonic expectations of masculinities. Men who were refugees, who avoided the army, who were unemployed, and/or who felt unable to defend themselves during the 1999 NATO bombings, were sometimes noticed to be violent at home. ${ }^{18}$

- Activists noticed an increase in ethnically motivated domestic violence within inter-ethnic relationships (common in the Yugoslav period), as the man found his wife to be a source of social shame. ${ }^{19}$

Feminist activist analyses pointed to ways war produced particular images of masculinities, negatively affecting domestic violence. In short, it was believed that the war increased violence against women and created new terrors and new types of violences that women were subjected to'.20 In this way, a narrative emphasising the impact of war and conflict upon the type of domestic violence experienced was constructed.

War affected the framing of domestic violence concerns in Serbia. The dominant narrative presented by activists drew upon a structural discursive logic which connected violence against women with the patriarchal and violent wartime atmosphere surrounding them. Activists stressed how the outbreak of war in the early 1990 s meant that state institutions were increasingly unable and/or unwilling to deal with violence against women, and highlighted that war meant an alteration in images and expectations of masculinity, affecting the type of domestic violence experienced. That is to say, the emphasis is upon how war is linked to an increase in gender violence as a result of the wider social and political context that is product/productive of violence. The dominant discursive logic rests upon foundationalist assumptions emphasising how war changes structures of social and political life. This understanding drives critiques of social, political and institutional structures, stressing that they shape patterns of patriarchal violence in Serbia. That is, there is an understanding that war and conflict had a serious impact upon the patterns, prevalence and types of domestic violence in Serbia.

\footnotetext{
17 Mršević 'Belgrade's SOS Hotline for Women and Children Victims of Violence: A Report' , p. 387, L. Mladjenović and D. Matijašcvić 'SOS Belgrade July 1993 - 1995: Dirty Streets' in C. Corrin Women in a V'iolent W'orld (Tidinburgh University Press, Iidinburgh, 1996), p. 122, V. Nikolić-Ristanović 'Violence Against Women in Post-Communist Socictics: Benefits and Changes' Occasional Paper, Jast European Studies at the Woodrow Wilson International Center for Scholars (May 2001), p. 17, and V. Nikolic-Ristanović and M. Dokmanovic Intermational Stundards on Domestic Vialence and Their Implementation in the Westerm Balkans (Belgrade, 2006), pp. 29-30.
}

${ }^{18}$ Nikolic-Ristanović Sacial Change, Gender and V'iolene: p. 72-9.

19 Ibid, p. 90, J. P Kaufman and K.P. Williams Who Belongs? Women, Marriage and Citizenship: Gender Nationalism and the Balkan Wars' Intemalional Feminist Jowmal of Politics, Vol. 6, No. 3 (2004), pp. 416 - 435.

20 Mladjenović and Matijašcvić 'SOS Belgrade July 1993 - 1995: Dirty Streets' p. 120,127. S. Copic 'Wife Abuse in the Countries of Former Yugoslavia' Feminist Revicw No. 76, pp. 46 - 64 has limited data which suggests that wife abuse in Serbia increased with conflict and economic transitions. 


\section{Discursive Logics: (2) Institutions.}

Many activists view the "post-war problem" to be institutional inefficiency and unwillingness to deal with domestic violence, arising out of the disintegration of social and political values following violent conflict in the 1990s. However, as discussed in chapter three, the post-war era has also seen a rapid growth of activists interested in combating domestic violence, giving a broader range of gender politics. After the fall of Miloševic in October 2000, the subsequent increase in international funds for campaigns against domestic violence facilitated civil society growth. ${ }^{21}$ However, many activists feel that while concerns about domestic violence became more socially acceptable, connections made during the 1990s between the structural violence of the war system and domestic violence have been muted.22 Debates remain about the extent war and conflict shape the pattern of domestic violence in post-war Serbia. For some activists, domestic violence in Serbia remains connected to the consequences of social violence, war and nationalism. Many self-declared "political feminists" wrote a report in 2007 locating analysis of domestic violence within anti-war politics and a critical attitude towards the state. ${ }^{23}$ While virtually all groups interviewed had concerns about institutional efficiency, there is a difference in how groups frame their concerns. This section focuses upon the so-called "political feminists" who critique the state and stress the effects of war upon domestic violence.

Activists noted that the post-war era bought legal and structural gains in addressing domestic violence. In March 2002, the Criminal Code of Serbia was modified to introduce article 118a, recognising domestic violence as a specific form of violence. ${ }^{24}$ Prior to 2002 , there was no specific legislation addressing domestic violence in Serbia. ${ }^{25}$ These gains proved fragile in 2005 when the Criminal Code was altered to diminish penalties for committing domestic violence. ${ }^{26}$ NGOs begun to operate programmes supporting state institutions - including the Centres for Social Work, police, municipal prosecutors, and government departments - to increase effectiveness in dealing with

21 Westem financial support was important during the 1990s, especially to groups dealing with domestic violence concems, as discussed in Nikolic-Ristanović Sacial Change, Gender and Violence, p. 141 - 44. However, it is thought that the civil society development after the fall of Miloševic was more influenced by financial concerns, as firmly expressed by Duśica Popadić, Coordinater, Incest Trauma Centre, Bclgrade, Interview: 28 July 2008 and alluded to by other activists, who chose to remain off the record.

22 Interview. Duśica Popadić, Coordinator, Incest Trauma Centre, Belgrade 28 July 2008.

23 B. Branković and A. Lukić Allemative Reporl to the CEDAW Commitlee (Belgrade, 2007). Report distributed by Voice of Difference.

24 Ibid., p. 25.

25 M. Lukić 'Domestic Violence - Legal Solutions and Institutional Treatment' in V. Nikolić-Ristanović (ed.) Women's Rights and Social Transition in the FRJ (Center for Women's Studies, Research and Communication, Belgradc, 1997), pp. 118 - 120, Mršević 'Belgrade's SOS Hotline for Women and Children Victims of Violence: A Report', p. 382 - 384. Prior to 2002, a skilled lawyer could, in theory, work with the provisions relating to public violence or physical injury in the prosccution of domestic violence cases. In practice, this proved difficult.

${ }^{26}$ Branković and Lukić Allemative Report so the CEDAW Committee p. 28. These modifications may have been a result of a shift within Parliament and Government to the right following the 2004 elections. 
domestic violence cases.27 However, amongst "political feminists", there is frustration at the slowness of change, thought to be indicative of a lack of genuine will to deal with domestic violence. For example, institutions are thought to be unwilling to work with many NGOs, or reluctant to fund and initiate campaigns concerning violence against women..$^{28}$ Activists believe that state institutions do not prioritise dealing with domestic violence. ${ }^{29}$ While the post-war era has seen legal and structural gains in the fight against domestic violence, doubts remains about the extent that state institutions are sincere about these changes.

Feminist activists point to how particular social and political values result in the stagnation of institutional action in addressing domestic violence. While significant strides towards dealing with domestic violence have occurred, many activists feel that the state's attitude is 'contradictory', since local government are not prepared to make the required adjustments to the legal system. ${ }^{30}$ Activists from Women's Alternative Workshop, in Kikinda, a small town on the Serbian-Romanian border, asked their local judges in 2006 why the new Family Law (passed in 2005) had not been implemented. The judges replied that they could not implement the law because they had not been trained. ${ }^{31}$ The coordinator of the group, Biljana Iličic, felt that this was an indication of how,

There are laws that the courts are not implementing because they have to do a procedure of some kind, I mean, that is Vojislav Kostunica'. ${ }^{32}$

Kostunica, the Serbian President from 2000 - 3, and Prime Minister from 2004 - 8, the leader of the centre-right Democratic Party of Serbia, is viewed by some as being anti-progressive for his opposition toward Kosovo's independence and EU membership. In line with those perceptions, he

27 T. Ignjatović and B. Macanović 'Impact on the Policy Making Process' report retrieved from wrww.womungors on 10 July 2009.

28 Interviews with Jovanka Brikić, Women in Action, Velike Plana, 17 April 2008; Biljana Iličić, Nevanda and Vanda, Women's Altemative Workshop, Kikinda, 29 April 2008; and Radislavia Aralica and Ljiljana Matić, Zrenjanin Fducation Centre, Zrenjanin, 27 May 2008 , and Dusica Popadic, Coordinator, Incest 'Irauma Centre, Belgrade, 28 july 2008 all touched upon issues regarding the will of the state to work with NGOs on domestic violence concerns. See alșo Kulturni Centre DaMad, Novi Pazar, Project Report DPB 04-05/329/009 'Improving Women's I luman Rights in Sandžak' which highlights that the SOS Ilotline has been able to improve cooperation with the Centres for Social Work and local police, but not the Judiciary. Branković and Lukic Altemative Repurt to the CT:DAW" Commiltee, p. 15, 24 'suggests that the state does not financially support any campaigns conceming domestic violence. While the 2001 and 2002 Annual Reports of the AŽC 'Getting Stronger Opposing Violence' (Belgrade, 2001) and 'I'O Participate Actively and 'Together' (Belgrade 2002) do not show any indication of financial support from the state, the picture becomes more muddled after $2003 / 04$. In $2003 / 04$, $A \% \mathrm{C}$ was supported by the Ministry of Social Affairs of the Republic of Serbia - Fund for Social Innovations (Jet's Coordinate the Action, Belgrade, 2004, p. 18). The 2005 AZC Annual Report 'Collaborate to Bring Change' (Belgrade, 2005), p. 14 indicates that AZC was financially supported by the Ministry of Social Affairs of the Republic of Serbia - Fund for Social Innovations and the Ministry of Health of the Republic of Serbia. The sums of money involved are likely to be negligible. However, the list of donors in AŽC's 2007 annual report 'Spreading Promising

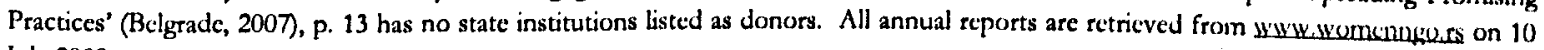
July 2009 .

20 Interview. Biljana Iličić and Nevana, Women's Altemative Workshop, Kikinda, 29 April 2008.

30 Interviews. Jovanka Brikić, Women in Action, Velike Plana, 17 April 2008; Biljana Iličić, Nevanda and Vanda, Women's Altemative Workshop, Kikinda, 29 April 2008; and Radislavia Aralica and Ljiljana Matić, Zrenjanin Education Centre, Zrenjanin, 27 May 2008.

3t Interview. Biljana Iličić, Coordinator, Women's Alternative Workshop, Kikinda, 29 April 2008.

32 Ibid. 
was thought to be dragging his feet over implementation of policies improving women's rights. By not setting the tone for appropriate action, activists feel that the political and social values promoted by certain politicians - like Vojislav Kostunica - have slowed down institutional changes at local level.

Nationalist politics is thought to affect the behaviour of institutions towards groups concerned with domestic violence. Since 2003, civil society organisations have been able to access Funds for Social Innovation grants (FSI grants), from the Serbian Ministry of Social Affairs. ${ }^{33}$ Politicised NGOs believe that FSI grants tend to support groups with a religious orientation, a perception that became more noticeable after the 2004 elections and the subsequent shift to the political right, as

in 2005 and 2006 humanitarian and traditionally-orientated organisations received greater funding (Ring of Serbian Sisters, Merhamet, the Bible League), while organisations that treat violence against women as human rights violations received little or no funding. We surmise that in this period, FSI has been under the influence of state structures, the policy of which, despite being declarative democratic, is really traditionalist and clericalist'. ${ }^{34}$

Activists also believe that nationalist politics mean that some groups are excluded from involvement in relevant local working groups. For example, Jovanka Brikić, the coordinator of Women in Action in Velike Plana, central Serbia, a group which believes that domestic violence is a political issue, realised that,

in our town a strategy [meeting] for social security took place, and there were representatives from all the other NGOs except us. Logically we should [have] participated as domestic violence [was on the agenda]. ${ }^{35}$

Jovanka believes that one reason Women in Action were excluded is because of their politicised stances: activists critique 'the state for being so slow'.36 The lack of support provided to certain groups enhances the beliefs held by so-called "political" feminists that the state does not want to talk about why domestic violence occurs; for example, connections to the violence of the 1990s, patriarchy, or nationalism. ${ }^{37}$ For some activists, institutional slowness and lack of support is a consequence of the nationalist structures of war politics.

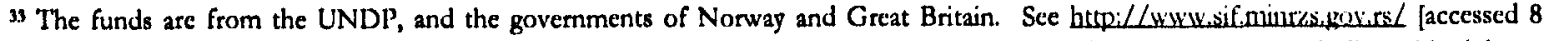
December 2009]. The Fund aims to developing local services in the social protection sphere -including programmes dealing with violence against women. 66 million has been invested since 2003.

${ }^{34}$ Branković and Lukić Allematite Report to the CEDAW Commiltee, p. 28. The groups mentioned are connected to the Serbian Orthodox Church.

3s Interview, Jovanka Brikić, Coordinator, Women in Action, Velike Plana, 17 April 2008.

36 Ibid.

37 Ibid.
} 
Gender politics affects how civil society actors perceive the actions of institutions concerned with violence against women. How the (post)war is conceptualised is woven into discourses about institutional efficiency. For example, Women's Alternative Workshop in Kikinda, Vojvodina, noted that;

'there were more donors in the region a couple years ago, and you could tell who is funding what area... but now they've just moved from the region, having the perception that everything is alright, but we don't think that things are just settled yet'. ${ }^{38}$

Things are not settled yet because wars 'don't just end'. ${ }^{39}$ For activists linking together conflict and post-conflict violence against women with institutional stagnation, Serbia is still facing problems caused by the wars and multiple transitions of the 1990s. Activists express concerns that Serbia is no longer attracting the international donor support that it needs in order for the civil society sector to flourish, but nor are issues concerning women's rights supported enough socially for the state to provide adequate support.

\section{Pulling the Trigger: SLAW and Domestic Violence.}

To assess how gender security concerns have affected the profile of the domestic violence debate in Serbia, it is necessary to focus upon one issue within the domestic violence agenda. Building on the broader context of the domestic violence debate already outlined, the focus of this chapter now moves to an in-depth analysis of bow and why SALW abuse concerns have risen further up the feminist agenda concerned with domestic violence in Serbia. The close focus on one issue allows more effective analysis of how gender security discourse altered the terrain. SALW abuse concerns were selected because the issue has connections to UNSCR 1325 and how post-conflict is problematised. To aid analysis later in this chapter, a predominantly descriptive account of advocacy work in Serbia related to concerns about SALW abuse in domestic violence is provided here.

'During the 1990 s, civil society actors highlighted the presence of SALW in domestic violence. After the start of the war, around $40 \%$ of women calling SOS Hotline reported that their partners were threatening them with pistols, bombs and similar weapons.40 Weapons were frequently kept as war souvenirs, and it was reported that men returning from the front were at times violent, tending to

\footnotetext{
38 Interview. Bijjana Iliččc, Coordinator, Women's Altcrnative Workshop, Kikinda, 29 April 2008.

"Enloe The Morming Afler. Sexwal Politics at the End of the Cold W'ar (University of Califomia Press, Berkeley, 1993) p. 2.

40 Mladjenović and Matijašević 'SOS Belgrade July 1993 - 1995: Dirty Strcets' p. 122; Nikolic-Ristanović Social Change, Gender and Violence p.
79.
} 
show their newly won hegemonic masculinity, often using weapons'.41 The increase in SALW circulation in the region during the early 1990s meant that for Lepa Mladjenovic, the coordinator of $A Z Z C$, 'the whole story about guns is a big story for violence against women, because it's connected to nationalism, to war, and the production of the enemy'.42 For Lepa, war meant an increase in SALW: a structural change producing a particular kind of violence against women connected to transitional insecurities. SALW issues continued to worry (some) activists in the apparent post-war era: in 1999 the Victimology Society proposed changes to the Criminal Code of Serbia, suggesting that applications to own a gun should be refused when a family member feels at increased risk. ${ }^{43}$ These legal changes were initially refused, but through highlighting connections between the post-war increase in SALW and domestic violence, civil society actors pointed to ways war altered domestic violence.

SALW issues in domestic violence were barely touched upon in Serbia until the end of 2007, when a report was published; Firearms Possession and Domestic Violence in the Western Balkans: A Comparative Study of Legislation and Implementation Mechanisms. The report was initiated by South-Eastern Europe Small Arms Clearinghouse (SEESAC), an agency mandated by the United Nations Development Programme (UNDP) and the Stability Pact for South-Eastern Europe (SPSEE). ${ }^{44}$ It was the first study specifically examining SALW abuse in domestic violence cases in the Western Balkans. Activists, particularly those involved with the Victimology Society of Serbia, have used the report to support concerns about SALW abuse in domestic violence. Much of the information put together drew upon the knowledge and expertise of feminist and gender-sensitive NGOs. ${ }^{45}$ The key findings of the report, for Serbia, indicated that;

\footnotetext{
${ }^{41}$ Branković and Lukić Allemative Report to the CEDAW Commilsee (Belgrade, 2007), p. 25. Nikolic-Ristanović Sacial Chunge, Gender and Vialena p. 97. See also Interview. Zorica Mrsević, Deputy Ombudsman for the Republic of Serbia, Belgrade, 30 April 2008.

42 Interview. Lepa Mladjenović, Coordinator, Autonomous Women's Centre Belgrade, 12 June 2009.

${ }^{43}$ Nikolic-Ristanović Social Change, Gender and Violence p. 159-60.

4 Until 28 February 2008, SEESAC was a joint project mandated by the UNDP and the Stability Pact for South-Eastern Europe (SPSEE). The SPSEE has since been succceded by the Regional Cooperation Council (RCC). While the concern of the SPSEE was to strengthen 'the efforts of the countries of South Eastem Europe in fostering peace, democracy, respect for human rights and economic prosperity', the RCC has a stronger focus upon Euro-Atlantic integration. See www.scessciorg; www.itabilitypactorn, and www, recint [accessed 14 December 2009]. SEESAC published the findings of the project in M. Dokmanović, Firearms Passession and Damestic Violence in the Westem Balkans: A Comparative Study of Legislation and Implementation Mechanisms (SEESAC, Belgrade, 2007). The Westem Balkans refers to Albania, Bosnia-Herzegovina, Croatia, FYR Macedonia, Kosovo, Montenegro and Serbia. The analysis in this chapter focuses entirely upon Serbia.

4s SEESAC 'SEESAC Strategy for Gender Issues in SLAW Control and AVPP Acrivities' (21 June 2007). Interview. Ivan Zveržhanovski, SEESAC Project Officer, Belgrade, 18 September 2009. 'Questions for representatives of women's NGOs' in Dokmanović, Firearms Passession and Domestic Vioknce in the Westerm Balkans, p. 67.
} 
- Higher numbers of SALW circulate the region, as a result of the wars, contributing to a sense of insecurity. ${ }^{40}$

- Awareness campaigns about domestic violence have been held by NGOs, but few campaigns have focussed on SALW concerns. ${ }^{47}$

- The law in relation to domestic violence and SALW has been poorly implemented, and relevant law enforcers are poorly trained about the dangers of small arms in domestic contexts.

- Access to SALW remains easy as there are no mental health or previous conviction checks. ${ }^{48}$

- There is no data on the prevalence of armed domestic violence, although women's and feminist NGOs acknowledge that it exists.49

Since the publication of the report, activists have devoted attention to raising the profile of SALW abuse in domestic violence by concentrating upon awareness-raising and coalition-building. The actions taken by NGOs - in particular the Victimology Society - between April 2008 and July 2009 are discussed in more detail at the end of this chapter. With support from international institutions (SEESAC) and INGOs like the International Action Network on Small Arms (IANSA), the Victimology Society has highlighted concerns about SALW abuse in domestic violence. Since 2007 there has been a growth in advocacy work connecting SALW abuse and domestic violence, in part because of support from international actors. The next section explores the role of international gender security discourse in pushing SALW abuse concerns higher up the domestic violence agenda in Serbia. The discursive logics framing the problematisation of domestic violence issues in Serbia suggest that perceptions of war and conflict affect the types of domestic violence that occurs, and the extent of institutional efficiency. As will become clear, the "post-conflict" context has been important in raising SALW issues: in part because the attention paid to SALW abuse in domestic violence by SEESAC arises out of broader intermational post-conflict development concerns. The connections discussed in this section, where feminist organisations during the 1990s specifically linked domestic violence to war-related violence in the region formed a base upon which concerns about armed domestic violence were related to the post-conflict context, supporting increased advocacy work on SALW abuse in domestic violence.

\footnotetext{
${ }^{46}$ Dokmanovic, Firearms Posserssion and Domestic V'iokence in the W'estem Balkuns, p. 3.

${ }^{47}$ Ibid., p. 16.

48 Ibid., pp. 16, 43-4.

49 Ibid., pp. 5-6.
} 


\section{INTERVENTION? INTERNATIONAL GENDER SECURITY DISCOURSE.}

These connections made by feminists during the 1990 s work in conjunction with the international context to raise awareness of SALW abuse in domestic violence. There is a consensus amongst scholars in International Relations that global concerns about domestic violence have increased. Social constructivist accounts describe an increasing global norm that gender violence should be dealt with by the international community, and hence, have increased funds for projects dealing with violence against women. ${ }^{50}$ In Russia, international actors like UNIFEM, the Ford Foundation and Open Society have funded gender violence issues, in response to a global feminist consensus to combat violence against women. ${ }^{51}$ Such accounts provide a critical and substantial explanation of how a discourse becomes effective. However, analysis of the construction of the discursive terrain, and the political impact of a specific discursive construction, is marginalised, leaving unanswered questions about why particular issues are further up an agenda than others. These questions are important when making sense of international action concerned with SALW abuse in domestic violence, as such issues are somewhat the Cinderella of the transnational women's movement concerned with gender violence. 52

Recent advocacy work linking SALW abuse and domestic violence is partly a result of increasing interest in the issue from international institutions: an interest derived from growing concerns about gender security. SEESAC was the main international institution in Serbia supporting capacitybuilding of advocacy work that linked SALW and domestic violence. SEESAC's work was supported by a range of interconnected UN directives, resolutions, agendas and mandates drawing upon configurations of gender security. These documents include, first, UNSCR 1325, a resolution urging for the gender mainstreaming of peace-keeping and peace-building processes, which has encouraged

so J. Joachim 'Shaping the Human Rights Agenda: The Case of Violence against Women' in M. K. Meycr and E. Prigl (eds.) Gender Politics in Global Gotemanct (Rowman and Littlefield, Londom, 1999), pp. 143-150. Other prominent constructivist accounts include M. E. Keck and K. Sikkink Activists Beyond Borders: Advocacy Networks in Intermutional Politics (Comell University Press, Ithaca, 1998) and J. Hemment Empouering Women in Russia: Activism, Aid, and NGOs (Indiana University Press, Bloomington, 2007), pp. 94 -5.

s1 J. E. Johnson Gender Violene in Russia: The Politics of Feminist Intenention, (Indiana University Press, Bloomington and Indianapolis, 2009) p. 3, 96. See also Hemment Empowering Women in Russia, pp. 94 -5, L. McIntosh Sundstrom Funding Civil Saciety: Foreign Arsistana and NGO Deselopment in Russia, (Stanford University Press, Stanford, 2006) and S. L. Henderson Building Democracy in Combemporary Russia: Westem Support for Grassroots Organisalions (Comell University Press, Ithaca, 2003).

32 Analysis by V. Farr 'The Impacts on Women of Prolific Small Arms and Light Weapons' Canadian Women's Sirdies, Vol. 22, No. 2 (2003), pp. 56 - 63 and 'A Gendered Analysis of International Agreements on Small Arms and Light Weapons' in V. Farr and K Gebre-Wold (eds.) Brief 24 Gender Perspectives on Small Arms and Light Weapons: Regional and International Concerms (Bonn International Centre for Conversion, Bonn, 2002), pp. 14 - 24, suggest that current SALW and gender mainstreaming within the UN do not make connections between SALW and gender violence explicit. Additionally, the UN General Assembly Declaration on the Elimination of Violence Against Women (A/RJS/48/104, 23 Fcbruary 1994) makes no reference to SALW violence against women, and virtually no academic work makes explicit connections between gender, SAI.W and domestic violence. Recognising that the domestic violence agenda embodies several issues, I believe that SALW abuse concerns are low on the overall domestic violence agenda. 
the UN system in post-conflict zones to consider gender. SEESAC is mandated by the UNDP to support post-conflict peace and development in South Eastern and Eastern Europe, and so the agency has been encouraged to take in consideration UNSCR $1325.5^{33}$ Second, the UNDP has supported and echoed the gender security language of UNSCR 1325 in its 'Eight Point Agenda' (8PA) for 'practical, positive outcomes for girls and women in crises'.54 The $8 \mathrm{PA}$, issued to all UNDP agencies in early 2007, emphasised gender mainstreaming. Following the 8PA, the UNDP recommended SEESAC dedicated at least $10-15 \%$ of their budget to gender issues. ${ }^{55}$ In support of the $8 \mathrm{PA}$, SEESAC produced a gender strategy in June 2007, forming the starting point for their gender mainstreaming activities.56 A discursive framework concerned with gender security has filtered through parts of the UN system, including SEESAC, allowing connections between SALW abuse and domestic violence to be emphasised.

Financial and logistical support by SEESAC enabled the production of a report drawing together existing knowledge and understanding about SALW and domestic violence in Serbia. SEESAC does not aim to conduct 'pure and strategic research', but rather, operational and evidence-based research: that is, there is no new knowledge. ${ }^{57}$ That there is no new knowledge is important, as it stresses that the issue of SALW abuse in domestic violence has been thrown into the limelight. A specific configuration of gender security has been productive of an increased concern with SALW abuse in domestic violence. This section explores how the perception of gender security put forward by SEESAC rests upon particular logics of international human security and gender mainstreaming. Understanding the dynamics of international discourses upon the contours of the domestic violence debate in Serbia gives insight into the framing of domestic violence concerns, indicating why more attention was paid to SALW abuse concerns. As Janet Elise Johnson found in her research 'on gender violence in Russia, 'gender politics [regarding domestic violence] is shaped by foreign intervention, [and so] this domestic gender analysis must be embedded in the global context'.58 This is also the case for Serbia: to understand how a concern with SALW abuse in domestic violence became more prominent, we need to understand the effects of international discourses.

\footnotetext{
53 SEESAC 'Mission Statement' and 'Background'; retrieved from wwisccsac.org [accessed 14 December 2009]. Intervicw. Ciara Loughney, (former) SALW Awareness Officer, Belgrade, 11 April 2008.

34 UNDP: Crisis Prevention and Recovery 'The Eight Point Agenda: Practical, positive outcomes for girls and women in crisis' herp://www undporg/epe/we do/8 pasthunl [accessed 12 July 2010].

ss Interview. Ciara Loughney, (former) SAI.W Awareness Officer, Belgrade, 11 April 2008.

so SEESAC 'SEESAC Strategy for Gender Issues in SI AW Control and AVPP Activities' (21 June 2007). AVPP refers to Armed Violence Prevention Programmes and Projects.

37 Ibid.

${ }^{38}$ Johnson Gender Violence in Ru.rsia, p. 7.
} 


\section{International Human Security.}

Human Security, as outlined in chapter two, is a security logic placing the individual at its ontological heart. That is, the primary concern of security is the individual human being as opposed to the state. Commentators supporting this perspective argue that relocating the subject of security so that it considers the individual enables different kinds of violences to be noticed. Such violences, for many, include domestic violence.59 Alongside increasing Human Security concerns has been the reinforcement of ideas about international security: the thought that "we" have a responsibility. 60 The notion of international security is heavily contested, as indicated in chapter two, but the essence of international security is that the world is a unified community with a shared sense of which violences to act against. International human security suggests that certain violences are portrayed as fundamental and universal human wrongs, and so should be dealt with by the international "community", which is viewed as a "conceptual domain that functions to provide security'.61 The idea that "we" have a responsibility to protect the security of individuals has emphasised the notion that violence against women is an international concern, making domestic violence an international human security discourse.

Discourses of human and/or international security have become increasingly emphasised within the United Nations (UN) system. While the UN has always been concerned with the maintenance of 'international peace and security', the early 1990s saw the emergence of a serious consideration about the concept of "Human Security" within the UN.62 Empirical analysis comparing UN Security Council and General Assembly statements in relation to the 1995 and 2004 UN missions in Haiti found that articulations of Human Security increased in the intervening decade. ${ }^{63}$ The UN's global development network, the UNDP - which mandates SEESAC - has stressed notions of human

3n Sec, for example J. A. Tickner Gender in Intemutional Relations: Feminist Perspectites on Including Glabal Security, p. 58, E. M. Blanchard 'Gender, International Relations, and the Development of Feminist Security Theory' in Signs: Jourmal of Women in Cullure and Soxiety Vol. 28, No. 4 (2003), p. 1296, C. Bunch 'A Feminist Human Rights Lens on Human Security' speech given at the National Council for Research on Women Annual Conference, May 2003. Centre for Women's Global Leadership, Rutgets, The State University of New Jersey. Retrieved from herpi//corghrutecrsicdu [accessed 28 August 2009].

so 'T. Dunne and N. Wheeler "'We the Peoples": Contending Discourses of Security in Human Rights Theory and Practice" Intermational. Relacions, Vol. 18, No. 1 (2004), pp. $9-23$.

${ }^{6}$ Quotation retrieved from L. J. Shepherd Gender, Violence and Securig: Discourse ar Practiae (Zed Books, London, 2008) p. 126.

${ }_{62}$ The preamble of the Charter of the United Nations asserts that one of the aims of the organisation is to 'unite our strcngth to maintain international peace and security". "l'he Charter of the Unitcd Nations' retricred from

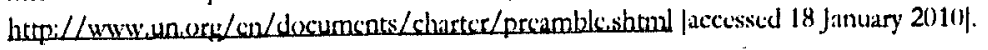

${ }^{63}$ R. Muggah and K. Krause 'A True Measure of Success? The Discourse and Practice of Human Security in Hait' in S. J. Maclean, D. R. Black and T. M. Shaw A Decade of Human Security: Globul Gotemance and New Multiluteralism (Ashgate, Aldershot, 2006), pp. 113 - 126. 
security since the publication of the 1994 Human Development Report: New Dimensions of Human Security.64 The UNDP's conceptualisation of security is viewed as complementary to, and mutually dependant upon, state security. Thus, the UNDP performs security in a different way to the Women in Black activists discussed in the previous chapter, where activists are urging for an overhaul of what we understand as "security". The UNDP - and its agencies - emphasise a vision of international human security that reasserts the importance of the role played by the state and the international community in securing individual security.

A vision of international human security stressing individual security protected by the state and international community contributed to increased concerns about SALW disarmament in SouthEastern Europe. Following the UN Small Arms Conference January 2000 - July 2001), a Programme of Action to Prevent, Combat and Eradicate the Illicit Trade in Small Arms and Light Weapons (POA) was agreed. ${ }^{65}$ The PoA was formulated to address concerns about the humanitarian impact of SALW, in particular the threat posed to 'peace, reconciliation, safety, security, stability and sustainable development at the individual, local, national, regional and international levels' from illicit SALW proliferation. ${ }^{66}$ The emphasis upon the humanitarian impact of SALW abuse has been the primary concern driving international action, framing SALW concerns as a human security issue. ${ }^{67}$ The $2001 \mathrm{PoA}$ developed and triggered several policy initiatives. One initiative, put forward by the SPSEE, supported the formulation of SEESAC in May 2002 under the auspices of the Regional Implementation Plan on Combating the Proliferations of SALW. ${ }^{68}$ An international concern with SALW-related human insecurity contributed to the establishment of SEESAC, a specific agency to deal with SALW disarmament and awareness-raising in South-Eastern Europe. That is, the discursive emphasis upon notions about international human security emphasised concerns about the humanitarian impact of SALW, simulating the establishment of SEESAC.

\footnotetext{
${ }^{64}$ United Nations Development Programme Ilumun Detelopment Report 1994: New Dimensions of Iluman Security (UNIDP, New York, 1994). For an outline of UNDP positions on Human Security, see Occasional Paper 5 R. Jolly and D. Basu Ray The Humun Security Frameswork and National Human Detelopment Repartr (UNDP, New York, 2006), pp. 4-7.

6s Programme of Action to Prevent, Combat and Eradicate the Illicit Trade in Small Arms and Light Weapons in All Its Aspects (UN

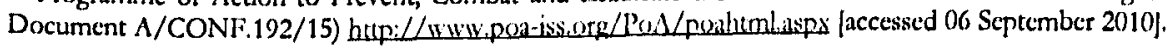

${ }^{6}$ Ibid.

${ }^{67}$ R. Muggah and E. Bcrman HIumanitarianism Under Tbreut: The Humanilurian Impacts of Small Ams and Light Weapons Special Report (Small Arms Survey, Geneva, July 2001), pp.vii - ix.

68 E. Laurance and R. Stohl Making Global Public Poligy: The Case of Smull Arms and Light Weapons Occasional Paper No. 7 (Small Arms Survey, Geneva, December 2002), p. 11. See also SEESAC 'About SEESAC' hup://wnwwscisacong/about-scessic/1/ laccessed 6 Scptember 2010].
} 
SEESAC is guided by a vision of human security emphasising long-term development and cooperation with relevant programmes and institutions. The central objective of SEESAC, outlined in its mission statement, is to "contribute to enhanced stability, security and development in South-Eastern and Eastern Europe'.69 Through linking development and security, security is equated with an improvement in quality of life. This is an inherently positive conceptualisation of security: security can transform lives. The security problem addressed by SEESAC spotlights SALW proliferation, which contributes to,

'threats from international terrorism; pervasive tegional instabilities such as the escalating, intensifying or prolonging of conflicts; impeding of humanitarian assistance; obstruction of postconflict reconstruction and development; and contribution to organised crime and human trafficking. ${ }^{70}$

Critical to the problematisation of SALW proliferation is a connection to a wide range of long-term insecurities. These long-term insecurities are best addressed through 'a strong regional framework by which international partners can work closely... on joint programmes to implement the existing European and international commitments and standards'.71 The stress upon regional and international cooperation reinforces the perception that cosmopolitan political communities are responsible for sccuring security. SEESAC's SALW concerns are framed by strongly normative configurations of human security: "we" need to protect individuals, "we" are responsible, and "we" can transform socicties.

These perceptions about human security within SEESAC shape the boundaries and limitations of how SEESAC subsequently considers gender security. The emphasis upon noticing SALW-related violence perpetuating conflict and crime feeds into a perception of gender security stressing the effects of SALIW proliferation and abuse. The ontological priority given to the international community in human sccurity suggests that, for SEESAC, the international community is also important in notions of gender security. That is, SEESAC's work on gender security has been influenced by the discourse of international human security. Noticing that SEESAC's conceptualisation of gender security has been shaped by the dominant ontology of Human Security is important as it means that SEESAC has a different security logic than Women in Black. The following paragraphs will highlight how the increasing international emphasis upon human security collided with increased gender mainstreaming concerns to highlight issues surrounding SALW abuse in domestic violence.

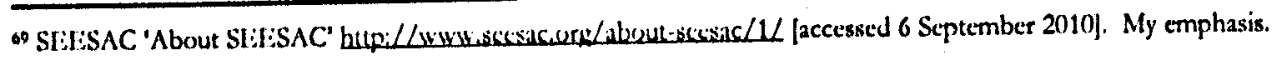

r SIILSAC 'Combating the Proliferation and Impact of Small Arms and light Weapons' Stability Pact for South Lastem Eurspe Regional Implementation Plan (Revised 2006). Retrieved from hup://wusisecsicura/abeut-sccsac/1/ accessed 6 September 2010] pp. $1-2$

"Ibid., p. 5.
} 


\section{International Gender Mainstreaming.}

Gender mainstreaming has been high on the international feminist political agenda since the fourth World Conference on Women, held in Beijing during 1995.72 Sally Baden and Anne-Marie Goetz

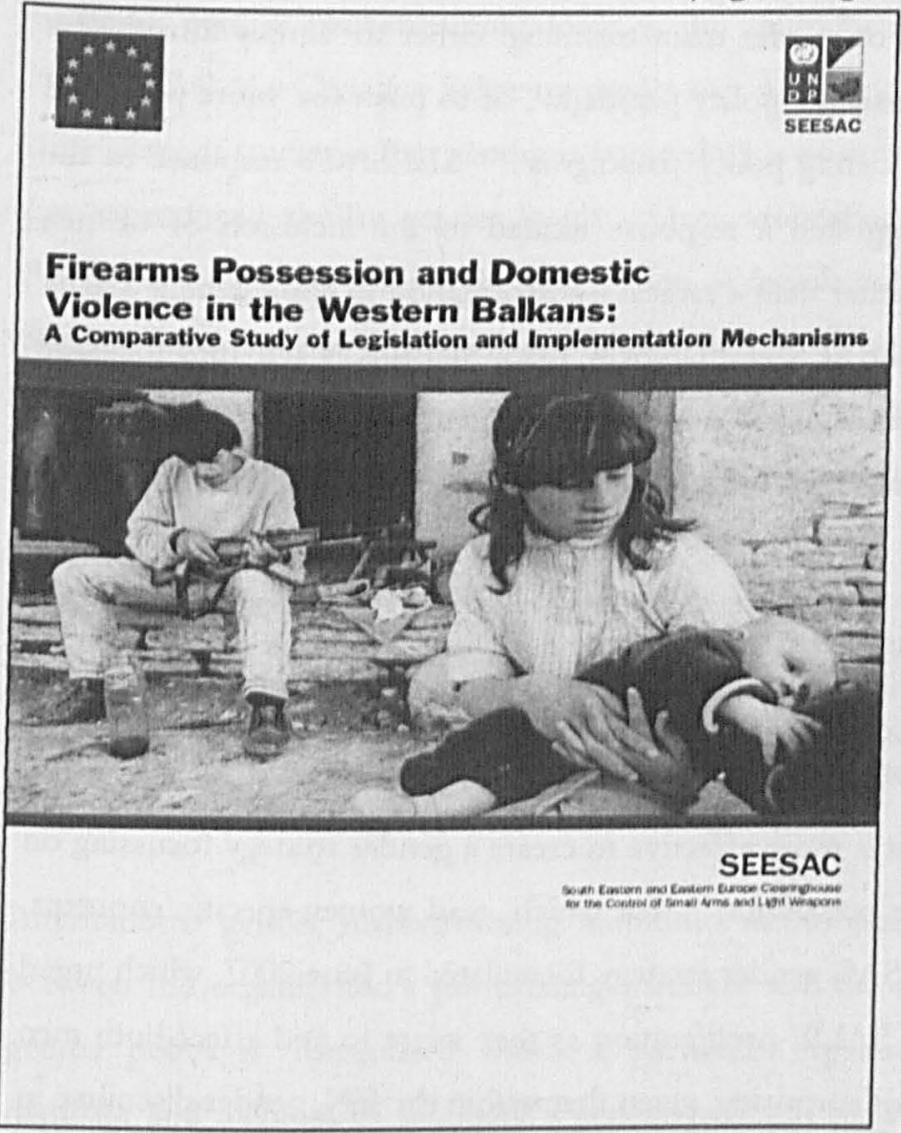

Image 6.1: Cover of SEESAC report Firearms Possession and Domestic Violence in the Western Balkans: A Comparative Study of Legislation and Implementation Mechanisms (SSESAC, Belgrade, 2007). Retrieved from www.seesac.org [accessed 3 March 2009].

define gender mainstreaming as a 'push towards systematic procedures and mechanisms within organisations particularly government and public institutions - for explicitly taking account of gender issues at all stages of policy-making and programme design and implementation', ${ }^{73}$ In other words, gender mainstreaming urges for consideration of "gender" within organisational and institutional policymaking. Some view gender mainstreaming as a radical equality strategy (in theory, at least) because of the focus upon challenging the 'structural reproduction of gender'. ${ }^{44}$ As a concept, process, and practice designed to achieve gender equality, gender mainstreaming is not without controversy: there is little consensus or clarity about the objectives and potential impact of gender mainstreaming. ${ }^{75}$

Controversies about gender mainstreaming centre on the interpretation of "gender" as a concept, and/or the desired effects of practicing mainstreaming: to integrate, to set the agenda, or to transform. ${ }^{76}$ Of particular relevance to this thesis is how institutions - like SEESAC - have

\footnotetext{
72 C. Moser and A. Moser 'Gender Mainstreaming Since Bejing: A Review of successes and limitations in international institutions' Gender and Development Vol. 13, No. 2 (2005), p. 11. ${ }^{73}$ S. Baden and A. M. Goetz 'Who Needs [Sex] When You Can Have [Gender]? Conflicting Discourses on Gender at Beijing' in Feminist
Review 56 (1997), p. 5 .

${ }^{74} \mathrm{~J}$. Squires Tbe New Politics of Gender Equality (Palgrave, London, 2007), p. 155 and 137.

${ }^{75}$ G. Waylen 'Transforming Global Governance: Challenges and Opportunities' in (eds.) S. M. Rai and G. Waylen Global Governance: Feminist Perspectives (Palgrave, 2008), pp. 259-60 and S. Walby 'Gender Mainstreaming: Productive Tensions Theory and Practice' Social Politics (2005)
p. 321.

76 Waylen 'Transforming Global Governance: Challenges and Opportunities', p. 260.
} 
constructed and utilised gender mainstreaming, and the impact that this has upon the configuration of gender security.

Questions remain about the desired effects of gender mainstreaming: either to 'simply introduce a gender perspective without challenging the existing policy paradigm', or to push for 'more profound change - transforming and re-orientating existing policy paradigms'.77 SEESAC's response to the demands of gender mainstreaming has suggested a response limited to the inclusion of women (where gender equates women) in SALW, tather than a radical transformation in approaching SALW concerns. Prior to the implementation of the 8PA and UNSCR 1325, SEESAC's activities focussed upon demobilisation and destruction: issues thought not to have a gendered aspect. ${ }^{78}$ When an explicit budget for gender concerns was established through the 8PA in 2007, a SEESAC official said that the agency's response was;

\footnotetext{
"'ok, we want to spend, we want to focus on gender", and we took ten percent... it's difficult in the heavy work like destruction and stop power management to include gender, so of course we would focus on the softer side of awareness and violence prevention'.7?
}

The quotation reveals the perception that it is more effective to create a gender strategy focussing on 'softer' issues like 'awareness and violence prevention' - for which, read women-specific concerns. This contradicts the ambitions of the SEESAC gender strategy formulated in June 2007, which urged for a 'dual approach' to address 'issues of SALW proliferation as they relate to and affect both men and women', ${ }^{80}$ These contradictions are not surprising, given that within the UN, gender discourse in relation to SALW is 'noticeably neglected' - making it more difficult to formulate a clear gender policy direction. ${ }^{81}$ The articulation of an international gender mainstreaming agenda has shaped SEESAC's funding policy, ensuring that resources are devoted to development of a gender policy. For SEESAC, the desired impact of gender mainstreaming is to focus on specific and separate concerns, rather than to integrate gender considerations throughout SEESAC's work.

$\pi$ lbid.

$n$ Of course, demobilisation and destruction of SAL.W are gendered issues; see M. Mackenzie 'Sccuritization and de-securitization: Female Soldiers and the rcconstruction of Women in Post-Conflict Sierra Leona' in L. Sjoberg (ed.) Gender and Internutional Secwrity: Feminist Perpectites (Routledge, London, 200\%), pp. 151 - 167 for an analysis of gender in DDR programmes. For gender and SALWW destruction, see M. Boume, W. Godwick, O. Grcen et. al. Retiesuing Action on Small Amr. Assessing the First Fite Yearr of the L'N progrumme of Action by Biting

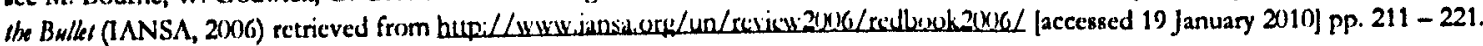

7Interview, Ciara Loughney, (former) SALW Awareness Officer, SLEESAC, Belgrade, 11 April 2008.

m SI:LSAC strategy for gender iskues in SAL.W control and AVPP activitics. June 2007.

"E. Schroeder and I. Newhouse Gender and Small Amms: Moting into she Mainstrewn Monograph No. 104 (2004) retrieved from wwiwiss,colean. [accessed 24 November 2008] pp. 5 - 6. 
A significant consideration in the process of implementing gender mainstreaming is how "gender" is constituted. Institutions seeking to achieve "gender mainstreaming" often interpret the process as an agenda about how to include women: male presence is limited to the 'background' of these policies, where men are frequently 'implied, and sometimes named, as the perpetrators' of violence. ${ }^{82} \mathrm{~A}$ common gender mainstreaming logic is the reproduction of gender as lazily synonymous with "women"'.83 As Christine Sylvester points out, a common observation amongst feminist scholars in development studies is that gender is equated with women. ${ }^{84}$ It is not surprising, per se, that SEESAC has reproduced similar gender logics. More interesting is the precise gender logic reproduced by SEESAC: a logic reinforcing the assumption of female vulnerability. The cover of the report Firearms Possession and Domestic Violence in the Western Balkans (image 6.1: above, left) depicts a young women holding a baby, with a man in the background cleaning a gun. Unwittingly, the image reinforces a gender logic of female vulnerability, and that women 'need/want/lack' support: international organisations should intervene to provide this support." While that 'people called women require gender-based support during times of conflict and violence is undoubtedly true', the vision of gender as female vulnerability serves to constrain the boundaries of action related to SALIW, and in particular shapes the very gendering of SALW concerns. ${ }^{86}$

International gender mainstreaming ambitions are limited by the necessity of negotiating a path between the organisation's pre-existing mandate and the newer desire to include gender. That is, gender policy is 'formulated within a particular organisational context, with specific pressures, mandate and ideology' ${ }^{87}$ SEESAC's gender policy is no exception: while the presence of UNSCR 1325 and the 8PA has simulated the formulation of a particular gender policy within SEESAC, how 7 the organisation considers gender is constrained by its mandate to demobilise and reduce SALW in South-Eastern Europe. ${ }^{88}$ The collision of various perceptions related to gender mainstreaming merge together to highlight SALW abuse in domestic violence cases. These perceptions include (1) the notion that, certain issues are not gender concerns while others are, and (2) that gender means women. Highlighting the subjectivities present in SEESAC's gender mainstreaming strategy is not to ${ }^{82} \mathrm{R}$. W. Connell 'Change among the Ciatckecpers: Men, Masculinities, and Cender liquality in the Global Arena' Signr: Journal of W'omen in
Cullure and Sarety (2005) vol. 30, no. 3, pp. $1805-6$.

${ }^{43}$ T. Carver Gender is not a Symunym for W'omen (London, I.ynne Rienner, 1996). HC. Sylvester 'Review of Shepherd, Laura J. Gender, Violence and Security: Discourse as Practice' Minenu. Joumul of Women und War Vol. 3 ,
No. $1(2009)$, p. 95.

"s Quotation retrieved from Shepherd Gender, Viokne and Security, p. 172.

*6 Sylvester 'Review of Shepherd, Laura J. Gender, Violence and Security: Discourse as Practice' p. 95.

"7 Moser and Moser 'Gender Mainstreaming since Beijing', p. 14.

A Interview with Ivan Zver’̌hanovski, SIELSAC Project Officer, Belgrade, 18 September 2009. 
say that concerns about SALW abuse within domestic violence are invalid or unimportant. Rather, the analysis enables recognition of the constructed nature of issues on the international agenda and the ways in which this agenda translates into specific and localised concerns.

\section{Making Discursive Contact: Gender, Security and Domestic Violence. ${ }^{89}$}

Increasing concerns about gender mainstreaming and human security have made discursive contact to push SALIW concerns higher up the domestic violence agenda. Human security discourses placing ontological priority upon configurations of international community as the means of resolving SALW concerns have worked in conjunction with SEESAC's vision for achieving gender mainstreaming to reproduce a specific logic of gender security. That is, the configuration of gender security underpinning concerns about SALW abuse within domestic violence cases in Serbia is product and productive of specific logics of human security and gender mainstreaming. The conceptualisation of gender security as a practice, or ambition, carried out by an international community concerned with protecting women who 'need/want/lack' support reflects a notion of gender security which Laura Shepherd believes is embedded within current conceptualisations of UNSCR 1325.90 Shepherd argues that the possibilities and constraints of UNSCR 1325 has been product and productive of a 'violent reproduction' of gender and the international, giving rise to a particular configuration of gender security. ${ }^{11}$ SEESAC's project connecting SALW proliferation concerns (an international human security issuc) and vulnerable women in need of protection (arising out of gender mainstreaming concerns) has also been product and productive of a reproduction of gender and the international. Highlighting the convergence of international discourses of human security and gender mainstreaming to configure particular visions of gender security develops an understanding of how the issue of SALW abuse within domestic violence has floated further up the activist agenda in Serbia.

The convergence of international human security and gender mainstreaming discourse within the performance of gender security discourse is critical. While, individually, "both SALW and gender mainstreaming in conflict prevention have found a prominent place on the international agenda', actual connections made between SALW and gender remain relatively weak. ${ }^{22}$ This is apparent through examination of UN documents relating to SALW: gender still 'goes entirely unremarked in all

\footnotetext{
19 'This aubheading is inspired by Shepherd Gender, Violene and Secuniy.

*) Shepherd Gender, L'iokence and Secxrity, pp. $161-172$.

9 lbid.

92 V. Fart 'The Impacts on Women of Prolific Small Arms and Light Weapons' Cumadian W'amen's Sindies, Vol. 22, No. 2 (2003) pp. 56 - 58.
} 
documents... not explicitly conceived to focus on gender mainstreaming.,93 Empirical analysis by Emily Schroader and Lauren Newhouse of the Security Council's thematic debates on women, peace, and security between 2000 and 2004 suggest that no reference to SALW was made during the debate in 2000 or 2001 , but by $2002,22 \%$ of statements referred to SLAW. ${ }^{44}$ While this focus is relatively minor in the context of other (post)conflict issues, Schroader and Newhouse feel that documents such as UNSCR 1325 have been 'instrumental' in pushing forward the gender effects of SALW on the international agenda. ${ }^{5}$ The implication is that without formal emphasis upon security or gender (for example, references to UNSCR 1325), the chances of noticing SALW concerns in relation to gender would be slim. Hence, convergence between gender mainstreaming and Human Security discourses, reproducing a particular logic of gender security, has been important in prioritising concerns about SALIW abuse in domestic violence.

SEESAC's conceptualisation of gender security is temporarily fixed through conceptualisations of international human security and gender mainstreaming. The central aim of SEESAC's gender mainstreaming strategy, articulated in May 2007, is to;

'support human security and sustainable development for families and broader communities by minimising the extent and impact of SALW misuse'.96

The phrasing of this statement connects gender concerns to human security and families. This is no accident, as SEESAC's gender strategy is partially inspired by UNSCR 1325, a document which, as Shepherd has argued, relies upon a 'violent reproduction' of discourses about the 'international' and 'gender'. ${ }^{77}$ UNSCR 1325 arguably places women as the "centralised significr in its discourses of gender' and women are 'fixed as vulnerable'. ${ }^{28}$ Hence, there is an implicit formulation of "women and children as victims of SLAW" reproduced within the Firearms Possession and Domestic Violence in the Westerm Balkans report. The discursive contact between gender, violence and security within the constitution of UNSCR 1325 is partially why armed domestic violence was the initial point of departure for SEESAC's gender mainstreaming ambitions: a point of departure local civil society activists picked up on. Ultimately, the particular conceptualisation of gender security offered by SEESAC opened up opportunities for activists to pursue concerns related to SALW abuse in domestic violence.

\footnotetext{
9.1/bid., p. 58.

24 Schroeder and Newhouse Ciender and Smull Arms: Moting into lhe Mluinsirreum, pp. 16 - 17.

9s lbid., p. 17.

* SEESAC 'SI:IESAC Strategy for Gender Issues in SI.AW Control and AVPP Activities" (21 Junc 2007), p. 1.

${ }^{77}$ Shepherd Gender, Violence and Secwrity, pp. $161-172$.

98 Ibid, p. 119.
} 
A brief mention of the "post-conflict" context is important as UNSCR 1325 was designed to operate in post-conflict situations, and the 8PA partially reflects post-conflict development concerns. The first part of this chapter highlighted how some activists made connections between post-conflict contexts and domestic violence, especially during the 1990s. Without the connections made by feminist organisations, specifically linking particular types of domestic violence and the apparent increase in SALW, to conflict and war-related violence in the region, it is difficult to relate concerns about armed domestic violence to post-conflict documents including UNSCR 1325 and the 8PA. However, discourses of "post-conflict" are relatively muted within public articulations of concerns about SALW abuse in domestic violence. This appears surprising given that "post-conflict" security discourse plays an important part in the construction of this issue. However, as explored in-depth later in this chapter, the downplaying of post-conflict discourses can be explained by the hostility of Serbian socicty to connections between gender and conflict. Despite ways that "post-conflict" discourses are restrained in the publicity concerning this particular issue, the activist discourse made between domestic violence and war - both in the past and present - was critical in enabling international support for raising awareness of SALW abuse in domestic violence.

The preceding paragraphs have illustrated that to make sense of how SALW abuse in domestic violence became a concern, we need to examine international discourses about human security and gender mainstreaming, and particularly look at how SEESAC have reproduced these discourses. The convergence of these discourses reproduced a particular configuration of gender security which stressed the importance of the international community in protecting vulnerable women. This particular conceptualisation of gender security meant that SEESAC, in aiming to implement UNSCR 1325 and the 8PA, highlighted the necessity of taking action to deal with concerns relating to SALW abuse in domestic violence. As noted earlier in this chapter, grassroots activists in Serbia made connections between conflict and domestic violence even during the 1990s, highlighting the prevalence of SALW abuse in domestic violence. However, to successfully push this issue further up the broader domestic violence agenda, a convergence between human security and gender mainstreaming discourses in the performance of gender security discourse has made possible (and limited) resources and political opportunities.

\section{USING "GENDER SECURITY"?}

The final section of this chapter locates the international discourses of gender security triggering SEESAC action within local actions carried out by activists concerned with gender violence in Serbia. That is, the spotlight moves back to civil society actions. While discourses of gender security are not 
made explicit in civil society actions relating to concerns about SALW abuse in domestic violence, gender security discourse has been central to creating opportunities for activists in Serbia. As argued in the previous section, gender concerns within international human security discourse has sharpened the focus upon particular issues, simulating the provision of tools to support advocacy work and encouraging new alliances and connections. However, NGO activists in Serbia have not explicitly articulated and represented these discourses of gender security in campaigns raising awareness of SALW abuse in domestic violence. The exclusion of explicit articulations and representations of gender security discourse within activist framings of concerns about SALW abuse can be explained by the gender politics surrounding the broader domestic violence agenda in Serbia. The first part of this section outlines the steps taken by NGO activists in Serbia between February 2008 and June 2009 to raise awareness of SALW abuse in domestic violence concerns, highlighting how SALW concerns moved higher up the activist agenda as a result of international gender security discourse. Attention then turns to a discussion of the gender politics embedded within the domestic violence debate, exploring why gender security discourse is not used to frame concerns about SALW abuse in domestic violence.

\section{Awareness- raising and Coalition-building.}

Initial actions after the December 2007 publication of the Firearms Possession and Domestic Violence in the Western Balkans report focussed upon awareness-raising and coalition-building: SEESAC expected civil society to raise awareness of the issue. The findings of the report were presented to a range of regional and local actors in early 2008.9 Participants in a Belgrade roundtable, held 8 May 2008, included a number of representatives from the Serbian Parliament and Government, judiciary and police, alongside civil society. ${ }^{100}$ SEES $\Lambda$ C's intention was for local actors to take the issues forward in the best possible way, believing that 'women's NGOs can make an important contribution to achieving this goal (of reducing the use of arms in domestic violence) by including the issue of SALWW control in their advocacy and lobbying activities'.101 While SEESAC provided the logistical support for activities, the onus was on interested local actors working together to prompt the desired changes. ${ }^{102}$ This strategy is dependant upon successful coalition-building and the ability to invoke existing networks. For example, the lead researcher for the report, Mirjana Dokmanovic, participated on a committee developing a Strategy against Domestic Violence, and she ensured the presence of

\footnotetext{
99 SLESAC ' SLESSAC Activity Report - AR/110 SIIISAC Roundtable on Fircarms and Domestic Violence Iegislation, Belgrade, Serbia, 8
May 2008' (15 May 2008).

100 Ibid.

101 Dokmanović, Finearms Parsession und Domestic Vioknce in the W"esterm Bulkans, p. ii.

102 Interview. Ciara Loughney, (former) SAI.W Awarencss Officer, Belgrade, 11 April 2008.
} 
SALW related issues within the strategy. ${ }^{103}$ SEESAC also provided funding for a legal consultant to draft recommended changes to Serbian law to tackle SALW abuse within domestic violence. ${ }^{104}$ The recommended legal changes drafted now form the centrepiece of the Victimology Society's campaigns connecting SALW abuse and domestic violence. Civil society actors have exploited the opportunities offered by SEESAC in capacity-building to push the specific issue of SALW abuse in domestic violence higher up the agenda.

Tracing the activities carried out by SEESAC and NGO activists in the spring and summer of 2008 suggest that actions in this area have increased. Actors have seized the political opportunities created by the convergence of international human security and gender mainstreaming discourses to reassert pre-existing concerns. As mentioned earlier, the Victimology Society had proposed changes to the Criminal Code of Serbia during 1998/99, calling for applications to own a gun to be refused when a family member felt at increased risk. ${ }^{1115}$ Victimology Society activists felt that they had not been able to pursue the issue further as a result of a lack of resources and interest during the late $1990 \mathrm{~s} .{ }^{106}$ Thus, when SEESAC commissioned the report, it was an opportunity to investigate the connections between SALW abuse and domestic violence, and to develop the capacity to push for a new initiative [concerned with] legal changes'.107 SEESAC had designed the project primarily as a baseline assessment and capacity-building project: in other words, to assess the situation, identify problems and support the ability of civil socicty actors to lobby for changes. ${ }^{108}$ SEESAC's ambition - to build civil socicty lobbying capacity - can be said to have been successful as activists from the Victimology Society concerned with the connections between SALW abuse and domestic violence have used the report and legal recommendations as a platform for their advocacy campaigns. sus 'This domestic violence strategy was formulated to guide the activitics of the Provincial government in Vojvodina, an autonomous
province in the north of Scrbia. Ciara Loughncy, SELSAC SALW Awareness Officer, Belgrade, 11 April and 20 June 2008, Marina lles,
Represcntative of Provincial Secretariat for Gender Lquality in Vojvodina, Novi Sad, 23 April 2008.

to4 Interviews Ciara Loughney, (former) SAI,W Awareness Officer, SEIESAC, Bclgrade, 20 June 2008, Vesna Nikolic-Ristanović, Discetor Victimology Society, Belgrade, $10 \mathrm{July} 2008$. The draft proposals for legal changes to the Criminal Code and Criminal Procedure Code of Serbia disscminated at the roundtable on $8 \mathrm{May} 2008$ is in the author's possession. Proposals include tightening the conditions requized to poskess a fircarms (for examplc, by conducting background checks for previous family violence convictions), harsher sanctions for the crime of domestic violence, and mandatory seizure of a weapon used in committing family violence.

105 Nikolic-Ristanović Sacial Chunge, Gender and Viokne, p. 159-60.

106 Interviews, Mitjana Dokmanović, Intemational Gender Consultant/Director Victimology Society, Subotica, 21 May 2008, Vesna Nikolic-Ristanović, Dircetor Victimology Society, Belgrade, 10 July 2008.

$1 m$ Interview, Mirjana Dokmanović, International Gender Consultant/Director Victimoloky Socicty, Subrotica, 21 May 2008.

10n All relevant SEESAC Activity reports including AR/107 and AR/110 indicate that the project fell into SEESAC's Operational Activity arca 1 - Capacity Building. See also interview with Ivan Zveř̉hanovski, SliESAC Project Officer, Belgrade, 18 Scptember 2009. 
The proposed legal changes formulated with the support of SEESAC have become the focus of a campaign coordinated between the Victimology Society of Serbia and International Action Network on Small Arms (IANSA). IANSA is an international network of civil society organisations working to 'stop the proliferation and misuse of SALW', 109 In June 2009, IANSA launched a worldwide campaign 'Disarm Domestic Violence': the Victimology Society of Scrbia is viewed as one of the ten 'core members' of the campaign. ${ }^{110}$ As part of this campaign, the Victimology Socicty organised an awareness-raising conference on 18 June 2009 to present the issue to representatives from the media, NGOs, the UN system in Serbia, and state institutions." ${ }^{11}$ IANSA has been important in supporting the Victimology Society in carrying out further advocacy work in highlighting SALW abuse in domestic violence. However, there is a gap between how IANSA frame concerns about SALW abuse in domestic violence, and how the Victimology Society publically frame similar concerns.

IANSA draws an explicit link between SALW violence and the gender security discourse embodied in UNSCR 1325 and UNSCR 1820. IANSA suggests that 'in order to fully implement UNSCR 1325, small arms policies and practice must include women in decision-making and take gender issues into account'.112 Additionally, IANSA reminds us that UNSCR 1325 demands the inclusion of local women's initiatives, and that 'measures need to be taken to support local women's small arms initiatives through increased capacity building, provision of resources, and funding'.113 Furthermore, during August 2009, IANSA contributed to an open letter for consideration at the Security Council Open Debate, including an insistence that SALW was considered within the context of UNSCR 1820 on Women, Peace, and Security. ${ }^{114}$ These connections made by IANSA, drawing upon UNSCR 1325 and 1820 demonstrate an explicit link between (international) human security discourse and the gender aspects of SALW. In contrast, the Victimology Society have not made explict references to gender security discourse in their advocacy work. While activists believe that UNSCR 1325 and

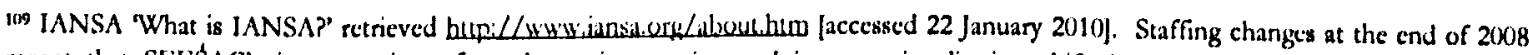
meant that SIESSAC's intepretation of gender mainstreaming and its operationalisation shifted, and as such, their work with the Victimology Society is no longer relevant to SIEISSAC's gender mainstreaming ambitions. Interview. Ivan Z Zerăhanoviki, SI:ISSAC Project Officer, Belgrade, 18 Scptember 2009.

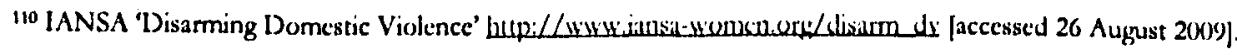

11' Victimology Socicty Press Release 'Manje Oružja u Kuči-Manje Nasilja! Globalna Kampanja Nedelja Borbe Protive Nasija Upotrebom Vatrenog Oružja' (licwer Weapons at llome - Less Violencel Global Campaign Combating Viulence Using Armed Weapons Weck)

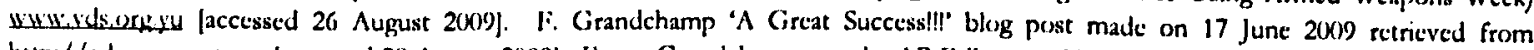

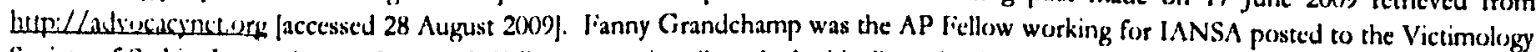
Socicty of Serbia, June - August 200\%. AP fellows are primarily tasked with disseminating information in Iinglish on behalf of the NGO for which they are working, and as part of the fellowship requirements, they are expected to maintain a comprchensive and accurate blog.

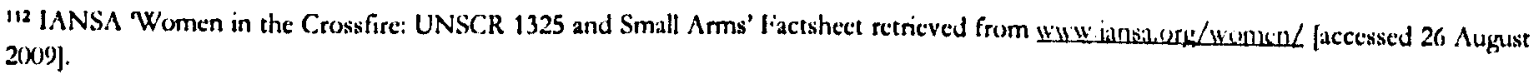

i13 Ibid.

"14 IANSA 'UN Security Council Open Debate on 1820 (2008)' [accessed 26 August 200\%].
} 
gender security discourse is 'very useful' for this campaign, it has not been used because of limited time and space."15 That is, in the eyes of the Victimology Society, UNSCR 1325 and/or gender security discourse is not deemed to be a useful way of getting attention.

While the Victimology Society does not explicitly use discourses of gender security, gender security discourse, as indicated in the previous section, has been important in raising the profile of concerns about SALW abuse in domestic violence. The gender mainstreaming ambitions of SEESAC and the wish of IANSA to utilise UNSCR 1325 in their advocacy work has created opportunities for the Victimology Society to push forward concerns about SALW abuse in domestic violence. This is another way of thinking about discourse: discourses can affect practice even where it is not immediatcly obvious or explicit. The actions taken by the Victimology Society during 2008 and 2009 in relation to SALW abuse in domestic violence arise from the sedimentation of a range of overlapping discursive logics related to international gender mainstreaming, international human security, gender security, and UNSCR 1325. That is, within discourses of gender security (reproduced within UNSCR 1325), where gender is imagined as vulnerable women in need of support, and the perception of human security as one where "we" should take action, has prompted and triggered international action to push for "gender security". Thus conceptualised, "gender security", when practiced by international organisations concerned with SALW disarmament has translated into a concern with SALW abuse within domestic violence. This has created opportunities for local actors - like the Victimology Society - to pursue these concerns. Digging deeper and going beyond the explicit articulations and representations of gender security discourse reveals influences and traces of gender security discourse, highlighting the potentially powerful effect that discourses of "gender security" can have.

\section{Gender Politics and Security Discourse.}

Many activists and leaders working to combat domestic violence make connections between domestic violence and security discourse. As noted in chapter four, most activists cited gender violence as a security concern. These connections are not surprising, as if you look at definitions of human security, there is no better paradigm for human insecurity than violence against women, which directly and indirectly affects a vast number of people'.116 Certainly, Zorica Mršević, speaking with over twenty years of experience with gender issues; as a feminist activist, a researcher, within international institutions and now working for the Serbian Government, observes that the concept of

is Interview, Jasmina Nikolić, Victimology Socicty, Belgrade, 18 Scptember 2009.

116 Bunch 'A Feminist Human Rights Lens on Human Security' 
security has, to an extent, 'matured and developed' amongst feminists concerned with domestic violence. ${ }^{117}$ However, these connections between domestic violence and security tend to remain theoretical and 'not really understood and not really implemented in practice'.118 These thoughts are echoed by Lepa Mladjenović, the coordinator of AŽC, who points out that the AŽC 'talk more about sigurnost (safety). But if I think twice, bezbednost (security) is the better word... but [sigumost] is in the language of women"119 While an activist signification of "gender security" generally includes domestic violence, the discourse of "gender security" has not played a part in activist framings of campaigns to combat and challenge any aspect of domestic violence.

If significations of gender security tend to include domestic violence, this raises questions about why security discourse is not explicitly articulated in NGO campaigns making connections between SALW abuse and domestic violence, even though the practice of "gender security" discourse has been critical in pushing the issue higher up the feminist agenda. To make sense of why gender security discourses are not explicitly articulated, it is necessary to bring together several perceptions. First, understanding the range of gender politics surrounding the domestic violence debate in Serbia, and how these gender politics are limited and made possible by personal-political imaginations of conflict and post-conflict reconstruction. These issues were discussed earlier in this chapter, and in chapter four. It was pointed out that understanding domestic violence as connected to violence in society (such as wartime and post-war violence) is considered to be a profoundly political position. Second, the realisation that configurations of gender security driving forward concerns about SALW abuse in domestic violence rests upon a particular logic of female vulnerability in need of protection from the international community. This logic does not challenge or problematise the future of post-conflict reconstruction in the way that activists from Women in Black aim to, as discussed in chapter five. Thus, domestic violence concerns can be raised without reference to socially unpopular debates about Serbia's position in relation to war and post-war reconstruction. These points can be drawn together to suggest that there is a relationship between gender politics and the signification, articulation and representation of gender security discourse.

Discourses of gender security did not need to be articulated and represented in activist framings of SALW abuse in domestic violence, as there is a strong social consensus supporting domestic violence

\footnotetext{
117 Intervicw. Zorica Mrsević, B.Igrade, 30 April 2008. Prof. Mrsevic was working as a Gender Advisor for the OSCl: when the author intervicwed her in Apri 2008. She now works as the Deputy Ombudsman for the Republic of Serbia

118 Interview. Zorica Mrsević, Deputy Ombudsman for the Republic of Serbia, Belgrade, 9 June 2009.

119 Interview. L.epa Mladjenović, coordinator, Autonomous Women's Centre Bclgrade, 12 June 2009. For more on the differences between sigumost and beabednart please see chapter four.
} 
concerns, in comparison to the feminist-pacifist issues. Jovanka Brikic, the coordinator of Women in Action, often wishes that she could speak out about issues relating to political responsibility, but as she lives in Velika Plana, a small town in central Serbia, she feels 'silent and invisible' and so she concentrates upon concerns about domestic violence which is more benign, because there is social consensus about this issue'. ${ }^{120}$ Society is more ready to accept domestic violence concerns, in part because it can be framed differently. Since domestic violence is frequently framed as an issue of human rights and bodily harm, it is a concern upon which broad coalitions can be built around. ${ }^{121}$ The relative social consensus on issues relating to domestic violence means that the articulation and representation of security discourse is not necessary for successfully achieving activist objectives in challenging domestic violence.

The relative social acceptability of domestic violence concerns in Serbia - in comparison with feminist-pacifism - is partly because it is possible to address domestic violence without dealing with the unpopular political responsibility questions. While SALW abuse in domestic violence is connected to a broader post-war context (by highlighting high levels of gun ownership following conflict), questions about Serbia's relationship to the wars of the 1990s are not touched upon. That is, personal-political imaginations of conflict and post-conflict are presented in a particular way when discussing domestic violence, to ensure that legal and social changes can be achieved. In essence, understanding gender politics in Serbia is critical to understanding how and why security discourse are (not) used. Chapter three highlighted how, in Serbia, personal-political imaginations of conflict and post-conflict have a significant impact on how gender and feminism is viewed, shaping the gender politics of activists. These gender politics affect how security discourse is used, where security discourse relates to conflict and post-conflict concerns. Even though SALW abuse in domestic violence cases in Serbia have been linked to the consequences of the wars of the 1990s, highlighting this connection has only been politically useful within international contexts to attract logistical and financial support. To successfully achieve the objective of building coalitions to campaign for tighter laws in Serbia relating to domestic violence and gun ownership, it is not necessary to frame the concern as a post-conflict insecurity issue.

The effects of gender security discourse has become more noticeable since UNSCR 1325 was passed. However, the impact of UNSCR 1325 in the articulation and representation of SALW abuse in

120 Interview. Jovanka Brikic, Coordinatos, Women in Action. Velike Plana, 17 April 2008. This comment has already been mentioned in this thesix, but it is expecially illustrative of the difficulties faced by some activists.

121 Keck and Sikkink Aititists Beyond Bounders, pp. 165 - 198; Sundstrom Fiznding Ciril Saciey, p. 97, C. Bunch 'Women's Rights as Human Rights: 'Toward a Revision of Iluman Rights' Human Rights Qwarterly Vol. 12 (1990), pp. 486 - 28. 
domestic violence concerns is limited as activists are not aiming to reinterpret or rethink the dominant framing of the resolution. The reproduction of gender and the international that is product and productive of UNSCR 1325 is in itself successful in opening up opportunities and resources to raise the profile of SALW abuse concerns. ${ }^{122}$ Security discourse is rarely called upon, because for many activists working on domestic violence concerns, the discursive connections between domestic violence and security remain weak. While many activists cite gender violence as a security concern, awareness and understanding of the discursive potential of gender security is limited amongst NGOs concerned primarily with domestic violence. ${ }^{123}$ In contrast, Women in Black activists, as discussed in chapter five, had the space to deliberate upon the discourse of security and how it could be conceptualised in a particular way so that the discourse would be useful for their objectives. Logistical or financial support to create a space for reflection upon "gender security" has not yet been provided to activists working on domestic violence concerns. 124 The lack of a 'room of one's own' for activists to consider how gender security discourses and UNSCR 1325 could relate to domestic violence has meant dominant performances of "gender security" within UNSCR 1325 are left unchallenged.

Very different motivations lie behind the utilisation of UNSCR 1325 and the gender security discourses that are product and productive of the resolution. For activists working on SALIW abuse in domestic violence concerns, the potential of UNSCR 1325 was connected to ways that the resolution played a part in opening up opportunities to push specific concerns further up the agenda. Women in Black activists also saw the potential of UNSCR 1325 in highlighting their feminist-pacifist ambitions. However, as argued in chapter five, it was necessary for activists to have a space for reflection upon UNSCR 1325 and gender security discourse to reconceptualise and reframe meanings of "gender security" so it fitted in with their objectives. Women in Black activists are aiming to challenge what they view as dominant structures of militarism in society, and so activists connect this ambition to security discourse. In contrast, while activists primarily concerned with domestic violence may also question perceived foundations of society, this is not their primary concern. Activists working on domestic violence have different political priorities and therefore operate within contemporary boundaries of limitations and opportunitics. That activists concerned with SALW abuse in domestic violence do not explicitly articulate and represent discourses of gender security in their campaigns (despite gender security being useful in opening up opportunities to work on the issue) is revealing of the impact that gender politics has.

\footnotetext{
122 Shephord Genckr, Liulence and Secwrig.

123 Intervicw. Lepa Mladjenović, coordinator, Autonomous Women's Centre Belgrade, 12 June 2(0)9. I.cpa suggests that many activists are not aware of what "gender security" could mean, and how it could relate to domestic violence.

${ }^{24}$ Interview, Mirjana Dokmanovic, International Gender Consultant/Director Victimology Socicty, Subotica, 3 June 2009.
} 


\section{CONCLUSIONS}

The expansion of what we understand as 'security' by academics, policy-makers and activists has meant that we have begun to consider how SALW disarmament - an issue that is rarely gendered might have a gender dimension. The first part of this chapter sketched the key issues and tensions within the domestic violence debate in Serbia, indicating that SALW abuse concerns only made any kind of tangible impact from 2007 onwards, with logistical support from international actors like SEESAC and IANSA. The investigation of the role that international discourses played in supporting the resurgence of concerns about SALW abuse within domestic violence, undertaken in the second part of this chapter, illustrated that international concerns with "gender security" are product and productive of specific conceptualisations of (international) gender mainstreaming and human security. These international discourses have converged to craft a logic of gender security imagined as vulnerable women in need of support from the international community. By holding this particular logic of gender security, SEESAC, a UNDP agency concerned with SALW disarmament begun to focus upon SALW abuse concerns within domestic violence, opening up opportunities for activists from the Victimology Society to reassert their pre-existing concerns.

The performance of security discourse explored in this chapter is very different to the performance of security discussed in chapter five. While both performances of security draw upon critical logics of human security, placing a concern with the individual at its ontological heart, the gender logics invoked differs, shaping the performance of security discourse. The conceptualisation of gender security demanded by Women in Black is a deliberate and highly politicised reconceptualisation. In contrast, within domestic violence debates, security discourse was important for opening up opportunities for activists. The articulation and representation of gender security discourse need not be explicit: 'discourse incorporates material as well as ideational factors'. ${ }^{125}$ As discussed in the final section of this chapter, the divergences in the articulation and representation of gender security discourse are indicative of the gender politics driving practices of "gender security". In imagining the post-war gendered subject as vulnerable women in need of help, sticky questions about the direction of gender and post-conflict reconstruction in Serbia can be downplayed. These gender politics, relating to personal-political imaginations of war, conflict and post-conflict reconstruction, shape gender security discourse.

125 Hansen Security As Pnutice, p. 17. 


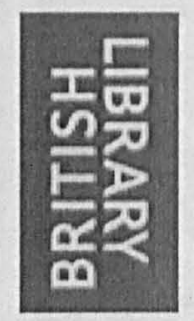

\section{IMAGING SERVICES NORTH}

Boston Spa, Wetherby

West Yorkshire, LS23 7BQ

www.bl.uk

MISSING PAGE/PAGES HAVE NO CONTENT 


\section{CONCLUSIONS.}

Throughout this study, in asking how feminist and women's organisations in Serbia have configured "gender security", I have maintained a sense of instability in addressing a "meaning" of gender security. In concluding this study, I refuse to 'fix' a definition, a concept or notion of "gender security", not least because 'a reconceptualization will simply reproduce the problems inherent in the concepts as they are currently configured. Any attempt at defining a concept necessarily 'fixes' that concept, at least temporarily, and... it is precisely this 'fixing' that is part of the problem'.1 Instead, I aim to contextualise the three problematisations flagged up in the introduction within the material discussed in this thesis. These themes included (1) the notion that "gender security" is a discourse, and therefore the way in which it is conceptualised is political; (2) the realisation that "post-conflict" is a potentially problematic zoning; and finally, (3) that gender politics - how feminism and gender is conceived by actors - has an influence upon the practice of "gender security". Discussion of these problematisations will highlight the possibilities for how we might go about thinking, investigating, and/or making sense of international politics. As a consequence, the refusal to fix "gender security" opens up a broader range of questions about how we interrogate international politics in a feministpoststructural way.

In this concluding section, I will first suggest that it is useful to see the competing modes of thought about "gender security" as constitutive of ontological identities about security. Contextualising the case studics investigated in chapters five and six of this thesis within the emerging project for a National Action Plan (NAP) to implement UNSCR 1325 in Serbia will expose some of the different logics of "gender security" that are possible. Second, attention then moves onto a consideration of how we "make" gender security. This section will address the importance of personal-political imaginations in making a gender security policy, highlighting an alternative understanding of policymaking in international politics, emphasising the importance of personal experiences in conceptualising the political. The third section picks up on the problematisation of gender and postconflict to highlight avenues for future research. Finally, I argue that the framework utilised to understand the politics of "gender security" in Serbia - reading the text of personal-political imaginations that are bound and made possible by various temporalities - offers an innovative way

1L. J. Shopherd Gender, Violene and Secwrig: Distowrse as Prustice (Zed Books, London, 2008), p. 172. 
forward for thinking about how international politics can be (and is) crafted through experiences, perceptions and hopes.

\section{GENDER SECURITY: COMPETING MODES OF THOUGHT.}

This study opened with an anecdote from Sead Biberović, an activist from Novi Pazar, south-west Serbia. He expressed the notion that 'security' is becoming a buzzword: indeed, the case studies deployed in chapters five and six suggest that one reason activists are producing and/or reproducing notions about "gender security" is in response to UNSCR 1325. However, as this thesis has demonstrated, there is no clarity yet about what the achievement of "gender security" looks like: that is, there are competing modes of thought about gender security. Exposing the gender politics underpinning configurations of "gender security" suggests that it is more useful to think of gender security as constitutive of ontological identities. By "ontological identities", I mean what individuals understand as existing and being in outlines of their sense of identity and self. Recognising the ontological identity present in a particular vision of "gender security" reasserts the constructed nature of "gender security" and how it is crafted through senses of being and existence. The focus on the effects of ontology echoes points made in chapter two, which organised competing visions of security through shared ontological logics about the referent subject of security. To explore the perception that achieving "gender security" is governed by competing modes of thought shaped by ontological identities, I will briefly discuss the project secking to develop a National Action Plan (NAP) for the implementation of UNSCR 1325 in Serbia. This project is discussed because it is one of the contexts which activists have played a part in conveying their perception of what "gender security" looks like in relation to UNSCR 1325.

In April 2010, the non-profit, non-partisan organisation, the Belgrade Fund for Political Excellence (BFPE) published a series of recommendations for drafting a N $A P$ for the implementation of UNSCR $1325^{\prime}$ in Serbia. ${ }^{2}$ The BFPE initiative was supported by the Serbian Ministry of Defence, with recommendations written by representatives of the Serbian Parliament, state administration, some NGOs, academics and journalists. ${ }^{3}$ The recommendations were initially formed in a series of working group meetings held between May 2009 and March 2010.4 The draft NAP particularly emphasises the role of women in decision-making processes relating to defence and security, legal

\footnotetext{
2 Belgrade Fund for Political lixcellence United Nations Secwrity Cauncil Rerolution 1325 in Serbia - On W'omen, Peane and Security (Belgrade Fund for Political Excellence, April 2010).

${ }^{3}$ Ibid., p. 8 . Intervicw. Programme coordinator, Belgrade Fund for Political Iixcellence, (Bcigrade, 8 June 20(0)). Fmail correspondence, 12 - 13
October 2(009; March 222010.
} 
protection of women during conflicts, gender-mainstreaming of the Serbian armed forces, and integrating gender in security sector reform policy.5 The security discourse within this initiative is based around a discourse of human security, and perceives Serbia to be both a post-conflict zone and a future player in external military-based peacekecping operations. ${ }^{6}$ The gender politics underpinning these ideas equate gender with women, and equate gender mainstreaming to bringing more women into operation.

Women in Black, the feminist-pacifist organisation that was the subject of chapter five, were invited to participate in the working group meetings for the NAP initiative during 2009. Activists from Women in Black were dissatisfied with the interpretation of UNSCR 1325 within the NAP initiative, arguing that the resolution's potential had been diluted. ${ }^{7}$ It was felt that the resolution was being 'reduced to a rhetorical level, to a formal level, without any link with the realities that we face in Serbia's As explored in chapter five, Women in Black's gender politics centre on political responsibility and feminist-antimilitarism, and as such, activists believe that these issues are critical for successful implementation of UNSCR 1325 in Serbia. Women in Black activists argue that the proposed NAP reproduces an 'uncritical implementation of the liberal, developmental and militaristic approach of security and gender.? For instance, the NAP focuses upon measurable and quota-based indicators of the participation and involvement of women in the Serbian armed forces. ${ }^{10}$ For Women in Black, this fails to raise questions about the necessity of the armed forces. ${ }^{11}$ Another critique put forward by Women in Black about the draft NAP is the failure of the document to address issues surrounding the political responsibility project.12 In contrast, most of the actors working towards the draft NAP for the implementation of UNSCR 1325 in Serbia do not necessarily sce political responsibility issues as relevant or important for successful execution of the resolution. ${ }^{13}$

B Belgrade Fund for Political lixcellence ('nited Nutions Secwrity Council Resolution 1925 in Serbia

- Interview. Programme coordinator, Belgrade liund for Political lixcellence, Belgrade, 8 June 2009, see also conference programme 'Implementation of UNSCR 1325 in Serbia' Kovacica, Serbia, 22 - 24 May 2009. In author's possession.

7 Interview. Staša Zajović, coordinator, Women in Black, Belgrade, 18 September 2009. Email correspondence, Maja Pesić 25 August 2009.

- Interview. Staša Zajović, coordinator, Women in Black, Belgrade, 18 September 2009.

- Women in Black 'Women in Black Activities and Important Documents Related to the Implementation of the Resolution 1325' Report, March 2010. hupi/Lurviacusucmum.ers [accessed July 26 2010], p. 2

10 Belgrade Fund for Political lixccllence United Nalions Security Council Resolution 1325 in Serbia - On W'omen. Peace and Security (Belgrade Fund for Political Excellence, April 2010), pp. 15 - 6.

11 Women in Black 'Women in Black Activitics and Important Documents Related to the Implementation of the Resolution 1325 ', Pp. 8 9.

12 Ibid., p. 4.

13 Interview. Programme coordinator, Belgrade Fund for Political Excellence, Belgrade, 8 June 2009, UNIFLM Serbia representative, Cender Advisor, Belgrade, 15 September 2009. 
The tensions concerning the specific constitution of a NAP for the implementation of UNSCR 1325 in Serbia illustrates how the politics of interpreting UNSCR 1325 is fraught with difficulties. This is because of the interpretations of gender politics (how gender is thought about) and security discourse (how security is articulated and represented) in relation to the resolution. These configurations of gender and security combine to give a particular logic of gender security. The range of competing views about how best to achieve "gender security" lends itself to the suggestion that securing security verges upon the impossible, given that security 'is always to come'.14 Certainly, analysis in this thesis serves to reveal the complexity of gender security - a seemingly narrow and clear concept. Through comparing and contrasting the discursive positioning, articulation and representation of gender security discourse and how it relates to UNSCR 1325 in both case studies, the political nature of "gender security" is illuminated.

Chapter two, which fleshed out the notion of security as a discourse, makes the point that there are several different logics underpinning individual/international security, which can be placed in two broadly competing categories. Individual/international security makes the referent subject of security the individual human being, but has different ways in which the "international" functions to provide security. In chapter two, we saw that Human Security approaches utilise a foundationalist ontology emphasising the ability of an international community of sovereign states to provide security, while Critical Security approaches challenge the neoliberal foundations of state sovereignty, urging for a vision of individual security based upon morality and emancipation. These competing visions for how to achieve "security" are reflected in debates about how to achieve "gender security". The ontological logics underpinning these conceptualisations of individual/international security can be identified in the case studies discussed in chapters five and six. Actors in both case studics have made a specific reading of UNSCR 1325 that is constitutive of their ontological identity. For instance, in chapter five, where the feminist-pacifist debate was investigated, activists from Women in Black utilised, UNSCR 1325 as a tool to support a critical conceptualisation of gender security concerned with emancipation from militarist and nationalistic structures that allow gender inequality in Serbia to endure. The vision of gender security put forward by Women in Black reflects many of the ontological assumptions underpinning Critical Security Studies approaches.

In contrast, chapter six, which investigated the growth of concerns about SALW abuse within domestic violence, activists have reproduced the conceptualisation of gender security that is product 14 J. E:dkins 'After the subjcet of Intemational Security' in A. Finlayson and J. Valentine (eds.) Politics and Post-Sirnitrnalism (Edinburgh
University Press, Edinburgh, 2002), p. 80 . 
and productive of UNSCR 1325. Gender security is envisaged as a notion which seeks to protect (biological) women who are in need of protection, a protection initially offered through the international community. The assumption of gender security put forward by SEESAC, reproduced by activists from the Victimology Society, echoes the ontological logics of Human Security approaches. Both visions of gender security discussed in chapters five and six are concerned with making the referent subject of security a gendered individual (whatever gender might look like) and question the assumed primacy of state sovereignty as a provider of security. To understand how these visions of security are different, it is useful to look at the ontological identity of a particular configuration of "gender security": what individuals understand as existing and being in their sense of identity and self. That is, questions about how to provide security to a gendered individual are embedded in the ontological identity of an individual, which, as I will argue in the next section, has been made through personal-political imaginations of conflict and post-conflict.

\section{MAKING GENDER SECURITY POLICY}

Throughout this study, we have seen how gender security is a discourse that has been constructed and reproduced by feminist and women's activists in Scrbia. The preceding paragraphs pointed out that "gender security" is constitutive of ontological identity. This raises questions about how these ontological identities translate into the formation of a specific policy objective designed to achieve "gender security". I have argued in this thesis that a particular configuration of gender security has come into existence through personal-political imaginations of conflict and post-conflict. As discussed in chapter one, imaginations need not be about something that has happened: imaginations can also embody hope for the future. Chapter four looked at the claimed signification of "gender sccurity" held by activists. The chapter highlighted how the logics underpinning a signification of gender security was shaped by attitudes about Serbia's role in relation to the wars of the 1990s, perceptions about Scrbia's "post-conflict" present, and hopes for the future direction of "postconflict reconstruction". That is, this thesis places an emphasis upon temporality in the fixing of an identity: an identity which manifests itself in a particular configuration of "gender security" that becomes a policy objective. I will evaluate this argument further in the context of policy debates about how UNSCR 1325 can be implemented. Given that UNSCR 1325 is at the intersection of discourses about gender, and discourses about security, it can be said that activists "make" gender security policy in response to UNSCR 1325.

Briefly, it is worth restating the post-structural feminist debate about how a particular meaning of "gender security" is made in relation to UNSCR 1325. Laura Shepherd explores UN documents to investigate how accounts limit and make possible particular configurations of gender and security: 
where gender is equated with women and security necessarily is made by the international community. ${ }^{15}$ For Shepherd, these narratives function to "(re)produce a conventional, liberal "Westphalian" narrative of sovereignty', a dominant mode of thought re-establishing UNSCR 1325 as product/productive of conventional discourses of gender and security that rest upon (liberal) notions about international communities and individuals. ${ }^{16}$ While Christine Sylvester broadly agrees with Shepherd's problematisation of UNSCR 1325, she points out that,

'the UN is nothing if not a power-dealing set of organisations, whose official statements paper over or purposely hide difficult processes of issue definition and decision from the public eye. We need to be cautious when relying on written words for conclusions that could be overturned or tempered in unwritten politics' 17

Sylvester's call for a consideration of political processes and tensions in defining and making decisions about the configuration of "gender security" is important. The two case studies in this thesis suggest that, to some extent, both Shepherd and Sylvester are right. My findings in chapter six, where the Victimology Society reproduced an image of "gender security" present in the "violent reproduction' of the international, suggests that UNSCR 1325 issues a particular conceptualisation of "gender security" which actors reproduce. However, in chapter five, my findings suggest that activists can, and do, rebel against what is taken to be a dominant perception of "gender security", and have fought hard to ensure that their reconceptualised vision of "gender security" is heard. For activists involved in both debates, UNSCR 1325 and frameworks of "gender security" (however conceptualised) were important in opening up opportunities to achieve their objectives.

The realisation that UNSCR 1325 opens up opportunities for activists to pursue their political objectives is critical to understanding how gender security policy is made. UNSCR 1325, as mentioned in the introduction, was a document initially conceived to intervene in the functioning of the UN system operating in post-conflict contexts. And yet, NGO activists in Serbia have made use of the opportunities provided by the resolution in a variety of ways. Before evaluating the Serbian context, I first turn to an anecdote from Carol Cohn,

'I spoke' with a women from the Russian Committee of Soldiers' Mothers, for example, who told me that when they first got the resolution in the mail, they looked, thought, "Oh, just another Security Council tesolution," and didn't bother to read it. But later, someone looked and they've found it to be a gold mine. "Now," she says, "when we go to talk to political or military leaders, we take it with us. And because the Russian leadership is now very concerned

\footnotetext{
is Shepherd, Gender, Viakna and Secwrity.

16 Jbid. p. 397,400 . "Sylvester, 'Review of L. J. Shepherd Cender, Violence and Security: Discourse as Practice' Minernu' Jourmal of W'omen and W'ar Vol. 3, No. 1
(2009), pp. $94-96$.
} 
about their international legitimacy, they feel that they have to listen to us, because that's what the resolution says'"18

Cohn's anecdote demonstrates that with some consideration, UNSCR 1325 can be an effective political tool for feminist and women's organisations. A similar point was made in chapter five, where Women in Black begun to utilize UNSCR 1325 to support their political agency following a series of workshops on Women, Peace and Security, where they had space to consider what gender security might mean. That is, if activists have 'a room of one's own' to reflect upon, and learn about UNSCR 1325 and "gender security", they can see how the resolution opens up possibilities for their activism to be achieved: one way that gender security policy can be "made" is through a space for consideration.

Within that space for consideration, activists need to negotiate identities. One way that these identities are formed is through a perception of experience: hence why temporality so important in making a particular configuration of gender security. That is, as discussed in chapter four, to take steps towards gender security, it is necessary to interrogate our senses of in/security and gender. Christine Sylvester urges us, as sccurity studies scholars, to consider instances of insecurity as a 'sensory experience', and as 'an experience of the body'. ${ }^{19}$ To begin to do this, 'we might think about where security hurts or annoys us as individuals. We might think, that is, about what security feels like and does not feel like'.20 Chapter four exposed how stated significations of security are inscribed out of, and through senses of insecurity. Critical to understanding these perceptions of insecurity are interwoven personal - political imaginations of past, presents and futures: all temporal moments that constitute themselves in different forms to shape senses of insecurity and possible security. Memories that are recalled and lived experiences (re)present a past, a past that continues to affect the present, and where present problems are identified to highlight the direction of "progress" in the future. While poststructuralists have pointed out that "progress" is a problematic concept, it is critical to understand that the notion of "progress" plays a central part in the making of personalpolitical imaginations, shaping what is considered to be a way of achieving a "sense" of gender security.

Related to the notion of "progress", one question remains. Why do some articulations and representations of gender security come to the forefront, while others are excluded? In this thesis, an

1" Carol Cohn, speaking to Cynthia Enole When Feminists Look at Masculinity and the Men Who Wage War: A Conversation between Cynthia Enloe and Carol Cohn in C. Enloe The Curiows Fominist Seanthing for Women in a New Age of Empine (University of California Press, Berkeley, 2004), p. 262.

${ }^{19}$ Sylvester 'War, Sense, and Security", p. 24.

20 lbid, p. 26. 
analytical strategy concerned with how the temporality of conflict and post-conflict has been embedded within discourses of gender security has been utilised. This has demonstrated that certain political ideas are included or excluded because of hopes for the future, including perceptions about the future (successful) direction of post-war reconstruction, and how society can escape the postconflict problems. These visions and hopes for the future are limited or/and made possible through political-personal imaginations about the past and present. Critically, understanding these perceptions about the past and present (and subsequently, the future) are not about pointing out the flaws, stupidity, or weakness of an argument. Rather, understanding temporal perspectives sheds light upon how what we see is 'systematically related' to what we do not see. ${ }^{21}$ Through problematising how significations, articulations and representations of gender security are influenced by a range of temporal perspectives, this thesis has sought to illuminate the range of possibilities that are opened up for the future of gender and post-conflict.

In sum, a policy designed to achieve gender security (whatever gender security may look like), comes into existence through personal-political imaginations: an imagination that relies upon a host of temporalities. That is, to "make" policies aimed at achieving gender security, activists need a perception of what the past and present insecurities are (if any) to resolve these senses of insecurities in the future. In policy debates about how to implement UNSCR 1325, these temporal moments support the articulation and representation of a specific position. For Serbia, most of the temporal moments relate in some way to perceptions about conflict and post-conflict in the region.

\section{IDENTIFYING "POST-CONFLICT"}

Serbia's relationship to post-conflict has formed the basis of points of contention between different gender politics throughout this study. This serves to reinforce the long-held feminist awareness that wars do not just end: 'they fizzle and sputter' and continue to have gender effects long after peace treaties are signed and hostiles cease (if they ever really do). ${ }^{22}$ The Serbian feminist writer and commentator, Jasmina Tešanović, wrote on the day that Kosovo declared independence from Serbia on 17 February 2008 that,

'It been ten years now since I wrote my Diary of a Political Idiot, a book that started with riots in Kosovo. Although I've tried to stop writing that book, I have never been allowed to. ${ }^{23}$

\footnotetext{
21 J. J. Derrida, cited in M. Zchfuss Construttitism in Intermutional Relutions: The Politics of Reatioy (Cambridge University Prcss, Cambridge, 2002),
p. 204.

${ }^{22}$ C. Enloe The Moming After: Sexwal Politicr at the End of the Cold Wur (University of California Press, Berkeley, 1993), p. 2.

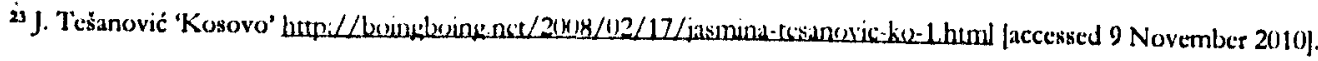


The Diary of a Political Idiot is a book that Jasmina wrote during the NATO bombings in Serbia in 1999, reflecting on everyday life in Belgrade. ${ }^{24}$ Her dairies discuss her feelings of guilt in relation to Serbia's role in conflicts of the 1990 s, and in particular the human wrongs committed in Kosovo;

'My friends and enemies from all over the world ask me, do you realise how terrible it is in Kosovo? I do, I really do, and I feel guilty that we feel bad here without having the horror they do... we [in Serbia] have a long way to run to catharsis, to be free from our bad conscience, wrong myths, inertia...25

That entry, written 6 April 1999, reveals the complexity of Jasmina's feelings about how Serbia relates to war and conflict. She feels that life is 'terrible' in Kosovo and that she should not feel that she is suffering as well, but acknowledges that 'we feel bad here' in Belgrade. Additionally, she points out that Serbia has 'a long way to run to catharsis': something that she has 'never been allowed to' stop writing about, even in 2008. That is, for some, Serbian state and society still needs to accept political responsibility for the crimes committed during the $1990 \mathrm{~s}$.

There are three connected points that I wish to draw out from Jasmina's words in order to draw together discussions about perceptions of "post-conflict" throughout this thesis. First, the way that Jasmina has problematised Serbia's relationship to "conflict" and "post-conflict". Second, the connections between post-conflict and the notion of political responsibility, and how they have been important in constituting gender politics in Serbia. Finally, and related to the political responsibility project, questions about the possibilitics of transcending "post-conflict" identities: can Jasmina ever stop writing The Diary of a Political Idiol?

While many have pointed out that wars do not simply "end" with the peace settlements, surprisingly few commentators have looked at the issues that might complicate the very notion of "post-conflict". A range of temporal and spatial assumptions govern the making and limitations of "post-conflict", potentially having significant gender effects. The debates about feminist-pacifism and domestic violence, discussed in chapters five and six, developed responses to post-conflict gender mainstreaming insistences of UNSCR 1325. That is, the configuration of "post-conflict" held by NGO activists, international institutions and Serbian society shaped how "gender security" discourse functioned in the context of these debates. Within the feminist-pacifist debate, discussed in chapter five, the post-conflict problem identified was the refusal of Serbian state and society to engage with political responsibility debates. In contrast, within the domestic violence debate, the post-conflict problem identified highlighted the ncgative consequences of war for women: war increased the

24 J. Teranovic 7te Dian of a Political ldiot: Nommal l je in a War Zone (Cleis Press, San Francisco, 2001).

${ }^{25} \mathrm{~J}$. Tesianovic 'La vitta e bella' Women in Black (eds.) Women's Side of W'ar (Women in Black, Bcigrade, 2008 ), p. 371. 
circulation of SALW, and combined with the violent social context of wartime, an increase in the use of SALW in domestic violence was detected. Thus, interpretations of "gender security" responded to the problematisations of conflict and post-conflict configured into existence.

Dubravka Zarkov and Cynthia Cockburn reminds us that 'when people speak of 'a society affected by war', we should not hear this as referring only to a country that has participated in the fighting, or on whose territory the war was fought'. ${ }^{26}$. While Serbia has perhaps more obvious recent connections to conflict and post-conflict than the Netherlands (which is where Zarkov and Cockburn are referring to), the problematisation of the spatial aspect of post-conflict is thought-provoking. These questions about how "post-conflict" is conceptualised resurfaced throughout my field research in Serbia. As noted in chapter four, activists held very different positions about Serbia's relationship to war and conflict. For example, very different attitudes towards the NATO bombings of Serbia in 1999 exist: for some, the bombings were like a war for $\mathrm{us}^{27}$, while for others, it is important to distinguish Serbia's problems during the 1990 s from the suffering experienced by those in Bosnia-I Ierzegovina. Even if a consensus about "conflict" could be reached, assessing if, and how Serbia is experiencing "post-conflict" problems is a different matter. Post-conflict can be configured in different ways, by different actors, and in response to different concerns. As this thesis is a single-country study, evaluations of the effects that a configuration of "post-conflict" can have upon gender policy is limited to comparisons between NGOs, state institutions and/or international actors in Serbia. However, these questions about the effects that a configuration of "post-conflict" has upon gender policy could be utilized in a comparative study of (for example) Serbia, Croatia, Bosnia-IIerzegovina and Kosovo.

As we have seen throughout this thesis, how "post-conflict" has been imagined has significant effects upon the formation of gender politics in Serbia. Chapter three, which was an overview of feminist and women's organising in Serbia, highlighted how perceptions about war and post-conflict played a major part in" defining the profile of an organisation. Most of these perceptions centre upon the importance of the political responsibility project to Serbia: for some activists, it is not a question that they wish to engage with or see as relevant to their activism, for others, the political responsibility project is critical to the achievement of gender equality in the future. The focus upon NGOs primarily concerned with gender - however interpreted - has centralised gender as an explanation for the various representation and knowledges of conflict and post-conflict in Serbia. This is at odds

26 D. Zarkov and C. Cockburn 'Introduction' Zarkov, D and Cockburn, C T\%e Postwur Moment: Militaries, Murculinities and Intemutional Pearkeeping (lawrence and Wishart, London, 2002), p. 9.

${ }^{27}$ Interview, Activist from Women's Centre Obrenovački, 16 April 2008. 
with many academic analyses concerned with conflict (in Serbia or elsewhere): many analyses render gender unimportant, but the constant presence of gender ensures 'gender ghosts' haunt the spectre of our understanding of conflict and post-conflict. ${ }^{28}$ The revelations in this thesis highlight how understandings of conflict and post-conflict are (re)made by gender politics, and vice versa, reinforcing the centrality and powerful force of gender structures, discourse, practice and assumptions in the very making of perceptions about conflict and post-conflict.

Highlighting the extent that "post-conflict" plays in the profiling of gender politics in Serbia ten fifteen years after the supposed end of conflicts in the Western Balkans throws up questions about the possibilities of transcending these post-conflict identities. Anna Lidström, the country coordinator for Kvinna Till Kvinna Serbia, a Swedish donor organisation working with women's organisations in conflict zones noted that one reason many groups are reluctant to work with UNSCR 1325 is because it is framed as a post-conflict resolution. ${ }^{29}$ She points out that activists often say "'I'm so, so tired of this conflict, I don't want to do that, I want to go forward"'.31 Elissa Helms, in her research on women's organisations in Bosnia-Herzegovina, found that activists hoped to push beyond the wartime identity of victimised Bosnian women. ${ }^{31}$ One activist told her that,

'sometimes all these stories really make me tired. Why can't I somehow live for the future and not constantly return to the past, even though I know it's necessary in this region. That's why I can't wait for them to finish all that in the Hague because then we can hopefully finish the past in our heads. ${ }^{32}$

It has been briefly touched upon throughout this thesis (in chapter four and six) that for some activists in Serbia, one possibility for transcending Serbia's post-conflict identity is through EU membership. Activists suggested that the willingness to subscribe to EU standards would be an indicator that Serbia has accepted the necessity of addressing questions about political responsibility, and/or has strengthened the effectiveness of government to deal with issues like domestic violence, and/or has accepted the independence of Kosovo. However, more is needed to give a greater insight into how activists seek to transcend post-conflict identities - or indeed, if they do at all. Asking questions about how a post-conflict zone is defined provokes related questions about how to transcend a post-conflict identity: a curiosity that could be usefully investigated through comparative post-conflict frameworks.

24 M. Zalewski 'Gender Ghosts in Meciarry and O'leary and Representations of the Conflict in Northern Ircland' Polisical Siudies, Vol. 53 (2005). pp. $201-221$.

${ }^{29}$ Interview, Anna lidistrom, the country coordinator for Kvinna Till Kvinna Serbia, Belgrade, 30 May 2008.

s) Ibid.

"Helms, E. 'Gendered Visions of the Bosnian Future: Women's Activism and Representation in Post-Was Bosnia-l lerzegovina' Phl Thesis, University of Pittsburgh, 2003; pp. 241 -2.

32 Ibid., p. 242. 


\section{RETHINKING GENDER POLITICS}

Central to this thesis has been the notion of personal-political imaginations. This framework has sought to bring together the critical feminist perception that the personal is political, and that we should be interested in everyday experiences, with the poststructural realisation that discourses are constituted. To do this, a text was made through a multi-sited approach that heavily utilised interviews. The challenge was to draw upon these personal stories and narratives without simply retelling them. I have sought to interpret the construction of activists narratives - not to criticise them or to render them "false" - but to reassert the importance of the "personal" in making the "political". These personal-political imaginations about conflict and post-conflict are constitutive of the framing of "gender politics" in Serbia. Through an approach concerned with the deconstruction of personal-political imaginations, this study has sought to present a way of thinking about the making of gender politics: not just within feminist and women's NGOs, but also within a wide range of political contexts, including international institutions, state and government departments, parliaments, universities, internet forums... Within this study, I argue that gender politics in Serbia is currently made possible and limited by personal-political imaginations of conflict and post-conflict.

In many respects, the selection of Scrbian feminist and women's NGOs as the focus of the study has highlighted how the framing of gender politics has been affected by (or even equated to) personalpolitical imaginations of conflict and post-conflict, but this need not be the case. For instance, a similarly framed study concerned with feminist and women's NGOs in South Africa would perhaps look at personal-political imaginations of apartheid. While it is certainly possible to investigate the effects of personal-political imaginations upon gender politics in a range of contexts, it is questionable if the approach could operate outside of a context which has not experienced a significantly traumatic and highly politicised event in recent memory, where a particular (set of) event(s) constitute a central point of return for reflection. It is those intensely politicised (and divisive) moments which impress themselves upon society and cause clearly identified ruptures in the making - and remaking - of gender politics. These questions do not detract from the powerful possibilities that making sense of personal-political imaginations has for the study of international politics. Personal-political imaginations, crucially, allow for analytical awareness of multiple temporalities: making perceptions about the past, present and future central to how international politics is understood. 
Over the course of research for this $\mathrm{PhD}$, I carried out three field trips to Serbia, and one to Kosovo.

(1) 27th February 2008 - 1st August 2008. Based in Belgrade, Serbia. As well as making daytrips from the capital, with some overnight stays, I also made short trips where I was based elsewhere.

(a) $19-22^{\text {nd }}$ May 2008, based in Subotica, Vojvodina.

(b) 26 - 29th May 2008, based in Novi Sad, Vojvodina.

(c) $1-13^{\text {th }}$ June 2008, based in Pristina, Kosovo.

(d) $30^{\text {th }}$ June $-3^{\text {rd }}$ July 2008 , based in Niš, South-east Serbia.

(e) $18^{\text {th }}-22^{\text {nd }}$ July 2008 , based in Novi Pazar, South-west Serbia.

This trip had four objectives in mind. First, to identify, through formal interviews and informal conversations, possible case studies to use in the thesis. This was the main focus between February and April 2008. Second, through interviews and participant observation, to gain a generalised picture of what "security" meant to activists within women and feminist organisations. This generated data which then became the basis of chapter four. Third, to gather a range of geographical and political positions within women and feminist organising in Serbia for an insight into the connections and tensions underpinning the profile of groups. Finally; to gather information about feminist pacifism and domestic violence in Scrbia through formal interviews (listed below), documents provided by the organisations I visited, and archival sources at the Centar za Zenske Studije i Istraqivanja Roda (Belgrade Women's Studies and Gender Rescarch Centre), located within the Politics Department, University of Belgrade.

(2) 31"m May - 19th June 2009. This trip was disrupted by emergency surgery on $12^{\text {th }}$ June, but up to then, I had been based in Belgrade, Serbia, and made day trips to Subotica and Novi Sad, and one longer visit to Leskovac, South-East Serbia.

(3) $12^{\text {th }}-19^{\text {th }}$ September 2009. Based in Belgrade, Serbia.

These trips primarily aimed to fill gaps in chapters five and six, ensuring the case studies covered included developments that took place in late 2008 and throughout 2009. Additionally, they enabled me to clarify areas of uncertainty, to seck additional confirmation for any controversial aspects, and to provide key informants with a progress report. 
96 individuals were interviewed across 79 separately recorded interviews. Ten people were interviewed twice, and one person (Lepa Mladjenović) was interviewed three times. All interviews, which lasted between 20 minutes and four hours, were semi-structured or unstructured. Participants were informed about the scope of the project at the start, with a clear indication that the key theme would be "security" in Serbia, but "security" was deliberately and explicitly left undefined by the researcher. While questions varied between participants depending upon (1) their position in relation to feminist and women's civil society, (2) the perspective that they were able to shed upon the issue area of concern to this thesis, certain commonalities remained throughout all interviews. All interviewees were asked what "security" meant to them, although only the data from activists was used in chapter four.

Consent to record and transcribe the interview was gained at the start of the recording. All participants were asked how they wished to be cited: for many activists concerned with political responsibility, it was an important element of their stance that they were cited by name and organisation, and as a consequence, they insisted upon this. While I have honoured their wishes in the vast majority of cases, there are aspects of the study where remarks have been cited as off the record either because I felt that it would cause unnecessary tension within organisations or that it would endanger the participant. Those who asked not be named have not been.

There were three interviews where participants did not wish to be recorded or cited. In accordance with their wishes, they do not appear in the list below, and have not been cited within the body of the text.

Please see the map of Serbia and Kosovo in the preface for an indication of the precise location of the town/city. Appendix (b) provides more information about each group.

Any interview not conducted entirely in English had translation support from a Serbian research assistant with a near-fluent command of English.

\begin{tabular}{|c|c|c|c|c|c|}
\hline Name(s) & Position(s) & Location & $\begin{array}{c}\text { Date } \\
\text { interviewed }\end{array}$ & Language(s) \\
\hline 1 & Bojan Alexsov & $\begin{array}{c}\text { Former Women in } \\
\text { Black activist. }\end{array}$ & London & $\begin{array}{c}28^{\text {th }} \text { January } \\
2008\end{array}$ & English \\
\hline 2 & $\begin{array}{c}\text { Diana } \\
\text { Miladnović }\end{array}$ & $\begin{array}{c}\text { Legal Advisor, } \\
\text { Autonomous } \\
\text { Women's Centre. }\end{array}$ & Belgrade & $11^{\text {th }}$ March 2008 & English \\
\hline 3 & $\begin{array}{c}\text { Vesna } \\
\text { Stanimirović }\end{array}$ & $\begin{array}{c}\text { Leader of Belgrade } \\
\text { Women's Forum } \\
\text { (Democratic Party). }\end{array}$ & Belgrade & $12^{\text {th } \text { March 2008 }}$ & Serbian \\
\hline 4 & Marija Perkovć & $\begin{array}{c}\text { Women in Black } \\
\text { activist (Vbras) }\end{array}$ & $\begin{array}{c}\text { Belgrade } \\
\text { (Vbras) }\end{array}$ & $21^{\text {st } \text { March 2008 }}$ & Serbian \\
\hline 5 & Miloš Urošević & $\begin{array}{c}\text { Women in Black } \\
\text { activist (Belgrade) }\end{array}$ & Belgrade & $21^{\text {st } \text { March 2008 }}$ & Serbian \\
\hline 7 & Katie Mauhorn & $\begin{array}{c}\text { Women in Black } \\
\text { activist (Belgrade) }\end{array}$ & Belgrade & $27^{\text {th } \text { March 2008 }}$ & English \\
\hline
\end{tabular}




\begin{tabular}{|c|c|c|c|c|c|}
\hline & Mladjenović & $\begin{array}{c}\text { Autonomous } \\
\text { Women's Centre. }\end{array}$ & & & \\
\hline 8 & Dragana Obrenić & $\begin{array}{l}\text { Leader of Zemun } \\
\text { Women's Forum } \\
\text { (Democratic Party) }\end{array}$ & Zemun & 29th March 2008 & English \\
\hline 9 & $\begin{array}{c}\text { Slavica } \\
\text { Stojanović }\end{array}$ & $\begin{array}{c}\text { Director of } \\
\text { Reconstruction } \\
\text { Women's Fund }\end{array}$ & Belgrade & 31st March 2008 & English \\
\hline 10 & $\begin{array}{c}\text { Adriana } \\
\text { Zaharijević }\end{array}$ & $\begin{array}{c}\text { Women in Black } \\
\text { activist - Belgrade }\end{array}$ & Belgrade & 10"h April 2008 & English \\
\hline 11 & Ciara Loughney & $\begin{array}{l}\text { SALW Awareness } \\
\text { Officer (UNDP) }\end{array}$ & Belgrade & $11^{\text {th }}$ April 2008 & English \\
\hline 12 & $\begin{array}{c}\text { Boban } \\
\text { Stojanović } \\
\end{array}$ & $\begin{array}{c}\text { Coordinator, } \\
\text { Queeria } \\
\end{array}$ & Belgrade & $11^{\text {th }}$ April 2008 & $\begin{array}{c}\text { Serbian and } \\
\text { English }\end{array}$ \\
\hline 13 & $\begin{array}{c}\text { Zorica } \\
\text { Trifunović } \\
\end{array}$ & $\begin{array}{c}\text { Women in Black } \\
\text { activist }\end{array}$ & Belgrade & 15th April 2008 & English \\
\hline 14 & 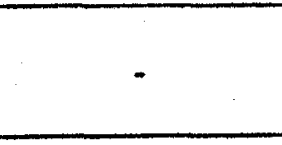 & $\begin{array}{c}\text { Women's Centre, } \\
\text { Obrenovac ( } 3 \\
\text { activists) }\end{array}$ & Obrenovac & 16th April 2008 & Serbian \\
\hline 15 & Ivana Radović & $\begin{array}{l}\text { ASTRA Anti Sex- } \\
\text { trafficking } \\
\text { Awareness officer }\end{array}$ & Belgrade & 17 th April 2008 & English \\
\hline 16 & $\cdot$ & $\begin{array}{l}\text { ASTRA Network } \\
\text { administrator }\end{array}$ & Belgrade & 17 th April 2008 & English \\
\hline 17 & $\begin{array}{l}\text { Jovanka Brkić } \\
\text { (Coordinator), } \\
\text { Sunićica Arsić } \\
\text { Marijanović and } \\
\text { Irina Ristić }\end{array}$ & $\begin{array}{l}\text { Women in Action } \\
\text { activists }\end{array}$ & Velika Plana & 17 th April 2008 & Serbian \\
\hline 18 & Nadja Duhačck & $\begin{array}{l}\text { Women in Black } \\
\text { activist - Belgrade }\end{array}$ & Belgrade & 22nd April 2008 & English \\
\hline 19 & Marina Iles & $\begin{array}{l}\text { Representative of } \\
\text { Provincial } \\
\text { Secretariat for } \\
\text { Gender Equality in } \\
\text { Vojvodina } \\
\end{array}$ & Novi Sad & 23rd April 2008 & English \\
\hline 20 & $\begin{array}{l}\text { Biljana Iličić } \\
\text { (coordinator), } \\
\text { Nevanda and } \\
\text { Vanda } \\
\end{array}$ & $\begin{array}{l}\text { Women's } \\
\text { Alternative } \\
\text { Workshop }\end{array}$ & Kikinda & $22^{\text {th }}$ April 2008 & $\begin{array}{l}\text { Serbian and } \\
\text { English }\end{array}$ \\
\hline 21 & Zorica Mrsević & $\begin{array}{c}\text { At time of } \\
\text { interview: Gender } \\
\text { Focal Point, OSCE } \\
\text { Serbia. Now } \\
\text { Deputy } \\
\text { Ombudsman, } \\
\text { Republic of Serbia. }\end{array}$ & Belgrade & 30"th April 2008 & English \\
\hline 22 & Ildiko Eredi & $\begin{array}{c}\text { Coordinator, } \\
\text { ZIMG, Pancevo }\end{array}$ & $\begin{array}{c}\text { Belgrade } \\
\text { (Pancevo) }\end{array}$ & $5^{\text {th }}$ May 2008 & English \\
\hline 23 & Jelena Višnjić & $\begin{array}{c}\text { Coordinator, Voice } \\
\text { of Difference }\end{array}$ & Belgrade & $10^{\text {th }}$ May 2008 & Serbian \\
\hline 24 & Marija Gaijcki & $\begin{array}{l}\text { Coordinator, } \\
\text { VIVISECT }\end{array}$ & Novi Sad & $13^{\text {th }}$ May 2008 & $\begin{array}{c}\text { Serbian and } \\
\text { English }\end{array}$ \\
\hline 25 & Nada Dabić & $\begin{array}{c}\text { Coordinator, } \\
\text { Espanaca }\end{array}$ & Novi Sad & $13^{\text {th }}$ May 2008 & Serbian \\
\hline 26 & - & Specialist advisor; & Belgrade & $15^{\text {th }}$ May 2008 & English \\
\hline
\end{tabular}




\begin{tabular}{|c|c|c|c|c|c|}
\hline & & $\begin{array}{l}\text { Confidence and } \\
\text { Security-building } \\
\text { Measures, OSEC } \\
\text { Serbia }\end{array}$ & & & \\
\hline 27 & $\begin{array}{c}\text { Jasmina } \\
\text { Knežević } \\
\text { (coordinator) } \\
\text { and six other } \\
\text { activists. }\end{array}$ & $\begin{array}{l}\text { Women's } \\
\text { Alternative }\end{array}$ & Sombor & $20^{\text {th }}$ May 2008 & Serbian \\
\hline 28 & $\begin{array}{c}\text { Mirjana } \\
\text { Dokmanović }\end{array}$ & $\begin{array}{c}\text { International } \\
\text { Gender Consultant }\end{array}$ & Subotica & $21^{\text {st May }} 2008$ & English \\
\hline 29 & $\begin{array}{c}\text { Radoslavia } \\
\text { Aralica and } \\
\text { Ljiljana Matić }\end{array}$ & $\begin{array}{c}\text { Zrenjanin } \\
\text { Education Centre }\end{array}$ & Zrenjanin & 27th May 2008 & English \\
\hline 30 & $\begin{array}{l}\text { Danica } \\
\text { Jovanović }\end{array}$ & $\begin{array}{c}\text { Za Bolje Sutra: } \\
\text { Roma Group Novi } \\
\text { Bečej. }\end{array}$ & $\begin{array}{c}\text { Belgrade } \\
\text { (Novi Bečej) }\end{array}$ & $28^{\text {th }}$ May 2008 & Serbian \\
\hline 31 & Svenka Savić & $\begin{array}{c}\text { Director, Women's } \\
\text { Studies }\end{array}$ & Novi Sad & 29:th May 2008 & English \\
\hline 32 & Biljana Stanković & $\begin{array}{c}\text { Coordinator, Novi } \\
\text { Sad Lesbian } \\
\text { Organisation }\end{array}$ & Novi Sad & $29^{\text {th }}$ May 2008 & English \\
\hline 33 & Anna Lidstrõm & $\begin{array}{c}\text { Kvinna Till } \\
\text { Kivinna, Serbia }\end{array}$ & Belgrade & $30^{\text {th }}$ May 2008 & English \\
\hline 34 & Igballe Rugova & $\begin{array}{c}\text { Coordinator, } \\
\text { Kosovo Women's } \\
\text { Network }\end{array}$ & Pristina & 3rd June 2008 & English \\
\hline 35 & $\begin{array}{c}\text { Mihane Nartile } \\
\text { Salihu-Bala }\end{array}$ & $\begin{array}{l}\text { Women in Black } \\
\text { activist - Pristina }\end{array}$ & Pristina & $3^{\text {rd J June } 2008}$ & English \\
\hline 36 & Valdete Idrizi & $\begin{array}{c}\text { Director; } \\
\text { Community } \\
\text { Building Mitrovica }\end{array}$ & $\begin{array}{l}\text { Pristina (K. } \\
\text { Mitrovica) }\end{array}$ & $4^{\text {th }}$ June 2008 & English \\
\hline 37 & Luljeta Vuniqi & $\begin{array}{l}\text { Executive Director; } \\
\text { Kosovar Gender } \\
\text { Studies Centre }\end{array}$ & Pristina & $5^{\text {th }}$ June 2008 & English \\
\hline 38 & Arjeta Rexhaj & $\begin{array}{c}\text { Executive Director; } \\
\text { Gender Studies and } \\
\text { Training Centre. }\end{array}$ & Pristina & $6^{\text {th }}$ June 2008 & English \\
\hline 39 & Malin Palm & $\begin{array}{c}\text { Kivinna Till } \\
\text { Kvinna, Kosovo }\end{array}$ & Pristina & $10^{\text {th }}$ June 2008 & English \\
\hline 40 & $\begin{array}{c}\text { UNIFEM } \\
\text { Pristina } \\
\text { Representative } \\
\text { (a) } \\
\end{array}$ & UNIFEM, Kosovo & Pristina & $10^{\text {th }}$ June 2008 & English \\
\hline 41 & $\begin{array}{c}\text { UNIFEM } \\
\text { Pristina } \\
\text { Representative } \\
\text { (b) }\end{array}$ & UNIFEM, Kosovo & Pristina & $10^{\text {th }}$ June 2008 & English \\
\hline 42 & Milica Simić & $\begin{array}{c}\text { Children's Roma } \\
\text { Centre } \\
\end{array}$ & Belgrade & $20^{\text {th }}$ June 2008 & Serbian \\
\hline 43 & Ciara Loughney & $\begin{array}{l}\text { SALW Awareness } \\
\text { Officer (UNDP) }\end{array}$ & Belgrade & $20^{\text {th }}$ June 2008 & English \\
\hline 44 & Lina Vušković & $\begin{array}{l}\text { Women in Black } \\
\text { activist - Belgrade }\end{array}$ & Belgrade & $25^{\text {th }}$ June 2008 & English \\
\hline 45 & $\begin{array}{c}\text { Slavica } \\
\text { Stonjanović }\end{array}$ & $\begin{array}{c}\text { Director of } \\
\text { Reconstruction }\end{array}$ & Belgrade & $27^{\text {th }}$ June 2008 & $\begin{array}{c}\text { English and } \\
\text { Serbian }\end{array}$ \\
\hline
\end{tabular}




\begin{tabular}{|c|c|c|c|c|c|}
\hline & & Women's Fund & & & \\
\hline 46 & Staśa Zajović & $\begin{array}{c}\text { Coordinator, } \\
\text { Women in Black - } \\
\text { Serbia }\end{array}$ & Belgrade & $29^{\text {th }}$ June 2008 & Serbian \\
\hline 47 & $\begin{array}{l}\text { Nevena Kostić, } \\
\text { Gordana } \\
\text { Stojiliković and } \\
\text { six other activists }\end{array}$ & Women For Peace & Leskovac & 1" July 2008 & Serbian \\
\hline 48 & Ana Sacipović & $\begin{array}{c}\text { Roma Women } \\
\text { "OSVIT" }\end{array}$ & Niš & $1^{\text {st }}$ July 2008 & Serbian \\
\hline 49 & $\begin{array}{l}\text { Svetlana Savić } \\
\text { and Jasmina } \\
\text { Mitrović }\end{array}$ & $\begin{array}{l}\text { SOS for Women } \\
\text { and Children }\end{array}$ & Vlasotince & $2^{\text {nd }}$ July 2008 & Serbian \\
\hline 50 & $\begin{array}{c}\text { Snezana } \\
\text { Jakovljević, } \\
\text { Mirjana } \\
\text { Jovanović and } \\
\text { Slavica } \\
\text { Stanojlović. }\end{array}$ & Sandglass & Kruševac & $3^{\text {td }}$ July 2008 & $\begin{array}{l}\text { English and } \\
\text { Serbian }\end{array}$ \\
\hline 51 & Miloš Urošević & $\begin{array}{l}\text { Women in Black } \\
\text { activist (Belgrade) }\end{array}$ & Belgrade & $4^{\text {th }}$ July 2008 & Serbian \\
\hline 52 & $\begin{array}{c}\text { Lilja } \\
\text { Radovanović }\end{array}$ & $\begin{array}{l}\text { Women in Black } \\
\text { activist (Belgrade) }\end{array}$ & Belgrade & $7^{\text {th }}$ July 2008 & Serbian \\
\hline 53 & $\begin{array}{l}\text { Slavoljupka } \\
\text { Parlović }\end{array}$ & $\begin{array}{l}\text { Legal Coordinator, } \\
\text { Autonomous } \\
\text { Women's Centre }\end{array}$ & Belgrade & $8^{\text {th }}$ July 2008 & $\begin{array}{l}\text { English and } \\
\text { Serbian }\end{array}$ \\
\hline 54 & Gizela Tot & $\begin{array}{c}\text { Women in Black } \\
\text { activist }\end{array}$ & Novi Sad & $9^{\text {th }}$ July 2008 & Serbian \\
\hline 55 & $\begin{array}{l}\text { Marija Gajicki, } \\
\text { and two other } \\
\text { activists. }\end{array}$ & VIVISECT & Novi Sad & $9^{\text {th }}$ July 2008 & $\begin{array}{l}\text { English and } \\
\text { Serbian. }\end{array}$ \\
\hline 56 & $\begin{array}{l}\text { Vesna Nikolic- } \\
\text { Ristanović }\end{array}$ & $\begin{array}{c}\text { Director, } \\
\text { Victimology Society } \\
\text { of Serbia. }\end{array}$ & Belgrade & $10^{\text {th }}$ July 2008 & English \\
\hline 57 & Aida Corović & $\begin{array}{c}\text { Coordinator, } \\
\text { Women's Forum } \\
\text { Sanžack }\end{array}$ & $\begin{array}{c}\text { Belgrade } \\
\text { Novi Pazar) }\end{array}$ & $\begin{array}{c}12^{\text {th }} \text { and } 15^{\text {th }} \text { July } \\
2008\end{array}$ & $\begin{array}{l}\text { Serbian and } \\
\text { English }\end{array}$ \\
\hline 58 & Sead Biberović & $\begin{array}{l}\text { Assistant Director, } \\
\text { URBAN-IN }\end{array}$ & Novi Pazar & 18th July 2008 & $\begin{array}{l}\text { Serbian and } \\
\text { English }\end{array}$ \\
\hline 59 & $\begin{array}{l}\text { Zibija Dh- } \\
\text { Śarenkapić }\end{array}$ & $\begin{array}{c}\text { Coordinator, } \\
\text { DAMAD }\end{array}$ & Novi Pazar & 19th July 2008 & Serbian \\
\hline 60 & - & $\begin{array}{c}\text { Novi Pazar Field } \\
\text { Office Manager, } \\
\text { USAID } \\
\end{array}$ & Novi Pazar & 21 st July 2008 & Serbian \\
\hline 61 & Mileva Malešić & $\begin{array}{c}\text { President, NGO } \\
\text { Women's Forum } \\
\text { Prijepolje }\end{array}$ & Prijepolje & 22nd July 2008 & Serbian \\
\hline 62 & $\begin{array}{c}\text { Lepa } \\
\text { Madjenović }\end{array}$ & $\begin{array}{c}\text { Coordinator, } \\
\text { Autonomous } \\
\text { Women's Centre. } \\
\end{array}$ & Belgrade & $25^{\text {th }}$ July 2008 & English \\
\hline 63 & Duśica Popadić & $\begin{array}{l}\text { Coordinator, Incest } \\
\text { Trama Centre }\end{array}$ & Belgrade & $28^{\text {th }}$ July 2008 & English \\
\hline 64 & $\begin{array}{l}\text { Alcksandar } \\
\text { Skundrić }\end{array}$ & Research Assistant & Belgrade & $28^{\text {th }}$ July 2008 & English \\
\hline 65 & $\begin{array}{c}\text { Gordana } \\
\text { Radaković }\end{array}$ & Research Assistant & Belgrade & 29 th July 2008 & English \\
\hline
\end{tabular}




\begin{tabular}{|c|c|c|c|c|c|}
\hline 66 & $\begin{array}{c}\text { Biljana } \\
\text { Kovaćević - } \\
\text { Vućo }\end{array}$ & $\begin{array}{c}\text { Director, } \\
\text { Committee of } \\
\text { Lawyers for Human } \\
\text { Rights }\end{array}$ & Belgrade & $30^{\text {th }}$ July 2008 & English \\
\hline 67 & $\begin{array}{c}\text { Mirjana } \\
\text { Dokmanović }\end{array}$ & $\begin{array}{c}\text { International } \\
\text { Gender Consultant }\end{array}$ & Subotica & 3rd June 2009 & English \\
\hline 68 & $\begin{array}{l}\text { UNDP Serbia } \\
\text { representatives } \\
\text { (a) and (b) }\end{array}$ & $\begin{array}{c}\text { Gender } \\
\text { Coordinators, } \\
\text { UNDP Serbia }\end{array}$ & Belgrade & $4^{\text {th }}$ June 2009 & English \\
\hline 69 & $\begin{array}{c}\text { Biljana } \\
\text { Kovaćević - } \\
\text { Vućo and Milan } \\
\text { Antonijević }\end{array}$ & $\begin{array}{l}\text { Director and } \\
\text { Executive director; } \\
\text { Committee of } \\
\text { Lawyers for Human } \\
\text { Rights. } \\
\end{array}$ & Belgrade & $8^{\text {th }}$ June 2009 & English \\
\hline 70 & Nataša Petrović & $\begin{array}{c}\text { Programme } \\
\text { Coordinator, } \\
\text { Belgrade Fund For } \\
\text { Political Excellence }\end{array}$ & Belgrade & $8^{\text {th }}$ June 2009 & English \\
\hline 71 & Zorica Mrševic & $\begin{array}{c}\text { Deputy } \\
\text { Ombudsman, } \\
\text { Republic of Serbia }\end{array}$ & Belgrade & 9th June 2009 & English \\
\hline 72 & $\begin{array}{c}\text { Lepa } \\
\text { Mladjenović }\end{array}$ & $\begin{array}{c}\text { Coordinator, } \\
\text { Autonomous } \\
\text { Women's Centre. }\end{array}$ & Belgrade & $12^{\text {th }}$ June 2009 & English \\
\hline 73 & Svenka Savić & $\begin{array}{l}\text { Director, Women's } \\
\text { Studies }\end{array}$ & Novi Sad & $12^{\text {th }}$ June 2009 & English \\
\hline 74 & $\begin{array}{l}\text { UNIFEM Serbia } \\
\text { representative }\end{array}$ & $\begin{array}{l}\text { Gender Advisor, } \\
\text { UNIFEM Serbia. }\end{array}$ & Belgrade & $\begin{array}{c}15^{\text {th }} \text { September } \\
2009\end{array}$ & English \\
\hline 75 & Anna Lidström & $\begin{array}{c}\text { Kvinna Till Kvinna, } \\
\text { Serbia and } \\
\text { Montenegro }\end{array}$ & Belgrade & $\begin{array}{c}1^{\text {th }} \text { September } \\
2009\end{array}$ & English \\
\hline 76 & Sonja Stojanović & $\begin{array}{c}\text { Director, Centre for } \\
\text { Civil-Military } \\
\text { Relations }\end{array}$ & Belgrade & $\begin{array}{c}\text { 17th September } \\
2009\end{array}$ & English \\
\hline 77 & Jasmina Nikolić & $\begin{array}{l}\text { Victimology Society } \\
\text { of Serbia. }\end{array}$ & Belgrade & $\begin{array}{c}1^{1 \text { th }} \text { September } \\
2009\end{array}$ & English \\
\hline 78 & $\begin{array}{c}\text { Ivan } \\
\text { Zveržhanovski }\end{array}$ & $\begin{array}{l}\text { SALW Project } \\
\text { Officer, South- } \\
\text { Eastern Europe } \\
\text { Small Arms } \\
\text { Clearinghouse } \\
\text { (SEESAC) }\end{array}$ & Belgrade & $\begin{array}{c}18^{\text {th }} \text { September } \\
2009\end{array}$ & English \\
\hline 79 & Staśa Zajović & $\begin{array}{c}\text { Coordinator, } \\
\text { Women in Black - } \\
\text { Serbia }\end{array}$ & Belgrade & $\begin{array}{c}18^{\text {th }} \text { September } \\
2009\end{array}$ & $\begin{array}{l}\text { English and } \\
\text { Serbian }\end{array}$ \\
\hline
\end{tabular}


Detailed notes were made after each observation (the exceptions being observations 6 and 8 , where notes were made during the observation). Photographs were taken where possible. Notes concentrated upon describing the event and deconstruction of the symbolism and discursive logies of the actions. Observations 1, 4 and 7 provided me with an opportunity to seek out and approach possible intervicwees.

1. 8th March 2008. International Women's Day: Book Launch for Neko je Rekao Feminzam (Someone said Feminism). Belgrade.

2. 14th March 2008. Informal gathering in Women in Black - Belgrade office to prepare materials for the Peace March planned for $15^{\text {th }}$ March.

3. 15th March 2008. (rescheduled) International Women's Day Peace March. Performance on Trg Republic followed by a one hour march through central Belgrade.

4. 4'h June 2008. Kosovo Women's Network film screening Women, The Forgotten Face of War. Film screening and reception, ODA Theatre, Pristina.

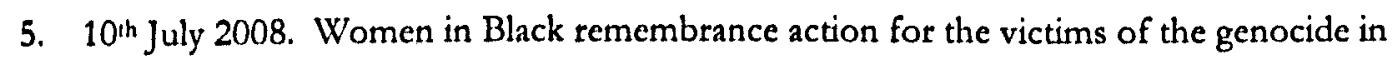
Srebrenica. Trg Republic, Belgrade.

6. $11^{\text {th }}$ July 2008. Women in Black vigil to Srebrenica, Bosnia - Herzegovina.

7. 18th July 2008. Press conference to launch Sandazk Women's Forum. Novi Pazar, SouthWest Serbia. Press conference and reception.

8. 5- $7^{\mathrm{h}} \mathrm{h}$ June 2009 . Women in Black network action and meeting on antimilitarisation, Kukaviča, Leskovac. 


\section{APPENDIX (B): NGO INTERESTS AND RELATIONSHIPS}

This is designed as a reference point for all the organisations based in Serbia that are mentioned in this thesis. The table does not exclusively consist of women's and feminist organisations, and nor does it aim to be a comprehensive overview of all women's and feminist organisations in Serbia. Based upon qualitative interview data, websites and pamphlets produced by the group, aims to outline the gender interests and stances taken towards war and political responsibility of the civil society organisations mentioned in this thesis.

Key for Networks and Partnerships:

1. WiB: This group is formally part of the Women in Black - Serbia network. This does not include instances where activists within a group that is not connected to Women in Black self-identify as Women in Black activists. An explicit connection with Women in Black suggests that activists would describe themselves as feminist-pacifists.

2. AŽC: This group is involved in the Autonomous Women's Centre network. The AŽC provides training and support for the functioning of SOS Hotlines to counsel those suffering domestic violence.

3. FC: This refers to groups involved in the Feminist Coalition, made up of groups in Belgrade. The Feminist Coalition shares a critical attitude towards the state and its policies regarding political responsibility and the status of Kosovo. The Feminist Coalition have collaborated on documents analysing the success of CEDAW in Serbia and have produced many joint press releases criticising state policies that they feel endanger women's human rights.

4. KTK: This group has funding from Kvinna Till Kvinna, a Swedish donor organisation supporting feminist and women's organisations concerned with long-term peace-building and post-conflict reconstruction. The data here is based upon Kvinna Till Kvinna's annual reports 2006, 2007, and 2008. A connection with Kvinna Till Kvinna would suggest that the organisation refers to postconflict in funding applications, given that Kvinna Till Kvinna's primary work is in supporting women's organising in conflict and post-conflict regions. 


\begin{tabular}{|c|c|c|c|c|c|c|c|}
\hline \multirow{2}{*}{ 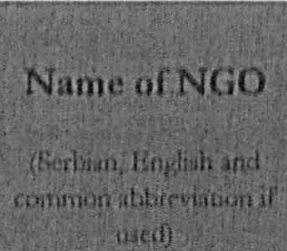 } & \multirow[b]{2}{*}{ location } & \multirow{2}{*}{$\begin{array}{l}\text { Gender } \\
\text { petspective. }\end{array}$} & \multirow{2}{*}{$\begin{array}{l}\text { Attitudes towards } \\
\text { war and political } \\
\text { responsibility. }\end{array}$} & \multicolumn{4}{|c|}{$\begin{array}{l}\text { Networks and } \\
\text { Partnerships }\end{array}$} \\
\hline & & & & WiB & $A Z C$ & $\mathrm{FC}$ & KTK \\
\hline $\begin{array}{l}\text { ASTRA Anti Trafficking } \\
\text { Action }\end{array}$ & Belgrade & $\begin{array}{l}\text { Feminist principles } \\
\text { but not across all } \\
\text { employees. }\end{array}$ & $\begin{array}{l}\text { Individual activists link } \\
\text { war-related violence and } \\
\text { nationalism to } \\
\text { contemporary sex- } \\
\text { trafficking issues in Serbia, } \\
\text { but not all. }\end{array}$ & & & - & \\
\hline $\begin{array}{l}\text { Autonomni tenski centre. } \\
\text { Autonomous Women's } \\
\text { Centre (AZ̈C) }\end{array}$ & Belgrade & $\begin{array}{l}\text { Not a feminist } \\
\text { organisation, but } \\
\text { many employees and } \\
\text { activists are self- } \\
\text { declared feminists. }\end{array}$ & $\begin{array}{l}\text { Individual activists are } \\
\text { critical of war-related } \\
\text { politics, and many link the } \\
\text { violence of the } 1990 \text { s to } \\
\text { particular types of } \\
\text { domestic violence. These } \\
\text { are individual decisions, } \\
\text { not an organisational } \\
\text { perspective. }\end{array}$ & & - & & \\
\hline $\begin{array}{l}\text { Beogradski fond za polititkes } \\
\text { izwetnosh. Belgrade Fund } \\
\text { for Political Excellence } \\
\text { (BFPE) }\end{array}$ & Belgrade & $\begin{array}{l}\text { Some employees have } \\
\text { a gender interest. }\end{array}$ & $\begin{array}{l}\text { See Euro-Atlantic } \\
\text { integration as a critical } \\
\text { clement of Serbia's } \\
\text { progression. Implicit } \\
\text { assumption to accepting } \\
\text { political responsibility is } \\
\text { critical for this. }\end{array}$ & & & & \\
\hline $\begin{array}{l}\text { Kultumi Centar D } A M A D \text { : } \\
\text { Cultural Centrc } \\
\text { D } \triangle M A D\end{array}$ & Novi Pazar & Feminist. & $\begin{array}{l}\text { Not stated during } \\
\text { interview. }\end{array}$ & & • & & \\
\hline $\begin{array}{l}\text { Deciji Romski Centar: } \\
\text { Children's Roma Centre. }\end{array}$ & Belgrade & $\begin{array}{l}\text { Feminist but } \\
\text { distinguishes between } \\
\text { "white" and "black" } \\
\text { (i.c. Roma) feminism. }\end{array}$ & $\begin{array}{l}\text { Not stated during } \\
\text { intervicw. }\end{array}$ & & - & & \\
\hline Espanaca & Novi Sad & Feminist-pacifist. & $\begin{array}{l}\text { Explicit about need for } \\
\text { political responsibility. }\end{array}$ & • & & & \\
\hline $\begin{array}{l}\text { Glas Ravilike Voicc/Vote } \\
\text { of Difference: 'Glas' has } \\
\text { a dual meaning in } \\
\text { Serbian - it means to } \\
\text { report, to vote, or to } \\
\text { voice. }\end{array}$ & Belgrade & Ficminist. & $\begin{array}{l}\text { Explicit about need for } \\
\text { political responsibility. }\end{array}$ & & & • & \\
\hline $\begin{array}{l}\text { Incest T'rauma Centre } \\
\text { (ITC) }\end{array}$ & Belgrade & Explicitly feminist. & $\begin{array}{l}\text { Explicit about need for } \\
\text { political responsibility. }\end{array}$ & & & $\bullet$ & \\
\hline NGOWomen's Forum & Prijepolje & $\begin{array}{l}\text { Women's } \\
\text { organisation. }\end{array}$ & $\begin{array}{l}\text { Not stated during } \\
\text { interview. }\end{array}$ & & & & \\
\hline $\begin{array}{l}\text { Novi Sad Lesbian } \\
\text { Organisation (NLO) }\end{array}$ & NoviSad & $\begin{array}{l}\text { Feminist Lesbian } \\
\text { organisation }\end{array}$ & $\begin{array}{l}\text { Explicit about need for } \\
\text { political responsibility. }\end{array}$ & & & & - \\
\hline $\begin{array}{l}\text { Udrušenje zena pestamik } \\
\text { Sandglass Women's } \\
\text { Organisation. }\end{array}$ & Kruševac & Feminist & $\begin{array}{l}\text { Explicit about need for } \\
\text { political responsibility. }\end{array}$ & • & • & & $\bullet$ \\
\hline
\end{tabular}




\begin{tabular}{|c|c|c|c|c|c|c|c|}
\hline Quecria & Intemet presence & $\begin{array}{l}\text { Gay rights } \\
\text { organisation. Some } \\
\text { members are feminist }\end{array}$ & $\begin{array}{l}\text { Explicit about need for } \\
\text { political responsibility. }\end{array}$ & $\bullet$ & & & \\
\hline $\begin{array}{l}\text { Rekonstrukcija Zenksi } \\
\text { Fond. Rcconstruction } \\
\text { Women's Fund (R'Zli) }\end{array}$ & Belgrade & Feminist. & $\begin{array}{l}\text { lixplicit about need for } \\
\text { political responsibility, but } \\
\text { this is not a guiding } \\
\text { principle of how funds ate } \\
\text { distributed. }\end{array}$ & & & - & \\
\hline $\begin{array}{l}\text { Udruženjc Romkinja } \\
\text { "OSVIT" (Association } \\
\text { of Rumany Women } \\
\text { "OSVIT") }\end{array}$ & $\mathrm{Nis}$ & $\begin{array}{l}\text { Women's organisation } \\
\text { with some feminist } \\
\text { principles. }\end{array}$ & $\begin{array}{l}\text { Nor stated during } \\
\text { interview. }\end{array}$ & & & & \\
\hline $\begin{array}{l}\text { SOS qu ine } i \text { deck: SOS } \\
\text { Women and Children }\end{array}$ & Vlasotince & Explicitly feminist. & $\begin{array}{l}\text { Lixplicit about need for } \\
\text { political responsibility. }\end{array}$ & • & $\bullet$ & & \\
\hline URBAN-IN & Novi Pazar & $\begin{array}{l}\text { Key activists have } \\
\text { gender concerns. }\end{array}$ & $\begin{array}{l}\text { Explicit about nced for } \\
\text { political responsibility. } \\
\text { Social aspect of post- } \\
\text { conflict transition is a } \\
\text { critical clement of their } \\
\text { work }\end{array}$ & & & & \\
\hline $\begin{array}{l}\text { L'ikimuliko druithe Srbije: } \\
\text { Victimology Sucicty of } \\
\text { Serbia }\end{array}$ & Bclgrade, Subotica & $\begin{array}{l}\text { (jender concem, } \\
\text { feminist heritage. }\end{array}$ & $\begin{array}{l}\text { Strongly support the } \\
\text { notion of political } \\
\text { rciponsibility. }\end{array}$ & & & & \\
\hline $\begin{array}{l}\text { Tojiodenka regimalna } \\
\text { tenska iniciojatiou } \\
\text { Vojvodina Regional } \\
\text { Women's Initiative }\end{array}$ & Novi Sad. & $\begin{array}{l}\text { Iluman rights } \\
\text { organisation with } \\
\text { many feminist } \\
\text { activists - fominist } \\
\text { heritage. }\end{array}$ & $\begin{array}{l}\text { Explicit about need for } \\
\text { political responsibility. } \\
\text { Social aspect of post- } \\
\text { confict transition is a } \\
\text { critical element of their } \\
\text { work. }\end{array}$ & & & & \\
\hline $\begin{array}{l}\text { Za bulje sulru: wdruqinjo } \\
\text { roma Noti Beifj: For } \\
\text { Tomorrow's Colour: } \\
\text { Roma Association Novi } \\
\text { Bečej }\end{array}$ & Novi Bečcj & leminist. & $\begin{array}{l}\text { Not statcd during } \\
\text { intervicw. }\end{array}$ & & & & \\
\hline $\begin{array}{l}\text { Zenska aliematite: } \\
\text { Women's Altemative }\end{array}$ & Sombor & $\begin{array}{l}\text { Rcluctant to associate } \\
\text { themselves with } \\
\text { politicised fominism. }\end{array}$ & $\begin{array}{l}\text { Did not view political } \\
\text { responsibility as a relevant } \\
\text { concern for their activities. }\end{array}$ & & & & • \\
\hline $\begin{array}{l}\text { Zenku altemudite rasimica: } \\
\text { Women's Altemative } \\
\text { Workshop. }\end{array}$ & Kikinda & Ficminist. & $\begin{array}{l}\text { Ixplicit about need for } \\
\text { political responsibility. }\end{array}$ & & & & \\
\hline $\begin{array}{l}\text { Zene wakiyji: Women in } \\
\text { Action. }\end{array}$ & Velika I'lana & $\begin{array}{l}\text { Women's organisation } \\
\text { with fominist activists. }\end{array}$ & $\begin{array}{l}\text { Kuy individuals are explicit } \\
\text { about the need for political } \\
\text { responsibility, but political } \\
\text { responsibility activitics are } \\
\text { not central to the } \\
\text { organisation's work. }\end{array}$ & & & . & \\
\hline $\begin{array}{l}\text { Zene \& mumr. Women in } \\
\text { Black }\end{array}$ & $\begin{array}{l}\text { Belgrade (and other } \\
\text { locations) }\end{array}$ & $\begin{array}{l}\text { Very explicitly } \\
\text { feminist - pacifist. }\end{array}$ & $\begin{array}{l}\text { Extremely explicit about } \\
\text { need for political } \\
\text { responsibility. }\end{array}$ & $\bullet$ & & $\bullet$ & 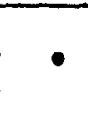 \\
\hline Women's Centre & Obrenovac & $\begin{array}{l}\text { Rejects the fominist } \\
\text { label. }\end{array}$ & $\begin{array}{l}\text { Did not vicw political } \\
\text { responsibility as a rclevant } \\
\text { concern for their activities. }\end{array}$ & & & & \\
\hline
\end{tabular}




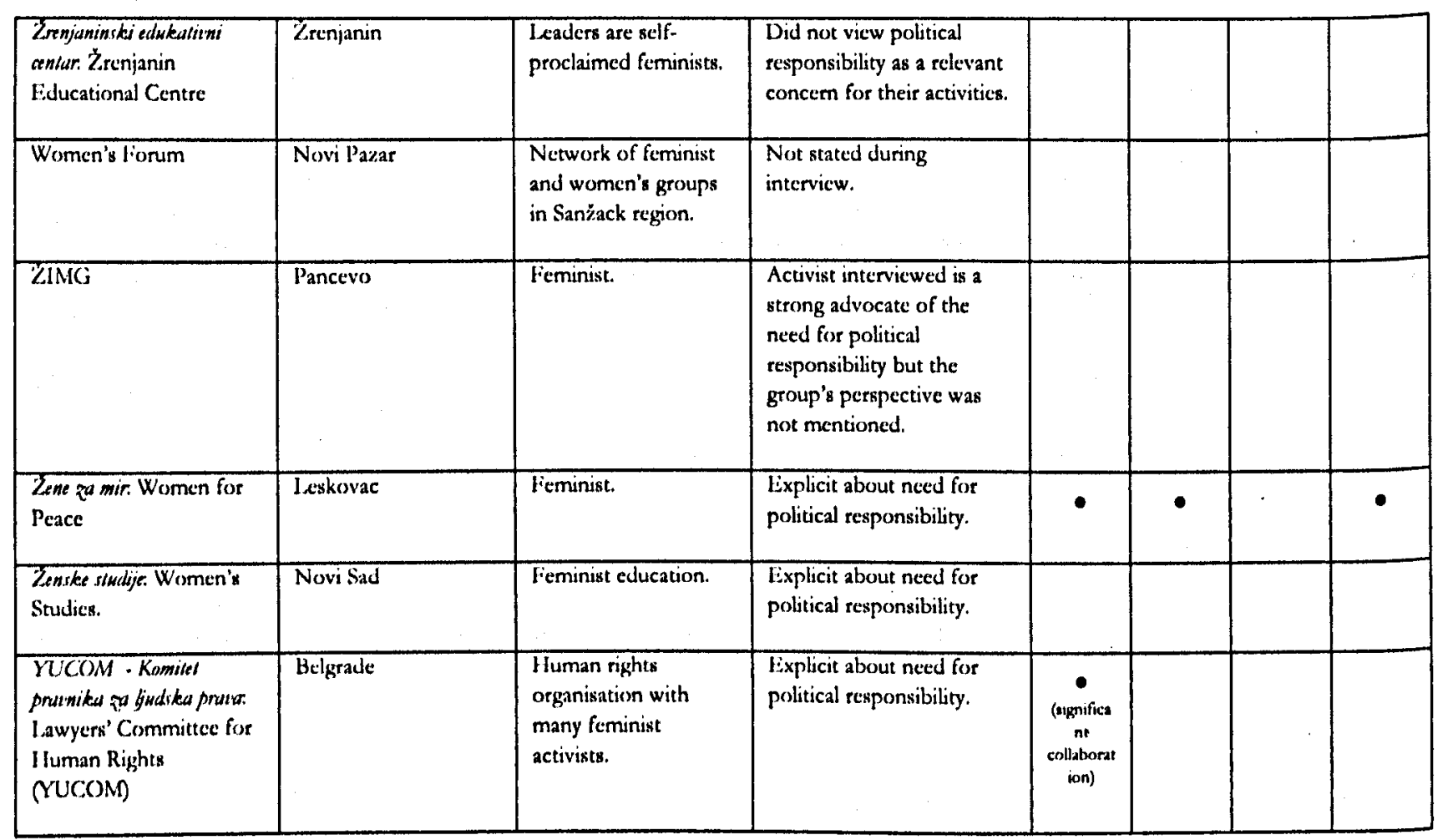


Retrieved from hrrp://www.un.org/events/res 1325c.pdf [accessed 22 July 2010].

\section{United Nations S/RES/1325 (2000)}

\section{Adopted by the Security Council at its 4213th meeting, on 31 October 2000}

\section{The Security Council,}

Recalling its resolutions 1261 (1999) of 25 August 1999, 1265 (1999) of 17 September 1999, 1296 (2000) of 19 April 2000 and 1314 (2000) of 11 August 2000, as well as relevant statements of its President, and recalling also the statement of its President to the press on the occasion of the United Nations Day for Women's Rights and International Peace (International Women's Day) of 8 March 2000 $(\mathrm{SC} / 6816)$,

Recalling also the commitments of the Beijing Declaration and Platform for Action (A/52/231) as well as those contained in the outcome document of the twenty-third Special Session of the United Nations General Assembly entitled "Women 2000: Gender Equality, Development and Peace for the Twenty-First Century" (A/S-23/10/Rev.1), in particular those concerning women and armed conflict,

Bearing in mind the purposes and principles of the Charter of the United Nations and the primary responsibility of the Security Council under the Charter for the maintenance of international peace and security,

Expressing concern that civilians, particularly women and children, account for the vast majority of those adversely affected by armed conflict, including as refugees and internally displaced persons, and increasingly are targeted by combatants and armed elements, and recognining the consequent impact this has on durable peace and reconciliation,

Reaffirming the important role of women in the prevention and resolution of conflicts and in peacebuilding, and stressing the importance of their equal participation and full involvement in all efforts for the maintenance and promotion of peace and security, and the need to increase their role in decisionmaking with regard to conflict prevention and resolution,

Reafirming also the need to implement fully international humanitarian and human rights law that protects the rights of women and girls during and after conflicts,

Emphasizing the need for all parties to ensure that mine clearance and mine awareness programmes take into account the special needs of women and girls,

Recognizing the urgent need to mainstream a gender perspective into peacekeeping operations, and in this regard noting the Windhoek Declaration and the Namibia Plan of Action on Mainstreaming a Gender Perspective in Multidimensional Peace Support Operations (S/2000/693),

Recognizing also the importance of the recommendation contained in the statement of its President to the press of 8 March 2000 for specialized training for all peacekeeping personnel on the protection, special needs and human rights of women and children in conflict situations,

Recognizing that an understanding of the impact of armed conflict on women and girls, effective institutional arrangements to guarantee their protection and full participation in the peace process can significantly contribute to the maintenance and promotion of international peace and security, 
Noting the need to consolidate data on the impact of armed conflict on women and girls,

1. Urges Mcmber States to ensure increased representation of women at all decision-making levels in national, regional and international institutions and mechanisms for the prevention, management, and resolution of conflict;

2. Encourages the Secretary-General to implement his strategic plan of action (A/49/587) calling for an increase in the participation of women at decisionmaking levels in conflict resolution and peace processes;

3. Urges the Secretary-General to appoint more women as special representatives and envoys to pursue good offices on his behalf, and in this regard calls on Member States to provide candidates to the Secretary-General, for inclusion in a regularly updated centralized roster;

4. Further urges the Secretary-General to seek to expand the role and contribution of women in United Nations ficld-based operations, and especially among military observers, civilian police, human rights and humanitarian personnel;

5. Expresses its willingness to incorporate a gender perspective into peacekeeping operations, and urges the Secretary-General to ensure that, where appropriate, field operations include a gender component;

6. Requests the Secretary-General to provide to Member States training guidelines and materials on the protection, rights and the particular needs of women, as well as on the importance of involving women in all peacekeeping and peacebuilding measures, invites Member States to incorporate these elements as well as HIV/AIDS awareness training into their national training programmes for military and civilian police personnel in preparation for deployment, and further requests the SecretaryGeneral to ensure that civilian personnel of peacekeeping operations receive similar training;

7. Urges Member States to increase their voluntary financial, technical and logistical support for gender sensitive training efforts, including those undertaken by relevant funds and programmes, inter alia, the United Nations Fund for Women and United Nations Children's Fund, and by the Office of the United Nations I ligh Commissioner for Refugees and other relevant bodies;

8. Calls on all actors involved, when negotiating and implementing peace agreements, to adopt a gender perspective, including, inter alia:

(a) The special needs of women and girls during repatriation and resettlement and for rehabilitation, reintegration and post-conflict reconstruction;

(b) Measures that support local women's peace initiatives and indigenous processes for conflict resolution, and that involve women in all of the implementation mechanisms of the peace agreements;

(c) Measures that ensure the protection of and respect for human rights of women and girls, particularly as they relate to the constitution, the electoral system, the police and the judiciary;

9. Calls upon all parties to armed conflict to respect fully international law applicable to the rights and protection of women and girls, especially as civilians, in particular the obligations applicable to them under the Geneva Conventions of 1949 and the Additional Protocols thereto of 1977, the Refugee Convention of 1951 and the Protocol thereto of 1967, the Convention on the Elimination of All Forms of Discrimination against Women of 1979 and the Optional Protocol thereto of 1999 and the United Nations Convention on the Rights of the Child of 1989 and the two Optional Protocols thereto of 25 May 2000, and to bear in mind the relevant provisions of the Rome Statute of the International Criminal Court;

10. Calls on all parties to armed conflict to take special measures to protect women and girls from gender-based violence, particularly rape and other forms of sexual abuse, and all other forms of violence in situations of armed conflict; 
11. Emphasizes the responsibility of all States to put an end to impunity and to prosecute those responsible for genocide, crimes against humanity, and war crimes including those relating to sexual and other violence against women and girls, and in this regard stresses the need to exclude these crimes, where feasible from amnesty provisions;

12. Calls upon all parties to armed conflict to respect the civilian and humanitarian character of refugee camps and settlements, and to take into account the particular needs of women and girls, including in their design, and recalls its resolutions 1208 (1998) of 19 November 1998 and 1296 (2000) of 19 April 2000;

13. Encourages all those involved in the planning for disarmament, demobilization and reintegration to consider the different needs of female and male ex-combatants and to take into account the needs of their dependants;

14. Reaffirms its readiness, whenever measures are adopted under Article 41 of the Charter of the United Nations, to give consideration to their potential impact on the civilian population, bearing in mind the special needs of women and girls, in order to consider appropriate humanitarian exemptions;

15. Expresses its willingness to ensure that Security Council missions take into account gender considerations and the rights of women, including through consultation with local and international women's groups;

16. Invites the Secretary-General to carry out a study on the impact of armed conflict on women and girls, the role of women in peace-building and the gender dimensions of peace processes and conflict resolution, and further invites him to submit a report to the Security Council on the results of this study and to make this available to all Member States of the United Nations;

17. Requests the Secretary-General, where appropriate, to include in his reporting to the Security Council progress on gender mainstreaming throughout peacekeeping missions and all other aspects relating to women and girls;

18. Decides to remain actively seized of the matter. 
Website addreasen: The intemet country Code top-level domain for Serbia started to change from .yu to .rs in March 2008, with yu being retired in September 2009: many organisations took the opportunity to create new websites, removing much of the historical information used in this thesis.

Acsady, J. 'Urges and Obstacles: Chances for Feminism in Eastern Europe' in W'omen's Studies International Forum, Vol. 22, No, 4 (1999), pp. $405-409$.

Ackerly, B. A., Stern, M. and True, J. Feminist Methodologies for Intermational Relations (Cambridge University Press, Cambridge, 2006).

AdvocacyNet News Bulletin 132 'Serbian Government Bans Peace March Commemorating International Women's Day Amidst Kosovo Backlash' 10 March 2008.

Agh, A. The Politics of Central Europe (Sage, London, 1998).

Al-Ali, N and Pratt, N. What Kind of Liberation? Women and the Occupation of Irag (University of California Press, Berkley, 2010).

Allen, B. Rape Warfare: The Hidden Genocide in Bosnia-Herzegovina and Croatia (University of Minnesota Press, Minneapolis, 1996).

Allison, F. II. 'Remembering a Vietnam War Firefight: Changing Perspectives over Time' in Oral History Review, Vol. 31, No. 2 (2004), pp. $69-83$.

Alvarez, S. E. Engendering Democracy in Brazil: Women's Movements in Transition Politics (Princeton University Press, Princeton, 1990).

Anderlini, S. N. 'Peace Negotiations and Agreements' in Hunt Alternatives Fund and International Alert Inclusive Security, Sustainable Peace: A Toolkit for Advocacy and Action (London, 2004).

Argent, A. 'Hatching Feminisms: Czech Feminist Aspirations in the 1990s' Gender and History, Vol. 20, No. 1. (2008), pp. $86-104$. 
Ashley, R. 'The Achievements of Post-Structuralism' in International Theory: Positivism and Beyond S. Smith, K. Booth and M. Zalewski (eds.) (Cambridge University Press, Cambridge, 1996), pp. 240 53.

Autonomous Women's Centre, Belgrade 'Spreading Promising Practices: Autonomous Women's Centre Annual report 2007' rretrieved from hitp://www.womenngo.rs [accessed 10 July 2009].

Autonomous Women's Centre, Belgrade 'Collaborate to Bring Change: Autonomous Women's Centre Annual report 2005' retrieved from htrp://www.womenngo.rs [accessed 8 July 2009].

Autonomous Women's Centre, Belgrade 'Let's coordinate the Action: Autonomous Women's Centre biannual report 2003/2004' retrieved from http://www.womennyo.rs [accessed 8 July 2009].

Autonomous Women's Centre, Belgrade 'To Participate Actively and Together: Annual Report of the Autonomous Women's Centre, Belgrade 2002' retrieved from hitp://www,womenngo.rs [accessed 8 July 2009].

Autonomous Women's Centre, Belgrade 'Getting Stronger Opposing Violence: Annual Report of the Autonomous Women's Centre, Belgrade 2001' retrieved from hitp://www.womenngo.rs [accessed 8 July 2009].

Autonomous Women's Center 'Mission and Goals' htpp://www.womenngo.org.ju [accessed 16 June 2006 and no longer available].

B92 'MPs adopt Srebrerica deckration' 31 March 2010 whw.b92ner [accessed 31 March 2010].

B92 'Opinion poll on Srebrenica resolution' 3 February 2010 wuw. b92.net [accessed 05 March 2010].

B92, 'EU lifts visa restrictions for Scrbia' 30 November 2009 http://www.b22.net/eng/news/politicsarticlc.php? $\mathrm{mm}=11 \& \mathrm{dd}=30 \mathrm{~g} y \mathrm{y}=2002$ [accessed 8 February 2010].

B92 Tadic bemoans "unbroken thread of violence" October 12009 retrieved bttp://uww.b22.net/eng/news/politics [accessed 1 October 2009].

B92 'Predlog Deklaracije o Srebrenici' (Proposal for a Declaration on Srebrenica) 11 July 2009 retrieved from http://www.b)2 net/info on 1 August 2009. 
Babuna, A. 'The Albanians of Kosovo and Macedonia: Ethnic Identity Superseding Religion' Nationalities Papers, Vol. 28, No. 1 (2000), pp. 67 - 92.

Baden, S. and Goetz, A. M. Who Needs [Sex] When You Can Have [Gender]? Conflicting Discourses on Gender at Beijing' in Feminist Review Vol. 56 (1997), pp. 3 - 25.

Bagić, A. 'Women's Organising in Post-Yugoslav Countries: Talking about 'Donors" in J. Gould and H. S. Marcussen (eds.) Ethnographies of Aid: Exploring Development Texts and Encounters, Occasional Paper Series, International Development Studies at Roskilde University, (2004), pp. $199-226$.

Bagic, A. International Assistance for Women's Organising in South Eastern Europe: From Groups and Initiatives to NGOs Report: CPS International Policy Fellowship Program 2001/2002 (Central European University Center for Policy Studies, Budapest, 2002).

Barrow, A. '[It's] like a rubber band.' Assessing UNSCR 1325 as a gender mainstreaming process' International Joumal of Law in Context, Vol. 5, No. 1, (2009) pp. 51 - 68.

Basu, S. 'Security Through Transformations: The Case of the Passage of UN Security Council Resolution 1325 on Women, Peace and Security' PhD Thesis, Aberystwyth University, 2009.

Beckwith, K. Beyond Compare? Women's Movements in Comparative Perspective' in European Joumal of Political Research Vol. 37, No. 4 (2000), pp. 431 - 469.

Belgrade Fund for Political Excellence United Nations Security Council Resolution 1325 in Serbia - On Women, Peace and Security (Belgrade Fund for Political Excellence, April 2010).

Belgrade Fund For Political Excellence (Conference Programme) 'Implementation of UNSCR 1325 in Serbia' Kovacica, Serbia, 22 - 24 May 2009 (In author's possession)

Bellamy, A. J. (ed.) International Society and its Critics (Oxford University Press, Oxford, 2005).

Bhaskar, R. 'On the Ontological Status of Ideas' Journal for the Theory of Social Behaviour, Vol. 27, No. 23 (1997), pp. $139-147$.

Bialasiewicz, L. Campbell, D. Elden, S. et al. Performing Security: The Imaginative Geographies of current US Strategy' Political Geograpby Vol. 26 (2007), pp. 405 - 22. 
Bilbija, V. and Simić, B. Reinnik Englesko-Srpski, Srpsko-Engleski (Star Publications, New Dehli, 2003).

Blagojević, M. Knowledge Production at the Semiperiphery: A Gender Perspective (SZR "Zuhra Simić", Belgrade, 2009).

Blagojević, M. 'Belgrade's Protests 1996/1997: From Women in the Movement to Women's Movement?' in J. Lukić, J. Regulska and S. Zaviršek (eds.) Women and Citizenship in Central and Eastern Europe (Aldershot, 2006) pp. $147-64$.

Blagojević, M. (ed.) Ka Vidlivoj Ženskoj Istoriji: Ženski pokeret u Beogradu 90-ih (Towards a Women's History: The Women's Movement in Belgrade in the 1990s) (Centar Za Ženske Studije, Beograde, 1998).

Blanchard, E. M. 'Gender, International Relations, and the Development of Feminist Security Theory' in Signs: Journal of Women in Culture and Society Vol. 28, No. 4 (2003), pp. 1289- 1312.

Bleiker, R. Popular Dissent, Human Agency and Global Politics (Cambridge University Press, Cambridge, 2000).

Bond, J. and Phillips, R. Violence Against Women as a Iuman Rights Violation: International Institutional Responses' in Sourcebook on Violence Against W'omen (eds.) Claire M. Renzetti, J. L. Edleson and R. K. Bergen (Sage Publications, Thousand Oaks, London, 2001), pp. 481 - 499.

Booth, K. Theory of World Security (Cambridge University Press, Cambridge, 2007).

Booth, K. 'I Iuman Wrongs and International Relations' Intermational Affuirs, Vol. 71, No. 1 (1995), pp. $103-126$.

Booth, K. Security and Self: Reffections of a Fallen Realist YVISS Occasional Paper 26 (Toronto, October 1994).

Booth, K. 'Security and Emancipation' Revies of Intermational Studies Vol. 17 (1991), pp. 313 - 326.

Bonfiglioli, C. Belgrade 1978: Remembering the Conference Drug-ca zena. Zensko pitanje - novi pristop thirty years after' Unpublished dissertation, Utrecht University (August 2008). 
Bourne, M., Godwick, W., Green, $\mathrm{O}$ (et. Al.) Reviewing Action on Small Arms: Assessing the First Five Years of the UN Programme of Action by Biting the Bullet (IANSA, 2006) retrieved from lattp://iansa.org/un/revicw2006/tredloook2006/ [accessed 19 January 2010].

Bozic, V. 'The Post TV News Syndrome' in Peace Magazine 'War Rape: Letters from ex-Yugoslavia' retrieved from hetp://archive.peacemigazine org/v09112p24.htm [accessed 29 July 2009].

Bracewell, W. 'Rape in Kosovo: Masculinity and Serbian Nationalism' Nations and Nationalism, Vol. 6, No. 4 (2003), pp. $563-90$.

Bracewell, W. Women, Motherhood and Contemporary Serbian Nationalism' Women's Studies International Forum, Vol. 19, No. 1 -2 (1996), pp. 25 - 33.

Brankovic, B and Lukić, A. Alternative Report to the CEDAW Committee (Belgrade, 2007).

Bryson, V. 'Time-Use Studies: A Potentially Feminist Tool' International Feminist Joumal of Politics, Vol. 10, No. 2 (2008), pp. $135-153$.

Buckley, M. 'Women in the Soviet Union' Feminist Review No. 8, (1981), pp.79 - 106.

Bull, H. 'Society and Anarchy in International Relations' (1960) in Der Derian, J., (ed.) International Theory: Critical Investigations (Macmillan, Basingstoke, 1995) pp. 75 - 93.

Bunch, C. 'A Feminist Iluman Rights Lens on Human Security' speech given at the National Council for Research on Women Annual Conference, May 2003. Centre for Women's Global Leadership, Rutgers, The State University of New Jersey. Retrieved from him://cougl.nitgers.cdu [accessed 28 August 2009].

Bunch, C. Women's Rights as Human Rights: Toward a Revision of Human Rights' Human Rights Quarterly Vol. 12 (1990), pp. $486-98$.

Burchill, S., et. al. (eds.) Theories of International Relations (Palgrave, Basingstoke, 1995).

Burgress, J. P. and Owen, T. (eds.) 'Special Section: What is Human Security?' Security Dialogue, Vol. 35, No. 3 (2004), pp. $345-87$.

Burgess, R. G. (ed.) Field Researib: a Sourcebook and Field Manual (Unwin Hyman, London, 1982). 
Burgess, R. G. 'Personal Documents, Oral Sources and Life Histories' R. G. Burgess (ed.) Field Research: a Sourcebook and Field Manual (Unwin Hyman, London, 1982), pp. 200 - 8.

Butler, J. Gender Trouble (Routledge, London, 2007).

Butler, J. Excitable Speech: A Politics of the Perfomative (Routledge, London, 1997).

Butler, J. Bodies that Matter. In the Discursive Limits of "Sex" (Routledge, London, 1993).

Buzan, B. Rethinking Security After the Cold War' Cooperation and Conflict Vol. 32, No. 1 (1997), pp. 5 -28 .

Buzan, B. 'The timeless wisdom of realism?' in S. Smith, K. Booth and M. Zalewski (eds.) International Theory: Positivism and Beyond (Cambridge University Press, Cambridge, 1990) pp. 47- 65.

Buzan, B. People, States and Fear. An Agenda for Security Studies in the Post-Cold War Fra (Lynne Rienner, London, 1991).

Buzan, B., and IJansen, L. The Evolution of International Security Siudies (Cambridge University Press, Cambridge, 2009).

Buzan, B., Waver, O. and de Wilde, J. Security: A New Framework for Analysis (Lynne Rienner, London, 1998).

c.a.s.e Collective 'Critical Approaches to Security In Europe: A Networked Manifesto' Security Dialogue Vol. 37, No. 4 (2006), pp. $443-487$.

Campbell, D. 'Poststructuralism' in T. Dunne, M. Kurki and S. Smith (eds.) International Relations Theories: Discipline and Diversity (Oxford University Press, Oxford, 2007), pp. 201 - 228.

Campbell, D. National Deconstrution: Violence, Identity, and Justice in Bosnia (University of Minnesota Press, Minneapolis, 1998). 
Campbell, D. Writing Security: United States Foreign Policy and the Politics of Identity (Manchester University Press, Manchester, 1992).

Caprioli, M. 'Feminist IR Theory and Quantitative Methodology: A Critical Analysis' International Studies Review, Vol. 6 (2004), pp. 253 - 69.

Carey, H. F. 'Women and Peace and Security': the Politics of Implementing Gender Sensitivity Norms in Peacekeeping' International Peacekeeping Vol. 8, No. 2 (2007), pp. 49 - 68.

Carpenter, R. C. 'Gender Theory in World Politics: Contributions of a Nonfeminist Standpoint?' International Studies Review, Vol. 4 (2002), pp. 153- 165.

Carver, T. (ed.) 'Forum: Gender and International Relations' International Studies Review, Vol 5, No. 2 (2003), pp. $287-302$.

Carver, T. Gender Is Not a Synonym for Women (London, Lynne Rienner, 1996).

Cerwonka, A. Travelling Feminist Thought: Difference and Transculturation in Central and Eastern European Feminism' Signs: Journal of Women in Culture and Society, Vol. 35, No. 4 (2008), pp. 809 - 832.

Chandler, D. 'Review Essay. Human Security: The Dog That didn't Bark' Security Dialogue Vol. 39, No. 4 (2008), pp. $427-438$.

Cockburn, C. and Zarkov, D. The Postwar Moment: Militaries, Masculinities and International Peacekeeping (Lawrence and Wishart, London, 2002).

Cockburn, C. 'Gender Relations as Casual in Militarisation and War' International Feminist Journal of Politics Vol. 12, No. 2, pp. $139-157$.

Cockburn, C. From Where we Stand: War, Women's Activism and Feminist Analysis (Zed Books, London, 2007).

Cockburn, C. The Space Between Us: Negotiating Gender and National Identities in Conflict (Zed Books, London, 1998). 
Cockburn, C. 'A Women's Political Party for Yugoslavia: Introduction to the Serbian Feminist Manifesto’ Feminist Review No. 39 (1991), pp. 155 - 160.

Cohn, C. 'Feminist Peacemaking: In Resolution 1325, The United Nations Requires the Inclusion of Women in All Peace Planning and Negotiation' The Women's Review of Books, Vol. 21, No. 5 (2004), pp. 8-9.

Cohn, C. 'Mainstreaming Gender in UN Security Policy: A Path to Political Transformation?' in S. M. Rai and G. Waylen (eds.) Global Govermance: Feminist Perspectives (Palgrave, London, 2008), pp. 185 206.

Cohn, C. 'Motives and Methods: using multi-sited ethnography to study US national security discourses' in B. A. Ackerly, M. Stern and J. True (eds.) Feminist Methodologies for International Relations (Cambridge University Press, Cambridge, 2006), pp. 91 - 107.

Cohn, C. et al 'Workshop on Strategies for Grassroots Implementation of Resolution 1325' Paper presented to The Boston Consortium on Gender, Security and Human Rights on November 42004 , retrieved from http://www.genderandsccurity.org/mecting.heml[accessed 10 February 2008].

Cohn, C., Kinsella, H. and Gibbings, S. 'Women, Peace and Security: Resolution 1325' International Feminist Journal of Politics, Vol. 6, No. 1, (2004) pp. $130-140$.

Collin, M. This is Serbia Calling: Rock 'n' Roll Radio and Belgrade's Underground Resistunce (Serpent's Tail, London, 2004).

Connell, R. W. 'Change among the Gatekeepers: Men, Masculinities, and Gender Equality in the Global Arena' Signs: Journal of Women in Culture and Society Vol. 30, No. 3, (2005) pp. $1801-1825$.

Conway, D. 'Masculinities and Narrating the Past: Experiences of Researching White Men who Refused to Serve in the Apartheid Army' Qualitative Research, Vol. 8, (2008), pp. 347 - 54.

Corrin, C. 'Post-Conflict Reconstruction and Gender Analysis in Kosova' International Feminist Journal of Politics, Vol. 3, No. 1 (2001), pp. 78 - 98.

Corrin, C. (ed.) Women in a Violent World (Edinburgh University Press, Edinburgh, 1996). 
Cox, R.W. 'Social Forces, States and World Orders: Beyond International Relations Theory' Millennium: Journal of International Studies, Vol. 10, No. 2, pp. 126-155.

Copić S. Wife Abuse in the Countries of Former Yugoslavia' Feminist Review No. 76, (2004) pp. 46 64.

Davis, N. Eumpe: $A$ History (Pimlico, London, 1997).

D' Costa, B. 'Marginalised Identity: New Frontiers of Research for IR' in B. A. Ackerly, M. Stern and J. True (eds.) Feminist Methodologies for International Relations (Cambridge University Press, Cambridge, 2006), pp. $129-52$.

de Saussure, F. Course in General Linguistics (eds.) C. Bally and A. Sechehaye (Foutana/Collins, Glasgow, 1960).

de Volo, L. B. and Schatz, E. 'From the Inside Out: Ethnographic Methods in Political Research' PS: Political Science and Politics, Vol. 37, No. 2 (2004), pp. 267 - 71.

Der Derian, J. 'The Boundarics of Knowledge and Power in International Relations' J. Der Derian and M. J. Shapiro International/Intertextual Relations: Postmodern Readings of World Politics (Lexington Books, New York, 1989), pp. 3- 10.

Der Derian, J. and Shapiro, M. J. (eds.) International/Intertextual Relations: Postmodern Readings of World Politics (Lexington Books, New York, 1989).

Derrida, J. Of Grammatology (Trans.) G. C. Spivak (John Hopkins University Press, Baltimore, 1997).

Desai, M. 'From Vienna to Beijing: Women's Human Rights Activism and the Human Rights Community' in P. V. Ness (ed.) Debating Human Rights: Critical essays from the United States and Asia (Routledge, London, 1999), pp. $184-96$.

Devetak, R. 'Postmodernism' S. Burchill et. al. (eds.) Theories of International Relations (Palgrave, Basingstoke, 1996), pp. $181-208$. 
Dillon, M. Politics of Security: Towards a Political Philosopby of Continental Thought (Routledge, London, 1996).

Drakulić, S. Café Europa: Life After Communism (Abacus, London, 1996).

Drakulić, S. How We Survived Communism and Even Laughed (Vintage, London, 1992).

Dokmanovic, M. Firearms Possession and Domestic Violence in the Western Balkans: A Comparative Siudy of Legislation and Implementation Mechanisms (SEESAC, Belgrade, 2007).

Doty, R. L. 'States of Exception on the Mexico-U.S. Border: Security, "Decisions," and Civilian Boarder Controls' International Political Sociology Vol. 1, No. 2 (2007), pp. 113 - 137.

Doyle, M. 'Kant, Liberal Legacies, and Foreign Affairs: Part 1' Philosopby and Public Affuirs 12, 3 (1983), pp. 205 - 235. Part 2 is published in Philosophy and Public Affuirs Vol. 12, No. 4 (1983), pp. 325 - 53.

Duelli-Klein, $R$. 'How to do what we want to do: thoughts about feminist methodology' $R$. DuelliKlein and G. Bowles (eds.) Theories of Women's Siudies (Routledge, London, 1983), pp. 88 - 104.

Dufficld, M. Global Governance and the New Wars: The Merging of Development and Security (Zed Books, London, 2001).

Duhaček, D. Belgrade Women's Studies Centre - Next Stage?' http://www.\%enskestudic.edu.yu/pages/ncxtstagc.htm [accessed 3 August 2007. No longer available. The Centre for Women's Studies is now at htp://zenskestudic.edu.rs / [accessed 3 June 2010]]

Duhaček, D. 'The Making of Political Responsibility: Jannah Arendt and/in the case of Scrbia' J. Lukić, J. Regulska and D. Zaviršek Women and Cilizenship in Central and Eastern Europe (Ashgate, Hampshire, 2006) pp. $205-221$.

Duhaček, D. 'Belgrade Women's Studies Centre' in The European Journal of W'omen's Studies, Vol. 5, (1998) pp. $489-97$.

Dunne, T., Kurki, M. and Smith, S. International Relations Theories: Discipline and Diversity (Oxford University Press, Oxford, 2007). 
Dunne, T. and Wheeler, N. J. "We the Peoples": Contending Discourses of Security in Human Rights Theory and Practice' International Relations, Vol. 18, No. 1 (2004), pp. 9 - 23.

Dunne, T. and Wheeler, N. J. (eds.) Human Rights in Global Politics (Cambridge, Cambridge University Press, 1999).

Edkins, J. Trauma and the Memory of Politics (Cambridge University Press, Cambridge, 2003).

Edkins, J. 'After the Subject of International Security' in A. Finlayson and J. Valentine (eds.) Politics and Post-Structuralism: An Introduction (Edinburgh University Press, Edinburgh, 2002) pp. 66-80.

Einhorn, B. Citizenship in an Enlarging Europe: From Dream to Awakening (Palgrave, London, 2006).

Einhorn, B. Cinderella Goes To Market: Citizenship, Gender and Women's Movements in East Central Eumpe (Verso, London, 1993).

Einhorn, B. and Sever, C. 'Gender and Civil Socicty in Central and Eastern Europe' International Feminist Journal of Politics, Vol. 5, No. 2 (2003), pp. $163-190$.

Elshtain, J. B. W'omen and W'ar (University of Chicago Press, Chicago, 1995).

Emerson, R. M., Fretz, R. I., and Shaw, L. L. Writing Ethnographical Fieldnotes (University of Chicago Press, Chicago, 1995).

Enloe, C. Globalization and Militarism: Feminists Make the Link (Rowman and Littlefield, Lanham, 2007).

Enloe, C. The Curious Feminist: Searthing for Women in a New Age of Empire (University of California Press, Berkeley, 2004).

Enloe, C. Bananas, Beaches and Bases: Making Feminist Sense of International Politics (University of California Press, Berkeley, 2000).

Enloe, C. The Morning After. Sexual Politics at the End of the Cold War (University of California Press, Berkeley, 1993). 
Enloe, C. 'Feminists Thinking About War, Militarism, and Peace' Bess, B. B. and Marx-Ferree, M. (eds.) Anabring Gender, A Handbook of Social Sizence Reseurib (Newbury Park, Sage Publications, 1987) pp. 526-47.

Farr, V. 'The Impacts on Women of Prolific Small Arms and Light Weapons' Canadian Women's Studies, Vol. 22, No. 2 (2003), pp. $56-63$.

Farr, V. and K. Gebre-Wold (eds.) Brief 24 Gender Perspectives on Small Arms and Light Weapons: Regional and International Concerns (Bonn International Centre for Conversion, Bonn, 2002).

Farmsworth, N. Through W'omen's Solidarity to a Just Peace: $A$ Report based on the Women's Peace Coalition Second Annual Conference (Pristina, 2007).

Freedman, L. 'Victims and Victors: Reflections on the Kosovo War' Revien of International Studies, Vol. 26 (2000), pp. 335 - 358.

Fridman, O. 'Alternative Voices in Public Urban Spaces: Serbia's Women in Black' Ethnologia Balkanica, Vol. 10 (2006) pp. 291 - 303.

Feffer, J. Shockwaves: Eastern Europe After The Revolutions (Black Rose Books, Montréal, 1992).

Finlayson, A. and J. Valentine (eds.) Politics and Post-structuralism: An Introduction (Edinburgh University Press, Edinburgh, 2001).

Finlayson, A and Valentine, J. 'Introduction' in A. Finlayson and J. Valentine (eds.) Politics and Poststructuralism: An Introduction (Edinburgh University Press, Edinburgh, 2001) pp. 1 -20.

Florea Hudson, N. Gender, Human Security and the United Nations: Security Language as a Political Framework for Women (Routledge, London, 2009).

Foucault, M. The Archaeology of Knowledge (Routledge, London, 2008).

Funk, N. and Müller, M (eds.) Gender Politics and Post-Communism: Reflections from Eastern Europe and the Former Soviet Union (Routledge, London, 1993) 
Funk, N. 'Introduction' in N. Funk and M. Mueller (eds) Gender Politics and Post-communism: Reflections from Eastern Europe and the Former Soviet Union (Routledge, London, 1993), pp. 1 - 14.

Funk, N. and Müller, M. et al 'Dossier on Women in Eastern Europe', in Social Text, No. 27 (1990), pp. $88-102$.

Gal, S. and Kligman, S. (eds.) Reproducing Gender. Politics, Publics, and Everyday Life after Socialism (Princeton University Press, Princeton: New Jersey, 2000).

Ghodsee, K. Nongovernmental Ogres? How Feminist NGOs Undermine Women in Postsocialist Eastern Europe' in The International Journal of Not-for-Profit Law, Vol. 8, No. 3 (2006). Online Journal. www.icnl.org/knowledge/iinl [accessed 27 November 2010].

Giles, W., de Alwis, M., Klcin, E. and Silva, N. (eds.) Feminists Under Fire: Exchanges Across War Zones (Between the Lines, Toronto, 2003).

Glenny, M. The Balkans 1804 -1999: Nationalism, War and The Great Powers (Granta Books, London, 2000).

Glynos, J. and Howarth, D. Logics of Critical Explanation in Social and Political Theory (Routledge, London, 2007).

Grandchamp, F. AP Fellowship Blog hutp://www,advocacjnet.org [accessed 28 August 2009].

Grodcland, A. B. 'Suspiciously supportive or suspiciously obstructive? - The Relationship Between Local Government and NGOs in Bosnia \& Hetzegovina, Serbia and Macedonia', International Joumal of Public Administration, Vol. 31, No. 8 (2008) pp. 911-52.

Grǿdcland, A. B. Public Perceptions of Non-Governmental Organisations in Serbia, Bosnia \& Herzegovina and Macedonia' Communist and Post-Communist Studies, Vol. 39, No. 2 (2006), pp. 221-46.

Hall, S. (ed.) Representation: Cultural Representations and Signifying Practices (Sage, London, 2003).

Hall, S. 'The Work of Representation' S. Hall (ed.) Representation: Cultural Representations and Signifying Practices (Sage, London, 2003), pp. 13 - 74. 
Handrahan, L. 'Conflict, Gender, Ethnicity and Post-Conflict Reconstruction' Security Dialogue Vol. 35, No. 4 (2004), pp. $429-445$.

Hansen, L. 'Ontology, Epistemologies and Methodologies' in L. J. Shepherd Gender Matters in Global Politics: A Feminist Introduction to International Relations (Routledge, London, 2010)

Hansen, L. 'From Camps to Conversations in Critical Security Studies' Intermational Studies Review, Vol. 10, No. 3 (2008), pp. $652-4$.

Hansen, L. Security As Practice: Discourse Analysis and the Bosnian War (Routledge, Abingdon, 2006).

Hansen, L. and Olsson, L. 'Guest Editors Introduction' Security Dialogue, 35, 4 (2004), pp. 405-9.

Hansen, L. 'Gender, Nation, Rape: Bosnia and the Construction of Security' International Feminist Journal of Politics Vol. 3, No. 1 (2001), pp. 55 - 75.

Hansen, L. 'The Little Mermaid's Silent Security Dilemma and the Absence of Gender in the Copenhagen School' in Millennium: Joumal of International Studies Vol. 29, No. 2 (2000) pp. 289 - 306.

Hanke, S. H. 'The World's Greatest Unreported Hyperinflation' initially published in Globe Asia, May 2007. Retrieved from CATO Institute http://www.cato.org/pub display.php?pul] id =8232 [accessed 9 March 2010].

Harding, S. 'Introduction: Is there a feminist method?' in S. Harding (ed.) Feminism and Methodology (Indiana University Press, Bloomington and Indianapolis, 1987), pp. $1-14$.

Helms, E. 'Gender Essentialisms and Women's Activism in Post-War Bosnia-I Ierzegovina' in W. Giles, M. de Alwis, E. Klein and N. Silva (eds.) Feminists Under Fire: Exchanges across War Zones (Between the Lines, Toronto, 2003), pp. $181-198$.

Helms, E. Women as Agents of Ethnic Reconciliation? Women's NGOs and International Intervention in Bosnia-I Ierzegovina' Women's Studies International Forum, Vol. 26, No. 1 (2003), pp. 15 -33 .

Helms, E. 'Gendered Visions of the Bosnian Future: Women's Activism and Representation in PostWar Bosnia-Herzegovina' PhD Thesis, University of Pittsburgh, 2003. 
Hemment, J. Empowering Women in Russia: Activism, Aid, and NGOs (Indiana University Press, Bloomington, 2007).

Henderson, S. L. Building Democracy in Contemporary Russia: Western Support for Grassroots Organisations (Cornell University Press, London, 2003).

Henderson, S. L. 'Selling civil society: Western aid and the Nongovernmental Organization Sector in Russia' in Comparative Political Studies, Vol. 35, No. 2 (2002), pp. 139 - 67.

Herz, J. 'Idcalist Internationalism and the Security Dilemma' World Politics, Vol. 2, No. 2 (1950), pp. $157-80$.

Hesse-Biber, S. N. 'Feminist Research: Exploring the Interconnections of Epistemology, Methodology and Method' S. N. Hesse-Biber (ed.) The Handbook of Feminist Research (Sage Publications, London, 2007), pp. 1 - 28.

Ifess, B. and Marx-Ferree, M. Analyzing Gender: A Handbook of Social Science Research (SAGE, Newbury Park, 1987).

Heyzer, N. 'Gender, Peace and Disarmament' Disarmament Forum No. 4 (2003), pp. 5 - 16.

Higate, P. and IIenry, M. Insecure Spaces: Peacekeeping, Power and Performance in Haiti, Kosovo and Liberia (Zed Books, London, 2009).

Hill, F. 'How and When has Security Council Resolution 1325 (2000) on Women, Peace and Security Impacted Negotiations Outside the Security Council' Unpublished Master Thesis, Uppsala University Programme of International Studies, 2004-2005.

Hill, F., Aboitiz, M. and Poehlem-Doumbouya, S. Nongovernmental Organizations' Role in the Buildup and Implementation of Security Council Resolution 1325' in Signs: Journal of W'omen in Culture and Society, Vol. 28, No. 4 (2003), pp. 1255 - 1269.

Hobbes, T. (ed. R. Tuck) Leviathan (Cambridge University Press, Cambridge, 1996). 
Hobden, S. and Hobson, J. M. (eds.) Historical Sociology of International Relations (Cambridge University Press, Cambridge, 2002).

Hobson, J. M. 'What's at stake in 'bringing historical sociology back into international relations'? Transcending 'chronofetishism' and 'tempocentrism' in international relations' S. Hobden and J. M. Hobson (eds.) Historical Sociology of International Relations (Cambridge University Press, Cambridge, 2002), pp. 3 - 41.

Hoogensen, G. and Stuvóy, K. 'Gender, Resistance and Human Security' Security Dialogue Vol. 37, No. 2 (2006), pp. $207-228$.

Iloogensen, G. and Rottem, S. V. 'Gender Identity and the Subject of Security' Security Dialogue, Vol. 35 , No. 2, (2004), pp. $155-171$.

Horn, D. 'Setting the Agenda: US and Nordic Gender Policies in the Estonian Transition to Democracy' International Feminist Journal of Politics, Vol. 10, No. 1 (2008), pp. 59 - 77.

Howarth, D. Discourse (Open University Press, Buckingham, 2000).

Hrycak, A. 'Foundation Feminism and the Articulation of Iybrid Feminisms in Post-Socialist Ukraine' East European Politics and Societies Vol. 20, No. 1, pp. 69-100.

Hudson, H. 'Doing' Security As Though Humans Matter: A Feminist Perspective on Gender and the Politics of Human Security' Security Dialogue Vol. 36, No. 2 (2005), pp. 155 - 74.

Hughes, D. 'Women in Black Against War in Yugoslavia' Eeminista! An Online Journal of Feminist Construction, Vol. 3, No. 1, http://wnw.feminista.com/archicves/v3n/hughes.heml [accessed 23 December 2005. No longer available].

Hutchings, K. Time and World Politics: Thinking the Present (Manchester University Press, Manchester, 2008).

Hutchings, K. '1988 and 1998: Contrast and Continuity in Feminist International Relations' Millennium: Journal of International Studies, Vol. 37, No. 1 (2008) pp. 97-105. 
Hutchings, K. 'Happy Anniversaryl Time and Critique in International Relations Theory' Revien of International Studies, Vol. 33, Special Issue (2007), pp. $71-89$.

Hutchings, $\mathrm{K}$.The Personal is International: Feminist Epistemology and the case of international relations' in Knowing the Difference: Feminist Perspectives in Epistemology (eds) K. Lennon and M. Whitford (London, 1994), pp. 149-63.

Huysmans, J. Revisiting Copenhagen: Or, On the Creative Development of a Security Studies Agenda in Europe' Eumpean Joumal of International Relations Vol. 4, No. 4 (1998), pp. 479 - 505.

Huysmans, J. 'Security! What Do You Mean? From Concept to Thick Signifier' European Journal of International Relations Vol. 4, No. 2 (1998), pp. $226-255$.

IANSA What is IANSA?' hupi//www.jansa.org/abouthtm [accessed 22 January 2010].

IANSA 'UN Security Council Open Debate on 1820 (2008)' [accessed 26 August 2008].

IANSA 'Disarming Domestic Violence' hup://www.iansa-womcn.org/disarm dv [accessed 26 August 2009].

IANSA Women in the Crossfire: UNSCR 1325 and Small Arms' Factsheet retrieved from www.junsilorg/women/ [accessed 26 August 2009].

Ignjatović, T. and Macanović, B. 'Impact on the Policy Making Process' report retrieved from www, womennge.ss [accessed 10 July 2009].

Incest Trauma Centre 'Announcement' regarding Women's Human Rights Defenders Summit' (2007) hutpi//www.incestramacentar.org.ju [accessed 10 November 2008 and no longer available].

Jacoby, T. 'From the Trenches: dilemmas of feminist IR fieldwork' B. A. Ackerly, M. Stern and J. True (eds.) Feminist Methodologies for Intermational Relations (Cambridge University Press, Cambridge, 2006), pp. 153-73.

Jarvis, L. Times of Termor. Discourse, Temporality and the War on Termor (Palgrave, Basingstoke, 2009). 
Jancar, B. 'The New Feminism in Yugoslavia' in P. Ramet Yugoslavia in the 1980s (Boulder, Colorado, 1985), pp. $201-220$.

Jenkins, K. Re-thinking History (Routledge, London, 1991).

Joachim, J. 'Shaping the Human Rights Agenda: The Case of Violence against Women' in M. K. Meyer and E. Prügl (eds.) Gender Politics in Global Governance (Rowman and Littlefield, London, 1999), Pp. $142-160$.

Johnson, J. E. Gender Violence in Russia: The Politics of Feminist Intervention (Indiana University Press, Bloomington, 2009).

Jolly, R. and Basu-Ray, D The Human Security Framework and National Human Development Reports (UNDP Occasional Paper 5, New York, 2006).

Kaldor, M., Martin, M. and Selchow, S. 'Human Security: A New Strategic Narrative for Europe' International Affuirs Vol. 83, No. 2 (2007), pp. 273 - 288.

Kant, I. 'Perpetual Peace: A Philosophical Sketch' in C. Brown, T. Nardin and N. Rengger (eds.) International Relations in Political Thought: Texts from the Ancient Greeks to the First World W'ar (Cambridge University Press, Cambridge, 2002), pp. 432-39.

Kaufman, J. P and Williams, K.P. Who Belongs? Women, Marriage and Citizenship: Gender Nationalism and the Balkan Wars' International Feminist Journal of Politis, Vol. 6, No. 3 (2004), pp. 416 435.

Keck, M. E. and Sikkink, K. Activists Beyond Boarders: Advocay Networks in Intermational Politics (Cornell University Press, Ithaca and London, 1998).

Keohane, R. O. and Martin, L. L. The Promise of Institutionalist Theory' Intermational Security, Vol. 20, No. 1 (1995), pp. $39-51$.

King, G. and Murray, C. L. 'Rethinking Iuman Security' Political Science Quarterly, Vol. 116, No. 4 (2001-2002), pp. 585- 610.

King, K. E. 'Method and Methodology in Feminist Research: What is the Difference?' Journal of Advanced Nursing, Vol. 20 (1994), pp. 19-22. 
Kvinna Till Kvinna To Make Room for Changes: Peace Strategies from Women's Organisations in Bosnia and Herzegovina (Kvinna Till Kvinna, Stockholm, 2006).

Korać, M. 'Gender, Conflict, and Peace-building: Lessons from the Conflict in the Former Yugoslavia' Women's Studies International Forum, Vol. 29 (2006), pp. 510 - 520.

Korač, M. 'Women organizing against Ethnic Nationalism and War in the Post-Yugoslav States', in W. Giles et al, Feminists Under Fire: Exchanges across War Zones (Between the Lines, Toronto, 2003) pp. 25-33.

Kosovo Women's Network (Reports) Monitoring Implementation of United Nations Security Council Resolution 1325 in Kosovo/a (Pristina, Kosovo/a 2007; (2 ${ }^{\text {nd }}$ ed.) 2009).

Krause, K. 'Critical Theory and Security Studies: The Research Programme of 'Critical Security Studies" Cooperation and Conflict Vol. 33, No. 3 (1998), pp. 298 - 333.

Krause, K. and Williams, M. C. 'Broadening the Agenda of Security Studies: Politics and Methods' in Mershon International Studies Review Vol. 40, No. 2 (1996), pp. 298 - 33.

Kulturni Centre DaMad, Novi Pazar, Project Report DPB 04-05/329/009 'Improving Women's IJuman Rights in Sandžak'. In author's possession.

Laclau, E. and Mouffe, C. Hegemony and Socialist Strategy: Towards a Radical Democratic Politics (Verso, London, 2001).

Lai, J. 'Situating Locations: The Politics of Self, Identity and "Other" in Living and Writing the Text' in S. Hesse-Biber and R. Lydenberg (eds.) Feminist Approaches to Theory and Methodology: An Interdisciplinary Reader (Oxford University Press, Oxford, 1999), pp. 100 - 37.

Laurance, E. and Stohl, R. Making Global Public Policy: The Case of Small Arms and Light Weapons Occasional Paper. No. 7 (Small Arms Survey, Geneva, December 2002).

Lilly, C. S. and Irvine, J. A. Negotiating Interests: Women and Nationalism in Serbia and Croatia, 1990 - 1997' East European Politics and Societies, Vol. 16, No. 16 (2002), pp. 109 - 144. 
Lind, A. Gendered Paradoxes: Women's Movements, State Restructuring, and Global Development in Ecuador (Pennsylvania State University Press, Pennsylvania, 2005).

Liotta, P. H. 'Boomerang Effect: The convergence of National and Human Security' Security Dialogue Vol. 33, No. 4 (2002), pp. $473-88$.

Lipschutz, R. D. (ed.) On Security (Columbia University Press, New York, 1995).

Litrichin, V. and Mladjenović, L. 'Belgrade Feminists: Separation, Guilt, and Identity Crisis' in T. Renne (ed.) Ana's Land: Sisterbood in Eastern Europe (Westview Press, Oxford, 1997), pp. 179 - 185.

Lukić, J., Regulska, J., Zaviršek, D. (eds) Women and Citizenship in Central and Eastern Eurppe (Ashgate, Aldershot, 2006).

Lukić, M. 'Domestic Violence - Legal Solutions and Institutional Treatment' in V. Nikolić-Ristanović (ed.) Women's Rights and Social Transition in the FRJ (Center for Women's Studies, Research and Communication, Belgrade, 1997), pp. $118-20$.

MacKenzie, M. 'Securitization and de-securitization: Female Soldiers and the Reconstruction of Women in Post-Conflict Sierra Leona' in L. Sjoberg (ed.) Gender and International Security: Feminist Perspectives (Routledge, London, 2009), pp. 151 - 167.

Manyard, M. and Purvis, J. (eds.) Researcbing Women's lives from a Feminist Perspective (Taylor and Francis, London, 1994).

Manyard, M. and Purvis, J. 'Introduction: Doing Feminist Research' in M. Manyard and J. Purvis (eds.) Researching Women's lives from a Feminist Perspective (Taylor and Francis, London, 1994), pp. 1 - 9.

Marcus, G. E. 'Ethnography in/of the world system: The Emergence of Multi-Sited Ethnography' Annual Review of Antbropology, Vol. 24 (1995), pp. $95-117$.

Marcus, I. 'Dark Numbers: Research on Domestic Violence in Central and Eastern Europe' in V. Nikolić-Ristanović (ed.) Women's Rights and Social Transition in the FRJ (Center for Women's Studies, Research and Communication, Belgrade, 1997), pp. 105 - 128.

Martin, M. and Owen, T. The Second Generation of Human Security: lessons from the UN and EU Experience' International Afuirs, Vol, 86, No. 1 (2010), pp. 211 - 224. 
Maruska, J. H. 'Feminist Ontologies, Epistemologies, Methodologies, and Methods in International Relations'. The International Siudies Encyclopedia. R. A Denemark (ed.) (Blackwell Reference Online, 2010) whw.isacompendium.com [accessed 30 March 2010].

Marx, K. and Engels, F. The Communist Manifesto (Oxford World Classics, Oxford, 1998).

Massey, G., Hahn, K., and Sekulić, D. 'Women, Men, and the "Second Shift" in Socialist Yugoslavia' in Gender and Society, Vol. 9, No. 3 (1995), pp. $359-79$.

Mayer, T. (ed.) Gender Ironies of Nationalism: Sexing the Nation (Routledge, London, 2000).

Mazur, A. G. Theorizing Feminist Policy (Oxford University Press, Oxford, 2002).

McIntosh Sundstrom, L. Funding Civil Society: Foreign Assistance and NGO Development in Russia (Stanford University Press, Stanford, California, 2006).

McLean, S. J., Black, D. R. and Shaw, T. M. (eds.) A Decade of Human Security: Global Governance and New Multilateralisms (Ashgate, Aldershot, 2006).

McLeod, L. 'Experience, Reflections and Learning: Feminist Organizations, Security Discourse and UNSCR 1325' in E. Svedberg and A. Kronsell (eds.) Making Gender, Making War. Violence, Military and Peacekeeping Pratices (forthcoming: Routledge).

Mearsheimer, J. J. 'Back to the Future: Instability in Europe after the Cold War' International Security, Vol. 15, No. 1 (1990), pp. 5 - 56.

Meier, V. Yugoslavia: A History of its Demise (Routledge, London, 1999).

Meyer, M. K. and Prügl, E. (eds.) Gender Politics in Global Governance (Rowman and Littlefield, London, 1999).

Meyer, A. G. 'Feminism, Socialism, and Nationalism in Eastern Europe' in Women, State, and Party in Eastern Europe (eds.) S. L. Wolchick and A. G. Meyer (Durham, 1985), pp. 13 - 30.

Milic, A. The Women's Movement in Serbia and Montenegro at the turn of the Millennium: A Sociological Study of Women's Groups' Feminist Review, Vol. 76 (2004), pp. 65 - 82. 
Milić, A. Nationalism and Sexism: Eastern Europe in Transition', in (eds) R. Caplan and J. Feffer Europe's New Nationalism: States and Minorities in Conflict (Oxford University Press, Oxford, 1926), pp. $169-183$.

Mills, P. Working to Promote 1325 in Israel: Opportunities and Challenges Facing Activist Women and Isha L'Isha' Paper presented to The Boston Consortium on Gender, Security and I Iuman Rights on November 29 2006, retrieved from http://www.genderandsccurity.org/mecring.htm] [accessed 10 February 2008].

Mladjenović, L. Women's Emotions and State Policies: A Women's Organisation Against Male Violence from a Counsellor's Perspective' paper given at the international conference 'Stop Domestic Violence against Women: Ten years of Austrian Anti-Violence Legislation in the International Context', Vienna, November 5- 62007.

Mladjenović, L. 'Autonomous Women's Centre against Sexual Violence, Belgrade: A Personal Story' www.womenngo.rs [accessed 16 June 2006].

Mladjenović, L. 'Feminist Politics in the Anti-war Movement in Belgrade: To Shoot or Not To Shoot?' in W. Giles, A. de Alwis, E. Klein and N. Silva Feminists Under Fire: Exchanges across War Zone (Between the Lines, Toronto, 2003), pp. 157 - 166

Mladjenović, L. 'The Politics of Knowledge of Difference: Thoughts and Contradictions in Feminist Politics in the Anti-war Movement in Belgrade from 1991 to 1999' in Peaceworks, March 2000.

Mladjenović, L. and Matijašević, D. 'SOS Belgrade July 1993 - 1995: Dirty Strcets' in C. Corrin Women in a Violent World (Edinburgh University Press, Edinburgh, 1996), pp. 119 - 132.

Madjenović, L. and Litricin, V. (transcribed by T. Renne) 'Belgrade Feminists 1992: Separation, Guilt and Identity Crisis’ Feminist Review, No. 45 (1993), pp. 113 - 119.

Moravcsik, A. 'Taking Preferences Seriously: A Liberal Theory of International Politics' International Organization, Vol. 51, No. 4 (1997), pp. $513-53$.

Morgenthau, H. J. Politics Among Nations: The Struggle for Power and Peace (McGraw-I Iill, Boston, 1993).

Moser, C. and Moser, A. 'Gender Mainstreaming Since Beijing: A Review of successes and limitations in international institutions' Gender and Development Vol. 13, No. 2 (2005), pp. $11-22$. 
Molyneux, M., 'Analysing Women's Movements' in Feminist Visions of Development: Gender Analysis and Poligy (eds.) C. Jackson and R. Pearson (Routledge, London, 1998), pp. 65 - 87.

Molyneux, M., 'Mobilisation without Emancipation? Women's Interests, the State and Revolution in Nicaragua' Feminist Studies, Vol. 11 (1985), pp. 227 - 254.

Molyneux, M. 'Socialist Societies Old and New: Progress Towards Women's Emancipation?' in Feminist Review, No. 8, (1981), pp. 1 - 34.

Mršević, Z. 'Belgrade's SOS Hotline for Women and Children Victims of Violence: A Report' in S. Gal and S. Kligman (eds.) Reproducing Gender: Politics, Publics, and Everyday Life after Socialism (Princeton University Press, Princeton: New Jersey, 2000), pp. $370-392$.

Muggah, R. and Krause, K. 'A True Measure of Success? The Discourse and Practice of Human Security in Haiti' in S. J. Mclean, D. R. Black and T. M. Shaw (eds.) A Decade of Human Security: Global Governance and New Multilateralisms (Ashgate, Aldershot, 2006), pp. 113 - 126.

Muggah, R. and Berman, E. Humanitarianism Under Threat: The Humanitarians Impacts of Small Arms and Light Weapons Special Report (Small Arms Survey, Geneva, July 2001).

Neal, F. W. Yugoslav Communist Theory' in American Slavic and East European Review, Vol. 19, No. 1 (1960), pp. $42-62$.

Nelson, L. 'Bodies (and spaces) do Matter: The Limits of Performativity' Gender, Place and Culture: Journal of Feminist Geography Vol. 6, No. 4 (1999), pp. 331 - 53.

Newman, E. 'Critical Human Security Studies' Review of International Studies Vol. 36, No. 1 (2010), pp. $77-94$.

Newman, E. 'Hluman Security and Constructivism' in International Studies Perspectives Vol. 2 (2001), pp. 239-51.

Nikolic-Ristanović, V. and Dokmanović, M. International Standards on Domestic Violence and Their Implementation in the W'estern Balkans (Prometej, Belgrade, 2006).

Nikolic-Ristanović, V. Social Change, Gender and Violence: Post-Communist and war affected societies (Kluwar Academic Press, Dorsrecht, 2002). 
Nikolić-Ristanović, V. War and Post-War Victimization of Women' Eumpean Journal of Crime, Criminal Law and Criminal Justice, Vol. 10, No. $2-3$ (2002), pp. $138-145$.

Nikolić-Ristanović, V. 'Violence Against Women in Post-Communist Societies: Bencfits and Changes' Occasional Paper, East European Studies at the Woodrow Wilson International Center for Scholars (May 2001).

Nikolić-Ristanović, V. (ed.) Women's Rights and Social Transition in the FRJ (Center for Women's Studies, Research and Communication, Belgrade, 1997).

Nye, J. S. and Lynn-Jones, S. M. 'International Security Studies: A Report of a Conference on the State of the Field' International Security Vol. 12, No. 4 (1988), pp. $5-27$.

Obradović-Wochnik, J. 'Knowledge, Acknowledgement and Denial in Serbia's Responses to the Srebrenica Massacre' Journal of Contemporary European Studies, Vol. 17, No. 1 (2009), pp. 61 - 74.

Oberletiter, G. 'Human Security: A Challenge to International Law?' Global Governance Vol. 11 (2005), pp. $185-203$.

Occhipinti, L. 'Two Steps Back? Anti-feminism in Eastern Europe' Antbmopology Today, Vol. 12, No. 6 (1996), pp. $13-18$.

Ogata, S. 'State Security- Human Security' UNU Public Lectures Fridtjof Nansen Memorial Lecture, December 2001 (United Nations University, Tokyo).

Olick, J. K. The Politics of Regret: On Collective Memory and Historical Responsibility (Routledge, London, 2007).

Papić, Ž. 'Women in Serbia: Post-Communism, War, and Nationalist Mutations' S. P. Ramet Gender Politics in the Western Balkans: Women and Society in Yugoslavia and the Yugoslav Suctessor States (Pennsylvania State University Press, Pennsylvania, 1999), pp. 153-69.

Parashar, S. 'Women, militancy, and Security: the South Asian Conundrum' in L. Sjoberg (ed.) Gender and International Security: F'eminist Perspectives (Routledge, London, 2009), pp. 168 - 187. 
Paris, R. 'Human Security: Paradigm Shift or Hot Air?' in International Security Vol. 26, No. 2 (2001), pp. $370-3$.

Perkovic, M. 'From Rebellion to Alternatives' in Women in Black Women for Peace (Belgrade, 2007), pp. $22-5$.

Peterson, S. and Runyan, A. S. Global Gender Issues, (Westview Press, Boulder, 1999).

Programme of Action to Prevent, Combat and Eradicate the Illicit Trade in Small Arms and Light Weapons in All Its Aspects (UN Document A/CONF.192/15) http://www.poaiss.org/Po.tpoahtml.aspx [accessed 06 September 2010].

Porter, E. Peacebuilding: Women in International Perspective (Routledge, London, 2007).

Rai, S. M. and Waylen, G. Global Governance: Feminist Perspectives (Palgrave, Basingstoke, 2008).

Ramet, P. Yugoslavia in the 1980s (Boulder, Colorado, 1985).

Ramet, S. (ed.) Gender Politics in the Western Balteans: Women and Society in Yugoslavia and the Yugoslav Successor States (Pennsylvania State University Press, Pennsylvania, 1999).

Reardon, B. A. Women and Peace: Feminist Visions of Global Security (State University of New York Press, Albany: New York, 1993).

Redhead, R. Visual Representation in Amnesty International's 2004 Campaign 'Stop Violence Against Women" International Feminist Jourmal of Politics, Vol. 9, No. 2. (2007), pp. 218 - 238.

Rehn, E and Sirleaf, E. J. Women, War and Peace: The Independent Experts' Assessment on the Impact of Armed Conflict on Women and Women's Role in Peace-building (United Nations Development Fund for Women (UNIFEM), New York, 2002).

Renne, T. (ed.) Ana's Land: Sisterbood in Eastern Eumpe (Westview Press, Boulder, Colarando, 1997).

Renne, T. 'Disparaging Digression: Sisterhood in East-Central Europe' T. Renne (ed.) Ana's Land: Sisterbood in Eastern Europe (Boulder, 1997), p. 1 - 11. 
Richter, J. 'Evaluating Western assistance to Russian women's Organisations' in S.E. Mendelson and J. K. Glenn (eds.) The Power and Limits of NGOs: A Critical Look at Building Democracy in Eastern Europe and Eurasia (Columbia University Press, New York, 2002), pp. 54- 90.

Richter - Devroe, S., "Here, it's not about conflict resolution - we can only resist': Palestinian Women's Activism in Conflict Resolution and Non-violence Resistance' in N. Al-Ali and N. Pratt (eds.) Women and War in the Middle East (Zed Books, London, 2009), pp. 158 - 190.

Roberts, D. Human Insecurity: Global Structures of Violence (Zed Books, London, 2008),

Roman, D. 'Gendering Eastern Europe: Pre-Feminism, Prejudice, and East-West Dialogues in PostCommunist Romania' Women's Studies International Forum, Vol, 24, No. 1, (2001), 53 - 66.

Ruddick, S. Maternal Thinking: Towards a Politics of Peace (The Women's Press, London, 1989).

Rugova, I. Women, Peace and Security: Kosovo Women's $\Lambda$ ctivists Efforts to Implement UNSCR 1325 ' in N. Farmsworth, Through Women's Solidarity to a Just Peace: $A$ Report based on the Women's Peace Coalition Second Annual Conference (Pristina, 2007), pp. 45 - 6.

Sandglass Women's Organisation Udruženje žena Pešcanite (Sandglass Women's Organisation) Information booklet (BiM Graf, Kruševac, August 2005).

Schroeder, E. and Newhouse, L. Gender and Small Arms: Moving into the Mainstream Monograph No. 104 (2004) retrieved from www.iss.co.za, [accessed 24 November 2008].

Security Dialogue Special Section: What is 'Human Security'? Vol. 35, No. 3 (2004), pp. 345 - 87.

SEESAC 'Activity Report - AR/110: SEESAC Roundtable on Firearms and Domestic Violence Legislation, Belgrade, Serbia, 8 May 2008' (15 May 2008).

SEESAC 'SEESAC Activity Report AR/107: Firearms Possession and Domestic Violence in the Western Balkans: A Comparative Study of Legislation and Implementation Mechanisms' (10 December 2007).

SEESAC 'SEESAC Strategy for Gender Issues in SLAW Control and AVPP Activities' (21 June
2007). 
SEESAC 'Combating the Proliferation and Impact of Small Arms and Light Weapons' Stability Pact for South Eastern Europe Regional Implementation Plan (Revised 2006). Retrieved from http://www.seesac,org/about-seesac/1/ [accessed 6 September 2010]

SEESAC 'About SEESAC' retrieved from www.seesac.org/about-scesac/1/ [accessed 6 September 2010].

SEESAC 'Background' retricved from www.seesac.org [accessed 14 December 2009].

SEESAC 'Mission Statement' retrieved from www.sccsac.org/about [accessed 24 September 2009].

Shapiro, M. J. The Politics of Representation: Writing Practices in Biograpby, Photograpby, and Policy Analysis (The University of Wisconsin Press, Wisconsin, 1988).

Shaprio, M. J. 'Textualising Global Politics' in J. Der Derian and M. J. Shapiro (eds.) Intertextual/International Relations: Postmodern Readings of World Politics (Lexington Books, New York, 1989), pp. $11-22$.

Shepherd, L. J. (ed.) Gender Matters in Global Politics: A Feminist Introduction to Intermational Relations (Routledge, London, 2010).

Shepherd, L. J. Gender, Violence and Security (Zed Books, London, 2008).

Shepherd, L.J. Power and Authority in the Production of United Nations Security Council Resolution 1325' Intermational Studies Quarterly Vol. 52, No. 2 (2008), pp. 383 - 404.

Shepherd, L. J. 'To save succeeding generations from the scourge of war': the US, UN and the violence of security' Review of International Siudies Vol. 34, No. 2 (2008), pp. 293 - 311.

Shepherd, L. J. 'Victims, Perpetrators and Actors' Revisited: Exploring the Potential for a Feminist Reconceptualisation of (International) Security and (Gender) Violence' British Journal of Politics and International Relations Vol. 9, No. 2 (2007), pp. 239 - 56. 
Shepherd, L. J. 'Veiled Reference: Constructions of Gender in the Bush Administration Discourse on the Attacks on Afghanistan Post-9/11' International Feminist Journal of Politics, Vol. 8, No. 1 (2006), pp. $19-41$.

Shepherd, L. J. Loud Voices Behind the Wall: Gender Violence and the Violent Reproduction of the International' Millennium Journal of International Studies Vol. 34, No. 2 (2006), pp. 377 - 401.

Sjoberg, L. (ed.) Gender and International Security: Feminist Perspectives (Routledge, London, 2009).

Sjoberg, L. 'Introduction' L. Sjoberg (ed.) Gender and International Security: Feminist Perspectives (Routledge, London, 2009), pp. 1-14.

Skeggs, B. 'Situating the Production of Feminist Ethnography' in M. Mayard and J. Purvis Researthing Women's Lives from a Feminist Perspective (Taylor and Francis, London, 1994), pp. $72-92$.

Skjelsbák, I. 'Traditions and Transitions: Perceptions of 'Good Womanhood' Among Twenty Bosnian Focus Group Participants' International Feminist Journal of Politics, Vol. 11, No. 3, (2009), pp. $392-411$.

Slapsak, S. 'Between the Vampire Iusband and the Mortal Lover: $\Lambda$ Narrative for Feminism in Yugoslavia' in Research on Russia and Eastern Europe, Vol. 2 (1996), pp. 201 - 225

Smith, S., Booth, K., and Zalewski, M. Intemational Theory: Positivism and Beyond (Cambridge University Press, Cambridge, 1996).

Snow, D. and Benford, R. 'Master Frames and Cycles of Protest' in A. D. Morris and C. M. Mueller (eds.) Frontiers in Social Movement Theory (Yale University Press, New Ilaven and London, 1992), pp. $138-155$.

Snow, D., Rochford, E., Worden, S., and Benford, R. 'Frame Alignment Processes, Micromobilization and Movement Participation' American Sociological Review, Vol. 51, No. 4, (1986), pp. $464-481$.

Social Innovations Fund http://wwww.sif.minrzs,gov.rs/ [accessed 8 December 2009]. 
Sperling, V. Organising Women in Contemporary Russia: Engendering Transition (Cambridge University Press, Cambridge, 1999).

Squires, J. The New Politics of Gender Equality (Palgrave, London, 2007).

Stanley, L. 'Methodology Matters!' in V. Robinson and D. Richardson (eds.) Introducing Women's Studies (Palgrave, Basingstoke, 1997), pp. 198 - 219.

Stanley, L. 'Feminist Praxis and the Academic Mode of Production: An Editorial Introduction' in Feminist Praxis: Research, Theory and Epistemology in Feminist Sociology, (ed). L. Stanley, (Routledge, London, 1990) pp. 3 - 19.

Stanley, P. 'Reporting of Mass Rape in the Balkans: Plus ca change, plus c'est la meme chose? From Bosnia to Kosovo' in Civil Wars Vol. 2, No. 2 (Summer 1999), pp. 74-110.

Steans, J. Gender and International Relations (Polity, London, 2006).

Stern, M. 'Racism, sexism, classism, and much more: reading security-identity in marginalized sites' in B. A. Ackerly, M. Stern, and J. True Feminist Methodologies for International Relations (Cambridge University Press, Cambridge, 2006), pp. 174-97.

Stern, M. Naming Security - Constructing Identity: 'Mayan-women' in Guatemaita on the eve of Peace' (Manchester University Press, Manchester, 2005).

Stiglmayer, A. (ed.) Mass Rape: The War against Women in Bosnia-Herzegovina (University of Nebraska Press, Lincoln, 1994).

Svedburg, E. and Kronsell, A. (eds.) Making Gender, Making War. Feminist Perspectives on Violence, Military and Peacekeeping Pratices (forthcoming; Routledge).

Sylvester, C. (ed.) Experiencing War (Routledge, London, 2011).

Sylvester, C. War, Sense, and Security' in L. Sjoberg Gender and International Security: Feminist Perspectives (Routledge, London, 2009), pp. 24 -37. 
Sylvester, C. 'Review of L. J. Shepherd Gender, Violence and Security: Discourse as Practice' Minerva: Journal of Women and War Vol. 3, No. 1 (2009), pp. $94-96$.

Sylvester, C. Conference: Touching War htp://www.lancs.ac.uk/fiss/cvents/touchingwar/ [accessed 2 December 2010].

Sylvester, C. Feminist International Relations: An Unfinished Journey (Cambridge, Cambridge University Press, 2002).

Sylvester, C. 'The Contributions of Feminist Theory' in International Theory: Positivism and Beyond (eds.) S. Smith, K. Booth and M. Zalewski (Cambridge University Press, Cambridge, 2002), pp. 254 278.

Sylvester, C. Feminist Theory and International Relations in a Postmodern Era (Cambridge University Press, Cambridge, 1994).

Sylvester, C. 'Riding the Hyphens of Feminism, Peace, and Place in Four- (or More) Part Cacophony' Alternatives: Social Transformations and Iumane Governance, Vol. 18, No. 1 (1993), pp. $109-118$.

Tešanović, J. The Diary of a Political Idior: Normal Life in Belgrade (Cleis Press, San Francisco, 2000).

Tešanović, J. 'Kosovo' http://boinlosing.net/2008/02/17/jalsmina tesimovic-ko-1.hm] [Accessed 9 November 2010].

Tešanović, J. La Vitta e Bella' in Women in Black (eds.) W'omen's Side of Wor (Women in Black, Belgrade, 2008), pp. $370-372$.

Thomas, C. 'Global governance, development and human security: exploring the links' Third World . Quarterly Vol. 22, No. 2, pp. $159-75$.

Thomas, N. and Tow, W. T. 'The Utility of Security: Sovereignty and Humanitarian Intervention' Security Dialogue Vol. 33, No. 2 (2002), pp. 177 - 92.

Tickner, J. $\Lambda$. 'On The Frontlines or Sidelines of Knowledge and Power?' Intermational Sindies Revien Vol. 8, No. 3 (2006), pp. $383-95$. 
Tickner, J. A. 'Feminism meets International Relations: Some Methodological Issues' in B. A Ackerly, M. Stern and J. True (eds.) Feminist Methodologies for International Relations (Cambridge University Press, Cambridge, 2006), pp. 19-41.

Tickner, J. A. 'Feminist Responses to International Security Studies' Peace Review Vol. 16, No. 1 (2004), pp. $43-8$.

Tickner, J. A. Gendering World Politics: Issues and Approaches in the Post-Cold War Era (Columbia University Press, New York, 2001).

Tickner, J. A. You Just Don't Understand: Troubled Engagement between Feminists and IR Theorists' International Siudies Quarterly, Vol. 41, No. 4 (1997), pp. 611 - 32.

Tickner, J. A. Re-visioning Security' in International Relations Theory Today (eds.) K. Booth and S. Smith (Polity Press, Cambridge, 1995), pp. 175-97.

Tickner, J. A. Gender in International Relations: Feminist Perspectives on Including Global Security (Columbia University Press, New York, 1992).

True, J. and Mintrom, M. 'Transnational Networks and Policy Diffusion: The Case of Gender Mainstreaming' International Studies Quarterly Vol. 45, No. 1 (2001) pp. 27 - 57.

Tuchman, J. M. 'Redefining Sccurity' in Foreign Affairs Vol. 68 (1989), pp. 162- 177.

Ullman, R. 'Redefining Security' Intermational Security Vol. 8, No. 1 (1983) pp. 129 - 153

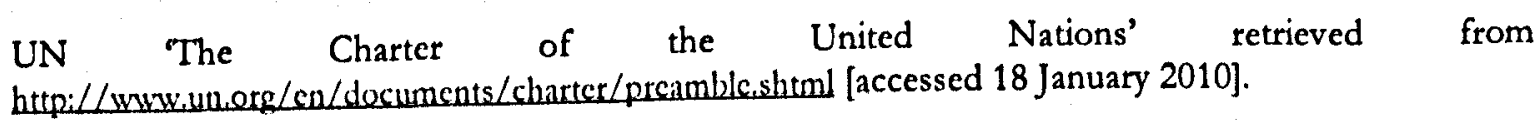

UNDP Crisis Prevention and Recovery Programme The Eight Point Agenda: Practical, Positive Outcomes for Girls and Women in Crisis' retrieved from hep://wwiv.undp.org/cpr/we do/8 pa.shtml [accessed 14 December 2009].

UNDP Human Development Report 1994: New Dimensions of Human Security (UNDP, New York, 1994). 
UNIFEM Country profile: Republic of Serbia (UNIFEM Regional Programme for Central and South-Eastern Europe) http://www.unifcm.sk [accessed 26 May 2009].

UNIFEM A Life Free of Violence Is Our Right! The UN Trust Find to End Violence Against W'omen 10 Years of Investment (UNIFEM, 2007).

United Nations Security Council Resolution 1889 (UNSCR 1889) 5 October 2009: S/RES/1889 (2009).

United Nations Security Council Resolution 1888 (UNSCR 1888) 30 September 2009: S/RES/1888 (2009).

United Nations Security Council Resolution 1820 (UNSCR 1820) 18 June 2008: S/RES/1820 (2008).

United Nations Security Council Resolution 1325 (UNSCR 1325) 31 October 2000: S/RES/1325 (2000).

Vaughan-Williams, N. Towards a Problematisation of the Problematisations that Reduce Northern Ireland to a Problem" Critical Review of International Social and Political Philosopby, Vol. 9, No. 4. (2006), pp. 513-26.

Victimology Society (Press Release) 'Manje Oružja u Kući-Manje Nasiljal Globalna Kampanja Bedeja Borbe Protic Basija Upotrebom Vatrenog Oružja' (Fewer Weapons at Home - Less Violencel Global Campaign Combating Violence Against Armed Weapons Weck) www.vols.orq.ju [accessed 26 August 2009].

Vuković, J. 'Security, The activities of Women in Black, and UN Security Council Resolution 1325' in Women in Black Women for Peace (Belgrade, 2007), pp. 182 - 6.

Vušković, L., Trivunac, S. 'Feministička grupa Žena i Društvo' (Feminist Group Women and Society) M. Blagojević (ed.) Ka Vidliivoj Żenskoj Istoriji: Zenski pokret « Beogradu 20-ib (Towards a Women's History: The Women's Movement in Belgrade in the 1990s) (Centar Za Ženske Studije, Beograde, 1998), pp. $47-60$.

Wrver, O. 'Securitization and Desecuritization' in R. D. Lipschutz (ed.) On Security (Columbia University Press, New York, 1995), pp. 46-86 
Walby, S. 'Gender Mainstreaming: Productive Tensions Theory and Practice' Social Politics Vol. 12, No. 3 (2005), pp. 321 - 343.

Waller, M. R. and Rycenga, J. (eds.) Frontline Feminisms: Women, War, and Resistance (Routledge, London, 2001).

Waltz, K. N. Man, the State, and War: A Theoretical Analysis (Columbia University Press, New York, 2001).

Waltz, K. N. Theory of International Politics (McGraw Hill, Boston, 1979).

Waylen, G. 'Transforming Global Governance: Challenges and Opportunities' in (eds.) S. M. Rai and G. Waylen Global Governance: Feminist Perspectives (Palgrave, Basingstoke, 2008), pp. 254-275.

Waylen, G. Engendering Transitions: Women's Mobilization, Institutions, and Gender Outcomes (Oxford University Press, Oxford, 2007).

Waylen, G. You still don't understand: Why troubled engagements continue between feminists and (critical) IPE' in Review of International Siudies, Vol. 32, No. 1 (2006), pp. 145 - 64.

Weber, C., 'Good Girls, Little Girls, and Bad Girls: Male Paranoia in Robert Keohane's Critique of Feminist International Relations' in Millennium: Joumal of International Studies, Vol. 23, No. 2. (1994) pp. $337-49$.

Weedon, C. Feminist Practice and Poststrutturalist Theory (Blackwell Publishing, Malden, MA, 1997).

Weldon, S. L. Protest, Poligy, and the Problem of Violence against Women: A Cross-National Comparison (University of Pittsburgh Press, Pittsburgh, 2002).

Wibben, A. T. R. 'Human Security: Toward an Opening' Security Dialogue Vol. 39, No. 4 (2008), pp. $455-62$.

Williams, P. 'Critical Security Studies' A. J. Bellamy (ed.) Intermational Society and its Critics (Oxford University Press, Oxford, 2005), pp. 135 - 50. 
Wolfreys, J. Deconstruction $\bullet$ Derrida (Macmillian, Basingstoke, 1998).

Women in Black (Published book) Žene za mir [Women for Peace] (Women in Black, Belgrade, 2009). In Serbian only.

Women in Black (Published book) Women's Side of War (Women in Black, Belgrade, 2008).

Women in Black (Published book) Women For Peace (Women in Black, Belgrade, 2007).

Women in Black (Published book) Women For Peace (Women in Black, Belgrade, 2004).

Women in Black (Published book) Women For Peace (Women in Black, Belgrade, 2001).

Women in Black (Published book) Women in Black, Women for Peace (Women in Black, Belgrade, 1996).

Women in Black (Published book) Women in Black, Women for Peace (Women in Black, Belgrade, 1995).

Women in Black (Published book) Women in Black, Women for Peace (Women in Black, Belgrade, 1994).

Women in Black (Published book) Women for Peace Anthology (Women in Black, Belgrade, 1993).

Women in Black (report) Women in Black Activities and Important Documents Related to the Implementation of the Resolution 1325' Report, March 2010. http://wnwiencucrnom.org [accessed 26 July 2010].

Women in Black (Film documentary) 'Women in Black 15 years on'. The film can be viewed on YouTube, with English subtitles.

http://www.youtube.com/results? search query $=W^{\prime}$ omen + in + Black + Scrbia\&esearch $=$ Search [accessed 5 December 2007].

Women in Black (Leaflet) "Femmes en Noir" Contre La Guerre' (Women in Black: Against the War) June 1992 in Compilation of information on crimes of war against women in ex-Yugoslavia (Women Living Under Muslin Laws, Montpellier, France, 1994), p. 55. 
Women in Black (Leaflet) Proclamation on the second anniversary of Women in Black' October 7 1993, Women in Black, Women for Peace (Women in Black, Belgrade, 1994), p. 17.

Women in Black (Leaflet) 'Women in Black Against War' 9 October 1991, Women For Peace Anthology (Women in Black, Belgrade, 1993), p, 22.

Women in Black (Leaflet) 'Women in Black against war' 10 June 1992, Women for Peace (Women in Black, Belgrade, 1993), p. 50.

Women in Black (Leaflet) 'We shall remain on the streets of Belgrade' 4 March 1997, Women for Peace (Women in Black, Belgrade, 1997), p. 24.

Women in Black (Press Release) 'Announcing a New Wave of Repression Against Women in Black' February 2007. http://unww,zencucrnom,org [accessed 11 December 2007].

Women in Black (Press Release) 'Announcement: Militarism, Nationalism and Sexism always go Together' 18 January 1995 in Women in Black, Women for Peace (Women in Black, Belgrade, 1995), p. 19.

Women in Black (Protest record) 'Reactions of Passers-by during our Protests. May 1997 - June 1998 ' in Women in Black, Women for Peace, (Belgrade, 1998), pp. 8 - 9.

Women in Black (Protest record) 'Our Silence is Visible' Women for Peace (Belgrade, 1996), p. 6.

Women in Black (Protest record) The Reactions of Passers-by to the Protest of The Women in Black' (1993) in Women in Black, Women for Peace, (Belgrade, 1994) pp. 12-14.

Women in Black (Public Statement) 'Draft Resolution' in Women for Peace (Belgrade, 2007), pp. 187 189.

Women in Black (Website) 'Our Mission' hetp://wnwwomcuinblack.net/mission.html [accessed 3 June 2010]. 
Women in Black (Website) Women's Feminist-Antimilitarist Peace Organisation' hrtp://www.zeneucrnom.org L [accessed 3 June 2010].

Women in Black (Website) 'We are Still on the Streets: Our 15 years' retrieved from http://www,zencucrnom.org/ [accessed 3 December 2007. The webpage has since been updated and the original is no longer available].

Women in Black (Workshop) 'Repression of Human Rights Defenders' 19 May 2007 Women in Black W'omen for Peace (Women in Black, Belgrade, 2007), pp. 208 - 211.

Women in Black (Workshop) 'Everything for Peace, Health and Knowledge, Nothing for Armament' May 2004 Women in Black Women for Peace (Women in Black, Belgrade, 2005), pp. 340 - 54.

Women in Black (Workshop) 'Meeting of Conscientious Objectors' 5 - 7 May 2000 Women in Black Women for Peace (Women in Black, Belgrade, 2001), pp. 241 - 2.

Women in Black (Workshop) 'Is there a specifically Female Pacifism?' Women in Black, Women for Peace (Belgrade, 1994), pp. 130 - 132.

Women in Black (Conference Report) 'Žene, mir, bezbednost: Rezolucija 1325, 30 i 31 oktobar 2008' [Women, Peace, Security: Resolution 1325, $30-31$ October 2008] in Zene za mir [Women for Peace] (Women in Black, Belgrade, 2009), pp. 215 - 241.

Women's Peace Coalition (Press Release) Women's Peace Activists from Kosova and Serbia agree on independence for Kosova' (Pristina/Belgrade, 5 September 2006). hitp://wwememedicamondialciory [accessed 8 December 2007].

Women's Peace Coalition, letter to President Martti Ahtisaari, UN Secretary General Envoy in Charge of the Negotiations on the Future Status of Kosovo (8 February 2007). http://www.zeneucrnom.org [accessed 29 November 2007].

Women's Peace Coalition (Leaflet) 'Women's Peace Coalition' May 2006.

Woolf, V. A Room of One's Own (Bloomsbury Classics, London, 1993). 
Wyn-Jones, R. 'Message in a Bottle'? Theory and Praxis in Critical Security Studies' Contemporary Security Poligy, 16, 3 (1995), pp. 299 - 319.

YUCOM (Report) 'Campaign to Promote UN Declaration on Human Rights Defenders in Serbia' (Belgrade 2009). Retrieved from http://wrww.rucom.org.ts/ [Accessed 28 November 2010].

YUCOM Public Files - Not To Be Forgotten: The Case of Civil Servant Aleksander Tijanic (YUCOM, Belgrade, 2004).

Yuval-Davis, N. Women and the Biological Reproduction of "The Nation"' Women's Studies International Forum, Vol. 19, No. 1 - 2 (1996), pp. $17-24$.

Žarkov, D. The Body Of War: Media, Ethnicity, and Gender in the Break-up of Yugoslavia (Duke University Press, Durham and London, 2007).

Žarkov, D and Cockburn, C. 'Introduction' in Cockburn, C. and Zarkov, D. The Postwar Moment: Militaries, Masculinities and International Peacekeeping (Lawrence and Wishart, London, 2002), pp. 9-21.

Zalewski, M. et. al. 'The Art of Crafting the Future-Present-Past' International Feminist Journal of Politics, Vol.11, No. 3 (2009), pp. $305-33$.

Zalewski, M. 'Do We Understand Each other Yet? Troubling Feminist Encounters With(in) International Relations' The British Journal of Politics and International Relations, Vol. 9, No. 2. (2007), pp. $302-312$.

Zalewski, M. 'Intervening in Northern Ireland: Critically re-thinking representations of the conflict' Critical Review of International Social and Political Pbilosopby, Vol. 9, No. 4 (2006), pp. 479 - 497

Zalewski, M. 'Gender Ghosts in McGarry and O'Leary and Representations of the Conflict in Northern Ireland' Political Studies, Vol. 53 (2005), pp. 201 - 221.

Zalewski, M. Feminism After Postmodernism: Theorising Through Practice (Routledge, London, 2000).

Zalewski, M. "Well, What is the Feminist Perspective on Bosnia?"' International Affairs, Vol. 71, No. 2, (1995), pp. 339- 356 . 
Zajović, S. Od Tradicionalnog do Feministilkog koncepta bezbednosti Rezolucija 1325 (On the Traditional to the Feminist Concept of Security: Resolution 1325) (Spektra, Belgrade, 2007).

Zajović, S. Transitional Justice: A Feminist Approach (Women in Black, Belgrade, 2007).

Zajović, S. Always Disobedient (Women in Black, Belgrade, 2007).

Zajović, S. Peace and Security from a feminist-pacifist Perspective' Women in Black Women for Peace (Belgrade, 2007), pp. 179-80. Also http://www.zeneucrnom.org [accessed 2 November 2007].

Zajović, S. 'Not in Our Namel' Talk given at Women's Peace Coalition Conference (1 - 3 September 2006, Struga, Macedonia). Reproduced in Women in Black Women for Peace (Women in Black, Belgrade, 2007), pp. $70-75$.

Zajović, S. 'Zene i militarizam u Srbiji' (Women and Militarism in Serbia) in Zene protiv rata (W'omen for Peace) (Belgrade, Women in Black, 1995), pp. 3-4.

Zajović, S. 'Birth, Nationalism and War' (Essay. 13 January 1995). Available at letpi//wwnw.hartfordhup.com/archives/62/0.39) html [accessed 9 August 2010].

Zehfuss, M. Constructivism in International Relations: The Politics of Reality (Cambridge University Press, Cambridge, 2002).

Zuckerman, E. and Greenburg, M. The Gender Dimension of Post-Conflict Reconstruction: An Analytical Framework for Policymakers' Gender and Development Vol. 12, No. 3 (2004), pp. 70 - 82.

Zukin, S Beyond Marx and Tito: Theory and Prattice in Yugoslav Socialism (Cambridge, Cambridge University Press, 1975).

The Role of Women in the Development of Socialist Self-Managing Yugoslavia: National Report of Yugoslavia on the Achievements in Promoting the Status and Role of Women during the UN Decade for Women (Belgrade, 1985).

----- Directory of Women's Groups in Serbia http://www.womenngo.org.ju/sajt/sait/english/sajt/women groups directorics/Srbija [last accessed 16 June 2006 and no longer available]. 
-.-.-PeaceWomen translations of UNSCR 1325

http://www.peacewomen.org/1325inTranslation/index.html [accessed 3 June 2010].

NAPs of UNSCR 1325 http//www.un-instraw.org/en/gps/gps-homepage/national-action-plans-onrcsolution-1325-html [Accessed 25 February 2010]. 